Universidad Nacional de La Plata

Facultad de Humanidades y Ciencias de la Educación

Secretaría de Posgrado

\title{
La poesía social de Juan L. Ortiz (1936-1946)
}

Tesis para optar por el grado de Doctor en Letras

Lic. Agustín Alzari

Director: Prof. Martín Prieto

Co-Director: Dr. Miguel Dalmaroni

Marzo, 2016 
Agradecimientos

Quiero agradecer en primer término a mi director, el profesor Martín Prieto. Su confianza y su extraordinaria percepción de la materia fueron claves en cada una de las sucesivas etapas de esta investigación, desde sus inicios hasta hoy. También a mi co-director, el doctor Miguel Dalmaroni, quien generosamente accedió a acompañarnos desde La Plata.

Agradezco a su vez a Nora Avaro y Daniel García Helder, críticos, escritores y editores, por sus valiosos aportes y sugerencias. $Y$ en el orden de los intercambios, al historiador Ricardo Pasolini, investigador de CONICET en la UNICEN, especialista en el tema y en el período, y con el cual mantuve todos estos años una productiva conversación epistolar que me permitió depurar y ajustar varias de mis hipótesis en lo que toca a la historiografía.

Quiero destacar, a su vez, la relevancia que tuvieron en esta investigación las instituciones que conservan y permiten el acceso libre a los materiales de archivo. Entre ellas: Biblioteca Nacional, CEDINCI, Biblioteca Argentina (Rosario) y Biblioteca Popular "Carlos Mastronardi» (Gualeguay). En cada una encontré estupendos profesionales y personas.

También, y muy especialmente, al CONICET, que me brindó la maravillosa posibilidad de dedicarme a investigar y difundir un tema que me apasiona.

A mis amigos Sebastián Bier, Florencia Castagnani, Matías Píccolo y Diego Giordano, con quienes comparto el gusto por la literatura argentina y la discusión política. A mi amiga y colega Lucrecia Radyk, que contribuyó con una traducción de "Les Plaines», de Emile Verhaeren.

Por último, quiero agradecer infinitamente a mi mujer, Ludmila Bauk. A ella y a nuestro pequeño hijo Vladimir, va dedicada esta tesis. 


\section{Indice}

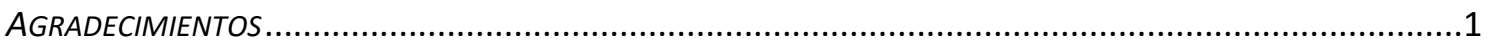

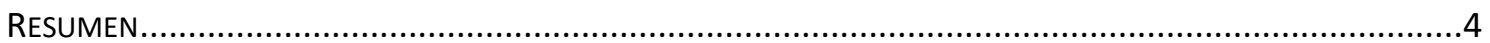

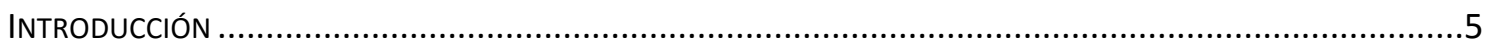

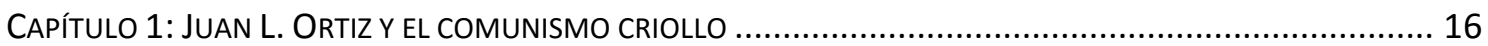

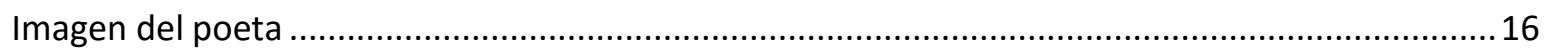

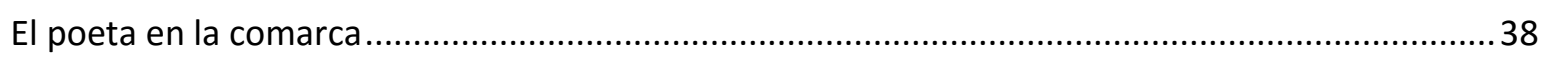

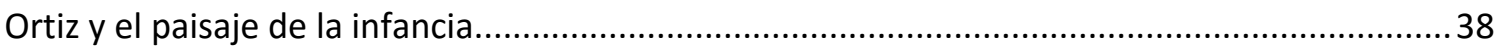

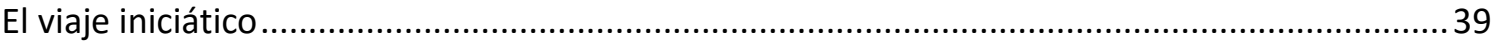

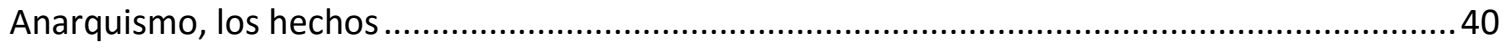

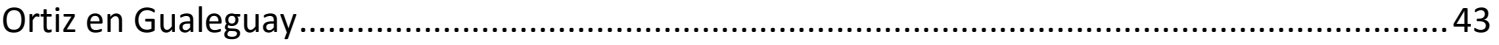

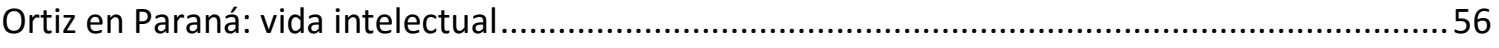

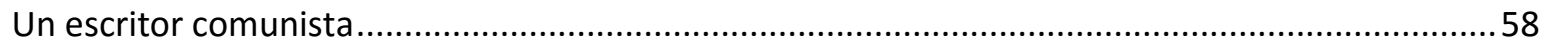

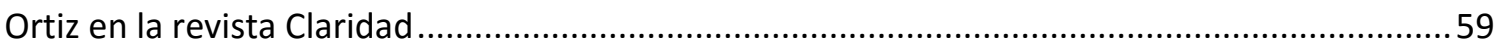

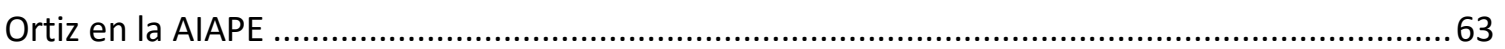

Ortiz en el Cancionero de la Guerra Civil Española..................................................................... 71

La revolución de Mayo y los deberes de la inteligencia ............................................................ 73

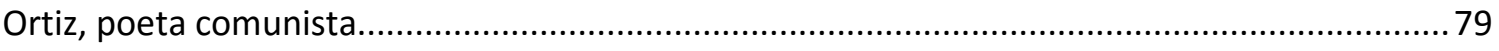

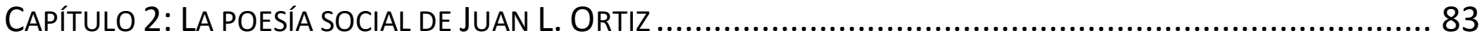

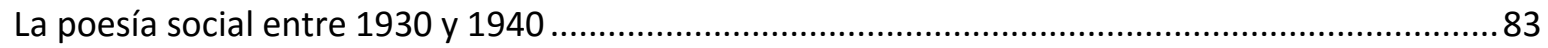

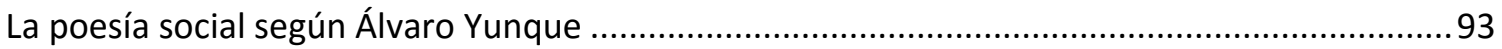

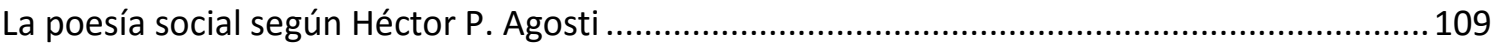

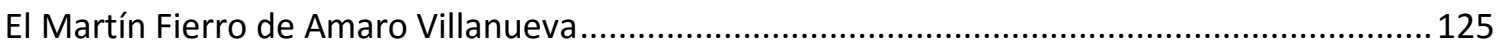

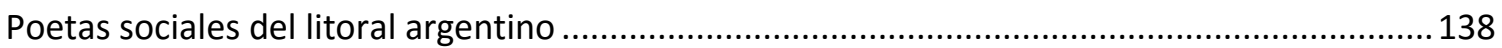

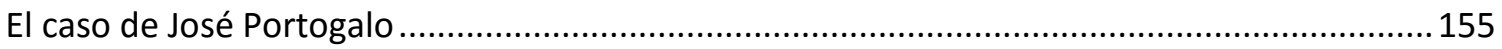

La poesía comunista internacional: Cesar Vallejo y Raúl González Tuñón ..................................166

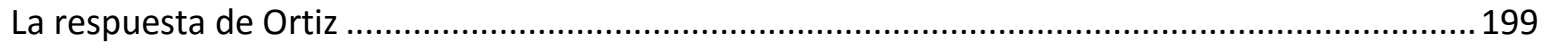

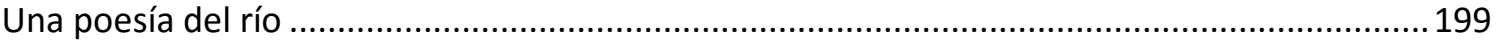

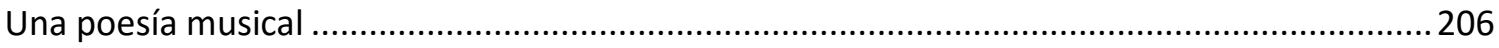

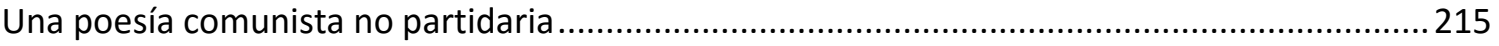

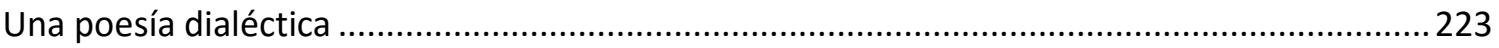

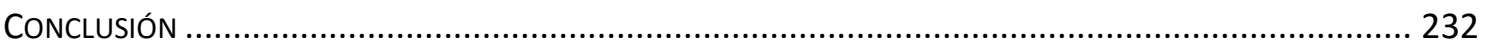

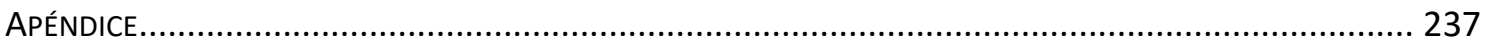

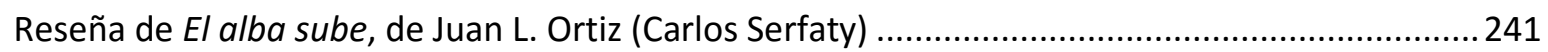


Poetas sociales de la Argentina. 1810-1943. (Selección) (Álvaro Yunque) .....................................244

«Visión del campo argentino» (Emma Barrandeguy) .....................................................................25

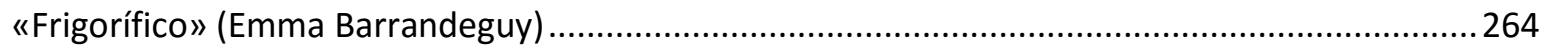

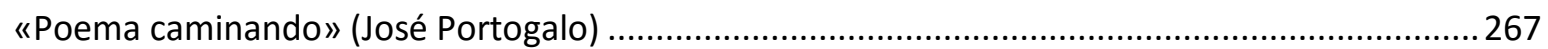

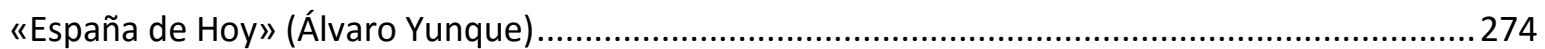

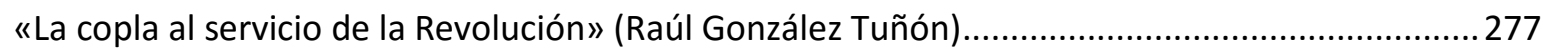

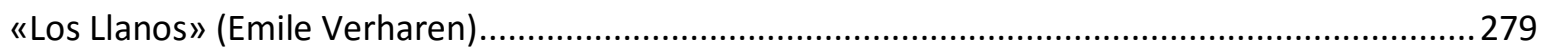

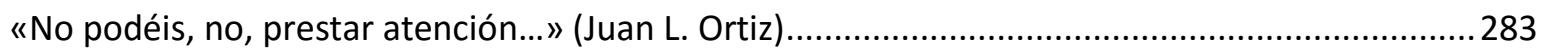

Memorias de un provinciano (Fragmento) (Carlos Mastronardi) ..................................................287

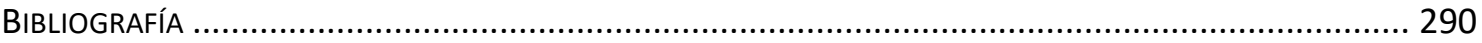




\section{Resumen}

En 1943, y de manera concluyente, Álvaro Yunque incluyó a Juan L. Ortiz en el selecto y reducido grupo de "Poetas Comunistas" que coronan los dos tomos de la antología Poetas sociales de la Argentina. Dicha ubicación representa un hito en la trayectoria de la figura y de la obra de Ortiz dentro de la sociabilidad comunista, y supone un contraste no solo con la imagen que se tiene hoy de él (un poeta aislado en su comarca, en las riberas entrerrianas) sino con los signos propios de su escritura evanescente y simbolista.

El primer capítulo de esta tesis, "Juan L. Ortiz y el comunismo criollo», incluye una exhaustiva revisión de publicaciones y testimonios tendientes a conformar un cuerpo documental que acredite dicho vínculo. Representa, a su vez, un ajuste no sólo en relación a su imagen de poeta, sino también a la circulación de sus poemas en el período.

El capítulo que le sigue, «La poesía social de Juan L. Ortiz», da cuenta de los nuevos horizontes que abre esta perspectiva y coloca su obra - específicamente la escrita entre los años 1936 y 1946 - en relación con la tradición de la poesía social en argentina, y, de manera puntual, con la tradición de los escritores e intelectuales vinculados al Partido Comunista Argentino, especialmente con los poetas José Portogalo, José Pedroni, Luis Gudiño Kramer, Emma Barrandeguy, Amaro Villanueva y Raúl González Tuñón, y con la producción crítica de Álvaro Yunque y Héctor Pablo Agosti.

Palabras clave: Juan L. Ortiz - poesía social - literatura argentina - Partido Comunista Argentino 


\section{Introducción}

La hipótesis principal de esta investigación data del año 2009, y forma parte del proyecto presentado en el ingreso al Doctorado de Letras de la UNLP. Allí se afirma que la obra de Ortiz establece, dentro del contexto de la «poesía social» posterior a Boedo, en Argentina, una respuesta efectivamente original al principal problema estético de la época, en el sentido de articular una obra que diga lo social, lo revolucionario, sin caer en el dogmatismo del realismo-socialista o algunas de sus variantes.

El ensayo en el que Héctor P. Agosti rescata el sentido político de la obra de Juan L. Ortiz, fechado en 1939, abre de manera significativa la serie de antecedentes con los que cuenta esta investigación. El destacado intelectual orgánico del Partido Comunista Argentino, incluye su ensayo sobre Ortiz dentro de un libro relevante para la historia de la crítica literaria argentina, como lo es Defensa del realismo (1945). Allí, la propuesta de un nuevo tipo de realismo que perciba el objeto y muestre en éste la tendencia al movimiento y a la transformación del mundo, encuentra una filiación con los libros publicados por Ortiz bajo el potente influjo que significaba para los artistas e intelectuales de izquierda la Guerra Civil Española. De los poemas incluidos en El alba sube (1937) y El ángel inclinado (1938), Agosti destacará la sinceridad de su enunciado poético y su profundidad ideológica. De manera contundente, dirá: «La esencia de su poesía está en el paisaje[...] Pero su trayectoria fundamental queda determinada por la conciencia del servicio social de la poesía» (Defensa del realismo 112). Ambos, el poeta y el intelectual comunista, comparten por aquellos años el espacio de la revista Nueva gaceta, órgano de difusión de la AIAPE (Asociación de 
Intelectuales Artistas Periodistas y Escritores), organización antiimperialista y antifascista en la que también milita Raúl González Tuñón. A este último, aunque Agosti no se detenga en detallar las confluencias y divergencias, le dedica el apartado que sigue al de Ortiz en Defensa del realismo.

La dificultad que implica unir la trayectoria poética de Ortiz con la tradición de la «poesía social» Argentina, queda graficada en el fascículo número 50 de Capítulo. La historia de la literatura argentina a cargo de Carlos Giordano (1967), cuyo título es «La poesía social después de Boedo». Allí, en columna aparte, bajo el ilustrativo título de «El caso de Juan L. Ortiz», Giordano traza una breve reseña del autor, y luego de los datos biográficos de rigor se apura en aclarar que su poesía «no es fácil de clasificar» ya que la «clave de su eficacia podría residir en la sorpresa que produce el descubrimiento (inevitable) de que esa evanescente y armoniosa poesía impresionista ha deslizado también un mensaje de lucha» (Giordano 1193). Es precisamente este aspecto el que interesa a Francisco Urondo (1971) de la poética de Ortiz: su capacidad de nombrar lo revolucionario sin las vestiduras del naturalismo. De manera más específica, María Teresa Gramuglio (2004) dirá que es posible visualizar el impacto de la política al interior de la estructura de ciertos poemas. Se manifiesta, según ella, en tres momentos o movimientos: un primer momento de dicha, de armonía, de plena integración entre poeta y paisaje, que viene a romperse con el adversativo «pero», marca de la irrupción de la injusticia social, de la guerra, de la división, y finalmente un tercer movimiento que convoca al anhelo de un orden superador, donde sean abolidas todas las diferencias (Gramuglio, Juan L. Ortiz 45-65). Este esquema es el primer análisis que se aventura al interior de la obra para intentar dar cuenta de esa relación en los términos de su propia poética. 
Tanto en el ensayo que acompaña la Obra Completa de Juan L. Ortiz (2005) editada por la Universidad del Litoral, como en el apartado «Poesía, política y paisaje en la obra de Juan L. Ortiz», dentro de su Breve historia de la literatura argentina (2006), Martín Prieto abre el abanico de relaciones para ubicar al poeta en el contexto de la historia de la poesía argentina. Allí toma relieve la relación de Ortiz con Raúl González Tuñón, a quien el entrerriano -destaca Prieto- admira y sugestivamente propone como «modelo de poeta». Si el ensayo de Gramuglio tienta una visión de lo político hacia el interior de su poesía, los trabajos de Prieto parecen realizar el movimiento inverso, sugiriendo posibles relaciones con otras obras contemporáneas.

En paralelo con la publicación de diversos ensayos derivados de esta investigación en revistas académicas, la aparición de las Obras Completas de Amaro Villanueva (2010) propició un avance significativo en el estudio de la escena de los escritores comunistas en Entre Ríos entre las décadas de 1930 y 1940. Específicamente a través de los ensayos «Entre Gualeguay y Paraná», de Claudia Rosa, y «El problema de la expresión nacional», de Daniel García Helder.

En el año 2012 se publicó la antología Estas primeras tardes y otros poemas para revolución, de Juan L. Ortiz, a través de Editorial Serapis de Rosario. El libro, de cuya edición estuve a cargo, concentra buena parte de los avances y documentación que hasta entonces había arrojado está investigación. La introducción - acompañada de documentos gráficosubica la figura de Ortiz en el universo de la poesía social y particularmente la poesía comunista. La sigue una selección de poemas organizados en dos grandes bloques: «Entre Ríos» y «Hacia el este (España, Rusia, China)», que traza un itinerario de su obra atendiendo a estos vínculos y permite notar esa constancia a través del tiempo, pues la antología toma la obra completa de Ortiz. Por último, en el apéndice se reproduce un relato inédito hasta 
entonces en libro, «Martín» (originalmente publicado en la revista Columna, № 9, 1937); dos cartas de Ortiz a Cesar Tiempo que se encuentra en el Archivo «Cesar Tiempo» de la Biblioteca Nacional; una carta a José Portogalo, conservada en el archivo familiar del hijo de este último, Pablo Ananía; y una serie de reseñas y recepciones de los libros de Ortiz en publicaciones vinculadas al PCA. Documentos que concurren a ubicar a Ortiz en el marco de la sociabilidad comunista.

El mismo año se publicó Tumulto, primera reedición del libro de poemas de José Portogalo, con ilustraciones de Demetrio Urruchúa, a través de editorial Serapis de Rosario. Estuve a cargo de la edición y de la investigación y escritura del prólogo. Los ejemplares del libro original, de 1935, habían sido secuestrados por orden del intendente de Buenos Aires, Mariano de Vedia y Mitre, en el momento de su salida. Tumulto es un libro agresivo y desprejuiciado, en lo que toca a la política, la religión y la sexualidad. La investigación realizada, que incluyó entrevistas a Pablo Ananía y un intenso rastrillaje en la hemeroteca de la Biblioteca Nacional, del CEDINCI y de la Biblioteca del Congreso Nacional en Buenos Aires, sitúa a Portogalo en el marco de la sociabilidad comunista. Era, además, amigo de Juan L. Ortiz, y pertenecían al mismo grupo de escritores de izquierda. El impulso de Tumulto puede vincularse al poema «Las brigadas de choque» de Raúl González Tuñón. Responde a la influencia de ciertos poetas norteamericanos como Langston Hughes y Carl Sandburg. La investigación y la publicación del libro permiten visualizar a Ortiz en el contexto de otras producciones poéticas de izquierda de la época que no sea la de Raúl González Tuñón. Se trata de un caso muy cercano. Por otra parte, el libro se había convertido en una verdadera rareza bibliográfica, por lo que su reedición (fiel a la original) contribuye a la circulación de un material rico y desconocido. 
Dos años más tarde, en 2014, publiqué una crónica en la serie naranja de la Editorial Municipal de Rosario, cuyo título es La internacional entrerriana. La información recogida en los fondos de la Biblioteca de Fomento Educacional de Gualeguay, en la provincia de Entre Ríos, de cuya Comisión Directiva formó parte Juan L. Ortiz, junto a Emma Barrandeguy y Carlos Mastronardi, entre 1935 y 1936, sumado al del Archivo de la Iglesia San Antonio de esa misma ciudad, y a la hemeroteca del Museo Histórico Provincial de Paraná, permitió reconstruir diferentes escenas de la vida pueblerina y de la participación directa de Ortiz tanto en la vida cultural (durante su gestión llegaron a Gualeguay, invitados por la Biblioteca Fomento, Raúl González Tuñón, Atahualpa Yupanqui, Cesar Tiempo y Felisberto Hernández, entre otros) como política de Gualeguay, así como en diversas polémicas que lo tuvieron como protagonista. El enfrentamiento con la Iglesia y los sectores conservadores, quienes acusaban a Ortiz y a sus compañeros de comunistas, confirma, en ese nivel doméstico (aunque luego la denuncia adquirió relieve nacional) sumamente rico en matices, la ubicación del poeta como militante. La edición del libro estuvo al cuidado de Oscar Taborda y Daniel García Helder. Este último es uno de mayores especialistas en la obra de Ortiz, y autor, a su vez, de "Juan L. Ortiz: un léxico, un sistema, una clave», uno de los ensayos fundamentales de la bibliografía crítica que se incluye en las sucesivas ediciones de la Obra Completa. La internacional entrerriana es una crónica de la investigación literaria llevada a cabo en Gualeguay en 2012 y, al mismo tiempo, una crónica de ciertos sucesos culturales ocurridos en ese mismo lugar en la década de 1930. Incluye una serie de fotografías de lugares y también de documentos inéditos y una gran cantidad de datos recogidos de cartas y periódicos de la época.

Estos tres libros - La internacional entrerriana, Tumulto y Estas primeras tardes y otros poemas para la revolución - pueden figurarse como desprendimientos de esta 
investigación que, de manera previsible dada su autonomía y lugares de publicación, generaron un espacio propio de escritura y circulación. Cabe indicarlos, por lo tanto, como antecedentes dentro del actual estado de situación. Sin embargo, la decisión metodológica es reelaborar, a favor de la escritura presente, tanto el material de fuentes como las hipótesis y recursos que se desarrollaron para hacer esos libros y artículos. De modo tal que no aparecerán citados, sino que son reescritos y utilizados de manera libre y fragmentaria para incorporarse de un modo orgánico al cuerpo mayor de la investigación representado por esta tesis.

Cabe resaltar el cambio en el período estudiado respecto del proyecto original: de la década de 1930-1940, se pasó a la que va de 1936 a 1946. Dicho corrimiento pone el foco en el período donde la producción y la circulación de la poesía Juan L. Ortiz se vincula de manera más directa con el universo comunista. No deja de ser curioso que, de manera coincidente, sea este el período de mayor producción cultural del Partido Comunista Argentino y del propio Juan L. Ortiz. Como poeta, como narrador y como intelectual militante, nunca produjo tanto en tan poco tiempo. En menos de cuatro años, publicó tres libros de poemas: El alba sube (1937), El ángel inclinado (1938) y La rama hacia el este (1940). Y las respuestas no se hicieron esperar: sus poemas y relatos aparecieron en las páginas de las principales revistas comunistas de la época. Sobre todo las dirigidas por Héctor P. Agosti, un cuadro cultural fundamental del PCA. Como ya se ha mencionado, Agosti le dedica a Ortiz una conferencia completa en el año 1939, acreditando, de manera inaugural aunque no por eso simplificadora, su ingreso a la tradición de la poesía comunista (H. P. Agosti, Defensa del realismo).

Este cambio del recorte temporal obedece, a su vez, a la idea de fijar una correspondencia entre la estrategia de Frentes Populares que adopta el PCA en ese período, 
y la presencia y circulación de la obra y figura de Juan L. Ortiz en aquel ámbito. Esta hipótesis vincular tiene la potencia de reponer, frente a la idea de que se trabaja sobre un caso aislado, la posibilidad de pensar el caso Ortiz en el contexto que brinda el cambio de estrategia del PCA, al pasar, en 1935, de la Lucha de Clases a los Frentes Populares. Ortiz vendría a ser, desde esta perspectiva, un punto más de una extensa red conformada por escritores, pintores, escultores e intelectuales cuya obra, a pesar de una intachable militancia personal, no habían tenido lugar de circulación dentro de la agresiva estética que imponía la estrategia de Lucha de Clases, y que, a partir de 1936, fecha en la que se asienta la nueva estrategia, comienzan a ser tenidos en cuenta. El examen de Tumulto, el libro de Portogalo publicado en 1935, es una licencia respecto al recorte temporal que apunta precisamente a subrayar, frente a Ortiz, el giro del PCA. Y el modo en que esto se relacionó con las estéticas que se ponían a circular o, mejor dicho, las que pasaron a legitimarse con el apoyo explícito de intelectuales orgánicos como el caso de Álvaro Yunque y Héctor Pablo Agosti. A partir del cambio de estrategia las conferencias de los intelectuales, los libros de prosa y poesía, los ensayos publicados en las revistas, las exposiciones de arte, funcionaron sobre la base de un estética no necesariamente partidaria, agresiva ni estrictamente militante, tal como lo demuestran las publicaciones de la AIAPE (Asociación de Intelectuales, Artistas, Periodistas y Escritores) cuyas actividades, además, estaban descentralizadas geográficamente respecto de Buenos Aires. En estos espacios culturales vinculados al PCA, se comenzó a dar lugar al matiz, a la diferencia.

Sobre la base de esta hipótesis es que resulta comprensible el mensaje de advertencia en la primera página de Un horizonte de cemento, la novela emblemática de Bernardo Kordon que publica la AIAPE en 1940, y dice: «NOVELA no es tesis, trama, retórica y toda máquina convencional de 50.000 palabras. NOVELA es lograr expresar la condición de 
aventura intensa y mágica de la existencia del hombre». La poesía de Ortiz, la obra gráfica de Leónidas Gambartes y la novela de Kordon, desmantelan, con su mera presencia en este ámbito, la imagen de un PCA rígido y esquemático, que impone a rajatabla el dogma del realismo socialista. No pueden pensarse como un conjunto de expresiones aisladas que excepcionalmente y por causas desconocidas encontraron lugar en el universo comunista, sino más bien como la manifestación de un estado de cosas.

Esta hipótesis no formaba parte de la serie inicial del proyecto. Surgió y cobró relevancia durante el proceso de investigación. Sobre todo al estudiar varios casos de escritores cercanos a Ortiz, como Emma Barrandeguy y José Portogalo; y también al cotejarlo con el más emblemático de los poetas comunistas argentinos: Raúl González Tuñón. Estos poetas propusieron desde su obra, entre 1933 y 1935, el ataque directo a las fuerzas burguesas. También el llamado a la revolución proletaria internacional. Allí están la arenga contra los estancieros y explotadores de los frigoríficos de Gualeguay en «Frigorífico», de Barrandeguy, en 1935 (Poesía Completa 60); el iconoclasta libro Tumulto, de 1935, que fue prohibido y sus ejemplares secuestrados, y le valió a Portogalo la deportación de Argentina; y el célebre poema «Las brigadas de choque», de Tuñón, que le costó una causa judicial y el cierre definitivo de la revista Contra. No se trata de nivelar estas apuestas estéticas, sino de dejar establecida una notoria diferencia con Ortiz, quien en 1933 publicó su primer libro, El agua y la noche, que no contiene ninguna clase de ataque a la burguesía, ni ningún llamado de ningún tipo a la acción del proletario. El agua y la noche es un libro dedicado al paisaje, donde apenas penetran, de manera velada y en pocos versos, el problema del hambre y el drama de la guerra. Lo cual lejos está de desmentir la militancia personal de Ortiz, en aquel año muy activo, acompañando precisamente a una jovencísima Emma Barrandeguy en una serie de actividades y campañas. Lo que se intenta clarificar es 
que la circulación y cierta consagración de Ortiz en el universo de los poetas comunistas se debe más a las consecuencias que trae en el campo cultural del partido el mencionado cambio de estrategia, que a un giro en la estética de Ortiz. Es cierto que los poemas que escribe entre 1936 y 1946 contienen, a diferencia de los publicados en El agua y la noche, referencias más o menos explícitas a la Guerra Civil Española, a la Unión Soviética y a la utopía de un futuro de prosperidad e igualdad. Pero la poesía de Ortiz no tuvo, ni tendría, proletarios, ni trabajadores, ni arengas. En toda su obra no se menciona siquiera una vez la palabra «comunismo». Sí, en cambio, aparecerá, en final del último verso de uno de sus más logrados poemas políticos de El alba sube (1937), "Estas primeras tardes...», una referencia que funcionará en el futuro como símbolo de pertenencia y la militancia:

La belleza de la tarde no sería recogida sólo por los árboles, por los pájaros, por el río que la lleva, hacia dónde? por un refinado nostálgico y ultrasensible, sino que tendría también una más amplia, inmediata, y por qué no? más completa expresión humana.

La tarde para todos, compañeros. (54)

«Compañeros» y «camaradas» se volverán desde entonces vocativos habituales en su poesía. Claros símbolos, al mismo tiempo, de pertenencia partidaria y de persistencia de una línea poética que disuelve toda posible aserción. No es Ortiz sino el PCA quien cambia bruscamente sus predicamentos estéticos. Es el PCA el que poner a circular una poesía social y revolucionaria de clave simbolista. Por supuesto, no sin roces y tensiones. Y el 
cambio, demás está decirlo, opera para el resto de los escritores y artistas comunistas. Portogalo, sin ir más lejos, se arrepentirá de por vida del corrosivo Tumulto, impidiendo sistemáticamente su reedición, y se vuelca, en el período que comprende esta tesis, hacia escritura de filiación postmodernista. Ese giro discursivo hacia la no agresión de las fuerzas políticas «democráticas» recibe la aprobación del PCA a través de la AIAPE, en cuyo sello Portogalo publica, en 1939, Canción para el día sin miedo.

La decisión de adoptar el período 1936-1946 tiene, a su vez, otra justificación. Dicha década representa, desde el punto de vista de la historiografía partidaria, no solo el apogeo de la estrategia de Frentes Populares, sino la etapa de máxima presencia del PCA en la política argentina, lo que incluye pero al mismo tiempo rebalsa el campo cultural. Situación que culmina, claro está, con la estrepitosa caída de la Unión Democrática de la que el PCA formaba parte, en la elección de 1946 ante Juan Domingo Perón.

En un terreno menos concluyente que el que brindan cifras, años y estrategias partidarias, se sitúa la hipótesis de que fue bajo la presión que se impuso en aquellos años a los escritores de izquierda o de fuerte compromiso político, que Ortiz forjó ciertos rasgos definitorios de su poesía. Rasgos que atraviesan la totalidad de su producción, desde aquellos poemas que sin dejar de ser notoriamente suyos patentizan contenidos militantes, como «Perdón joh noches!»; hasta otros donde lo revolucionario no representa un tema, como «Fui al río», sin dudas el poema más celebrado de su obra. Con «Fui al río», precisamente, abre Ortiz en 1937, en plena Guerra Civil Española, su tercer libro, El ángel inclinado. En ese libro tiene varios poemas con referencias a «camaradas» y «compañeros». Pero escoge «Fui al río» para la apertura. Una decisión que, puesta a operar en el campo específico de la poesía comunista argentina de aquel entonces, donde efectivamente 
circuló, se torna un extraordinario manifiesto sobre su manera de pensar la relación entre poesía y política.

A modo de cierre de esta introducción, interesa recordar brevemente el sistema de esta tesis. Está dividida en dos grandes capítulos. El primero de ellos, «Juan L. Ortiz y el comunismo criollo», pretende reponer un cuerpo documental que acredita a Ortiz como poeta comunista. Mientras que el segundo, "La poesía social de Juan L. Ortiz», dar cuenta de la perspectiva de «poesía social» que elabora el comunismo criollo a través de varios de sus más importantes escritores e intelectuales de la cultura, con la intención de percibir qué toma y qué aporta a esa tradición Juan L. Ortiz. 


\section{Capítulo 1: Juan L. Ortiz y el comunismo criollo}

Imagen del poeta

La novedad que supone en la imagen de Ortiz los datos sobre la sociabilidad comunista y los niveles de circulación de su obra en ese circuito entre 1936 y 1946 que se disponen a lo largo de este capítulo, representa quizás el aporte más significativo y original de esta investigación. Sobre todo en la alteración que supone frente a la imagen habitual y más extendida que se tiene, incluso hoy en día, del poeta.

Sin pretender realizar una historia exhaustiva de cómo Ortiz fue visto y retratado por periodistas, críticos, compiladores y estudiosos de su obra a lo largo del tiempo, corresponde, al menos, dar cuenta de cuál es la mentada «imagen habitual». Una hipótesis es que dicha imagen se forja entre las décadas de 1960 y 1970, es decir, en el último tramo de la vida del poeta, cuando ya se encontraba instalado en Paraná y era frecuentado por periodistas, poetas y escritores de Santa Fe, Rosario y Buenos Aires.

Por el peso que supone figurar en la «Introducción» a En el aura del sauce (1970), debe colocarse, en primer término, la imagen que brinda Hugo Gola:

Sorprende que en un país tan desvalido de grandes poetas su obra haya permanecido casi ignorada por antólogos y “entendidos" y marginada del cauce prestigioso de la "alta cultura" [...] Atrincherado en su fortaleza provinciana Ortiz no fue alterado por este olvido. Comulgó con las obras de la mejor literatura. Li Tai Po y Proust, Cummings y Maeterlinck, Rilke y 
Pasternak, Keats y Shelley, le ofrecieron su fraternidad iluminada, el arco visionario que lo sostuvo sin desgaste, permitiéndoles crear y crecer, construir sin mella la alta catedral de su poesía. Su aislamiento entonces se transformó en impulso y renunció a todo lo que no fuera el humilde y paciente trabajo con las palabras y la música, que lo unieron, al amparo del silencio, con las hojas, las hierbas y el río, que siempre fluye espejando los cambios del tiempo. (11)

Un año antes, en 1969, Juana Bignozzi publicó en Buenos Aires la primera antología de poesía de Ortiz, Juanele, poemas, a través de Carlos Pérez Editor. La profusión de errores en la transcripción de los poemas y prosas concitó el enojo del poeta, quien respondió con una solicitada en los diarios de Paraná: «Habiendo aparecido con el título de Juanele, poemas y bajo el sello de Carlos Pérez Editor, una selección de poemas y prosa de los que se me hace responsable, no me toca sino declarar que me resulta casi imposible reconocerme allí tras lo que ha quedado de las mutilaciones, de las trasposiciones de línea, de las sustituciones de palabras, de las alteraciones en la ortografía y en los espacios interlineado» (J. L. Ortiz 1104). Pasando a hablar, en la frase siguiente, de «"poemacidios" evidentes, sujetos, presumiblemente a sanciones».

Sin que entre en relación con el lamentable hecho que significó para la circulación de la poesía de Ortiz que la primer antología editada en Buenos Aires careciera por completo del rigor y de los atributos visuales del resto de sus libros, la operación que Bignozzi llevó a cabo como editora tiene una efectividad notable sobre la imagen del poeta, y es casi el lugar común que perdura entre sus lectores hasta el presente. Se transcribe, entera, la contratapa de dicho libro: 
Este poeta configura uno de los mitos del silencio de la literatura argentina. Su obra, editada con amor, en entregas casi misteriosamente personales, no quiso proyectarse a la notoriedad de las ediciones corrientes. Más que leído, nombrado el poeta del rio y la naturaleza minuciosa, organizó a su alrededor apenas un núcleo de iniciados. Este libro cumple la función ineludible de construir la comunicación de su mensaje poético a través de la primera antología de sus libros. (J. L. Ortiz, Juanele.Poemas)

Tamara Kamenszain refuerza esa imagen en una nota para el diario Clarín del 7 de junio de 1973:

Hace más de un año — cuando se presentó la obra en tres tomos de Juan L. Ortiz En el aura del sauce-, Buenos Aires supo que en las orillas del Paraná trabajaba desde hacía más de sesenta años, una de las voces poéticas más hondas y verdaderas del país [...] Entre 1915 y 1942 vive en Gualeguay trabajando como empleado del Registro Civil. En 1942 se radica definitivamente en Paraná — sale sólo en el 57, invitado a una gira por los países socialistas - en una modesta casa frente al parque Urquiza. Juanele se ha rodeado de gatos, de objetos largos y finitos - "me gustan, me recuerdan el espíritu chino" - como boquillas o pipas que él mismo se confecciona con cañitas que recoge a orillas del río.

En las coordenadas que forjan juntos los atributos de la soledad, el aislamiento, el refinamiento, el silencio, la mística de maestro e iniciados, la entrega al paisaje, se crea lo que Daniel Freidemberg (2001) llamó más tarde la «marca Juanele». Una imagen de poeta 
que al tomar el valor de mito para toda una generación funcionaba de manera independiente a la lectura de su obra.

La potencia que tiene esta imagen de poeta místico y aislado, impidió poner a jugar los efectivos datos que todos los autores citados - casi sin excepción - brindaron sobre la relación de Ortiz con el universo de la izquierda argentina. Aunque lo hicieran de manera vaga o imprecisa, desechando cualquier clase de vínculo partidario, es llamativo que no se haya prestado atención a ese hecho y no haya concitado, hasta el presente, un estudio específico. Edelweiss Serra (1976), quien publicó en Buenos Aires El cosmos de la palabra. Mensaje poético y estilo de Juan L. Ortiz - el primer libro dedicado enteramente a la obra y figura de Ortiz-, aporta datos biográficos que nadie recogió ni volvió a mencionar, como la vinculación de Ortiz con la actividad gremial y política en la izquierda entrerriana en la década de 1930:

El poeta, nacido en Puerto Ruiz (Entre Ríos) el 11 de junio de 1896, pasa su niñez en Villaguay y se radica luego en la ciudad de Gualeguay. A los diecisiete años vive una experiencia de bohemia en contacto con la cultura metropolitana. Pronto regresa a su Gualeguay, a su río y a sus islas: empleado del Registro Civil, todas sus horas libres las dedicará a la actividad poética y autodidacta. Incursionará en la acción sindical y política adherido a las tendencias de izquierda, por sobre todo entregando afanes a ideales de progreso social y cultural para el pueblo. En 1942 se jubila y se instala con su mujer e hijo en la ciudad de Paraná consagrándose enteramente al quehacer poético y de donde se moverá solamente en 1957 para integrar una delegación de intelectuales y artistas invitada a visitar los países socialistas, 
China y la Unión Soviética principalmente. Más importante que la posición en un partido, que un cargo público, que el llamado a ejercer funciones encumbradas, que títulos y honores - en realidad no los ha tenido o gozado en su larga existencia-, es su propia vida consagrada a la poesía y a su vocación irrenunciable al magisterio poético la forja personal de sí mismo. (Serra 120)

Otra es la imagen que, de manera casi programática, comenzó a trazar la generación de críticos y escritores que, nucleados varios de ellos inicialmente alrededor de Diario de Poesía, terminaron formando parte de la obra crítica que acompaña a la Obra Completa a cargo de Sergio Delgado, publicada en 1996 en la Universidad Nacional del Litoral. Martín Prieto, Daniel García Helder, Daniel Freidemberg y el propio Sergio Delgado, rompen con la imagen del poeta aislado y colocan a Ortiz como un referente de sucesivas generaciones de poetas. Hacia ese mismo rumbo apunta el trabajo de Alfredo Veiravé en el apartado biográfico de Juan L. Ortiz, la experiencia poética - cuyo antecedente es el temprano «Estudio Preliminar para una Antología de la Obra Poética de Juan Ortiz», publicado en el n 65 de la revista Universidad de la UNL, en 1965- y la introducción de Juan José Saer a la Antología de poemas de Ortiz publicada por UNL en 1989, cuyo título es «Juan»:

Me parece necesario hacer notar que, a partir de 1950, la significación del trabajo de Juan empieza a hacerse evidente en la poesía argentina ya que son raros los poetas de las nuevas generaciones que, cualquiera sean sus propias tendencias estéticas, no reconozcan en ese trabajo una referencia de primer orden. Juan ha sido uno de los pocos interlocutores de una generación anterior que, en razón de la persistencia de sus búsquedas, los poetas más 
jóvenes podían considerar como uno de sus contemporáneos. La visita a Juan L. a Paraná se transformó desde mediados de los años 50 en un ritual iniciático de la joven poesía argentina. Este hecho relativiza su marginalidad y lo pone más bien en el centro de la actividad poética de los últimos cuarenta años. (10-11)

Al mismo tiempo, los diversos trabajos que figuran en la Obra Completa, tanto el de García Helder como los de Gramuglio y Prieto, ofrecen la imagen de un poeta sensible al drama social. Este último afirma:

Esta poesía, que ligeramente llamamos "social" por sus asuntos y proyecciones, no debe sorprendernos en un autor que sentía una singular admiración por González Tuñón, uno de los "poetas sociales" argentinos más emblemáticos. “¿Quién da para usted la imagen de poeta?”, le pregunta Juana Bignozzi, y contesta Ortiz: “Raúl, ah, sí, siempre me ha parecido. Raúl González Tuñón". Si nos sorprende, en cambio, es porque lo que entendemos por "poesía social” en la Argentina, desde, justamente, Raúl González Tuñón en adelante, es una poesía de marcado tono urbano y Ortiz prefiere otro modelo, tan singular como el anterior, pero verdaderamente menos conocido. (117)

Junto con el aporte de Carlos R. Giordano, estos trabajos representan el antecedente inmediato y el punto de partida de esta investigación. Son ellos, principalmente, quienes remueven y ponen en cuestión la imagen ya por entonces fijada, establecida y extendida de Ortiz como un poeta místico, silencioso y aislado. Prescinden, eso sí, de todo dato de 
circulación o vínculo partidario concreto. La palabra comunismo, o Partido Comunista, no se menciona en lo absoluto en ninguno de esos estudios. De este conjunto de críticos y escritores solo Saer (1991) y Veiravé (1984) hacen alusión al respecto. Este último menciona la solidaridad de Ortiz con sus «compañeros de ruta» del Partido Comunista luego del golpe de estado de 1943 en un pasaje de Juan L. Ortiz. La experiencia poética (44); y Saer hace lo propio en El río sin orillas, al hablar de «una simpatía por el comunismo que no se desdijo hasta su muerte» (225-26). En ambos casos la referencia tiene un valor anecdótico.

Continuando este recorrido es factible reponer una imagen existente y luego olvidada de Ortiz: aquella que lo vinculó efectivamente a las ideas, a la militancia y a la sociabilidad comunista. Es llamativo como este conjunto de testimonios que siguen refieren, casi sin excepción, al período estudiado, comparten las coordenadas de la «imagen habitual» del poeta: el aislamiento, la entrega al paisaje, el refinamiento. Pero, no sin evidenciar en muchos casos la sorpresa, le suman otros atributos como la militancia comunista, el pensamiento acerca de la función social de la poesía, etc.

Tres indicaciones de rigor preceden a estas citas.

La primera es una somera descripción de sus autores: tanto Carlos Mastronardi, como Emma Barrandeguy forman parte de su entorno en Gualeguay. Mastronardi, reconocido escritor vinculado a la revista Martín Fierro, fue además uno de sus grandes amigos y el promotor de la publicación del primer libro de Ortiz, El agua y la noche, en 1933. Emma Barrandeguy, por su parte, pertenece a una generación más joven que ambos, pero comparte con Ortiz, a diferencia de Mastronardi, la militancia por la causa comunista. Juan José Manauta, escritor también gualeyo y más joven aún que Barrandeguy, no formó parte de la escena que vincula a Ortiz con los anteriores en la década de 1930, pero sí lo frecuentaría con posterioridad. Carlos Serfaty, Raúl Larra y Héctor P. Agosti son escritores y 
críticos porteños que pertenecen, en un sentido amplio, a la sociabilidad comunista en la que estaba inmerso Ortiz. Serfaty es un poeta no muy conocido que perteneció originalmente al grupo de Boedo (es quien, de buena fe y con una torpeza absoluta, termina con el misterio de la escritora proletaria Clara Beter - autora apócrifa de los Versos de una... - enviando aquel libro al Concurso Municipal de Buenos Aires con el nombre de su autor real, es decir, Cesar Tiempo). Raúl Larra es uno de los escritores centrales de la época vinculado al Partido Comunista Argentino, y, por último, Agosti uno de los principales intelectuales orgánicos del Partido.

La segunda indicación tiene que ver con las fechas. Si bien las referencias se ajustan, tal como se aclaró en la página anterior, casi por completo al período estudiado, no todas fueron producidas entre esos años. Los años de producción de cada fragmento se indican, por este motivo, en un lugar destacado: entre paréntesis y a espacio seguido del autor.

La tercera indicación tiene que ver con la extensión de las citas, que exceden, por mucho, lo usual para este tipo de estudios. La excepción tiene no se justifica solo en la originalidad y rareza del material expuesto (en el Apéndice hay otros casos de ese mismo tenor), sino en la intención de componer - a través de las diferentes escrituras de estos protagonistas - una imagen el poeta que funcione como referencia para el resto de esta tesis, centrada en la década comprendida entre los años 1936 y 1946. De allí su jerarquía y la decisión de incorporarlos al cuerpo central de la misma.

Carlos Mastronardi (1967, 1932 y 1935):

Si bien me veía ante un futuro borroso, la amable cercanía de Ortiz me agració aquel tiempo y, además, encontraba eventual expansión en las 
alternativas de una campaña a la cual me sumé y que se vinculaba con el gobierno de la biblioteca, entidad a cuyo dominio aspiraban los feligreses del cura párroco. Esa curiosa pugna, en la que intervinieron los periódicos locales, no careció de matices humorísticos. Ya dije cómo se originó y cuál fue su desenlace. Sólo quiero agregar que uno de nosotros daba la réplica en versos octosilábicos a cuyo pie se leía Fray Soviet. (Memorias de un provinciano 166)

Ortiz sale en estos días para esa Capital, de modo que omito detalles sobre su vida y obras. Creo, eso sí, que tanto sus (de Ud.) reiteradas invitaciones al urbanismo, como mi vieja oposición a su "geologismo" de tinte panteísta y oriental, han producido algún efecto en el espíritu de este buen amigo, el cual, ahora está en trance de análisis y de revisión total de sus antiguas, inmediatas tendencias y aceptaciones personales. El cimbronazo íntimo ha sido grande y, no obstante la geometría rígida que él advierte en la ciudad, comprende que ésta es indispensable -tanto como los viajes- en la formación literaria de cualquier hombre de nuestro tiempo. En efecto, corren zeitt (sic) de poesía culta y trabajada, no de poesía trovadoresca, reportista o agreste. No es necesario adherir a la decadencia legislada por Spengler para estar al cabo del esencial criticismo de nuestra época. La ciudad aguza nuestras facultades críticas, en tanto que la provincia solo culmina en lectores pasivos, aceptadores, asemejados -gástricamente- al avestruz. Por lo demás, el comunismo, que nuestro amigo bienquiere, supone una cuantiosa vida gregaria y una intensa complejidad industrial, que de ningún 
modo se compadecen con el éxtasis vegetal, el desdén por el urbanismo y la soledad intemporal: monopolios íntimos de nuestro excelente Ortiz. De todos modos, yo lo veo más animado y dinámico. La edición de su libro hará lo demás. Un más frecuente contacto con B.A. y con los amigos que tiene en B.A., acabará por extirpar su evanescente acuarelismo poético y sus mediostonos simbolistas, dolencias que afectan más de una página valiosa de este buen camarada. Entonces, podrán aflorar, con toda anchura, su flechera sensibilidad y su caridad mundial, su enternecido cosmos y su entresueño místico, cualidades, estas, que son triunfos de su pluma y puntos cardinales de su poesía. (Carta a Cesar Tiempo. 15 de Septiembre de 1932)

A propósito de visitas gratas, debo decirle que en la pasada semana lo tuvimos a R. G. Tuñón, quien nos habló sobre la nueva España y sobre el Congreso de Escritores celebrado en Paris el año pasado. La apasionada palabra de Raúl, y su entusiasmo revolucionario en especial, motivaron algunas protestas tilingas. Beracochea (padre) bruloteó a la Comisión de la Fomento, integrada por un hijo suyo, que Ud. conoce, por Ortiz y por mí, entre otros. Yo, que no soy comunista, escuché a Raúl sin remilgos y con agrado esencial. No practico su literatura (pragmática y nada gratuita) pero reconozco en su tono el tono de nuestro tiempo, tan apetente de graves mensajes como de majestuosas profecías. Advierto un cambio fundamental en la manera de ser de R. G. T. Lo encuentro más aplomado y maduro, más adicto a la entonación nostálgica que al libre juego verbal de sus años de café, cuando oscilaba entre Oyhanarte y la cocaína. En suma, puedo afirmar 
que en Gualeguay - ya a la vuelta de muchos años - he conocido otro R. G.

T. Me alegró ese descubrimiento. Por lo visto, nuestra generación ya concentra recuerdos, ya posee un acervo de tiempo sentido. Con respecto a la página literaria de Justicia que dirige la tímida y granulosa Emma Barrandeguy, le diré que, en mi concepto, puede usted colaborar sin que lo manes de la Casa del Pueblo le descarguen sus fuegos punitivos. Bromas aparte, y desconociendo sus puntos de vista políticos, le diré que dicha página no compromete la libertad de su presunto credo, no obstante tratarse de una página donde lo rojo se disimula malamente. Quiero decir que una publicación de esa índole, en Provincias, nunca asume un carácter netamente combativo y polémico, sino que, por lo general, se demora en lo expositivo y en cierta liviana didascalia de contornos románticos. Esa hoja de Justicia, tan tímida como su directora, combate de conjunto, la moral burguesa, la himenolatría y el latifundio [...] Por lo demás, el comunismo, por estos pagos, no pasa de una corazonada que aún no asume formas concretas. El ambiente hostil y la excesiva fiscalización propia de las colectividades pequeñas traban su acción. Además, falta capacidad de sacrificio y no existe ese desprendimiento heroico y total que las posiciones ideológicas extremas suelen reclamar. Excepción hecha de Ortiz -cuya fácil y natural adecuación a todas las formas de la santidad no me cansaré de alabar- no existen fervores totales dentro del bermejo movimiento local. No dudo de la sinceridad de los demás, pero sospecho no poseen fortaleza moral, vale decir, vocación para el sacrificio. (Carta a Cesar Tiempo. 16 de junio 1935) 
Juan José Manauta (1997):

Yo le habla acercado mis primeros poemas. Entonces él era un hombre que no hacía muchas críticas, en fin... leía con simpatía. Ahora, pensándolo bien, hubiese querido que fuera más rígido, más severo, conmigo. Pero, creo que era igual con Veiravé, el otro poeta que estaba en Gualeguay y que le llevó sus primeros poemas. Él nos leía, era una delicia, todos sus poemas, recién sacados del horno. Además, tenía la humildad de recibirnos, a unos imberbes, pero igual nos leía, con respeto, y esperaba nuestra opinión, nuestra reacción. Hay un poema, "Villaguay", que recuerdo que nos leyó. A él le gustaba mucho Villaguay. Porque en Villaguay está mucho más presente el monte que en Gualeguay. Gualeguay es ya la llanura, y ni siquiera hay colinas que empiecen...

El leía muchísimo, permanentemente. Se gastaba el dinero que no tenía en libros que pedía de Europa, como por ejemplo, la revista “Commune", que recibía de París, también "Lettres Françaises" y "Les Nouvelles Littéraires". Y, desde luego, leía a Aragón, Breton, y toda la vanguardia surrealista que en esa época adhería a la revolución. Así que solía leernos en francés y nos traducía. Otros poetas que leía, recuerdo, eran Hilarie Voronca, que era un rumano y a Boris Pasternak, el poeta. De la literatura argentina no escuché que le entusiasmara algún autor en especial. Aunque pudiera tener alguna simpatía, no le entusiasmaban. Tal vez Raúl González Tuñón, por quien tenía un gran cariño, y a la vez Raúl adoraba a Juan, pero su afinidad poética no era ésa. Tal vez con el santafesino José 
Pedroni, tal vez había una similitud con él. Pero que lo entusiasmaran como los surrealistas franceses, no conozco. Con respecto a la poesía entrerriana de Panizza o Saraví, aunque no adhiriera, era muy benévolo, no los denostaba abiertamente, aunque tenía una ironía tremenda... no era que les perdonara la vida, sino que realmente no le interesaban. Más bien le ocasionaban una sonrisa, ni siquiera reía, más bien sonreía.

A veces yo lo acompañaba a "La Carmencita", que era un campo de Beracochea, un pariente de él. Tenía un casco, bien puesto, quedaba a unos diez kilómetros de Gualeguay. Entonces, por invitación de él, íbamos al medio del campo, y nos quedábamos sentados ahí, sin hablar. Él decía: "no hay que hacer ningún ruido" y entonces escuchábamos el silencio poblado del campo. Y eso era un deleite, era algo maravilloso, y era un ejercicio que hacíamos casi cotidianamente, es uno de los recuerdos más gratos que tengo.

Con respecto a El agua y la noche, es cierto que fue Mastronardi quien le pidió los poemas y se los llevó, sino, no sé qué hubiera pasado... a veces suceden estos pequeños milagros, ¿̇no? La amistad con Mastronardi... claro, pero encontrar la afinidad poética de Juan con alguien era muy difícil, aún en la Argentina. De modo que Juan era un solitario, un poeta único y pese a que indudablemente Mastronardi es un gran poeta, me parece, no es de su calibre, es otra cosa. Él, Juan, podía ser amigo de todos los poetas, pero afinidad poética era muy difícil que encontrara. Tal vez por eso se refugiaba en los de Europa, pues no encontraba hermanos de sangre poética. Rafael Alberti también pasó por Gualeguay, creo que por Juan. 
Por Juan, Gualeguay recibió visitas insospechadas: Borges -aunque más por Mastronardi- Castagnino, Berni tal vez... Alberti consideraba que la poesía de Juan era un caso muy especial. En una conferencia que dio en La Plata mientras yo era estudiante al único que citó fue a Juan, y yo, que estaba presente, le pregunté por qué y él me dijo: “yo no vine aquí a citar a nadie, sólo que me parece verdaderamente un caso especial", y luego tuve que explicarle a mis propios compañeros quién era Ortiz, porque en La Plata, en Buenos Aires, no existían ediciones de Juan en esa época, nadie lo había leído ni lo conocía.

Una vez fui a parar al Departamento de Policía, en Paraná (fue un 9 de julio, o algo así, a mí siempre me ponían preso en alguna fecha patria...) la única visita que recibí fue la de un amigo, Pedrazzoli, que también era amigo de Juan. Porque nadie se animaba a venir, la gente tenía mucho miedo, habían logrado infundir el pánico diciendo que habría fusilamientos y esas cosas. Entonces, Julio Pedrazzoli me dice: “Mirá, estuve con Juan (había un policía parado en la misma habitación) y te manda esto", y me da un cigarrillo armado, no una caja, iuno solo! Yo me di cuenta que era un armado de los que fumaba Juan y lo guardé inmediatamente en el bolsillo, antes de que el guardia se diera cuenta. Después lo desenvuelvo, y en el papel había una carta que me había mandado, en el mismo papel que usaba para escribir sus poemas... era su letra, minúscula, esa letra casi ininteligible, en esa tira de papel.

Cuando Juan venía a Buenos Aires, solía parar en la casa de Córdova Iturburu, y ahí yo lo veía siempre. Venía con muy poco dinero, lo necesario 
para el viaje y para trasladarse para ver a los amigos. Entonces se reunía con González Tuñón, con Portogalo, con Petit de Murat, con Luis Emilio Soto... Cada vez que yo me sumaba, aparecía alguien... a Vicente Barbieri fuimos a visitarlo con Juan y con Petit de Mural al hospital Rawson, tenía tuberculosis, estaba terminal y se alegró mucho, pues nadie se animaba a ir por temor del contagio... Desde luego, también veía a Mastronardi (era por 1944, que fue un año muy duro, de mucha represión política y después en el ' 45 hubo más apertura, a fines del '45 hubo otra razzia, y en el '46 fueron las elecciones, que ganó el peronismo). Juan era amigo de todo el mundo y le tenían una estima increíble... porque, uno advertía que se lo conocía más en Buenos Aires que en Entre Ríos. En Gualeguay nadie sabía nada de él, no se lo apreciaba intelectualmente ni como poeta. También se reunía con Nalé Roxlo, que era un tipo de reírse, porque contaba un chiste tras otro, sin parar.

Yo me recibí de maestro, entonces decidí ir a Buenos Aires a estudiar literatura; mi familia se oponía, no sé sí Juan tuvo algún tipo de intervención con mi viejo, el hecho es que aceptaron. Y entonces entré en la facultad de Humanidades en La Plata. Yo le mostré a Juan los programas, la lista de profesores: Amado Alonso, Henríquez Ureña, Arturo Marasso, Arturo Capdevila, Abraham Rozenvasser, que iba a excavar a Egipto y era un historiador de primera línea... Juan me dijo, me acuerdo: "vas a la mejor facultad del mundo, esto es bárbaro", estaba enloquecido con lo que yo estaba viviendo. Bueno, él conocía a toda esa gente. 
Yo lo visitaba durante mis vacaciones en Gualeguay, era al primero que iba a ver; yo ya me habla afiliado a la Fede [Federación Juvenil Comunista], en La Plata. Él nunca había insistido ni había dicho nada para convencerme, para influir sobre mi decisión política y esas cosas, y entonces, fui y le conté que estaba en la Juventud. Él se emocionó, me hizo entrar a un cuarto y me dijo: "Mirá, te voy a mostrar una cosa". Tenía la colección completa de la revista Commune que dirigía Romain Rolland, abrió el ejemplar en la página central, estaba, a toda página, el carnet de afiliación al P.C. de Anatole France, nada menos; además de toda la pléyade de escritores, artistas, intelectuales, estaba Anatole France, y eso que era un insospechable... Entonces Juan me dijo: "Ahora, vos sos compañero de Anatole France". (Xul 44-45)

Emma Barrandueguy (1997):

Quiero agregar unas líneas sobre la "Agrupación Claridad" que fundáramos en Gualeguay con Juan y con Hartkopf para hacer efectiva en 1932 una tendencia que, por cierto, nos unía y respondía a los cánones de la época: la inclinación hacia una izquierda imprecisa pero que auguraba cambios importantes durante el siglo. Por supuesto que la Unión Soviética estaba en sus comienzos y soñábamos con un lugar sin fuerzas militares, sin matrimonio obligatorio para permanecer en el régimen legal y con adelantos educativos y una mejor distribución de la riqueza, cosas todas que no dejaron de ser sueños. 
Estar contra la guerra quizás fuera lo más lógico de todo, por eso "Claridad" organiza una exposición sobre las víctimas de la guerra del '14, que creó inquietud en el ámbito pueblerino donde comenzaron a atacarnos con encarnizamiento.

Organizo, por ese entonces, la publicación de mis primeras poesías que están totalmente dedicadas a "redimir al proletariado urbano y campesino".

Ortiz está presente en todo y, como era imposible reunirse en "Claridad" por mi condición de única mujer que no podía salir sola en horas nocturnas, las reuniones se hacían en casa, donde estudiábamos El Capital de Carlos Marx, editado por Maucci de Barcelona y que desde allí venía en fascículos. Quiero decir que, sin un guía empapado en el asunto, el tema de la plusvalía nos excedía, pero insistíamos en conocerlo para organizar nuestros intentos de penetrar en la literatura marxista. Sin descuidar la literatura misma, adherimos al grupo de Boedo que, por ese entonces editaba la revista Claridad, de tendencia socialista o izquierdista. Se hace notar, por los nombres de nuestra agrupación y de la revista, que nos inspirábamos en el grupo Clarté, dirigido en Francia por Henri Barbusse, militante del P.C. La actividad era intensa y los contactos semanales adonde nunca faltaba Juancito Ortiz con su bicicleta. Teníamos relación con la Capital gracias a un camarero del ferrocarril que nos visitaba periódicamente y traía material fresco y revolucionario. Asimismo nos vinculamos con Raúl González Tuñón, que fue mi maestro, y llegó a venir de visita traído por la GAC (Gualeguay Agrupación Cultural) que dirigía Roberto Beracocha, también 
miembro de nuestra "Claridad", y constante cultor de temas literarios de izquierda en esos momentos. Ortiz comenzaba así su militancia, que nunca desmintió a pesar de su espíritu delicado y exquisito, que es lo que actualmente destacan los comentaristas.

Fueron momentos de audacia y compañerismo que templaron mi espíritu permitiéndome decir, como Juan Ortiz, sus inolvidables palabras: “¿Cuándo, cuándo, el amor no tendrá frío?”. (Xul 42-43)

Carlos Serfaty (1937):

Cuando Juan Laurentino Ortiz nos entrega un libro suyo, $-\mathrm{y}$ ya lo habíamos observado cuándo El agua y la noche, aunque menos precisamente- nos quedamos pensando como él permanece, impasible e intacto, con su larga boquilla en los labios y el ademán inconfundible rasgando apenas el aire. Sin embargo, es así, Ortiz realiza el milagro de dársenos íntegramente y quedar, empero, intacto para las próximas entregas. El alba sube, es una superación de El agua y la noche, sin eclipsar, sin embargo, aquel bello resplandor. Acaso nos desconcierte un poco a los hombres de 1937 ese tono que hace diáfanas las palabras y nos envía el sonido de cada sílaba, milagrosamente atenuado. En época de tremendos problemas sociales nos sacude la serenidad de este hombre - que personalmente y zangoloteado por esos mismos problemas - se atreve a salvar, incólume, su verso. ¿Pero significa esto un aislamiento, una sordera voluntaria a los problemas de los hombres? 
Juan L. Ortiz es demasiado sincero, su verso demasiado desnudo para traicionar a su época y a su clase, y el estremecimiento de la angustia colectiva pasa por sus mejores poemas, noblemente, sin desfigurar el tono y sin falsos huracanes que transformen el clima. "Ráfaga del vacío" o "Estos hombres..." pueden ser nuestros. El final de "Estos hombres..." es de un lirismo humano, profundo y trágico. (Unidad 16)

Raúl Larra (1982):

Carlos Dujovne era un personaje singular. Más bien bajo de estatura, de ojos claros, que reboleaba hacia arriba, juntando de paso los índices cuando improvisaba audaces especulaciones teóricas, parecía un cura párroco antes que un bolchevique. Lo vi por primera vez en los comienzos de la AIAPE, en cuya fundación él interviniera con Aníbal Ponce, [Cayetano] Córdova Iturburu y otros intelectuales.

Dujovne hablaba parsimoniosamente, no alzaba la voz, no se enojaba, todo lo decía con tal acento de convicción que su interlocutor se prestaba a dejarse convencer. Había estado en la Unión Soviética en los años del hambre, enviado por una Comisión Argentina Pro-Ayuda. Allí se puso a estudiar diplomacia con Potemkin, luego vicecomisario de Relaciones Exteriores. De regreso a su país recaló en el Perú al filo de la muerte de José Carlos Mariátegui y cooperó en reorganizar el Partido Comunista Peruano. Más tarde pasó a Chile y se entreveró con la efímera revolución socialista de Marmaduque Grove. Hizo algunos contactos en la marina de guerra chilena hasta la caída de Grove. Según mentas Dujovne proyectó sin éxito que la flota 
trasandina enfilase rumbo a Vladivostok. Esto es muy posible sea inventado, pero conociendo al personaje puede admitirse un margen de credibilidad. De pronto Carlos Dujovne - Carlitos para sus amigos - instala en un rincón frontero de la Plaza Lorea, en la vecindad del Parque Goal la librería-editorial Problemas, difundiendo textos marxistas y de izquierda. Procura al mismo tiempo inducir a los escritores argentinos a abordar los temas sociales del entorno. Obsedido por el asunto de los frigoríficos a cuanto literato se le pone a tiro le sugiere lo encare en una novela que, desde luego, él se compromete a publicar.

Una vez apareció el poeta entrerriano Juan L. Ortiz y sin más le hizo la proposición. El autor de La rama hacia el este debía comentarme azorado: “Pedirme a mí una novela de los frigoríficos. A quien se le ocurre. ¿Te das cuenta?".

Juan L., todo entelequia, una boquilla enorme prolongando sus manos afinadas, escribía sus poemas de la naturaleza - El álamo y el viento, El agua y la noche, El alba sube, El ángel inclinado- en papelitos de seda con tinta evanescente que luego pasaba en limpio con una máquina de tipos diminutos, cercanos al cuerpo seis, era en verdad el menos indicado para empresa semejante.

Al fin Dujovne se salió con la suya. Por allí merodeaba Bernardo Kordon, flamante autor de La vuelta de Rocha, que se avino al encargo. Fruto del connubio fue La isla, que si no alcanzó contextura de novela le sirvió a Kordon para pintar los docks que supo explorar con ojos curiosos. 
Acaeció el movimiento militar del 4 de junio de 1943 y a la editorial Problemas le secuestraron libros y le echaron candado. Dujovne no se amilanó. Se presentaba todos los días en la Sección Especial contra el Comunismo a gestionar su reapertura. Mientras en los cines un noticioso difundía la quemazón de esos libros, Dujovne, impertérrito, iba todas las mañanas a la tenebrosa oficina de la calle Urquiza. Muy ocupados en detener militantes y en efectuar allanamientos, los policías le decían "venga mañana". Y al día siguiente allí de nuevo, haciendo amansadora en un banco mientras compañeros suyos ingresaban encadenados y se asombraban al verlo sentado, inmóvil como un Buda. (Etcetera 29-30)

Héctor P. Agosti (1945):

En la soledad de Gualeguay, aislado de los elogios fáciles y de los espejismos de las tertulias literarias, Juan L. Ortiz construye silenciosamente sus poemas[...] En el retiro de Gualeguay, Ortiz trabaja despaciosamente, brindando una admirable lección de humildad. Lejos de la gran ciudad multitudinaria absorbe el paisaje con tremenda y radiante exultación. La esencia de su poesía está en ese paisaje. Pero su trayectoria fundamental queda determinada por la conciencia del servicio social de la poesía. (Defensa del realismo 109-112)

La heterogeneidad de voces, perspectivas y soportes, que van desde la descripción pormenorizada en un ensayo a la alusión al pasar en un libro de memorias, funcionan en un 
doble sentido: iluminan a Ortiz, pero también a esa red de escritores e intelectuales donde la imagen del poeta circula y se construye.

Cabe consignar, por último, una notable diferencia de perspectiva entre los diferentes «testigos» del apartado anterior. Principalmente entre locales Mastronardi, Manauta, Barrandeguy y los porteños Serfaty y Agosti. Mientras que los primeros se detienen a detallar las actividades que Ortiz llevó adelante en el pueblo y destacan sus múltiples vínculos con los escritores nacionales y extranjeros a través de la amistad o de la lectura, los porteños insisten sobre el signo del aislamiento, la marginalidad y la curiosidad que supone consumar una obra de enorme calidad alejado de la gran urbe. Ambas perspectivas conforman, combinadas, la fluctuante imagen del poeta. 


\section{El poeta en la comarca}

Uno de los objetivos iniciales de esta investigación era dar cuenta, en la medida de lo posible, de las acciones de Ortiz en su pueblo. Buscar indicios de una posible biografía de ese hombre sin biografía.

¿Qué hacía el poeta? ¿Qué lo llevó a Buenos Aires? ¿Qué lo trajo de vuelta a Gualeguay? Bajo esa aparente inmovilidad, la biografía de Ortiz revela una abundante actividad cultural, y un recorrido no menos llamativo de su pensamiento y militancia política. Ortiz actuó en las filas del radicalismo en 1912, luego en el anarquismo alrededor de 1914, y más adelante en el comunismo. Darle entidad al poeta en la comarca, amplificar los signos en apariencia menores de las disputas pueblerinas, tiene el doble objetivo de dar a conocer referencias perdidas y permitir comprobar su posición política, y la manera en que esa perspectiva dialoga con sus decisiones estéticas.

\section{Ortiz y el paisaje de la infancia}

Ortiz nació en 1897 y pasó algunos años de su infancia campesina en Mojones Norte, al norte Villaguay. En el entorno de la llamada Selva de Montiel que paulatinamente se perdía para dar lugar a las chacras. Sobre aquellos años hay un testimonio de Evar Ortiz (1997), el único hijo del poeta: «Cuando mis abuelos se radicaron en Villaguay, por razones de trabajo de mi abuelo, mi padre vivió un tiempo en el campo y debió ir a la escuela a caballo. Y para ayudar en las tareas salía al monte, tomando contacto directo con esa naturaleza que lo impresionó vivamente. Y conoció profundamente aquella "selva" de Montiel, que tantamente lo marcó» (Xul 41) 
Ortiz cursó hasta sexto grado en el colegio de Villaguay y luego se mudó a Gualeguay: «Allí en Gualeguay estudié en la Escuela Normal, soy medio maestro y comencé mis escapadas a Buenos Aires donde cursé estudios libres en Filosofía y Letras» (Veiravé 29).

\section{El viaje iniciático}

Ese viaje a Buenos Aires, esa «escapada», ocurrió cuando Ortiz tenía solo 17 años, en 1914. Hay un testimonio sorprendente de la llegada de Ortiz a Buenos Aires escrito por Salvadora Medina Onrubia. La actriz y poeta nacida en Buenos Aires había pasado su infancia y adolescencia en Gualeguay, de allí el contacto entre Ortiz y esta mujer que se convertiría, con el tiempo, en una de las más destacadas figuras femeninas del anarquismo argentino. Medina Onrubia plasmó la bienvenida de su amigo en las páginas de Fray Mocho el 6 de marzo de 1914, con un artículo titulado: «A caballo, a pie, a nado, en bote. Un pintor y poeta entrerriano que quiere hacerse célebre». Por el valor sensible, documental, y sobre todo por la inédita imagen que brinda de un jovencísimo Ortiz, se reproduce íntegro en el Apéndice.

Ese mismo mes de marzo de 1914, Medina Onrubia se había hecho cargo de la sección literaria del periódico anarquista La protesta. Según Pablo Ansolabehere (2011), quien estudió en profundidad el vínculo entre anarquismo y literatura en Argentina, «sin dudas la publicación más importante del anarquismo argentino» (24). Al parecer, varios poemas militantes de corte anarquista de Ortiz, «con ideas hermosas que llegan a los nervios» y «versos llenos de rugidos», tal como los describió Medina Onrubia, fueron publicados en esa sección que salía los domingos y guardaba una periodicidad semanal. Hay ejemplares de $L a$ protesta microfilmados en el CEDINCI, en Hemeroteca de la Biblioteca Nacional y también 
en la hemeroteca del Congreso de la Nación. En ninguno de esos repositorios se encuentran los poemas de Ortiz. Hecho que puede adjudicarse, casi toda certeza, al deterioro y la importante cantidad de material faltante.

\section{Anarquismo, los hechos}

De todas maneras, existen otros registros para acercarse a esa época de Ortiz. Dentro de su propia obra, en el poema autobiográfico «Gualeguay», publicado en 1954, pero leído por el poeta en los festejos del 170 aniversario de fundación del pueblo en 1953. Allí, Ortiz menciona distintos personajes de la «bohemia porteña», para culminar con Salvadora: «—a Salvadora, "hermana mayor", de fuego santo, la veía allá por los mítines y los teatros...» (En el aura del sauce 57). El verso entrega una valoración y también una escena. Una valoración sobre la figura de Salvadora Onrubia, sobre el vínculo que los unía: la hermandad. Y una escena, propia de aquella bohemia anarquista argentina de principios de s. XX, de la de la que el poeta es partícipe directo: los mítines y el teatro.

En la antología que Juana Bignozzi realizó en 1969 de la poesía de Ortiz para Carlos Pérez Editor, titulada Juanele. Poemas, aparece, después de los poemas (esos a los que Ortiz llamó «poemacidios») y de una recopilación de ensayos del propio autor, una sección llamada «Testimonio». La base es un reportaje que le realizó Bignozzi a Ortiz. El modo en que están moduladas las declaraciones y el propio relato en la escritura genera ciertos inconvenientes para tomarlo como fuente: el discurso de Ortiz, que aparece puesto entre comillas, guía o se enmarca en un discurso narrativo de Bignozzi que recurre, por su parte, a datos extremadamente específicos atribuibles únicamente a la fuente, es decir, al propio Ortiz. Pero que sin embargo, al aparecer en tercera persona y sin comillas, estrictamente no 
deben usarse como declaraciones. Como sea, incluso en su equívoca presentación, ese «Testimonio» ofrece detalles interesantes sobre estos primeros años del poeta. Está dividido por entradas. A la primera de ellas, titulada, «Bohemia y anarquismo», pertenece este fragmento:

Cuando viene a Buenos Aires, a los 17 años buscando “...lo que se llama un poco de contacto, deseando o anhelando vida literaria, a la vez me disgustó" ya habían quedado atrás el Puerto Ruiz natal, el monte, las reuniones de la tarde con los amigos de su padre [...]Aquí [en Buenos Aires] fueron las largas caminatas desde el conventillo de Villa Crespo, o desde Sarandí, donde vivía con la tía, hasta las bibliotecas, las reuniones con los escritores anarquistas como Ghiraldo, González Pacheco, la tertulia de Ugarte en su casa de la calle Rincón a la que a pesar del recibimiento, fue una sola vez porque “...tuve la impresión de que había gente muy inteligente, muy brillante, muy ingeniosa, pero que leía poco...", las clases en la facultad y en el Colegio Internacional de Olivos, si, “...fueron tres años muy vividos, una bohemia hambreada, caminada..." y la vuelta, porque estaba cansado, sentía deseos de ver el pago. ..Cuando vuelve "al pago" ya se estructura el esquema de su vida, la actividad política, “...fuimos de los primeros anarquistas que adherimos a la Revolución Rusa. Muy jóvenes habíamos formado el grupo de `Amigos de la Revolución Soviética'..." (117-118)

En la página siguiente, dentro del apartado «Lecturas e influencias», una anécdota termina dando pie a una a revelación central por parte de Ortiz: 
Antes de eso habían sido los enamoramientos sin consecuencias... de esa época me acuerdo de este poema: “...ha amanecido el gris la pobre almita frágil en los sueños desde la brusca claridad huía a su sombra más honda, se asoma ahora a su balcón y en la baja luz de ceniza prosigue su sutil labor...", no sé por qué me acuerdo. Se parecía a Rilke y eso que yo era anarquista y difundía La protesta y conocía las embestidas de la policía. (119)

Un ejercicio de constatación de fechas, tópicos y vínculos, termina arrojando un resultado que, siguiendo esta confesión, coloca la experiencia de Ortiz en una suerte de punto neurálgico del desarrollo histórico del anarquismo en Argentina. Salvadora Medina Onrubia fue, como se ha dicho, un nombre de peso en la historia del anarquismo argentino. De ella puede decirse que colma y rebalsa la figura de «compañera de la bohemia» que traza David Viñas (2005) en Literatura argentina y Política: un rol de mujer inédito hasta entonces, introducido precisamente por la sociabilidad anarquista a principios de siglo XX. «Las compañeras de la bohemia: esas inquietantes mezclas de secretaria, "de amante y madre", sostenedoras de las huelgas de los conventillos...» (260). Para el Ortiz anarquista, Salvadora es su «hermana mayor». En el mismo «Tetimonio» de Bignozzi se relata que ella, frente a la necesidad del poeta de volver a sus pagos, le ofreció trabajo en una de las estancias de la familia de Natalio Botana, con quien se encontraba en pareja desde 1915. Ortiz declinó, se decidió por el que sería su trabajo de por vida como 2do jefe del Registro Civil de Gualeguay. Este puesto, que le fue ofrecido por los radicales - con quienes había compartido su militancia inicial como orador de las puebladas de 1912- le permitía mayor tiempo para sus lecturas y le dejaba libre los fines de semana. Interesa resaltar que Medina Onrubia no sólo fue su puente con el universo anarquista porteño, no solo difundió su obra, sino también se 
preocupó por el sustento del poeta. Madre soltera a los 16 años de edad, oradora en los mítines callejeros (como el que se convocó para pedir la libertad de Simón Radowitzky — anarquista ucraniano-argentino, autor del atentado que terminó con la vida de Ramón Falcón- el $1^{\circ}$ de mayo de 1914), la figura de Medina Onrubia rebalsa, como se indicó, el rol de «compañera de bohemia». Su producción poética, su producción teatral, los avatares personales y de la propia política la irían convirtiendo, con los años, en un verdadero caso. Aunque podría argumentarse que toda biografía de un anarquista que se precie es necesariamente un caso, en el sentido de que se presenta como un itinerario excepcional, la de Medina Onrubia, sobre todo a partir de la década de 1940, a medida que avanzan los elementos místicos, las depresiones y una ambigua relación con el poder político y mediático, parece deslizarse por zonas difícilmente vinculables al imaginario libertario. Pero durante aquellos años previos en que compartió la experiencia con Ortiz fue, sin duda, una de las principales militantes anarquistas de la argentina.

\section{Ortiz en Gualeguay}

Ortiz regresó a Gualeguay y comenzó a trabajar en el Registro Civil. No perdería, en lo sucesivo, el contacto con Buenos Aires. Claudia Rosa analiza de manera certera, en su estudio «Entre Gualeguay y Paraná» -incluido en la Obras Completas de Amaro Villanueva, editadas en 2010 por UNER - la escena cultural gualeya en su conjunto y en su relación con Buenos Aires:

Las ciudades de provincias en 1920 parecen desplegarse como en una doble temporalidad, en donde los discursos culturales de la época se articulan sobre lo que aparecía como rasgo diferencial de los debates comarcanos. Las 
corrientes estéticas comienzan a ser percibidas, en el interior, como en la órbita de la centralidad porteña, experiencia nueva si se piensa que hasta el 900 no existía todavía el convencimiento, dominante a lo largo del siglo, de que el interior del país no podía tener su propio centro. La tradición intelectual entrerriana hasta esos días no sentía que tenía que pasar por Buenos Aires para aggiornarse y, muy por el contrario, mantenía las posibilidades, por ejemplo, de un puente Gualeguay-París. (54)

El caso de Gualeguay, con su particular escena de la que participan varios nombres relevantes de la literatura y el arte, debe en parte su origen a una experiencia filantrópica que Rosa rescata del olvido:

La presencia de Juan L. Ortiz era tan resonante como la del doctor Epele. Habiendo cursado algunas materias en la facultad de medicina, este filántropo creó un hogar de niños pobres y huérfanos para darles una educación abierta, artística e innovadora. Su tarea alcanzó la fama y convocó a muchas familias pudientes a sustentar el proyecto. Del hogar salieron grandes artistas plásticos como Cachete González y Antonio Castro. Ortiz, Villanueva, Mastronardi, Barrandeguy, Antonio Gamboa Igarzabal, Juan José Manauta, Aníbal Romeo Cúneo, Roberto Beracochea, Salvadora Onrubia de Botana -quien se va a Buenos Aires en 1914 y regresa a veces por largas temporadas-, los Gianello, configurarían una comunidad de artistas, escritores e intelectuales. Impulsaban a su manera la vida cultural, en medio de una burguesía que incluía algún que otro marchant (las pinacotecas privadas de Gualeguay tenían pretensiones de relevancia). (54) 
Una simple hojeada de las publicaciones de la época conservadas en la hemeroteca de la Biblioteca Popular «Carlos Mastronardi» de esta ciudad, basta para comprender el grado de dinamismo que alcanzaron allí actividades culturales durante las décadas de 1920 y 1930. Estaban dadas las condiciones, que Ortiz y otros escritores hicieron realidad, de desplegar, en aquel ámbito pueblerino, una vida vinculada a la creación y la bohemia. Claudia Rosa tienta, en el pasaje que se viene citando, una serie de hipótesis respecto de la articulación que se da entre los artistas y los otros sectores del pueblo:

[La] oligarquía ganadera, que en los años treinta comenzaba a sentirse menoscabada por la poderosa oligarquía porteña, apuesta decididamente a crear un valor agregado al hecho de vivir en provincias, asimilando entre otras cosas la bohemia como un arte de vivir, el dandismo, y cierta laxitud en la aceptación de las sexualidades diferentes. Los creadores en comarca deben vérselas siempre con otras formas espurias de legitimación, de construcción de falsos mitos o de "figurones", como decía Juan L. Ortiz. Estos figurones eran inventados o por los "amigos de los caudillos políticos de turno" o por "los profesores académicos". Todo un sistema de relaciones familiares, sociales, que asfixia los modos de reconocimiento. (54)

Otras eran las redes de sociabilidad y legitimación que construían los grupos de poetas y artistas vinculados a Ortiz. Sus acciones culturales se conciben bajo otros modelos y con una decidida intención militante que no escapa a Rosa, quien se centra en dos experiencias en las que participó el poeta. La primera de ellas, la agrupación Claridad: 
En 1932 se forma el grupo denominado Claridad que, como su nombre lo indica, adscribía a una ideología de izquierda. Estaba encabezado por Juan L. Ortiz y Emma Barrandeguy, junto con Hartkopf el librero. Y, mientras se estudiaba El Capital de Carlos Marx, se militaba en el Mercado Borré con los obreros, en donde llegaron a tener escudo en la puerta, una biblioteca y una imprenta. Es este grupo quien comienza a establecer relaciones con la Sociedad de Fomento Educacional, que estaba a cargo de la Biblioteca Pública -hoy denominada "Carlos Mastronardi"-, a raíz de la activa participación de pintores y músicos. La ideología marxista se articulaba con mayor naturalidad con los republicanos españoles y con algunos radicales yrigoyenistas, enfrentados con los alvearistas, a cargo del gobierno de la provincia de Entre Ríos, ya que no habían sido destituidos por el golpe de Estado de Uriburu. El debate del grupo Claridad va a ser fundamental luego en las trayectorias escritúrales de sus miembros. Buscaron la construcción de un soporte teórico y estético que habilitara el concepto de comarca, la reivindicación de lo lugareño y del federalismo -en un momento de predominio de un marxismo con fuertes tendencias internacionalistas e industrialistas-; esto obligó a sus miembros a una lectura atenta de la obra de Marx. (55)

La segunda experiencia se da en paralelo a la existencia del grupo Claridad, aunque su desenlace, que alcanza ribetes novelescos al desatarse una persecución anticomunista, tendrá su epicentro unos años más tarde, entre 1935 y 1937. Es un episodio cultural de 
innegable trascendencia para la historia de Gualeguay y del Litoral, y uno de los grandes hitos de la biografía intelectual de Ortiz. Continúa Rosa:

Un grupo de escritores decide tomar la Biblioteca Popular, para lo cual Mastronardi, Ortiz y Beracochea comienzan a militar a partir de 1932. Ese año se presentan a las elecciones pero pierden y recién en diciembre de 1934 logran ganar la presidencia de la Comisión Directiva, que por dos años estará a cargo de la Biblioteca y será el centro de actividades de Gualeguay. Es en este período que promueven las visitas de Samuel Eichelbaum, Cesar Tiempo, Atahualpa Yupanqui, Ulises Petit de Murat, Raúl González Tuñón, Pablo Rojas Paz, y en el que, sobre todo, comienzan a establecerse fuertes lazos con grupos de Paraná, en los cual ya trabajaba activamente Villanueva. La Comisión pierde la dirección de la Biblioteca en mano de los grupos conservadores, y la disputa es tan violenta que puede seguírsela día a día en los diarios de la época. Por otro lado, en febrero de 1937 se realiza en Entre Ríos la mayor purga contra los docentes y estudiantes judíos del país. El diario conservador los acusa de haber usurpado los títulos. Este medio denuncia además la existencia de comunismo en Entre Ríos, publicando los nombres de todos los integrantes del PC en la provincia, e informa que han sido retiradas las publicaciones comunistas de la biblioteca. (55)

Es interesante colocar este último pasaje de la cita al trabajo de Claudia Rosa en el contexto amplio de las luchas del comunismo y el rol de los escritores e intelectuales. Puntualmente, dos hechos centrales inquietaban el universo de los comunistas hacia 1937: el avance imparable del nazismo en Alemania, con sus ramificaciones y contagios, y las vicisitudes de 
la Guerra Civil Española. Esta última, sobre todo, se volvió una bandera, la madre de las batallas contra el fascismo.

En este sentido, el derrotero de Raúl González Tuñón, sobre el que se volverá en el segundo capítulo de esta tesis, con sus idas y vueltas al viejo continente, es emblemático. Sin ser oportunista, Tuñón estuvo en el lugar correcto en el momento indicado. En París, para el Congreso de Escritores de 1934. Allí tomó contacto con la intelectualidad de izquierda francesa, que había organizado el CVIA (Comité de Vigilance des Intellectuels Antifascistes). En España, en dos ocasiones, la última, en 1937, para el Congreso de Escritores para la Defensa de la Cultura.

Tuñón, Paz, Pablo Neruda, Cesar Vallejo, el cubano Nicolás Guillen, Vicente Huidobro, son algunos de los escritores sudamericanos que estuvieron presentes en España para dar su apoyo a la causa republicana. Este movimiento tenía una correspondencia estratégica a nivel del Partido Comunista con los Frentes Populares. Con la experiencia española como epicentro, comenzaron a florecer, a escala global, alianzas tácticas del PC con sectores hasta entonces considerados como enemigos, muchos de ellos liberales y burgueses, con el objetivo de formar frentes que impidan el avance del fascismo.

Argentina no fue la excepción. El Comité de Vigilance des Intellectuels Antifascistes de París sirvió de modelo a Aníbal Ponce, intelectual de izquierda pero no orgánico del Partido, para crear la AIAPE (Asociación de Intelectuales, Artistas, Periodistas y Escritores en contra de fascismo) en 1935, en Buenos Aires. Esa asociación haría uso de las redes de sociabilidad del Partido Comunista Argentino, contribuyendo al intercambio intelectual, la formación y la difusión del antifascismo a lo largo y a lo ancho del país. Al año de funcionar, la AIAPE tenía más de 2000 socios y filiales en Rosario, Tandil, Paraná, Gualeguay, Corrientes, Tucumán. La clave lógica para comprender la articulación, es la siguiente: la AIAPE no era directamente el 
Partido Comunista Argentino, pero el Partido vehiculizaba a través de ésta su estrategia de Frentes Populares en el terreno de la cultura. Sus principales intelectuales dirigían las publicaciones, como el caso de Héctor P. Agosti y Rodolfo Puiggrós. En Unidad primero, y luego en Nueva Gaceta, se difundía la obra gráfica de socios-camaradas como Antonio Berni, Lino Enea Spilimbergo o Leónidas Gambartes; investigaciones periodísticas de Roberto Arlt; poemas de Juan L. Ortiz, Vallejo, Neruda y, por supuesto, de Raúl González Tuñón.

En este tránsito, en esa lucha global particularizada se desenvuelve el asunto de la Comisión Directiva de la Biblioteca Fomento de la que habla Claudia Rosa. Las conexiones son múltiples y están poco estudiadas. Es en ese contexto que debe entenderse la denuncia masiva acerca del comunismo en Entre Ríos (donde se lo menciona directamente a Ortiz) que realiza José María Rosa, el padre del historiador revisionista, y leader del laboralsocialismo, desde el periódico La voz de Entre Ríos, el sábado 27 de febrero de 1937:

El gobierno de E. Ríos engaña al país diciendo que hay libertad de trabajo y no existen agrupaciones extremistas. Clara y terminante refutación del Dr. José M. Rosa. Entre Ríos presionada por los Soviet Rusos. Antecedentes. El diario "La Nación" publicó informaciones de sus corresponsales en Entre Ríos sobre los movimientos obreros, lo que fue refutado por el ministro de gobierno, Sr. Mundani; en vista de esto, el Dr. José María Rosa, que ha realizado viajes por Entre Ríos, escribió a “La Nación” dando la razón al corresponsal y exponiendo algunas de las tantas enormidades que conocía sobre la situación de los trabajadores y el extremismo. A esto contestó el gobierno de Entre Ríos en una publicación oficial, negando que hubiera 
conflictos entre los trabajadores y de que existieran agrupaciones extremistas.

En vista de esto, el Dr. Rosa resolvió una seria investigación, cuyo resultado es el que sigue, lamentándose que el tiempo que disponía no ha permitido dar mayores detalles. (J. M. Rosa)

La nota es demasiado amplia para transcribirla entera, pero los párrafos iniciales permiten percibir el tenor de la misma:

Basta recorrer la provincia para darse cuenta que la realidad es bien distinta de la que pintan y que negando los hechos para seguir en actitud pasiva y tolerante, lo que se consigue es fomentar las peligrosas actividades que desenvuelven los agentes de la Internacional Comunista.

. . La campaña disolvente despertando odios, y creando un ambiente contrario al orden y a la paz social, como las actividades subrepticias encaminadas a minar la disciplina de los cuerpos del Ejército destacados en Entre Ríos, se realiza en toda la provincia bajo las directivas de agentes designados por la Kominstern de Moscú ayudados por gran parte de la población judía que constituyen la mayoría de las agrupaciones comunistas y afines. También fuertes núcleos de radicales oficialistas fomentan las actividades comunistas. .. (J. M. Rosa)

Pero cabe indicar, a modo ilustrativo, que José María Rosa se ocupa de denunciar, en una página y media de gran formato, con nombre, apellidos e instituciones concretas, la presencia «soviética» en Paraná, Villa Crespo, Seguí, Viale, Bovril, Villa Federal, Concepción 
del Uruguay, Basavilbaso, Concordia, San Salvador, General Campos, Villa Clara, Colonia Caseros, Nogoyá, Villa Mantero, Diamante, y, claro está, en Gualeguay:

En Gualeguay las paredes están llenas de letreros comunistas; en las calles Ayacucho y Rosario de Tala, en los paredones del cementerio, en todas partes han colocado letreros del tenor siguiente: "Viva el Partido Comunista". "Para tu bien, votá al Partido Comunista". "Lucharemos por la libertad de R. Ghioldi y L. C. Prestes y demás presos del Partido Comunista". etc. El Centro Comunista no tiene local propio y sus dirigentes se reúnen en varias partes, principalmente en el local del Sindicato de Obreros Panaderos. Existe además el sindicato de Oficios Varios y el de Obreros Ferroviarios sito en la calle Salta y Cerrito, que en su origen eran defensores de sus intereses gremiales y hoy están contaminados por las ideas disolventes y la prédica comunista de Moscú.

En Gualeguay hay una filial de la AIAPE de la que son dirigentes el doctor Francisco M. Crespo, doctor Mauricio Resonsky, médico; José S. Miguez, senador radical; Juan Ortiz, $2^{\circ}$ jefe del Registro Civil; A. Yañez, maestro de escuela nocturna; doctor Roberto Beracochea, catedrático de la Escuela Normal, designado por indicación de los demócratas nacionales, y los señores, Carcaracha, Mastronardi, Chichizola, Emma Barrandeguy Delamare, el escribano Irigoyen, Días, Román y otros.

En el manifiesto dado con motivo de su fundación se lee el siguiente párrafo: “El criterio de clase impuesto en las Universidades, los procesos iniciados a escritores y artistas que honran al país, la persecución ejercitada contra 
numerosos centros de carácter cultural popular y la imposición del catecismo de obediencia en todos los órdenes de nuestra vida civil, reclama una acción conjunta y solidaria de aquellos que alientan algún fervor por las conquistas del liberalismo y por todos los ideales de redención humana".

La AIAPE de Gualeguay aparece como adherida a la existente en Capital Federal.

En concomitancia con la AIAPE está el Centro "Claridad" y la "Biblioteca Fomento Educacional", que celebra conferencias comunistas en su local, como la dada el 9 de diciembre último por Barboza Mello, autor del folleto titulado "Luis Carlos Prestes: El caballero de la esperanza y la revolución brasileña". Su esposa María Iris Ermelinda Bosio de Barboza Mello, “educadora" argentina está prontuariada en la Capital Federal bajo el número 6155 [corte en la hoja, ilegible] Sección Especial, y se la menciona como casada con el dirigente comunista brasileño José Barboza Mello, expulsado del Uruguay por sus actividades ideológicas: la esposa actúa en organizaciones femeninas colaterales del Partido Comunista.

En esa forma entiende la comisión de la Biblioteca cumplir sus tareas de "Fomento Educacional". Y esto sucede en una provincia gobernada por quien ha sido educador toda su vida". (J. M. Rosa)

En la denuncia de Rosa, el caso Gualeguay es uno de los más detallados pero no el más Ilamativo. Ese lugar lo ocupa, sin dudas, la localidad de San Salvador:

San Salvador es una localidad situada al norte del departamento de Colón, que reviste excepcional importancia para los comunistas por ser el punto 
donde se reúnen los dirigentes que vienen del Brasil, Uruguay y Paraguay, con los que van desde Buenos Aires a las diversas provincias argentinas, y por tener un gran arsenal para utilizar en las revoluciones que proyectan en el Uruguay, Brasil y Argentina. (J. M. Rosa)

Ortiz, Mastronardi, Barrandeguy y los distintos grupos e instituciones en las que se movieron (Claridad, AIAPE y Fomento), aparecen hilvanadas en el resumen de las actividades comunistas de Gualeguay que realiza José María Rosa. Aparecen ellos, pero otras cosas también. «Prestes», sin ir más lejos, dos veces mencionado. «Prestes» es el título de un poema de Juan L. Ortiz. Un conmovedor poema incluido en La brisa profunda, de 1954, que no habla del líder revolucionario brasilero sino de un perro que lleva, en homenaje, su nombre. De un galgo, su compañero de las tardes frente al río, de las noches de desvelo en la escritura.

Se ha dicho que la situación del comunismo criollo ha cambiado al mismo tiempo que la del comunismo internacional; también que la nueva estrategia de Frentes Populares, que vino en reemplazo de la de Lucha de Clases, desechaba los elementos de enfrentamiento franco con la burguesía y sus partidos, y tendía a las alianzas con los espacios políticos liberales y progresistas. Pero no se ha puesto, aún, nombre a ese nuevo aliado nacional de los comunistas criollos: el radicalismo. Desde el punto de vista comunista, la alianza era un paso hacia la formación estratégica de Frentes Populares para frenar el avance del fascismo. Desde el punto de vista de los radicales, mayor poder militante, territorial; pero sobre todas las cosas, estando proscripto el PCA, mayor caudal de votos en las elecciones provinciales. 
Una hipótesis posible es que José María Rosa buscó aprovecharse del fantasma del comunismo de la estrategia de Lucha de Clases, la etapa violenta, para intentar socavar esa alianza; quitar votos y brazos al radicalismo y dividir el Frente Popular. Lo suyo fue, en definitiva, una campaña de miedo.

En el tomo 2 del Proyecto de ley de Represión del Comunismo presentado por Matías Sánchez Sorondo en el Senado de la Nación en el año 1940, que corresponde a los antecedentes del proyecto de ley y contiene un rastrillaje de las revistas de izquierda de la década, fotos de las banderas comunistas, testimonios, reportajes con los principales dirigentes del PCA, se incluye un compendio de las leyes provinciales anticomunistas que fueron poblando el mapa argentino en la segunda parte de la década de 1930. El Proyecto de ley de Represión del Comunismo brinda, de esta manera, una estupenda radiografía del PCA y, sobre todo, de la forma en que era combatido.

Se cita un pasaje de los fundamentos del decreto $N^{\circ} 137$ de prohibición de propaganda comunista en la Provincia de Buenos Aires, del 20 de mayo de 1936:

El programa comunista ha tenido principio de ejecución práctica en países americanos, algunos limítrofes al nuestro, como consecuencia de la acción de agentes comunistas nacionales e internacionales, lo que ha dado motivo a perturbaciones políticas, sociales y hasta militares de distinta gravedad que ha determinado la adopción de medidas drásticas y excepcionales contra elementos disolventes[...]Al amparo del llamado "Frente Popular" o alianzas con otros partidos, el Partido Comunista se ha infiltrado en diversos organismos políticos y culturales aparentemente inofensivos. (Sanchez Sorondo 542) 
Sigue el inciso «b» del artículo 1 ro del decreto $N^{\circ} 2.495$ del gobierno de Salta, de octubre de 1936:

Prohibir en el territorio de la provincia de Salta la instalación y funcionamiento de todo centro, asociación o agrupación que revista carácter comunista y proceder a la inmediata clausura y disolución de los mismos, sometiendo a sus componentes a juzgamientos de los tribunales ordinarios para su castigo con las sanciones que establece el Código Penal. (Sanchez Sorondo 545)

Y continúan, en el mismo sentido, los decretos de las provincias de Mendoza, San Juan, Corrientes, San Luis, Tucumán y Catamarca. Atentos a estos decretos y leyes anticomunistas, puede advertirse que la postura de José María Rosa estaba lejos de ser original. Lo movía el espíritu de cuerpo. Rosa exagera porque tiene un buen motivo para hacerlo. Entre Ríos es un episodio más de la batalla que venían librando los conservadores nacionalistas, provincia por provincia, para conseguir leyes anticomunistas.

Interesa destacar el arco que traza esta denuncia. El pasaje que va de la disputa pueblerina por el comando de una Biblioteca a una arremetida en la prensa provincial y nacional, con la mira puesta en el endurecimiento de las leyes represivas contra el comunismo. Y, a su vez, consignar el peso que dicha persecución pudo haber tenido en el pedido de jubilación extraordinaria de Ortiz y su mudanza, junto a su mujer Gerarda, su hijo Evar y su perro Prestes, a Paraná, en 1942. 
Ortiz en Paraná: vida intelectual

Las referencias a la vida de Juan L. Ortiz en Paraná son mucho más frecuentes a partir de la década de 1950 y 1960, que en el breve período que va de 1942 a 1946. Sin embargo, a partir de la correspondencia y de las publicaciones, se puede afirmar que mantiene intactas sus conexiones con Buenos Aires, y se refuerzan sus relaciones con la vecina ciudad de Santa Fe. Claudia Rosa, en el ensayo ya mencionado, explicita la pertenencia de Ortiz al círculo intelectual que rodea, en Paraná, a Amaro Villanueva.

En un reportaje realizado por Alicia Dujovne Ortiz en La opinión cultural en 1978, reproducido en Capítulo 105, dice Ortiz sobre el tránsito entre Gualeguay y Paraná y la continuidad de la labor intelectual:

Y así viví, en Gualeguay, hasta que en el 42 me jubilé con jubilación extraordinaria y nos vinimos a Paraná... para estar más cerca del... movimiento.... de la gente... En Gualeguay hacía sociedad con muchachos amigos de la lectura, de la canoa, del paisaje... Hacia listas de libros para la Biblioteca, que se puso al día con todo el pensamiento del mundo. Córdova Iturburu vino a verla y se quedó sorprendido: "Pero ni en las bibliotecas de Buenos Aires tenemos esto" dijo. Yo "pescaba" y traía traducciones del ruso, del japonés, literatura africana, todo. Descubrí, por traducciones francesas, a Panait Istrati y a Pasternak antes de que en la misma Europa los apreciaran tanto... Y de Rabindranath Tagore, que tradujo al inglés y al francés, a los poetas hindúes, tomé cosas que traduje, algunas publicadas, otras, no. También Maiakovski. Muchas traducciones hice, muchas, de Aimé Césaire, de Snghor, antes de que los conocieran tanto... con un amigo de acá, Rubén Turi, 
traduje varios libritos de Louis Aragon. Y chinos, poetas chinos, porque me ayudaron unos muchachos de China que sabían castellano. (178-79)

Cabe consignar, como un adelanto del siguiente apartado del capítulo, que esta labor intelectual que llevó a cabo Ortiz en los primeros años de su estancia en Paraná, tuvo una importante circulación en el universo del comunismo criollo. Sin ir más lejos, la editorial Futuro, fundada y dirigida por el escritor y militante comunista Raúl Larra, publicó sus traducciones de Legión, de Jean Cassou (1944) y de Los hermosos barrios, de Louis Aragon (1945). 


\section{Un escritor comunista}

¿Cómo llega un escritor a convertirse en un escritor comunista? ¿Qué es, en todo caso, lo que lo define? ¿Su militancia? ¿Su obra? Estas preguntas, que están en la base de los estudios de Álvaro Yunque sobre la poesía comunista en Argentina que se analizan en el capítulo siguiente de esta tesis, son totalmente pertinentes, a su vez, para este apartado. Fuera del contexto de esta investigación, añadirle a un poeta como Ortiz la categoría de «comunista» puede resultar insólito y desconcertante. No así, por ejemplo, en el caso de Raúl González Tuñón. ¿Cuál es la diferencia entre ellos, entonces? Cada interrogante abre un campo diferente de posibles respuestas.

Probada la militancia personal de Ortiz, resta recorrer el proceso que lo llevó a convertirse, entre 1936 y 1946, en un poeta publicado y reconocido por sus camaradas comunistas a nivel regional y nacional; y en un escritor que, en ocasiones puntuales, puso su obra al servicio de la causa del PCA. La imagen de Ortiz como un escritor comunista se forja en el itinerario que siguen su figura y sus poemas desde su aparición lateral en la revista Claridad en 1930, hasta su lugar central en Poetas sociales de la Argentina de Yunque en 1943. Un escritor comunista cuya obra y figura, no está demás aclararlo otra vez, no comparte casi ninguno de los rasgos prototípicos del escritor militante de izquierda, es decir, el estar presente en el frente de combate, la estética virulenta, la palabra punzante, la incitación flagrante a la revolución. De allí la importancia de mantener el interrogante sobre qué se entiende por escritor comunista. Mantener esa tensión entre lo que se supone que debe ser y la comprobación de lo que efectivamente ocurrió. 


\section{Ortiz en la revista Claridad}

Políticamente hablando, el camino que sigue Ortiz no resulta tan singular: del radicalismo combativo de los caudillos entrerrianos hacia la izquierda más o menos radicalizada, como tantos otros comunistas y socialistas. Pero a nivel de estrategia literaria, es decir, de cómo logró visibilidad sin estar en el centro, como trascendió las barreras del pueblo para vincularse con referentes nacionales, eso sí resulta verdaderamente original. Y fruto, claro está, de un trabajo en conjunto donde mucho tuvo que ver, inicialmente, su amigo Carlos Mastronardi. Sin ir más lejos, es él quien lo pone en contacto con Cesar Tiempo, uno de los poetas, escritores y editores más importantes del grupo de Boedo.

El 14 de abril de 1930, Ortiz le escribió a César Tiempo desde Gualeguay:

\section{Amigo Tiempo:}

En mi poder sus atentas y bondadosas líneas que no había contestado antes porque tenía el firme propósito de mandarle algo mío y adolezco de una pereza harto general para pasar en limpio mis cosillas ...

Sin embargo, en este caso tengo un placer especial. Repare Ud. en que he hecho letra tipo de imprenta. Puede hacer publicar estas composiciones donde le guste.

La carta dio sus frutos de inmediato. El 26 de abril de 1930, la sección «Poemas» del № 205 de la revista Claridad, trajo tres poemas de Juan L. Ortiz. En ese mismo número, la revista dirigida por Antonio Zamora publicó el poema «Pobreza», de Salvadora Medina Onrubia; el cuento «El pobre», de Álvaro Yunque; poesías de José Portogalo y Evaristo Carriego, y una polémica de Cesar Tiempo. El espíritu de grupo, el alto tiraje, y el alcance nacional de la 
revista, ayudan a dimensionar la importancia que pudo haber tenido este espaldarazo en Ortiz.

La publicación de los poemas corresponden al período de maduración del poeta tenía treinta y cuatro años, y estaba a solo tres de publicar El agua y la noche, su primer libro-. El primer poema que se presenta, «En una claridad de rosa muerta», es un soneto. Llama la atención porque no existen poemas con formas fijas en su obra editada en libros. Hasta ahora se había pensado en un prolongado período de repliegue del poeta, desde aquellos poemas combativos anarquistas. Un tiempo donde Ortiz ensaya una y otra vez diferentes formas y juega con la herencia modernista del metro fijo para luego borrar esa huella y hacer fluir una poesía libre, sin metro ni rima, en su inaugural El agua y la noche. «En una claridad de rosa muerta» se conoció por la edición de la Obra Completa, y según Sergio Delgado se hallaba dentro de un cuaderno encontrado entre sus papeles, testimonio del silencioso trabajo del poeta por encontrar su voz. La realidad es que aquella búsqueda quedó plasmada en las páginas de Claridad, una de las grandes revistas de izquierda de la época. El cambio que supone esto es sustancial: no hubo tal juego cerrado, ni, en principio, fundamentalismo de la forma libre, sino más bien el mecanismo usual de ensayo y error. El tema del soneto, lo que dice, es ya enteramente orticiano; pero es fácil advertir, en una lectura atenta, que el poema se resiente con la disminución léxica a la que obligan el metro y la rima. Se producen quiebres en la sonoridad, aparecen palabras demasiado pesadas para la levedad del motivo. El contraste de eficacia poética con los dos poemas que le siguen, «Se extasía sobre las arenas» y "Los ángeles bailan entre la hierba», de forma libre, es notorio.

Estos últimos pasarán a formar parte de El agua y la noche. Aparecen juntos, promediando el libro, pero en el orden inverso al que lo hacen en Claridad. Anticipan, por forma y tema, el tono general de la obra de Ortiz. 
El único poema que ronda lo social de este conjunto es «Los ángeles bailan entre la hierba», cuya apelación a L'Ange Heurtebise de Cocteau, de 1926, cifra buena parte del mensaje. Si bien comparte con la poesía convencionalmente social el tema - en este caso, el frío y los desposeídos-, Ortiz se aleja de la función didáctica o identificatoria de ésta:

Los Ángeles Bailan Entre La Hierba...

Los ángeles bailan entre la hierba.

Ondula un frío que relampaguea

y que cortaría la tarde.

La tarde dura come un diamante

que desvalora de pronto una nube efímera.

Los ángeles de Cocteau sentados en las cornisas

miraban caer la tarde con ojos violetas...

Es dura la vida - La vida es triste.

Como un mar

la muerte viene del Sur y anda en el sol.

Los ángeles bailan entre la hierba

y sonríen con una sonrisa filosa,

un poco lúgubre, ¿cierto?

Sí, lúgubre y breve. (Claridad sn) 
Lo que resulta llamativo es el contraste que, a pesar de ser un poema social, provoca dentro de la misma página doble de la revista. «Barrio de la pobreza que ya linda/ con la miseria; barrio de muchachas/ que, atadas a la rueda del trabajo, / sueñan con un muchacho que las quiera/ y que por todo lujo les dé besos», canta en esa misma página el ignoto López de Molina en la estrofa final de «Barrio de la Boca» (López de Molina Claridad sn).

Como un arco que tensiona la década de 1930, están por un lado estos poemas, aparecidos meses antes del golpe de José Félix Uriburu, y por otro la recepción de La rama hacia el este, publicada en el no 344 de Claridad, en el mes de octubre de 1940:

Si bien Juan L. Ortiz ocupa un puesto destacado entre la generación penúltima de poetas argentinos, su obra se distingue de la de éstos en que se nutre de esencias más puras, menos artificiales, que la alejan de ellos para acercarlo a las expresiones que se manifiestan en los de la última promoción. Pero, sin duda, la lucha que se entabla en él por definirse de un modo más categórico, es el signo que distingue su manera actual.

Después de un cuarto libro publicado, creo que cabe decirle esto a Juan L. Ortiz, sobre todo si, como creemos, hay en él un auténtico poeta, y en sus versos un material poético de incuestionable valor. Son los poetas prosaistas los que más daño han hecho entre nosotros a la poesía. Junto a una Storni, un Fernández Moreno. O, peor aún, un Nicolás Olivari. Esas dulzuras fáciles y turbias siguen pesando en la poesía de quienes, como Ortiz, tienen la voz dispuesta para expresar acentos más profundos y transparentes. Junto a: "Marzo de pensamientos y de pálidas nieblas viene, 
vino ya", se le oye decir: "Perdón por esta debilidad mía por marzo, poetas amigos y sencillos compañeros."

Ortiz tiene la obligación de volver definitivamente la espalda a las "fuerzas obscuras" (es un juego irónico con el último poema del libro, que se titula "Las fuerzas oscuras") que tratan de arrastrarlo por caminos resbaladizos e infecundos. (Claridad 447)

La lectura que Claridad hace del cuarto libro de Ortiz interesa porque es sincera, cruda, y porque además de asentar sus propias posiciones - reponiendo la idea boedista de transparencia y fácil entendimiento para la poesía social—, permite visualizar el lugar destacado de Ortiz dentro de su generación. Les enoja el desvío que supuso este libro al respecto de los muchos más claramente politizados El alba sube, de 1937, y El ángel inclinado, de 1938.

\section{Ortiz en la AIAPE}

El 28 de Julio de 1935, el núcleo de intelectuales de izquierda que rodea revistas como Claridad y la ya extinta Contra, sumados a grupos de diversa extracción ideológica ligados a las izquierdas del momento (Partido Comunista Argentino, Partido Socialista, Partido Demócrata Progresista y sectores del radicalismo, principalmente), realizan una experiencia de asociación inédita en el país. Tomando, como ya se ha indicado anteriormente, el modelo del Comité de Vigilance des intellectuels antifascistes (CVIA) de París, fundan la Asociación de intelectuales, artistas, periodistas y escritores (AIAPE). El primer presidente y principal impulsor es Aníbal Ponce, quien según el relato del historiador Ricardo Pasolini (2007), «había regresado de su tercer viaje europeo en mayo de ese mismo año, y había establecido 
allí múltiples relaciones con los intelectuales antifascistas franceses, entre ellos Barbusse» (70). El internacionalismo, en términos de apropiación de debates librados principalmente en Europa, será una de las características centrales de la AIAPE, y el talón de Aquiles al que rápidamente apuntaran sus críticos. En un sentido solo aparentemente inverso, la fisonomía de la asociación se vuelca hacia el interior del país, vinculando ciudades y provincias históricamente relegadas en el ámbito intelectual. Crean una editorial y comienza a publicarse el órgano de la asociación, la revista Unidad, que cuenta primero con la dirección de Héctor P. Agosti, y luego, al caer este preso, con la de Rodolfo Puiggrós. Los plásticos crean su propio departamento, dirigido por Lino Eneas Spilimbergo y la escultora Cecilia Marcovich; Antonio Berni, por poner otro caso, es parte del grupo, y muchas de sus producciones acompañarán las publicaciones de la AIAPE.

Para esa misma época, el avance del fascismo en el interior de Alemania y sus funestas consecuencias, posibilitado por la negativa del PC de crear un frente único con los socialistas, había provocado un cambio radical de estrategia de la Internacional Comunista. Las resoluciones del VII congreso de la IC, en 1935, apuntan a fomentar las alianzas y a generar un consenso amplio de colaboración para frenar el avance del fascismo. De allí que el P.C.A. no haya dudado en colocar a sus principales cuadros intelectuales, Puiggrós y Agosti, a disposición de la AIAPE. La siguiente declaración aparecida en el número 1 de la revista Unidad, deja en claro que si bien la AIAPE no es el PCA, el partido vehiculiza a través de aquella su nueva estrategia de frente popular en el área de la cultura:

El Frente Popular es hoy por hoy la única esperanza de derrotar al fascismo, que va por la huella de la muerte social, de la guerra y del hambre, es la única fuerza que puede oponerse con éxito para la defensa de la cultura. Por eso la 
AIAPE apoya el Frente Popular que se está formando en la Argentina y se dispone a colaborar para que sus compañeros los intelectuales, artistas, periodistas y escritores se unan en la lucha de masa contra el fascismo. (Unidad 15)

Pero hay algo más, y no es un detalle menor. Este acercamiento voluntario, buscado, urdido, del PCA hacia los partidos opositores al régimen conservador, cuya pieza más codiciada es la UCR, se llevará a cabo fomentando al interior de las propias filas, a través de los órganos de difusión, una inédita preocupación por los destinos de la patria, anclada en una línea de pensamiento histórico nacional de matriz liberal, que reivindica la línea de Mayo-Caseros en defensa de la independencia.

La distancia proverbial que separa esta apertura de la anterior estrategia de clase contra clase, no escapa a ninguno de los estudiosos de esta etapa de la vida política argentina. «El estalinismo apoya a Alvear», titula Abelardo Ramos (1990) no sin ironía, pero sin faltar a la verdad, su capítulo sobre esta etapa de la historia del PCA (17). Las distintas publicaciones periódicas de la AIAPE, en ese marco, son una apropiada herramienta de difusión para el partido, ya que cuenta con el aval y la pluma de un amplio espectro de intelectuales y escritores no necesariamente miembros, lo cual prestigia y amplía la llegada de esas nuevas preocupaciones y debates a sectores no radicalizados. Pero la colaboración es mutua, ya que el partido aporta la experiencia, las redes nacionales de sociabilidad y el trabajo de sus mejores cuadros para difundir a toda una nueva camada de escritores, intelectuales y artistas, a los cuales, por otro lado, no presiona ni estética ni ideológicamente en ningún sentido. Entre ellos, en un lugar destacado, aparece la figura de Juan L. Ortiz. 
Su obra, principalmente los poemas políticos de las década del 1930 y $1940-$ presentados como testimonios de los conflictos de la época - serán publicados en los órganos de la AIAPE (Nueva Gaceta y Unidad); se le pagará por la escritura de relatos en prosa (Nueva Gaceta, Columna); formará parte del comité editorial (Nueva Gaceta, segunda época), y finalmente, cosa que da la pauta de su lugar en esta asociación, se editará, bajo el sello editorial de la AIAPE, su cuarto libro de poesía, La rama hacia el este, de 1940.

No hay antecedente de estudios o trabajos realizados que liguen a Ortiz con la AIAPE. Tampoco material relevante sobre la relación entre la AIAPE y la literatura argentina (Roberto Arlt, Tuñón, Yunque y Tiempo, entre muchos otros escritores, participaron activamente en ella). Entendiendo a la AIAPE como una inédita experiencia grupal de asociación, con un alto nivel de expansión sobre territorio nacional, con capacidad de romper la centralidad porteña y poner en movimiento y en contacto puntos distantes del país. En este sentido, es pionera la investigación del historiador Ricardo Pasolini, quien estudia en detalle la biografía de un intelectual comunista de Tandil, Juan Antonio Salceda. El vaso comunicante de la AIAPE hará que lleguen a esa localidad importantes artistas y escritores del momento, y brindará una proyección de la figura de Salceda sobre el territorio nacional, a través de publicaciones y conferencias, que lo terminan afirmando como un referente cultural para Tandil, por el hecho, nada paradójico si se conoce la lógica pueblerina, de haber trascendido las barreras de su ciudad para obtener reconocimiento en otras latitudes.

Las relaciones de Ortiz con varios de los escritores e intelectuales que forman la AIAPE es anterior a 1935, tal como lo demuestra el vínculo con la revista Claridad en 1930. A partir de 1935, Juan L. Ortiz militó, tal como lo denunciara José María Rosa, en la filial de Gualeguay de la AIAPE. La correspondencia que mantuvo con César Tiempo - quien le 
propuso la entrada a la asociación, y quien pasó luego a dirigir la revista Columna-, da cuenta del intercambio, y devuelve, de Ortiz, una imagen por lo menos novedosa, vinculada al oficio de la escritura. En un pasaje de una de esas cartas que se conservan en el Archivo «Cesar Tiempo» de la Biblioteca Nacional, fechada el 30 de octubre de 1937, escribe a Tiempo: «Le remito adjunto una pálida narración para su revista. Le pido vigile las pruebas, y de serle posible, me envíe algo por ella, si usted la estima cotizable, pues mi viaje y mis necesidades informativas, dado el atraso de los sueldos (4 meses) me deslizan hacia una seria ruina económica» (Carta a Cesar Tiempo. 30 de octubre de 1937).

Tres meses más tarde, en enero de 1938, aparece publicado "Martín». El relato mantiene una estrecha relación con su poema «El río todo dorado», poema de El ángel inclinado, de 1938, al cual parece donar parte de la historia, el clima y el espíritu de la reflexión poética: no poder observar el paisaje inocentemente mientras haya miseria. Hay, incluso, párrafos donde el ritmo se acerca notoriamente al verso; o, mejor dicho, donde una intención poética tensa la prosa, lo cual lo convierte - frente al conjunto de los relatos de Juan L. Ortiz incluidos en la Obra Completa - en una de sus más logradas realizaciones.

Si a la acuciante situación económica denunciada por el poeta se suma la miseria descripta sin medias tintas en la narración, se tropieza con un panorama sombrío, que, al parecer, no se aleja mucho de lo que se vivía por entonces. Basten las palabras de otro Ortiz, Roberto Marcelino Ortiz, el presidente de la Nación, en ocasión de la apertura de las sesiones parlamentarias de 1938, donde relató las impresiones de su reciente viaje por el Litoral: «Poblaciones enteras carentes de medios de vida indispensables. Hogares casi sin esperanzas, donde los niños crecen desnutridos o enfermos. Niños que no pueden concurrir a la escuela porque carecen de alimentos y de la vestimenta necesaria para cubrirse con 
decencia. Juventudes invadidas por la tristeza y el desaliento» (Halperin Donghi, La argentina 177-178).

De la miseria efectiva al miserabilismo estético que era moneda corriente en las publicaciones de izquierda, había un paso que Ortiz no estuvo dispuesto a dar en su poesía —salvo excepciones iniciales como el mencionado «El río todo dorado» o «Estos hombres...»- pero sí en su narrativa. Esta hipótesis se aborda con el detenimiento necesario en el Capítulo 2 de esta tesis.

Volviendo al itinerario, la primera vez que aparece el nombre de Ortiz en una revista orgánica de la AIAPE es en la reseña que escribe Carlos Serfaty de El alba sube para la revista Unidad, en agosto de 1937. Es la segunda época de la revista, Héctor Agosti está preso en Devoto y la dirección está a cargo de Rodolfo Puiggrós. La reseña de Serfaty puede leerse íntegra en el Apéndice.

En 1940, la AIAPE le publica a Ortiz — tal como ya se indicó- su cuarto libro de poemas, La rama hacia el este. Héctor Agosti, Rodolfo Puiggrós, Raúl Larra, José Portogalo, Gerardo Pisarello y Bernardo Kordon, son otros autores vinculados al PCA que comparten este sello editorial con Ortiz.

Con renovado ímpetu luego del gigantesco traspié que significa para el movimiento antifascista la caída de la República española en el 1939, la AIAPE comienza a publicar en mayo de 1941, y por el lapso de dos años, hasta el golpe del 1943, una revista llamada Nueva Gaceta. Incluye secciones de política, literatura, ensayos y pintura. Pablo Neruda, Raúl González Tuñón, Henri Barbusse, Cesar Tiempo, Álvaro Yunque, Córdoba Iturburu, Agosti, entre muchos otros, son los nombres que aparecerán habitualmente en ella. En la página 2 del primer número, inaugurando el espacio de la poesía - lo que puede leerse como el establecimiento de una línea - aparece el poema «La noche pálida tiembla» de 
Ortiz. En esos versos, que retornarán con variaciones en el libro El álamo y el viento recién en 1947, Ortiz liga de una manera sutil el hambre y el frío cercano a la injusticia de la guerra europea, para culminar de esta manera: «Alma mía, sobre el viento y la noche, mira, mira el bosque de brazos que sostendrá el día puro». (2)

Ese «día puro» contrasta con la noche fría. El cuadro truculento y conmovedor de Antonio Berni, «Medianoche sobre el mundo», que ilustra la portada del no 5 de la revista, es una versión gráfica de esa misma metáfora, donde la noche representa el avance del fascismo.

En la p. 5 del no 9, de octubre de 1941, con ilustración de Andrés Calabrese, Nueva Gaceta publica el relato «Luisa». Ortiz narra allí las visiones de felicidad que tiene en pleno día una adolescente huérfana, que a causa de su pobreza ha sido entregada a una familia rica. Luisa se prueba a escondidas un vestido y un anillo que saca del negocio donde trabaja, y al ponérselo divaga con la mente imaginándose de paseo en un domingo pleno junto al río. La madrastra, que es también la dueña — obesa, burguesa y repugnante- la descubre. El cuento termina abruptamente, un momento antes de que se produzca la golpiza.

En mayo de 1942 aparece en Nueva Gaceta el poema «Los mundos unidos (El hospital Palma)». Allí establece un contraste entre una visión de Paraná y de las islas y la miseria del hospital, de los locos, los viejos y los paralíticos. Y otra vez aparece la guerra: «El horror sangriento en casi todo el planeta, / pero atravesando el horror de un alba aún pálida que avanza en las liberadoras bayonetas del Este» (2). El «Este», en ese contexto, es la Unión Soviética.

Lo que lleva directamente al último poema de Ortiz que aparece en Nueva Gaceta, en el mes de agosto de 1942, titulado «22 de Junio (Para los poetas de la rosa y de la mariposa)». Esa fecha del título, que hoy es una referencia perdida, representa uno de los 
golpes más importante de la historia de la supervivencia del comunismo en Unión Soviética. El 22 de junio 1941, en primavera, se produce la sorpresiva invasión del Tercer Reich sobre el territorio soviético, conocida como «Operación Barbarroja». Las sanguinarias batallas que se libran, y que encuentran a un Ejército Rojo desconcertado, representan el rompimiento de manera unilateral por parte de Alemania, del famoso pacto «Molotov-Ribbentrop», con el que trascendió el acuerdo de paz celebrado en 1939 entre Adolf Hitler y Josep Stalin.

Este poema de Ortiz tiene, de cara a las implicancias del título, un comienzo potente: «Ellos también, poetas, defienden nuestros sueños./ No es acaso la poesía visión en que esta fiebre de formas que es la vida/ ilumina de pronto las todavía trémulas y tiernas figuras por nacer? Pensáis que una lívida muerte de hierro sobre el sueño/ os podrá permitir decir la rosa, decir el vuelo de la mariposa?». (7)

Este es el modo en que Ortiz advierte que la amenaza que se abre el 22 de junio no toca tan sólo a los comunistas, sino a todo el universo de la cultura. Y continúa, en otro fragmento: «La poesía fue nostalgia, mis amigos, / de la comunión que ahora sabemos cómo florecerá. / A pesar de ella misma fue nostalgia. / Por eso el hierro lívido quiso encerrar la brisa/ y el estúpido fuego hacer cenizas de la más delgada agua de la melodía». La historia de la poesía se liga en la continuidad del poema a la historia de la Revolución Rusa, al sueño de la revolución realizada:

Y el sueño fue como un viento que madurara en las ciudades, en las aldeas / y en los campos.

Y sobre la primavera del sueño se abatió la tempestad del hierro el/ 22 de Junio.

Y los brazos que sostenían el sueño le hicieron un blindaje de muerte/ 
contra la tempestad.

Y la estrella de cinco puntas fue un ubicuo terror para el terror / gamado.... (Nueva Gaceta 7)

Este poema condensa la visión de Ortiz que vincula a la poesía con las condiciones sociales necesarias para su producción y circulación. Y resulta, a la vez que uno de los puntos más altos de su poesía política, y quizás por ese mismo motivo, su poema más difundido dentro del circuito comunista.

Ortiz en el Cancionero de la Guerra Civil Española

En Montevideo, que contaba con una activa filial de la AIAPE, se editaron en 1937 dos antologías en apoyo a la causa republicana: Poeta fusilado y Cancionero de la Guerra Civil Española.

Este último cancionero, cuya edición estuvo a cargo de Ildefonso Pereda Valdés, contó con la participación de varios poetas argentinos; entre ellos, Carlos Mastronardi y Juan L. Ortiz. Ninguno de los dos incluyó posteriormente en sus libros las piezas que enviaron a la antología. El poema de Ortiz «A los poetas españoles», fechado en 1936, permaneció en el olvido hasta que fue recogido por otra antología, Voluntarios con gafas. Escritores extranjeros en la Guerra Civil Española, editada por Niall Binns en Madrid, en el año 2009.

Que el poema haya quedado fuera de En el aura del sauce, puede deberse, se conjetura, al modo esquemático en que aparecen los elementos constitutivos del diálogo poético, es decir, el paisaje y la injusticia. Hay una cierta precipitación e insistencia en el contraste, muy patente en el comienzo: 
Jardines aquí,

dicha florecida aquí,

sobre el dolor oscuro aquí,

entre la injusticia y el dolor aquí.

Pero la angustia, la sangre,

la muerte, qué sombra hacen

sobre la efímera, frágil luz

de nuestra tierra,

de todos los paisajes de la tierra

donde hay corazones que laten

con el latido esperanzado y angustiado del mundo! (A los poetas españoles

sn)

Apreciación que se acentúa si se pone a «A los poetas españoles» en relación con otros momentos de la poesía de Ortiz que, contenidos en El alba sube, de 1937 y El ángel inclinado, de 1938, es decir, libros contemporáneos a los sucesos de la Guerra Civil Española , manifestaron una elaboración notoriamente más refinada del mismo tópico.

Ortiz adoptó en sus poemas de la Guerra Civil Española, con plena conciencia del campo literario en que se movía - donde figuraba España 1936, de Álvaro Yunque; pero cuyo centro, indudablemente, estaba ocupado por La rosa blindada, de Raúl González Tuñón-, una forma experimental de retaguardia combatiente. El desarrollo de esta hipótesis sobre la obra de Ortiz en el contexto de la producción poética alrededor del conflicto de España, tiene lugar en el capítulo siguiente. Pero el hecho de que un poema 
suyo figure en las antologías mencionadas (la original uruguaya y la reciente de Niall Bins) permite, como el resto del itinerario presentado aquí, ubicar su figura y su producción en conexión con el universo comunista.

La revolución de Mayo y los deberes de la inteligencia

En la víspera del 25 de mayo de 1942, el diario El Litoral -el más importante de la ciudad de Santa Fe y sus alrededores- publicó a página completa una serie de artículos conmemorativos sobre la Revolución de 1810, invitando a algunos intelectuales de la región a volcar sus reflexiones. Lo llamativo del caso son las firmas: dos poetas y escritores entrerrianos ligados al comunismo criollo, Amaro Villanueva y Juan L. Ortiz, y un español exiliado luego de la caída de la segunda república en manos de Francisco Franco, el poeta Francisco Ayala. Fueron las vinculaciones de El litoral con el Partido Demócrata Progresista, de origen santafesino, y las de éste último con el Partido Comunista - que estando proscripto y bajo la estrategia de Frentes populares - lo apoyó en las elecciones presidenciales del 1936, las que abrieron las puertas del diario a estas firmas.

El artículo que escribe Juan L. Ortiz se titula «Mayo y la inteligencia argentina». Se cita uno de los pasajes finales:

La inteligencia argentina tiene así ahora una doble responsabilidad militante y creadora: la del resguardo y la ampliación de las conquistas logradas con tanta sangre y sacrificios y la de promover, con la acción, el pensamiento y la sensibilidad unidos, el nacimiento de nuestra alma hecho una sola cosa con nuestro paisaje y nuestras gentes. Sólo así seremos dignos de Moreno y de 
Echeverría, de Gutiérrez y de Hernández. Mayo sigue siendo una gran responsabilidad para quienes sienten que la patria es una cosa en marcha que nos exige cada día mayores sacrificios y sobre todo un sentimiento más fino y fuerte de una continuidad histórica, abierta sobre una perspectiva ilimitada de justicia y de belleza para todos. (1055)

Sergio Delgado, editor de la Obra Completa y sin dudas el mayor experto en la poesía Ortiz, ha señalado reiteradas veces la presencia de Mayo como idea de revolución inconclusa en su obra. Y ha creído ver, en este artículo publicado en 1942, la concreción o la puesta en claro de la visión personal de Ortiz sobre el asunto, y las implicancias que este ideal patriótico acarreaba a los intelectuales que se vieran destinados a continuarlo. Incluso llegó a proponer a El Gualeguay, ese larguísimo poema histórico de Ortiz publicado recién en 1970 dentro de En el aura del Sauce, como una respuesta a estas inquietudes (EI Gualeguay).

Resulta sencillo acordar con este último punto. Basta repasar los versos de $E I$ Gualeguay que corresponden al período de Mayo y ligarlo al conocimiento minucioso que Ortiz tenía de la historia entrerriana, con sus caudillos y sus procesos, para comprender que la razón histórica tiene un peso importante en esa obra. Y en otros poemas suyos también. El punto, o lo que cabe destacar, es que la continuidad de los ideales de Mayo, así como los deberes de la inteligencia para con su realización, de ninguna manera representan el pensamiento individual de Ortiz, sino más bien su adhesión, en términos militantes, a las consignas difundidas por el comunismo local. Mayo, así como los deberes de la inteligencia son tópicos comunistas de finales de la década de 1930 y principios de la de 1940 . El modo en que estas ideas penetran y se reproducen en la obra de Juan L., funcionando como un 
verdadero motor, transfigurándose, representa una de las más fructíferas resoluciones de la siempre tensa relación entre poesía y política de todo el siglo XX en la literatura argentina.

Frente al fraude y la persecución de los gobiernos del régimen conservador, y frente a lo que los comunistas creyeron ver en el golpe del 1943, y en el surgimiento del peronismo —al que entendieron en primera instancia en términos de naziperonismo, o, más significativamente, como una reactivación del caudillismo feudal rosista - la historia de matriz liberal funcionó como un dispositivo eficaz de difusión de los ideales democráticos en un sentido amplio.

Por fuera de esta coyuntura, es reveladora la deriva que describe la cuestión de Mayo para terminar siendo enarbolada por los comunistas criollos. Una saga que comienza en el año 1918, con la publicación de Las evolución de las ideas argentinas, de José Ingenieros. El interés militante del autor a favor de las ideas de la revolución de Mayo, queda declarado desde la misma «Advertencia del autor»:

¿Conviene que la nueva generación argentina medite sobre esos problemas y tome conscientemente posiciones por el pasado o por el porvenir? De eso se trata: de completar mediante grandes reformas el nuevo régimen iniciado por la Revolución o de resistir su advenimiento conservando los residuos del antiguo régimen. Son dos filosofías, dos sistemas de ideas generales. Toda política que lo ignore, pasada esta hora sombría de la historia mundial, será un ciego andar a tientas, sin rumbo y sin esperanzas. (8)

En la conceptualización del cuadro que la caducidad de la monarquía peninsular generaba en Buenos Aires, Ingenieros juzga - lo que devendrá en marca indeleble- la solución política planteada por Mariano Moreno como de extrema izquierda: «Revolución inspirada 
en la filosofía política del siglo XIX, pasando el gobierno a manos de los nativos y dirigida a subvertir radicalmente las instituciones coloniales. Partido de una exigua minoría argentina...» (135)

El siguiente paso lo da Aníbal Ponce, quien fuera uno de los principales discípulos de José Ingenieros. Son fundamentales dos conferencias suyas, luego reunidas en libro. La primera es «Examen de conciencia», pronunciada el 19 de mayo 1928 en la Universidad de La Plata con motivo del aniversario de Mayo. Sin dejar de lado la hipótesis de Ingenieros, entendiendo la revolución como tarea de minorías iluminadas - lo cual lo lleva a establecer una oposición entre "europeos puros o casi europeos», que habrían hecho la revolución y, en la vereda de enfrente, la barbarie gaucha, la aplastante mayoría conservadora-, Ponce introduce un vínculo que terminaría siendo central en los discursos de la izquierda comunista del período estudiado sobre el tema, el nexo entre los ideales de la Revolución de Mayo y los de la Revolución Rusa: «Los ideales de la Revolución Rusa son, de esa manera, los mismos ideales de la Revolución de Mayo en su sentido integral; y si Echeverría hubiera presenciado su advenimiento, lo habría reconocido con el mismo alborozo con el cual setenta años atrás vio, en el movimiento socialista del `48, "una de esas revoluciones fáusticas - son sus palabras - que inician una nueva Era en la vida de la humanidad"» (2526)

La segunda conferencia a la que se hacía referencia la pronunció Ponce unos pocos meses antes del golpe del Uriburu, en la Facultad de Ciencias Económicas de Buenos Aires. Llevaba por título «Los deberes de la inteligencia». Se trata de una conferencia con amplias repercusiones en el campo de la izquierda durante la década de 1930. Su tema es siguiendo la idea de una minoría que guía los destinos patrios -, reactualizar la agenda de los deberes de esa minoría y alinearla con los grandes pensadores occidentales, invitando a 
que ésta tome la responsabilidad de guiar o inspirar, esta vez, la revolución socialista: «Ya no más la inteligencia que encuentra en sí el propio gozo: ¿de qué modo comparar su placer egoísta con el estremecimiento generoso del profeta que alza una esperanza nueva, del predicador que la desparrama y la vivifica, la multiplica en las almas, la enciende en los corazones?» (39).

Sin embargo, los deberes de la inteligencia no debían malinterpretarse:

No desdeñéis tampoco el arte y la belleza — pronunciaba Ponce en 1930-, ni os deslicéis a la exigencia absurda de querer socializarlos [...]Marx, que admiró a Heine con entusiasmo de artista, y que había escrito en la juventud sus buenos tres cuadernos de poesía, entendía que a los poetas había que dejarlos marchar libremente por la vida y que no se los podía medir por el rasero de otros hombres; no había más remedio que mimarlos un poco, si se quería que cantasen; con ellos, no valían las críticas severas. (42-43)

El eslabón siguiente es Héctor P. Agosti, confeso discípulo de Ponce. Quien no solo escribió una biografía intelectual de su maestro titulada Aníbal Ponce, memoria y presencia, sino que llevó a cabo la tarea que, según su relato, éste le encargó, de realizar la biografía intelectual de José Ingenieros. Cosa que efectivamente hizo y publicó en 1944, con el título de José Ingenieros, ciudadano de la juventud. Fue Agosti quien le dio a las ideas de Ponce transformándolas, por supuesto- entidad partidaria. El análisis de historiografía militante que corresponde al PCA sobre la cuestión de Mayo lo realiza Rodolfo Puiggrós. Pero en el terreno de la cultura, de las artes, de la crítica literaria vinculada al Partido, ese lugar le corresponde a Héctor P. Agosti. 
Ha sido Agosti, asimismo, quien con mayor claridad ha exhibido las limitaciones de una adopción ingenua de la matriz liberal al interior del comunismo. Un hecho externo al PCA, como lo es el mencionado cambio de rumbo que el VII Congreso de la Internacional Comunista de 1935 impuso a nivel global, puso en el centro de la escena esta cuestión, en el sentido que el PCA necesitaba una plataforma común de diálogo con los partidos liberales para realizar el frente popular democrático que funcionara como barrera de contención frente al avance mundial del fascismo. Agosti se encargó de hacer evidente la filiación, pero también la diferencia:

Defendemos, con la energía que los hechos han demostrado, la línea de la tradición democrática argentina, lo que se llama la "herencia de Mayo", y allí están para probarlo los trabajos críticos de tantos camaradas nuestros, no sólo en el campo de la literatura y la historia, sino también en el de la economía y la ciencia; trabajos que no se limitaron a la exégesis sino que procuraron trasladar al pueblo las lecciones eminentes. Sin embargo, aun coincidiendo con buena parte de la intelectualidad argentina en esta defensa de la tradición de Mayo, nos diferenciamos de la intelectualidad liberal justamente porque apreciamos las contradicciones de clase que laten en el pueblo de Mayo, porque no damos a su rememoración carácter estático, porque comprendemos que Mayo fue el anuncio de una revolución democrática que debemos cumplir en las nuevas condiciones del mundo. No renunciamos a los soportes históricos, pero sabemos que esa línea se ejercita en una continuidad histórica de acento antimperialista, rumbo abierto por José Ingenieros y Aníbal Ponce que a nosotros nos toca proseguir. Nuestra 
misión, por lo tanto, no consiste únicamente en defender esa línea tradicional sino en crear las bases de una nueva cultura, lo que otra vez nos enfrenta con la Función de la ideología. (Para una política de la cultura 28)

Como se ve, el modo en que la clave de Mayo y los deberes de la inteligencia funciona en la obra de Ortiz, no puede comprenderse en su sentido íntegro por fuera de esta tradición, del dialogo constitutivo del poeta con la intelectualidad comunista argentina.

\section{Ortiz, poeta comunista}

En 1943, el prolífico narrador, poeta, dramaturgo y ensayista Álvaro Yunque - seudónimo de Arístides Gandolfi Herrero- publicó a través de la editorial comunista Futuro una antología de poesía argentina, Poetas sociales de la Argentina (1810-1943), que en cierta forma complementaba su volumen de ensayos La literatura social en la Argentina, de 1941, editado a través Claridad. A poco de comenzar el prólogo, Yunque expone sus intenciones: «Este no es un libro ecléctico. Es un libro militante. Un libro de su momento. El poema sin inquietud ideológica se ha excluido de él, deliberadamente, tan deliberadamente como de las "antologías" habituales se excluye el poema con inquietud ideológica» (Poetas sociales 9).

Los poetas son agrupados por Yunque siguiendo una cierta progresión: «Poetas anónimos y gauchescos», "Poetas idealistas», «Poetas anarquistas», «Poetas socialistas», «Poetas de diversa inquietud», "Poetas de Boedo», "Otros poetas de diversa inquietud», «Poetas del descontento campesino», «Poetas Judíos», y finalmente, «Poetas comunistas». 
La relación que se establece entre estos grupos sigue, en buena medida, el patrón de antecedente/realización, en cuyo avance paulatino explícitamente se pondera, por encima de los otros poetas sociales, la voz de los «poetas comunistas».

La escueta nota biobibliográfica de Juan Ortiz — cuyo nombre aparece así, sin la «L.» usual - se limita a indicar su lugar de nacimiento, Gualeguay, y los cuatro libros publicados por él hasta ese año. Sin embargo, Álvaro Yunque escoge un poema que no se encuentra en esos libros. Tampoco es inédito: ha circulado entre los comunistas el año anterior y su actualidad, siendo que la Segunda Guerra Mundial no había concluido, era palpable y dramática. Se trataba - como se puede haberse inferido ya- del poema « 22 de Junio».

A este hecho que consagra de por sí la ubicación de Ortiz dentro del universo de los poetas comunistas, hay que agregarle la conferencia que Héctor Pablo Agosti le dedica al autor en 1939, incluida luego con el título «La poesía de Juan L. Ortiz» en el capítulo 4, «La poesía y nuestro tiempo», del libro Defensa del realismo, de 1945. En dicho capítulo Agosti examina solo dos poetas: Juan L. Ortiz y Raúl González Tuñón. Y en ese orden.

Las resonancias del sugestivo -y muy temprano- análisis de Agosti sobre la obra de Ortiz se estudian en el capítulo siguiente. Baste, para concluir el presente, dedicado a la constatación de datos, publicaciones y vínculos partidarios del poeta, citar algunos pasajes del ensayo de Agosti insistiendo una vez más en su valor testimonial. Pues señala el momento en que la poesía y la figura de Ortiz es consagrada y defendida, con toda su complejidad inherente, por el más destacado crítico literario y cultural del PCA del período. Escribe Agosti:

El poeta advierte la anarquía de este mundo en que le ha tocado nacer y debatirse a su poesía. Pero el poeta verdadero, aun sintiendo en toda su 
grandeza el drama de los hombres, tiene el encargo de responder a los llamados de la vocación. No hacerlo fuera defraudarse a sí mismo y traicionar, al propio tiempo, su más porfiado y doloroso servicio social. Y hay que afirmarlo con suficiente reiteración, porque en el tiempo de la pelea el poeta suele cosechar la sonrisa desdeñosa de algunos "prácticos" a todo trapo. Pues si no es el tiempo de detenerse a recitar versos de amor mientras la metralla canta sus letanías sobre las ciudades abiertas, también será siempre repudiable estupidez de filisteos proclamar la inutilidad de los poemas y de los poetas.

Y continúa, definiendo ya no solo el lenguaje de Ortiz, sino el lugar que ocupa su poesía:

Aludo repetidamente a este lenguaje de Ortiz porque su valor procede directamente de él mismo, de su desnudez no empañada por ninguna trampa de oficio. No hay en Ortiz ni los viejos juegos retóricos ni el brillante oropel técnico, frecuentes ocultaciones de la flacura del pensamiento. Su lenguaje es dolorosamente sobrio y severo. Sus metáforas aléjanse del fuego de artificio. En el lento descarnar de sus versos, hasta dejarlos en ese cuerpo delgado y macizo, Ortiz marcha hacia la obtención de un lenguaje depurado, delicadamente conmovedor. No es la suya una poesía para recitativos. No es el verso para cantar, que alguna vez nos anunciara Raúl González Tuñón. Ya lo sabe el poeta, antes que se lo digamos:

Sí, yo sé que un hilo de flauta Es despreciable para vosotros. Que las canciones de marcha son las a vosotros debidas, 
Ahora que es necesario ir, bajo ráfagas de fuego, acaso,

A ayudar a nacer el mundo nuestro y vuestro

Confiesa en El alba sube. (Defensa del realismo 106-113)

Agosti confiere a la poesía lírica, casi elegíaca de Ortiz, un estatus en el plano de la disputa ideológica. Una interpretación insoslayable, tan insoslayable como las razones que la sustentan. Si cabe afirmar que Ortiz instaura al poema, no al prólogo, ni al manifiesto, ni al ensayo, como el lugar donde la poesía se piensa a sí misma, donde piensa su función, donde dialogan sus territorios y se deslizan sus aspiraciones, cabe también afirmar que fue Agosti quien - contemporáneamente- detecta el enorme valor de que tiene que esa apuesta se lleve a cabo, precisamente, cuando la poesía está siendo llamada al combate. 


\section{Capítulo 2: La poesía social de Juan L. Ortiz}

La poesía social entre 1930 y 1940

El fascículo 50 de Capítulo, la historia de la literatura argentina, fue determinante para orientar el rumbo de la investigación de la que da cuenta esta tesis. Se titula «La poesía social después de Boedo» y su autor es Carlos R. Giordano. En esa etapa del Centro Editor de América Latina, el material se sometía a la lectura y el visto bueno de Adolfo Prieto. El fascículo data de 1968 y es el primero en abordar de manera programática, desde el punto de vista de la crítica literaria no partidaria, el vasto panorama de la poesía de izquierda de las décadas de 1930 y 1940. Las tesis que allí esboza Giordano son muy valorables. Así como también su sagacidad crítica al decidir contrastar esta literatura respecto de la desarrollada por el grupo de escritores de Boedo en la década de 1920. Atendiendo incluso a casos que — como el de Ortiz - se apartan de la media. De hecho, el pasaje referido este poeta se presenta como «El caso Ortiz» (Giordano), en una columna separada del cuerpo del texto, reforzando la idea de una tensión entre pertenencia y dislocación. Ortiz no puede ser asimilado ni convertido en emblema de la poesía social argentina, pero, he aquí la hipótesis de Giordano, tampoco puede ser apartado de aquella corriente.

Si Giordano no desarrolla el vínculo partidario del poeta, ni consigna el conjunto de ideas que vinculan la producción de Ortiz con el comunismo criollo, es porque no persigue tal objetivo. Es dable sospechar, a la luz del conjunto de revistas literarias que en ese mismo fascículo aparecen descriptas - buena parte de las que se han citado en el apartado «Ortiz en la AIAPE», en el capítulo anterior de esta tesis-, que Giordano conocía de sobra el 
vínculo. Pero limita su tarea a señalar a Ortiz, en 1968, como un caso de poesía social de excepcional calidad estética.

Esta investigación se sirve, a su vez, del modo en que Giordano aborda el acercamiento la categoría de «poesía social»:

La categoría literaria de poesía social, es decir, la consideración de la poesía de tema social e intención revolucionaria como una suerte de género poético distinto de la lírica y la épica, es teóricamente cuestionable. Sin embargo, el hecho de que en el proceso histórico de una literatura se haya planteado el problema y hayan surgido tendencias que cultivaron esta poesía como distinta y opuesta a otras, obliga a tenerla particularmente en cuenta y a prestarle atención por separado, al menos mientras el problema es sentido como tal por los propios autores. Sin duda, toda obra literaria es expresión de circunstancias políticas, sociales y económicas precisas y determinadas. El arte está vinculado estrechamente, pero de manera complejísima, a la sociedad de que proviene y a la que se dirige para cuestionarla o celebrarla. Lo social condiciona el arte. En una sociedad dividida en clases es lógico que el arte evidencie tal división. La literatura pura no desmiente estas afirmaciones: en general, cuanto más "pura" pretenda ser, cuanto más pretenda desentenderse de su contorno social, más clara resulta como testimonio de una situación humana agobiante e insatisfactoria. Ahora bien, la literatura puede reflejar pasivamente una situación, puede mostrarla a pesar de ella misma, es decir, a pesar del carácter prescindente que su autor ha querido otorgarle; o, por el contrario, la literatura puede ser la expresión 
lúcida y voluntaria de los conflictos que se agitan en una comunidad y atestiguar, además, una postura frente a tales conflictos, una definición ante las opciones existentes. La literatura social está comprometida, por supuesto, en este segundo tipo de literatura.

Giordano abre aquí un interesante paréntesis que complejiza y pone trabas a una utilización ingenua de dicha categoría:

Pero no debe olvidarse que una literatura semejante, al mismo tiempo que es expresión consciente e intencional, es también una mostración de elementos, circunstancias e impulsos que el autor no advierte ni controla. Con terminología de la lingüística podría decirse que la obra de arte es indicio y señal al mismo tiempo. En la literatura social la tensión entre ambos planos puede llegar a ser muy grande; en la medida en que ella no es sólo una formulación ideológica, sino sobre todo una tentativa crítica sobre respecto de las ideologías, y nada garantiza que las correcciones críticas sean totales ni siquiera adecuadamente orientadas.

Finalmente, deriva en una serie de deslindes que, discutibles o no, lo llevan a poner en valor la potencialidad de la expresión lírica:

Sartre ha sostenido que la poesía — como la música y la pintura - no pueden ser comprometida, es decir, que es imposible utilizarla como un medio de acción conforme a las exigencias de su tiempo. Esta afirmación se ajusta a un concepto demasiado estrecho de la lírica. Justamente es lo social 
problemático lo que más ha contribuido a que la poesía lírica, sin por eso convertirse en épica, a la manera tradicional, abra sus estructuras y amplíe sus posibilidades hasta convertirse en la expresión por excelencia de una totalidad. La lírica moderna en su conjunto es, como cualquiera de las otras manifestaciones artísticas, expresión de las relaciones entre individuo y sociedad e historia, y no desde la sola subjetividad del poeta sino en un constante contrastar y aprehender lo objetivo y lo subjetivo. Afirmar lo contrario sería negar a la poesía las posibilidades del verdadero realismo. No es posible distinguir, en una poesía así concebida, lo social de lo político. No se trata de sostener que deba ser necesariamente política, sino de afirmar que de su poesía de intención, tema y tono político no es otra cosa que poesía social en la que se ha acentuado uno de sus aspectos: el de la definición, el de la postura frente a los conflictos y las causas de esos conflictos. (1179-1180)

Este abordaje de la categoría «poesía social» tiene un manifiesto aire de época. La discusión con Sartre es el indicio más claro. Y es deudora de un imaginario conceptual vinculable al universo de la revista Contorno. No obstante, la claridad conceptual y el desgajamiento de la categoría en una serie de ideas sobre la literatura - que incluye puntualmente la cuestión genérica de la lírica en relación a la política一, admiten restablecer la definición y utilizarla como marco de apertura de este segundo capítulo, dedicado al análisis de la poesía social de Juan L. Ortiz.

La posibilidad de pensar separadamente la poesía social le viene a Giordano de la realidad histórica o, más estrictamente, de la materialidad del objeto estudiado: libros, 
revistas, artículos sueltos en los periódicos, cartas de escritores, etc., todo apunta a la existencia de un cuerpo autónomo. La poesía social en argentina tuvo su propia historia, sus propias claves y su propio circuito de legitimación.

En ese sentido es necesario, tal como él mismo lo plantea, incorporar la mirada de ese que se declara distinto, diferente, que testimonia otras claves e intenciones. Lo que se encuentra, para el caso de la historia de la poesía argentina, son libros, ensayos y hasta pasajes de poemas que dan cuenta del reconocimiento de esa tradición. Y será necesario estudiarlos con detenimiento, porque muchas veces allí se encuentra el otro del diálogo de la poesía de Ortiz de este período. En ese horizonte del pensamiento crítico sobre la literatura de izquierda que proponen, entre otros y en simultáneo, Álvaro Yunque, Héctor Agosti y Amaro Villanueva.

Los dos primeros, puestos en combinación, permiten acercarnos a la historia de la literatura argentina en la versión de los comunistas criollos, y en particular a la poesía. Yunque le dedicó un libro de historia literaria completo, La literatura social en la Argentina. Historia de los movimientos literarios desde la emancipación nacional hasta nuestros días, publicado por Claridad en 1941 y una antología en cierto modo complementaria en dos tomos, Poetas sociales de la Argentina (1810-1943), publicado por Editorial Problemas (aquella que dirigía Carlos Dujovne, el editor descripto por Raúl Larra en el testimonio sobre Ortiz). Héctor Agosti, por su parte, trabajó en un nivel más teórico que Yunque. Pero su preocupación por redefinir el concepto de «realismo», de ninguna manera está reñida con el análisis concreto del pasado y actualidad de la poesía social argentina de este último. Villanueva, por último, ocupa un lugar interesante en el contexto producción teórica y de historia literaria propia del comunismo criollo. En sus estudios sobre el Martín Fierro se conjuga la clave de literatura social con efectivos aportes de investigación literaria. Con un 
pie en la saga de estudios tradicionalistas sobre el Martín Fierro, con otro en la novedosa intención de incorporar al Martín Fierro al universo de la literatura comunista, el caso de Villanueva interesa, además de por su peso propio, por la cercanía y amistad que mantiene con Ortiz. Villanueva, a diferencia de Yunque y Agosti, construye su aporte desde Paraná.

Que las producciones de Yunque y Agosti repongan a Ortiz como un autor comunista es, de alguna manera, revelador. Pero interesa ahora, y para ello sirve de marco la definición de Giordano, el diálogo que se establece al interior de su obra. El modo en que el poeta procesa el vínculo con la literaria universal y local, con la tradición y el presente político y, en este punto, con las interpretaciones que sobre estos temas emanan de la usina de pensamiento estético y político del comunismo criollo.

Daniel García Helder escribió un ensayo imprescindible para comprender la poesía de Ortiz. Se titula «Juan L. Ortiz: un léxico, un sistema, una clave» y aparece publicado acompañando las sucesivas ediciones (1996 y 2005) de la Obra Completa del poeta. Helder posa su atención sobre el llamativo vínculo que existe entre una poesía lírica como la de Ortiz - elegíaca, cuya máxima aspiración es la levedad y cuyo tema casi exclusivo es el paisaje- y los conflictos sociales. Escribe:

El sujeto contempla la belleza natural, entre cuyos accidentes de forma y movimiento todavía se perciben, como un remanente de la analogía profunda que debió haber brillado en la superficie durante la edad dorada, ciertas relaciones o correspondencias; la nostalgia de este pasado mítico, sin embargo, no es tan enérgica ni sostenida como la esperanza de un futuro en que se dará la "gran relación" o "comunión total", utopía que a veces parece coincidir con el socialismo, pero que por lo general se presenta de un modo 
abstracto, difuso, cósmico. En el espacio abierto entre ese pasado y ese futuro míticos, el drama del presente contrasta con la belleza natural, interfiriendo su contemplación. Esta conciencia subjetiva de la adveración es el dedo en la llaga de la poesía de Ortiz, cuyo peculiar concepto de la elegía y aun del género lírico se cifra todo en ese pero. (144)

El crítico rescata, para definir esta apuesta estética, un concepto del propio poeta: «Ortiz se muestra entonces consiente de este híbrido al que denominó "elegía combatiente" y para el que su poesía encontró, desarrolló y en buena medida agotó una fórmula muy particular» (García Helder 142). El ensayo de Ortiz del cual toma el concepto de «elegía combatiente» es «El paisaje en los últimos poetas entrerrianos», publicado en Buenos Aires en la revista Davar - cuyo secretario de redacción era Bernardo Verbistky-, № 15, en enero de 1948.

Ese texto de Ortiz es significativo ya que al mismo tiempo que brinda una clave - que Helder sagazmente repone - para comprender su visión del diálogo entre lírica, paisaje y política, revela el nivel de conocimiento que tiene de la tradición y también de la obra de sus contemporáneos entrerrianos. Escribe Ortiz allí, en 1948:

La poesía de nuestra provincia ha tenido y tiene en general caracteres parecidos: ha sido y es armoniosa y clara. También en ella está el agua por una a manera de diafanidad o de vapor tenue, irisado a veces. Asimismo está en ella referimos a la moderna más significativa - lo que el paisaje de Entre Ríos tiene de insular: es en cierto modo una meditación lírica un poco flotante. Por aquí tocamos ese sentimiento de la soledad que se percibe en los poetas últimos, soledad, desde luego, no ya sólo del paisaje natural sino también del paisaje humano o de los mismos poetas frente a este paisaje. $Y$ 
el tono elegíaco que tal sentimiento determina con los matices que supone, dados los distintos temperamentos y las distintas actitudes líricas y personales. Verdad es que toda poesía del interior tiene algo que ver con la elegía, en Entre Ríos y en todas las provincias del mundo, aparte de que la poesía quizás más honda de la época, la más desgarrada y la más serena, aun en sus apelaciones a una comunión respecto de la cual no abriga dudas, tiene bastante aire de elegía. Una elegía combatiente a veces porque también es justicia. (Davar sn)

En línea con Giordano y Helder, Martín Prieto da cuenta de esa zona de intensiones tan particular en la que necesariamente debe colocarse la poesía y la propia figura de Ortiz. En su ensayo «En el aura de sauce en el centro de una historia de la poesía Argentina», Prieto bosqueja un camino que, ya presente en Agosti, al poner en dialogo la poesía social de Ortiz con la poesía social del poeta revolucionario por antonomasia de la literatura argentina: Raúl González Tuñón. Señala Prieto:

Esta poesía, que ligeramente llamamos "social" por sus asuntos y proyecciones, no debe sorprendernos en un autor que sentía una singular admiración por González Tuñón, uno de los "poetas sociales" argentinos más emblemáticos.

“¿Quién da para usted la imagen del poeta?”, le pregunta Juana Bignozzi, y contesta Ortiz: "Raúl, ah, sí, siempre me ha parecido. Raúl González Tuñón". Si nos sorprende, en cambio, es porque lo que entendemos por "poesía social” en la Argentina, desde, justamente, Raúl González Tuñón en adelante, es una poesía de marcado tono urbano y Ortiz prefiere otro modelo, tan 
singular como el anterior, pero verdaderamente menos conocido. Dice en una entrevista a José Tcherkaski, en el año 1969: “La poesía belga era lo mejor que había y es riquísima con respecto a la francesa. No diría más rica, pero es tan rica como puede ser la inglesa, sobre todo en ese sentido que entonces a mí más interesaba, es decir, en el sentido del paisaje, y por otro lado, en el sentido social. Son cosas que parecen contradictorias, pero en ciertos poetas se daban sin choques, o en forma dialéctica si se quiere, o sea, aun chocándose llegaban a cohabitar, a darse, casi a hermanarse por momentos". (Prieto 117)

El modelo que Ortiz encuentra en los poetas belgas en lengua francesa - señalado por Prieto- es índice del elaborado trabajo intelectual del poeta, que cruza e incorpora con plena conciencia las experiencias de poesía social de tradiciones no tan frecuentadas. Este tipo de decisiones nutren su singularidad como poeta social. Hecho que no pone en cuestión su lugar en la sociabilidad comunista. En este sentido, Ortiz no era ningún caso: se movía, como hemos visto, como el resto de sus camaradas. Lo singular no estaba tanto en su figura, por más que se suela insistir en ese punto, sino en su labor poética.

Precisamente allí, en el quehacer de la obra de Ortiz, despliega Carlos Giordano las particularidades de «El caso de Juan L. Ortiz». Se transcribe completo:

Juan L. Ortiz nació en 1897 y publicó su primer libro en 1933. En enero de 1930, César Tiempo y Carlos Mastronardi analizaban su poesía (La literatura argentina, $\mathrm{n}$ ㅇ 17). No es fácil de clasificar, y ha evitado cuidadosamente toda forma de notoriedad. Se trata de uno de nuestros mayores poetas. Su poesía honraría a cualquier literatura. Es capaz penetrar en lo más hondo del paisaje 
natal para entregarnos el secreto del tiempo, de la naturaleza y de hombre. Todo simple y complejísimo, a la vez, en la arquitectura de sus versos. Y sin embargo, es un particular tipo de poeta social. No por su anécdota personal, que revela netas y riesgosas posiciones políticas e ideológicas nunca desmentidas, sino en la propia materia de sus poemas. No declama, no predica; pero como una férrea constante nótase la presencia - a veces apenas insinuada, a veces clara como un rayo de luz o límpida como la arista de un cristal- de su amor a las pobres gentes, de su fe en el porvenir, de su confianza en que el mundo se transformará para ser, al fin, equitativo y justo. La clave de su eficacia podría residir en la sorpresa que produce el descubrimiento (inevitable) de que esa evanescente y armoniosa poesía impresionista ha deslizado también un mensaje de lucha y esperanza. Juan L. Ortiz demuestra que puede lucharse sin estridencias y sin que la bondad que se defiende resulte contaminada y se pierda en el combate. Ha publicado, además del libro inicial, El alba sube (1937), El ángel inclinado (1938), La rama hacia el este (1940), El álamo y el viento (1947), El aire conmovido (1949), La mano infinita (1951), La brisa profunda (1954), El alma y las colinas (1956). (Giordano 1193)

La categoría de «poesía social» de Giordano se nutre, aplicada al «caso Ortiz», de ciertos rasgos - la no declamación, la no prédica, la falta de estridencia, la insinuación, la evanescencia, la complejidad- que señalan y precisan una posible tensión entre la decisión estética del poeta y la efectiva circulación de su obra en el contexto de la poesía social y militante argentina entre 1936 y 1946. 
La poesía social según Álvaro Yunque

Con la publicación de La literatura social en la Argentina de Álvaro Yunque la Editorial Claridad dio inicio, en el año 1941, a una nueva colección denominada Biblioteca de Escritores Argentinos. En la «Noticia sobre el autor», se aclara que dicha biblioteca se propone «reunir la mayoría de las obras que sobre las distintas manifestaciones del espíritu argentino publique la Editorial» (6). Cabe preguntarse qué perseguía Antonio Zamora, fundador y director de Claridad, hombre de izquierda que contaba por entonces con una extensa trayectoria como editor, al comenzar la serie precisamente con este libro de Yunque. Pero antes de esbozar una conjetura al respecto, es indispensable realizar una descripción del libro, que no gozó de reediciones, y también del contexto en el que apareció.

El título completo da una imagen cabal del plan de Álvaro Yunque: La literatura social en la Argentina. Historia de los movimientos literarios desde la emancipación nacional hasta nuestros días. El libro está dividido en nueve capítulos que se desarrollan a lo largo de 327 páginas. Resulta atractivo - tanto contemporánea como históricamente- porque brinda, por primera vez, una visión integral de la historia de la literatura argentina desde el punto de vista de la izquierda comunista. Organiza aquello que venía emergiendo en diversos ensayos en revistas como Rumbo, Columna, Conducta, Unidad o Nueva Gaceta, de plumas tan diferentes como la de Cayetano Córdova Iturburu, o los mencionados Amaro Villanueva y Héctor Pablo Agosti, entre otros.

Yunque realiza, a su vez, un interesante trabajo de escritura, alternando tonos, volviendo su prosa pedagógica, ensayística, narrativa, historicista según la necesidad del 
pasaje, algo que deviene en estilo. Este solo hecho coloca al libro en otro lugar que el de mero sumario de ideas. Los títulos de los capítulos y los materiales reunidos en el "Apéndice» son una buena muestra de esta mezcla de impronta partidaria y estilo propio. Se trata, en todo caso, de un compendio aumentado, polémico, audaz, de ninguna manera impersonal:

I.- El Arte intención y el Arte sonido

II.-Aparición de un pueblo y de una poesía

III.-El impulso de Mayo

IV.-La ilusión rivadaviana y la realidad

V.-Mayo y la Colonia

VI.-Renacimiento del arte civil

VII.-El Gauchismo

VIII.-Otra inquietud

IX.-El impulso proletario

\section{APENDICE}

Nota $I^{\circ}-$ Coplas de pobres y coplas de pobres contra ricos

Nota $1 I^{\circ}$ - Imposición de una determinada cultura y de su arte

Nota $1 \mathrm{II}^{\circ}$ - Leyendas aborígenes "dirigidas" por los misioneros católicos Nota IV - Boedo y Florida. (7)

A comienzo de la década de 1930 la Editorial Claridad — que había tenido su época dorada en la segunda parte de la década de 1920 acompañando a los escritores izquierdistas de Boedo- había quedado momentáneamente a la derecha de las expresiones más contundentes del comunismo combativo, cuyo caso emblemático lo representa la revista 
Contra, dirigida por Raúl González Tuñón. Las vueltas políticas, con el cambio de estrategia del PCA en 1935 y la consecuente profusión de producciones que tendían a matizar las diferencias con las otras fuerzas liberales, sumado al interés por la historia de la literatura argentina, habilitan el reencuentro entre la pluma de un intelectual comunista como Yunque y la editorial de izquierda más importante del país. La conjetura al respecto es que Zamora, director de Claridad, supo leer aquel momento del Partido, que gozaba de una extensa red de difusión - es decir, de potenciales lectores - interesados en una visión crítica de la cultura nacional. En la época en que florecía el revisionismo de tinte nacionalista, Yunque unía la agilidad de la prosa de estos nuevos actores con una trayectoria ensayística vinculada a las ideas en boga dentro del universo de izquierda. Tenía en su haber, además de su producción de narrativa, poesía y teatro, una biografía del escritor anarquista Rafael Barret y un libro de ensayos Ilamado Echeverría en 1837, contribución al estudio de la lucha de clases en la Argentina.

Yunque ve también su oportunidad y la sabe aprovechar. En el sentido en que no deja tema por tratar. Busca definir su terreno y no pierde oportunidad de zanjar deudas con una militancia atravesada anteriormente por la lucha de clases:

En un artículo de la polémica que escribí en el año 1935, contra una prédica seudo-social que, intentando distraer al proletariado argentino del leninismo en acción, le exponía como maestros a seguir a Echeverría —el del Dogmaa Alberdi y Sarmiento; decía yo que tales maestros, para argentinos que habían leído a Marx y Engels y meditado sobre la revolución rusa, nos resultaban matemáticos que, viniendo a enseñar las cuatro operaciones elementales, se encuentran con alumnos que saben cálculo infinitesimal. 
Ni Echeverría que no tuvo tiempo de salir de utopismo, ni Sarmiento y

Alberdi, constructores en la obra y en el pensamiento de la patria burguesa, ni Mitre que colaboró en una revuelta político-liberal entintada de artesanía, ni Mariano Fragueiro, economista con tendencia a un colectivismo estadual, todos sostenedores de la propiedad privada, se salen del jacobinismo.

Sarmiento tuvo para la Comuna del ' 71 frases tan condenatorias que nos permiten suponer que su actitud frente a ella hubiese sido la que tuvo el jacobino Robespierre ante los "excesos" de los herbertistas.

Pero hay algo más que sirve para ubicarlos ideológicamente. Es su miedo a las masas. (141)

No hay, en este libro de Yunque, un gramo de ingenuidad. A contramano de lo que podría pensarse como literatura doctrinaria, una etapa no cubre la otra. Más bien puede hablarse de un trabajo de presentificación de una experiencia militante que busca expresar un modo de entender la literatura argentina. Pero no la literatura argentina sin más, sino la literatura social en la Argentina. Esta es una distinción fundamental.

En libro mantiene, en ese sentido, una tensión entre historicidad y esencialismo, preguntándose qué define, en cada momento, el término «literatura social». Compone su trama en ese movimiento continuo de una forma a la otra, mostrando una versión de la historia literaria de la que es posible extraer una actitud ética, constitutiva de la literatura social. Por lo que la definición de la misma no se encuentra en un capítulo específico: es bordada por el desarrollo de la historia de la literatura argentina. Una síntesis, sin embargo, daría un resultado aproximado al que sigue: en el contexto de una sociedad dividida en razas, nacionalidades, culturas y clases sociales diferentes, es imposible la existencia de un 
arte universal; la literatura, por su parte, siempre toma partido, nunca es inocente; la literatura social es aquella que responde, en las horas excepcionales, de modo militante, incorporándose a la historia hasta fundirse con ella.

Cabe preguntarse, ciertamente, de qué historia de la literatura argentina se sirve Yunque para su trabajo. ¿Cuál es su fuente? ¿Dónde busca sus referencias? ¿O acaso fija nuevos avatares? La respuesta es que no le preocupa encontrar nuevos hechos, y su fuente tiene nombre propio: Ricardo Rojas. Yunque se interesa más por renovar la interpretación que por establecer nuevos sucesos. No es una elección que el libro solape, sino que representa una veta más del ánimo polémico que lo inspira:

Ricardo Rojas, a quien hablando de literatura argentina es imprescindible citar de continuo, dado que es el organizador pedagógico de ella y su investigador más meritorio, en una conferencia sobre Sarmiento, lo atacó por sus ataques a España. Y quien tiene razón aquí es Sarmiento, no Rojas. Estos son los inconvenientes de no estudiar la historia y de no hacer crítica literaria desde el ángulo de la lucha de clases. La hispanofilia sentimental de Rojas, le impide ver lo que vio Sarmiento, que juzgaba desde su ángulo burgués, en aquel instante de la hora del mundo, creador y revolucionario. (97)

El ángulo de la lucha de clases aplicado a la historia y a la crítica literaria define la originalidad del trabajo que Yunque realiza sobre la base del de Ricardo Rojas. La organización de los movimientos de la historia literaria argentina esbozada por este último, con el lugar central de la gauchesca, y, dentro de la gauchesca, del Martín Fierro como hito determinante, permanecen intactos tras su paso por el tamiz de Yunque. 
De esto que se apunta pueden extraerse al menos dos datos de interés. El primero remite al momento en que el Partido Comunista, a través de sus principales intelectuales, toma como suya, de manera más o menos crítica, la matriz liberal de la historia argentina. El libro de Yunque es un hito en este sentido ya que es el momento en que la intelectualidad comunista rubrica esa referencia general en un ámbito específico de la cultura, haciendo suya, críticamente, pero suya, la visión liberal de la historia de la literatura argentina. El segundo dato es menos elaborado pero no menos importante: la capacidad de Yunque para leer los efectivos aportes de Rojas sobre la historia de nuestra literatura y poder hacer uso de ellos.

Yunque se reserva, sin embargo, la posibilidad de realizar algunas operaciones importantes sobre el material. La fundamental es el recorte temporal que aparece declarado en el subtítulo del libro: «desde la emancipación nacional hasta nuestros días». La justificación del mismo, el desinterés por estudiar detenidamente todo lo que antecede, parte de una interpretación materialista de la historia o, para ser más precisos, de la lectura singular que el PCA realiza sobre las etapas económico-políticas en las que divide la historia nacional:

Sigamos con la cita de Marx y Engels, tan clarificadora. Dice: "La clase que detenta los medios de producción material, dispone por ello de los medios de producción espiritual bajo su yugo, las ideas de los que están privados de medios de producción espiritual." La burguesía argentina, al asaltar el poder que el derrotado feudalista debe cederle, impone en 1853 lo que impuso en 1810 cuando tuvo el poder en sus manos, por intermedio del inteligentísimo Rivadavia, sobre todo: Impone su arte, o sea su arte patriótico que, 
idealizándola, sirve de propaganda a la materialización de su sistema económico. (99)

La cita refiere los pasajes que, según la interpretación comunista de entonces, hubo entre el sistema feudal y el sistema burgués: con la revolución de 1810 irrumpe la burguesía, que va a ceder su poder al caer Bernardino Rivadavia en 1927, el feudalismo se impone nuevamente con Juan Manuel de Rosas para, en 1853, caer definitivamente ante la burguesía liberal. Según esta lectura, el gobierno de Rosas, aún extinto el vínculo colonial con la corona española, representa un retorno al sistema político feudal que imperaba con anterioridad a 1810. Ambos momentos del feudalismo, el colonial y el rosista, tendrán un dispar impacto, según Yunque, sobre la literatura social en la argentina. Mientras desestima y ubica por fuera de su libro la etapa colonial del período feudal, se ve intensamente atraído por la literatura escrita bajo el signo de Rosas:

Héctor Pedro Blomberg, que cultiva el pintoresquismo rosista, publicó una antiantología titulada "Cancionero Federal", con versos de los "poetas" que loaran las hazañas de Don Juan Manuel y lloraran la muerte de Doña Encarnación Ezcurra o piropearan la "gracia y blandura de corazón" de Manuelita... La lectura de este libro malo resulta francamente aleccionadora. Vicente López, por ejemplo, autor del Himno, transformado en un burócrata poltrón, el único nombre meritorio con que cuenta la literatura tiranófila, se halla en tal decadencia literaria que hasta parece haberse olvidado de contar las sílabas. [...] Pero si el trabajo que se tomó Blomberg, recogiendo en periódicos de la época toda la bajeza versificada que en su libro nos brinda, merece nuestro aplauso, es, precisamente, porque en su libro no pudo 
recoger una sola poesía, un solo poeta "sincero y auténtico". El argumento que pretendió presentarnos en favor de la tiranía es, precisamente, la más rotunda negación de ella. (65-66)

A esta argumentación puede sumarse su descripción y reconocimiento de la figura de Pedro de Angelis, intelectual al servicio de la causa de Rosas. Yunque despliega, nuevamente, un tipo de escritura vivaz:

Angelis era, empero, laborioso, erudito, bibliófilo, perspicaz, arisco para la polémica, la literatura que el momento requería. Sus críticas del Dogma echeverriano, en 1846, cuando éste lo publicó en libro, lo prueban. Dúctil, sabe buscar las grietas y meterse por allí, a morder con sus dientecillos filosos y agudos. Echeverría sale a la lid, y le pega duramente; Angelis, hábil polemista, pincha y corta. Sería curioso recopilar cuánto escribió este cortesano, este espumoso y risueño meridional, pintoresco personaje de la corte de Palermo, en defensa del amo. (68)

Por supuesto que Yunque prestará atención, y en ello se le irán unas cuantas páginas, a la literatura escrita por los exiliados del rosismo. En eso sigue casi literalmente a Rojas, quien troca el término tiranía por proscripción para nombrar y definir la etapa. Pero en estos fragmentos que hemos transcripto es donde Yunque se vuelve original, en el momento que alterna el diálogo con una reciente antología de poesía pro rosista - a la que lee de manera crítica como «antiantología» - con la descripción del políglota Angelis. Como si buscara dar una voz al rosismo. Complejiza el panorama al sugerir compilar (en vez de aquello de Blomberg, podría reponerse) todo lo que el «espumoso y risueño meridional» escribió sobre 
Rosas. Pretende, en todo caso, un enemigo de una talla más digna que los poetas de Blomberg para esta etapa en que vuelve a asomar - siempre siguiendo su interpretaciónel sistema feudal pero ya en un contexto de nación independiente.

Si el comienzo de la literatura social nacional se da a partir de la gesta de Mayo de 1810, Yunque buscará, un tanto erráticamente, signos latentes de esta rebeldía en la etapa anterior de la colonia. Así es como cita una carta al Rey escrita por funcionarios de Asunción en 1594 donde ya se enuncia un amor por las cosas nuevas de aquí. Y también las coplas populares que expresan la rebelión del pobre contra el rico. Los define como signos latentes. Pero la colonia será, según sus propias palabras, «una larga siesta». Por otra parte, el estudio de las leyendas aborígenes, que podrían establecer una novedad y un tono propio, americano, son desechadas con el argumento de que han sido, tal como nos llegan, dirigidas por los misioneros católicos. El tercer capítulo del apéndice está dedicado a documentar esta afirmación: «En la región del litoral particularmente- afirma一, allí donde actuaron los más inteligentes de los misioneros católicos, los jesuitas, los que mejor supieron aprovechar la abundante agua poética de las tradiciones a fin de dirigirla hacia su molino, las leyendas han sido transformadas para hacerlas servir a la religión» (315). Las leyendas, así presentadas, no trastocan para Yunque el orden político colonial, sino que lo alimentan y prolongan.

Es, como se decía, el impulso anti feudal de la Revolución de Mayo el que inaugura el ciclo de la literatura social en Argentina. Un proceso que afecta y es afectado por la literatura:

La Revolución de Mayo ha sido estudiada como fenómeno político, como fenómeno militar, como fenómeno religioso y, últimamente, por las actuales 
generaciones, como fenómeno económico, y según algunos, como resultado de la lucha de clases en la cual puede incluirse la acción que el imperialismo inglés, mediante su diplomacia, ejerció persistentemente para ponerla a su servicio. Pero, como toda verdadera revolución, la argentina, trastocadora del régimen feudal, es también un fenómeno literario. (27)

El panorama que Yunque traza sobre la historia de la literatura social de Argentina parte de Mayo y tiene un importante componente evolucionista, de etapas que marcan un progreso que no culmina en el presente sino que se proyecta hacia el futuro. Futuro que no es otro que el de la revolución comunista. Es la expresión, en el campo de los estudios literarios, del imaginario comunista que concebía, en continuidad, el triunfo de las fuerzas burguesas, la generación de un capitalismo nacional de cuyo desarrollo derivaría la efectiva existencia de un proletariado capaz de tomar, llegado el momento, iniciativas revolucionarias. En este libro de Yunque, esto adquiere una verdadera especificidad, ya que cada etapa queda vinculada a una variante del género épico:

Nace nuestra literatura cuando se producen las invasiones inglesas, hecho social que se continúa en la gesta de Mayo: nuestra literatura es épicopatriótica. Irrumpe la guerra entre federales y unitarios: nuestra literatura es épico-política. Llega la organización nacional: nuestra literatura es épico-civil. Aparece la clase proletaria, consecuencia del industrialismo; la lucha de clases oculta en los anteriores fenómenos históricos, aunque presente siempre, se torna visible para todos. Y es entonces cuando todos no coinciden en la justificación del arte literario. Parte de nuestra literatura se hace "social", otra sigue siendo patriótica o política, o civil. (11-12) 
El señalamiento sobre la lucha de clases, oculta al mismo tiempo que siempre presente en todos los fenómenos de la historia nacional, permite visualizar, una vez más, los corrimientos interpretativos que diferencian a Yunque de Ricardo Rojas. Tal es el caso de la gauchesca. En la «Introducción» al tomo I de la Historia de la literatura argentina, Rojas escribe: «Bajo sus toscas apariencias, la obra de tales poetas [Hilario Ascasubi, Estanislao del Campo, José Hernández] encierran los gérmenes originales de una fuerte y sana literatura nacional». La gauchesca representa, para Rojas, el alma genuinamente argentina, los ideales de un arte nacional, signado «por el verismo de la descripción, por el regionalismo del vocabulario, la vida, las costumbres, el espíritu de nuestros gauchos, la emoción de las pampas y selvas nativas» (54). En ese contexto, el Martín Fierro representa para Argentina lo que la Chanson de Roland a Francia y el Cantar del Mío Cid a España, es decir, el gran poema épico nacional. Yunque acepta el lugar destacado del Martín Fierro dentro de la gauchesca, incluso su perspectiva épica. Pero el ideal que lo motiva, según él, no tiene que ver con una esencia de la nacionalidad sino con la puesta en escena, y toma de partido, frente un conflicto de clase:

Martín Fierro es literatura social, de protesta y propaganda, de lucha y polémica, tendenciosa; pero su tendencia fluye de su acción, no de un programa explícitamente formulado. Le basta ser realista para ser un bravío documento histórico, un recio embate contra la injusticia social, una amarga requisitoria punitiva del humano egoísmo. Hernández sentía el dolor del prójimo, del gaucho que él tan bien conocía, clase desheredada y sacrificada de la sociedad argentina, y porque es un sentidor es un profundo revolucionario. (133) 
Está lectura en clave del Martín Fierro se propagará por el universo comunista hasta llegar a ser un lugar común del mismo. Crítica y pico, de Amaro Villanueva, libro contemporáneo a este de Yunque, transita el mismo derrotero, buscando en las huellas de lo escrito la certeza de un saber sobre las cosas del gaucho que habilite entender la escritura de Hernández como una forma de realismo redentor, con marcas clasistas.

Yunque reconoce, al mismo tiempo, que el Martín Fierro es, en 1941, en gran medida un hecho estético. Traza otra serie que la de Rojas: lo pone en tanda con La llíada de Homero, los poemas de Dante y Milton, El Quijote de Cervantes, los dramas de Schiller, los poemas de los antiesclavistas estadounidenses Greenleaf Whittier y Russell Lowell y los antiesclavistas brasileros Tobías Barreto y Antonio Castro Alves, las Briznas de Hierbas de Walt Whitman y el «Canto a Roosevelt» de Rubén Darío, para afirmar que «los conflictos por cuyas ideologías estas obras de arte bregaban, ya han desaparecido o se han atenuado, y de ellas ahora se percibe sólo lo que tienen de humano eterno, no de circunstancial político» (145).

Yunque se ocupa de ese resto, de algo que podríamos denominar como resultado artístico. Emprende la tarea de visualizar las obras desde el presente, a la luz de una sensibilidad militante pero también de una sensibilidad lectora, definible, está última, en términos estéticos. Hablará de las contradicciones del quehacer de un escritor social: para que la pasión creadora pueda acrisolarse y tamizarse largamente y así generar una autentica obra de arte se requiere de tiempo. Y tiempo es lo que precisamente falta a quien es, además de escritor, actor de la historia en los momentos álgidos. Muchas veces lo escrito, dice, cae más en el terreno de la acción que en el del arte. «Lo prueban cincuenta de los cincuenta y dos tomos de la "Obra Completa" de Sarmiento" (42). Yunque consigna el dato pero no juzga. Lejos está de ver con malos ojos esta producción que es fruto de la hora: «Se 
podría argüir -escribe- que poco de aquel intencionado arte sobrevive, que muy poco resiste a un juicio severo o a la comparación de las grandes obras. Pero aquel arte cumplió su misión de exaltar ánimos, y su siembra dio frutos, si efímeros como mazorcas de maíz, útiles. No hicieron esto quienes, apartados de su hora excepcional, sólo balbucearon el arte de los sonidos» (56).

A medida que avanza el libro, la trama y la misma concepción de poesía social se complejiza. Yunque tiene certezas respecto de los inicios de la literatura social en argentina pero no así de su presente en 1941. De allí la dedicatoria del libro: «A los jóvenes escritores que historiaran lo que nosotros presentimos». La figura de un eslabón que une, en fuga hacia el futuro, el presentimiento y la historia, haciendo una posta de una generación a otra.

Sobre la dedicatoria es posible volver una vez terminado el libro, sobre todo después de haber transitado sus páginas finales, de tono ensayístico más que historiográfico, donde abundan los conceptos pero escasean los nombres y los libros. La línea de tiempo que él mismo traza lo posiciona en el campo inexplorado del presente literario argentino de finales de la década de 1930. Yunque presiente, tienta, pero sabe que deja su tarea inconclusa.

Buena parte de los análisis del último capítulo del libro, «El impulso proletario», están dedicados a desbrozar el terreno de la literatura comunista. Esta representa, desde su perspectiva, el final de la cadena evolutiva de las literaturas de izquierda, el grado máximo de conciencia, compromiso y comprensión de la realidad. En 1943, dos años después de la aparición de La literatura social en la Argentina, Yunque publica — como ya se ha anticipado - la antología Poetas sociales de la Argentina (1810 - 1943). El recorte temporal que traza es similar al que se viene analizando. Comienza con la Revolución de Mayo y marca una línea evolutiva hasta la actualidad. En el primer tomo, reúne los poemas alrededor de las siguientes categorías: 
1. Poetas anónimos y gauchescos (Bartolomé Hidalgo, Estanislao del Campo, José Hernández);

2. Poetas idealistas (Ricardo Gutiérrez, Almafuerte, Diego Fernández Espiro);

3. Poetas anarquistas (Alberto Ghiraldo, José de Maturana, Edmundo Montagne, Evaristo Coalova Arias, Federico Gutierrez, Domingo Fontanarrosa, Rodolfo González Pacheco, Fernando del Intento, Salvadora Medina Onrubia);

4. Poetas socialistas (Manuel Ugarte, Mario Bravo, Ernesto Mario Barreda, Ernesto Castany);

5. Poetas de diversa inquietud (Evaristo Carriego, Ricardo Rojas, Benjamín Taborga, Pero Herreros, Baldomero Fernández Moreno, Antonio Gil);

6. Poetas de Boedo (Roberto Mariani, Elías Castelnuovo, Leónidas Barletta, Gustavo Riccio, Aristóbulo Etchegaray, Salas Subirat, Juan Guijarro, Delgado Fito, Juan Prieto, Margarita del Campo, Pedro Godoy, Álvaro Yunque, Julia García Games, Juan Filloy, Nicolas Olivari, Rodolfo Tallón, Feliz Molina Tellez, Ferrari Amores, Santiago Ganduglia, Simón Contreras, Guillermo Etchebehere, Alberto Natiello, José Rodríguez Itoiz).

Mientras que en el segundo tomo aparecen:

1. Poetas del descontento campesino (Juan Draghi Lucero, José Pedroni, Bernardo Canal Faijoo, Luis Gudiño Kramer, Amaro Villanueva, Gaspar Benavento, Marcelino Román, Horacio Rava, Blanca Iruzun, José Román Luna, Emma Barrandeguy, Gerardo Pisarello, Carlos Carlino, Domingo Zerpa, Avalos 
Noguera, Juan Enrique Acuña, Manuel Castilla, José Fernández Molina,

Cristófaro Juarez, Antonio de Latorre, Julio Díaz Villalba, Julio Cézar Luzzatto y Gaspar Medrano Rosso)

2. Poetas judíos (Carlos Grunberg, Cesar Tiempo, Lázaro Llacho)

3. Poetas comunistas (Cayetáno Córdova Iturburu, Raúl González Tuñón, José Portogalo, Lila Guerrero, Horacio Raúl Klapenbach, Juan Ortiz, Eloisa Ferraría Acosta, Alfredo Varela, Clara Rafael, Feliz Marthoz).

La antología culmina como se ve con los «Poetas comunistas», a los cuales presenta del siguiente modo:

El año 1918, el Partido Socialista se escinde. Quedan en el viejo partido los social-demócratas. En el nuevo que toma el nombre de Partido Socialista Internacional, se alistan los jóvenes revolucionarios. La social-democracia se inclina por la ruptura de relaciones con las potencias centrales en guerra con el Imperio Británico, Francia y Estados Unidos, también se muestra recelosa de la revolución soviética - a la que pronto, siguiendo las huellas del reformismo europeo enfrentará, francamente enemiga. El Partido Socialista Internacional, en cambio, se opone a la ruptura de relaciones y se hace el vocero sudamericano de la U.R.S.S. Más adelante, este partido toma el nombre de comunista. Hacia él polarizan las fuerzas proletarias y los jóvenes intelectuales; a él se agregan escritores ya maduros que abandonan el anarquismo, la social- democracia o el liberalismo indeciso donde actuaron en sus años iniciales. 
Indudablemente, la poesía social de la Argentina, está representada hoy por los poetas del comunismo. Los demás: liberales civiles, social-demócratas o anarquistas, callan, escépticos y, sobreviviéndose al entusiasmo y la fe que los hizo épicos, se han refugiado en la elegía, dubitativos y lacrimosos. (137)

La poesía comunista implica para Yunque una responsabilidad. Sobre el final de La literatura social en Argentina, hace un esfuerzo por determinar qué es y qué no es literatura social. En ese momento aflora, con mayor peso que nunca, aquello que de continuo parecía soslayarse o encontrar justificaciones, que es la cuestión de la calidad literaria. No es literatura social, comunista, dirá, aquella que difícilmente pueda ser comprendida o elegida por los trabajadores. Y da un ejemplo:

Sol de martillo, luna de acero y máuser.

Bronce y oxígeno en el ímpetu.

Fuego y juventud firme de altura.

¡Todos - hierro duro al pulmón- en marcha!

Esta composición, Ilamada "Juventud comunista en marcha", es la primera del libro y le da pauta. Todo es así: gongórico en la expresión y arrítmico. Estos "poemas proletarios", pues, no pueden ser populares nunca. El pueblo es más artista de lo que suponen los retóricos de vanguardia — vanguardia literaria-. Esta prosa, mal colocada tipográficamente, se puede aceptar como párrafos - poco eficaces - de discurso o de proclama; pero no es poesía, y nunca puede ser poesía proletaria. Sin claridad y sin ritmo no entra al alma del pueblo. Y este debiera ser el propósito fundamental de un "poeta proletario". Porque si no es así, ¿ para qué escribir "en proletario"? (288) 
El gesto de discutir en términos estéticos la cuestión de la eficacia hay que colocarlo del lado de las virtudes del libro, ya que desnuda los valores que sustentan el trabajo crítico de Yunque. La literatura social tiene su culminación en la producida por los comunistas, pero, he aquí el señalamiento que complejiza esta etapa, no toda la literatura producida por los comunistas es literatura social. Esa diferencia vuelve atractivo su trabajo, pues no se detiene en la antesala de los problemas que una obra como La literatura social en la Argentina necesariamente importa, sino que ataca, define, refleja e intenta dar solución a los mismos. El resultado es, como se decía, una versión personal de esa elaboración colectiva realizada por el comunismo criollo a partir de la segunda mitad de la década de 1930 sobre la historia argentina, y, en particular, sobre la historia de su literatura. Lectura realizada con la finalidad de generar, al interior de las filas, pero también como propaganda, una génesis que les permitiera posicionarse a ellos mismos en la culminación de la historia social de la nación, en el vértice de todo advenimiento revolucionario.

\section{La poesía social según Héctor P. Agosti}

Si se dispone de compás y papel, y se trazan dos círculos de manera tal que una parte de uno - más o menos un octavo, por caso- se superponga al otro, irremediablemente se notará la aparición de una tercera figura determinada por el área de superposición de ambos. Al primer círculo se lo llamará «Literatura Pura», al segundo, "Literatura Militante». Al óvalo que entre ellos se forma, simplemente se lo sombreará y se dirá que ese perímetro sin nombre es el espacio que han abierto, de uno y otro lado, intelectuales y escritores interesados en anular las fronteras. Se puede, también, sacar una flecha del óvalo sombreado y dejar señalado que es allí, y no en otro lado, donde debe colocarse la figura 
intelectual de Héctor P. Agosti. Esos son sus límites, por haber dicho sí a la literatura pura y sí también a la literatura militante, por haber desdeñado con atendibles razones las diferencias entre ambas. Ese es el territorio donde se mueve. Sus límites no solamente provienen de los moldes que le imponía la militancia en el Partido Comunista Argentino, sino del trayecto que se forma entre estos y otros moldes, los presentes en su pensamiento, marcado por la supervivencia de una concepción romántica de la literatura.

Pero no es una afición a la matemática lo que conduce a hablar de círculos, de espacios superpuestos, sino la propia historia intelectual de Agosti, la genealogía en la que él mismo, con razón, se inscribe. De Esteban Echeverría a José Ingenieros, paso uno; de José Ingenieros (liberal) a José Ingenieros (socialista ingenuo y pro-soviético), paso dos; de José Ingenieros a su heredero, Aníbal Ponce, paso tres; de Aníbal Ponce (liberal) a Aníbal Ponce (libre pensador comunista), paso cuatro; de Aníbal Ponce a su heredero, Héctor Agosti, paso cinco; de Héctor Agosti (joven militante comunista) a Héctor Agosti (principal cuadro intelectual del PCA durante la década infame y el peronismo). Esa herencia explica el rasgo de doble pertenencia.

¿Qué lee Agosti en Echeverría, Ingenieros y Ponce sino la disponibilidad sincera, entera, de esos intelectuales hacia sus causas, por sesgadas o erradas que se quieran? La tradición liberal, cara a los comunistas, le brinda otros tantos ejemplos del carácter utilitario que ha tenido el arte en la historia de Argentina. Limitación, dificultad autoimpuesta, error conceptual, sobre todo en sus peores acepciones, ese rasgo suele incluirse en un axioma que define un vasto territorio: no habría literatura de izquierda sin idea de utilidad. Pero Agosti hará suyo también a Domingo Faustino Sarmiento, y entonces ese axioma no sólo resulta anacrónico, sino que está errado: la idea de utilidad no es inherente a la literatura de izquierda, sino a toda literatura militante. Sea del bando que sea. Agosti esgrime, autorizado 
por el PCA en su etapa de Frentes Populares, a la plana mayor de la intelectualidad antirrosista del siglo XIX como ejemplo de integridad civil e intelectual. Lo hace mientras sufre en carne propia, al igual que algunos de aquellos, el exilio montevideano (Defensa del realismo, de 1945, se edita de hecho en Montevideo), la persecución y la cárcel del régimen (Uriburu-Justo-Ortiz-Castillo), del golpe de 1943, del peronismo, y también de la Revolución Libertadora.

«Que no haya paz —escribió Raúl González Tuñón en una nota para la revista Claridad de abril de 1937- hasta que las puertas de la cárcel se abran y pueda salir a la luz del día el querido camarada, a decir otra vez su verdad, a hacernos oír nuevamente su mensaje. Agosti, nuestra bandera. Saludemos en él al intelectual más perseguido por la clase dirigente, descompuesta, entregadora del país. Y también al más querido por la clase laboriosa, a la que ha ofrecido su destino» (González Tuñón, Agosti). Un año más tarde, el suicidio de Leopoldo Lugones conmovió al mundo intelectual argentino. La última de las muchas pieles del poeta había sido la del lobo, pregonando «la hora de la espada» desde Lima, en 1924, en ocasión del centenario de la batalla de Ayacucho. Fiel a la idea, su hijo, llamado también Leopoldo Lugones, había sido el jefe de la jefe de la división Orden Político, responsable de la Sección Especial de la policía creada por José Félix Uriburu para perseguir, encarcelar y torturar a los anarquistas, comunistas y radicales. Sobre este personaje, apodado Polito, y su padre, ha escrito Carlos Mastronardi en una carta a Cesar Tiempo fechada el 24 de febrero de 1932:

De Polito Lugones todo es dable esperar. Ya en su 1ra juventud quiso ser militar, pero luego transfirió esa veleidad cuartelera a su señor papá. El eruptivo talante de Lugones no se prolonga en el hijo, que solo heredó 
sombras de ademanes-espirituales-paternos: la noción rígida de jerarquía, la vocación despótica y esa teatralidad de vigilante que se advierte en Don Leopoldo cuando emboca el clarín de la épica y cuando nos asegura que el valor es un "producto" netamente argentino. Claro está que la conducta literaria de este hombre (política aparte) es algo ejemplar en nuestro ambiente, donde la literatura "es" un descanso, una vocación de la medicina, la abogacía o la "quiniela". Pero ello no impide que haya engendrado a Polito, cuyo intacto equipaje mucho lamento no haya sido consignado al fondo del mar.

De lo cual se infiere que la resonancia del apellido Lugones en aquel febrero de 1938 en que se produjo el suicidio de Leopoldo padre, no podía tener notas más oscuras. Y sin embargo, he aquí la parte sustancial del responso de Agosti, escrito y publicado en 1938, y luego incorporado a su libro La milicia literaria (1969): «Entre la poesía evangélica y ripiosa de Almafuerte, por ejemplo, y la poesía verdadera de Lugones, yo opto por esta última. Lugones es el artista; uno de los pocos - si no el único- que hemos tenido en nuestras letras. Es el poeta "puro", el gran poeta "puro"» (34). Es llamativo que un mártir comunista alabe de este modo al Lugones de 1938. Por eso hay que pensar en los círculos, sobre todo el que encierra a la «Literatura Pura». Agosti le ha dado entidad en su frase, y ha colocado allí dentro a Lugones, el gran artista, el poeta puro, demarcando en ese mismo movimiento los límites de su reino. Lo que parece una gran alabanza, no lo es tanto. Lugones no es el gran poeta. Es el gran poeta puro. Ese adjetivo cifra buena parte de la herencia intelectual de Agosti: el poeta, el poeta sin más, es el que mora en la intemperie del óvalo gris que se forma en la superposición entre la literatura pura y la literatura militante. 
Agosti daba a la literatura pura el estatuto de arte. En cambio, pensaba a la literatura militante, en sus manifestaciones más burdas, como una forma pre-poética, pre-literaria. Pero exponía allí, en el análisis de la literatura militante, una salvedad ineludible, la de colocar en la balanza de las cotizaciones los valores literarios del escritor junto a sus valores civiles. Insistía en la necesidad de contrapesar ese valor civil, que podía o no expresarse literariamente. Esta fuga de lo estético es la expresión más acendrada de su pertenencia también - al círculo de la literatura militante. Del mismo modo en que rescata al «poeta puro» Lugones, rescatará las más extremas incursiones de González Tuñón a la «poesía militante». Del mismo modo significa una sola cosa: críticamente.

La vida de Agosti puede leerse como la historia del intelectual orgánicamente ligado a un partido. $\mathrm{O}$, para usar sus palabras, como la del intelectual militante. Lo que resulta llamativo es el consenso que parece existir acerca del valor negativo que ha jugado el PCA en su vida. A las notas sobre su labor intelectual como director de revistas culturales de primera línea, como autor de libros importantes, o sobre sus viajes y sus contactos americanos, europeos, rusos, a ese lugar que obtiene por haber sido el introductor de Antonio Gramsci en América del Sur se le opone, como una sombra, su indeclinable filiación stalinista. Cabe reponer, entonces, que no hay dos Agosti: no hay Agosti por fuera del PCA. No hay revistas, ni libros, ni Gramsci introducido en esa época por fuera del PCA. Lo más absurdo, pero también lo más sutil de su obra está ligado al Partido Comunista. Escribió Agosti en una conferencia de 1942 (1969):

Alguna vez tendrá que hablarse entre nosotros del heroísmo de la crítica. Alguna vez deberá decirse que la crítica militante es en la Argentina el peor de los oficios. Y más adelante: Entre nosotros la crítica sólo se concibe de dos maneras: o como brulote despiadado al adversario de cenáculo, o como 
elogio desmedido al compañero que al día siguiente habrá de retribuir con iguales alabanzas. Fuera de estas dos "categorías”, ¿qué otra crítica existe? (La milicia literaria 13).

Esta conciencia de estar fuera de lugar, de estar ejerciendo el peor de los oficios, aparece por destellos en su obra: «Falta la crítica sistemática [...] El comodín del gusto personal facilita, claro está, la política de los clanes cerrados y la sumisión a los personajes que manejan la bolsa literaria» (La milicia literaria 13) Néstor Kohan (2004) da a entender que Agosti hizo un pacto con Victorio Codovilla y Rodolfo Ghioldi, los líderes del Partido, obteniendo libertad plena de especulación teórica a cambio de no meterse con la línea política del partido. Este hecho le habría permitido conformar, al interior del PCA, «un espacio de reflexión autónoma que se condensa en las revistas culturales Expresión y Cuadernos de Cultura» (Kohan). Es una hipótesis que brinda una solución posible para esa prolongada convivencia que comenzó cuando Agosti tenía sólo 16 años de edad, en 1926, y perduró hasta el día su muerte, en 1984. Descontado el hecho de que se resiente la imagen de Agosti como un intelectual crítico capaz de ofrecer una respuesta sincera en cualquier esfera del orden público y partidario, la hipótesis de Kohan saca a la luz uno de los artilugios posibles a los que puede recurrir el intelectual orgánico (perteneciente a un partido) para obtener libertad de acción en su campo específico. Sin embargo, aplicada a la historia particular de Agosti, hay muchos cabos que quedan sueltos.

En principio, ceñidos a la etapa de esta investigación, la autonomía intelectual, así como la creación de un espacio propio para un desarrollo no dogmático de las ideas, era una necesidad compartida. Lo que era una condición indeclinable para el crecimiento personal e 
intelectual de la figura de Agosti, comportaba, para el PCA, un interés táctico como desprendimiento de su cambio de rumbo, de esa búsqueda de consensos amplios necesaria para la conformación del mentado Frente Popular. ¿Qué necesidad tenía Agosti de pedir lo que ya le estaban dando? Por otro lado, Agosti consustanciaba las medidas del Partido y sus propuestas estéticas de manera indisociable. De manera tal que se hace difícil pensar en un juego irónico, en un acto sacrificial de su voluntad crítica en pos de cumplir un pacto con el stalinismo.

Un buen ejemplo de esto es la publicación del poema «22 de junio», de Juan L. Ortiz, en Nueva Gaceta, la revista de la Asociación de Intelectuales, Artistas, Periodistas y Escritores que Agosti dirigió en sus dos etapas (1941-1943 y 1949). El viraje de la política del PC, y en consecuencia del PCA, que supuso el pacto de Rusia con la Alemania nazi de agosto de 1939 - conocido como Ribbentrop-Mólotov - fue uno de los más cuestionados a lo largo de la historia del partido. Quienes antes acusaban una guerra antifascista y reclamaban el cese de la neutralidad argentina, comenzaron a hablar de "guerra entre imperialismos», relativizando el componente ideológico del Eje, y apoyando, por consiguiente, la neutralidad Argentina. El 22 de junio de 1941, la invasión nazi al territorio soviético obligó a un nuevo y bochornoso cambio de rumbo. El poema de Juan L. Ortiz, publicado menos de un año después pero todavía en plena contienda, no podía ser más elocuente al respecto de la amenaza que representaba el fascismo para el mundo intelectual; pero lo era, y aquí está el punto, sin resignar el carácter sugerente, altamente elaborado de su escritura. El contenido ideológico del poema, su basamento, bien podría resumirse en estas líneas escritas por Agosti en 1941 (1969): 
El escritor argentino está preocupado por la guerra; entiende que el destino de la civilización se está jugando en los campos de batalla; comprende que el nazismo es la amenaza más peligrosa para los valores esenciales y permanentes de la cultura; sabe que, aunque situado a miles de kilómetros de las trincheras, la inmensa contienda ya lo está golpeando y amenaza con castigarlo cada vez más rudamente. (La milicia literaria 25)

Que esos versos hayan sido elegidos por Álvaro Yunque para la sección de «Poetas comunistas», dentro de Los poetas sociales, es la afirmación más contundente del carácter partidario del poema. Prueba de su alta calidad estética y de su clave simbolista, es que no haya, entre las cientos de notas que acompañan la Obra Completa de Juan L. Ortiz que compiló Sergio Delgado, ni una sola mención al Partido Comunista Argentino, sin que ello haya impedido que sea considerado como uno de los poetas fundamentales del siglo XX en nuestra literatura, con nutridas proyecciones entre los lectores del siglo XXI. La eficacia estética de la poesía de Ortiz es independiente de su vinculación con el Partido Comunista Argentino. Su obra se sitúa en esa zona que se dibujó para el propio Agosti: pertenece a los dos círculos al mismo tiempo. Por lo tanto, la decisión de Agosti de publicar «22 de junio» ayuda a comprender, puntualmente si se quiere, que no existía un distanciamiento - ni un acatamiento irónico - de las líneas políticas del Partido, sino que Agosti aprovechaba las circunstancias reales de la coyuntura para experimentar nuevos modos de entender la relación entre política y poesía, entre arte y militancia, frutos de su ardua tarea intelectual.

Agosti no hizo lo que hizo a pesar del Partido Comunista Argentino, sino con el Partido Comunista Argentino. Era el grado operativo del asunto, podría especularse, lo que le atraía de la militancia partidaria. Un campo real para la experiencia utópica: juntar el ojo puro con 
el ojo militante, modelar otros paisajes de intenciones para el arte. En los cincuenta y ocho años que duró su experimento, se sucedieron un buen número de logros y otros tantos fracasos.

Defensa de realismo, su libro de 1945, es su obra se central del período. Opera como una antología de ensayos con múltiples propósitos. Cada capítulo del libro corresponde a una conferencia distinta, ante un público distinto, en diferentes momentos históricos (del 1939 a 1945) y con diferentes intenciones teóricas y militantes. Lo primero que cabe preguntarse es: ¿por qué defensa? Es un título fuerte que lejos de plantear el problema estético en sí, crea, por su propia dinámica, un otro, un adversario. Pero lo que sucede en realidad, por la diversidad de esas múltiples conferencias que conforman Defensa del realismo, es que no existe un único adversario, ni una sola intención. El momento central, el que corresponde a la conferencia "Defensa de realismo», aúna las preocupaciones que se dispersan en todo el libro, y luego en toda la obra de Agosti, cubriendo los flancos del debate a la vez que presentando el nudo propositivo de su desarrollo. Agosti presenta al realismo como lo no creado, como una síntesis que aguarda en el futuro, una zona a la que debe tenderse. Pretende, de este modo, defender una idea que aún no tiene realización, la utopía de un nuevo realismo: «Se trata nada menos que de prever el futuro, nada menos que de "soñar pronósticos realistas"» (64)

Pero ¿̇ante quién es que realiza esta defensa? El libro permite vislumbrar dos grandes frentes. El primero tiene que ver, fundamentalmente, con el debate en torno a la novela que vuelve a tomar fuerza en la década de 1940. Parece que la presencia de José Ortega y Gasset, quien llega nuevamente a nuestro país a mediados de 1939, funcionó como un disparador del asunto. Algo tardíamente, se comenzó a discutir en torno a su libro de 1925, Ideas sobre la novela. Nada podía inventarse ya, había propuesto entonces Ortega, todas las 
posibilidades de la acción novelesca habían sido exploradas y utilizadas. La acción debía ser desterrada, reemplazada por la contemplación, por la morosidad, cuyo representación extrema sería la obra de Marcel Proust.

A la ya clásica intervención de Jorge Luis Borges en el prólogo de La invención de Morel de Adolfo Bioy Casares, de 1940, para defender, por supuesto, la invención y la trama, hay que agregar lo dicho por Roger Callois en Sociología de la novela de 1942, libro editado por Sur, donde se propone, en principio, a la novela como un género triunfante, en crecimiento, y también algunas de las aguafuertes de Arlt en El mundo, publicadas entre 1940 y 1942. Tres de las cuatro conferencias que Agosti reúne en 1945 en el capítulo 3 de Defensa del realismo, "Los problemas de la novela», fueron pronunciadas entre 1940 y 1941, y representan el aporte personal y partidario a ese encendido debate de principio de 1940.

El segundo de los frentes abiertos por el libro es lo que podría denominarse como el «frente interno». En términos específicos, el combate al realismo mecanicista:

Las leyes del desarrollo histórico son leyes objetivas que la voluntad de los hombres no podrá alterar; pero el conocimiento de esas leyes objetivas permite utilizarlas para acelerar el proceso social, que no es una pasiva sucesión -gris sobre gris- de transformaciones económicas y cambios ideológicos que las sigan como la sombra al cuerpo. Por eso representa una ingenuidad afirmar, por ejemplo, que "no habrá buenas novelas mientras no se haga la reforma agraria", porque ese vulgar sociologismo implica, evidentemente, abolir el papel de la ideología y suponer que el intelectual no es un elaborador de la cultura, y por lo tanto un posible elaborador de la 
cultura de avanzada, sino un mero papel carbónico que registra los acontecimientos de la sociedad una vez que estos acontecimientos ya se han instalado en la naturaleza económica de la sociedad. (Para una política de la cultura 19)

Si bien la cita es posterior al libro, permite figurar el «frente interno» mejor que esa atomizada recurrencia al marxismo clásico en el terreno de la literatura que abunda en Defensa del realismo. Las buenas maneras para con los camaradas alineados con el «realismo socialista», que veían novelas realistas sólo donde había una revolución realizada -léase Unión Soviética- así lo requerían.

Estos dos frentes, el de la discusión sobre la novela y el combate al mecanicismo, se prestan como puntos de fuga en la conformación de su perspectiva del «nuevo realismo» de Agosti. En un trabajo denominado «El realismo y sus destiempos en la literatura argentina», María Teresa Gramuglio (2002) coloca en un lugar interesante el salto que propuso Agosti dentro del pensamiento dogmático comunista: «Con todo, fue el mérito de Agosti admitir por fin que no es posible exigir, en nombre del realismo, la "uniformidad de los medios expresivos", ya que una misma estética común puede admitir diversidad de poéticas y soluciones formales. A partir de esta comprobación, desmanteló la oposición entre realismo y arte abstracto para postular, con un giro casi hegeliano, la "superación hereditaria" del arte abstracto en el nuevo realismo (dinámico)» (35). El magma de las contradicciones que planteaba la idea de herencia puede resumirse en esta frase de Agosti: «No podría negarse la calidad estética de Proust, algunos de cuyos procedimientos de introspección analítica deberán rescatarse en la nueva novelística. Pero ésa es la literatura de la decadencia social, sin trama, sin nervio, sin sangre, sin acción» (Defensa del realismo 54). 
Esta última frase revela no sólo el carácter hereditario de su propuesta que señalaba Gramuglio -tomar lo mejor de unos y otros, no abandonar la experimentación, recoger los frutos de lo hecho-, sino que es índice del problema coyuntural que precipita su aventura crítica hacia un «nuevo realismo». Se trataba, para redactarlo distinto, de negar a Proust en contra de Ortega y Gasset, pero por motivos radicalmente distintos a los de Borges. Por ser literatura de la decadencia social, podría decirse. Un análisis que Borges desdeñaría. Y a su vez, en contra de la idea dogmática de la novela realista dentro de la tradición crítica marxista — que era, y quizás siga siendo, la decimonónica en la versión de Georg Luckacsrescatar procedimientos de lo que vino después, de Proust, de las vanguardias, para fundirlos en un nuevo «realismo dinámico».

Dos libros que escribe Agosti por esa misma época, Emilio Zola (1941) y Literatura Francesa (1944) atestiguan el conocimiento profundo que el intelectual comunista tenía de ese período de la novela realista francesa. No mucho más, tampoco, porque se trata de libros de difusión para colecciones de cultura general, cuya escritura le fue encargada por la Editorial Atlántida durante su exilio montevideano. Pero el dato no es menor, porque son pocos los restos que permanecen de esas indagaciones en su proposición de un «realismo dinámico» dentro de Defensa del realismo. Con lo que debemos suponer la propuesta de Agosti como un intento superador de la del propio Luckacs, y no como una continuidad acrítica. Al respecto de esto último Laura Juárez (2008) brinda un dato interesante en una nota al pie de su artículo «Arlt y la polémica sobre la novela»: al menos desde el año 1936 los ensayos sobre realismo del húngaro circulaban en las revistas de izquierda argentinas.

En una conferencia fechada en Rosario en septiembre de 1940, titulada «Los problemas de la novela», Agosti (1945) intenta resumir esta relación: 
El nuevo realismo constituye un doble proceso de asimilación y superación del anterior. Sólo en ese sentido es posible hablar de retorno. Si dicho retorno pudiera esquematizarse en algunas reglas $-\mathrm{y}$ nada más difícil que encerrar en reglas a la novela- deberíamos señalar primeramente que el nuevo realismo es crítico - fundamentalmente crítico-, pero afirmativo, en el sentido de percibir el objeto y mostrar en él la tendencia al movimiento (dinamismo) y la tendencia a la transformación del mundo (activismo transformador). (56)

¿Dónde encontrar semejante novelista capaz de superar a los grandes maestros del XIX, aislando con mano experta los mejores procedimientos de las aventuras vanguardistas para fundirlos en una nueva aleación? ¿Dónde hallar a ese escritor de corazón romántico y pensamiento dialéctico?

El carácter propositivo de las fórmulas de Agosti desnuda la ausencia de ejemplos concretos que mostrar. Recurrir a la literatura soviética para zanjar una disputa criolla no era una alternativa. Hubiese sido, entre otras cosas, dar el brazo a torcer a sus camaradas del «frente interno». El único novelista que tiene su propio apartado en Defensa del realismo es Enrique Amorim. Pero el tono de Agosti es poco entusiasta. Aunque estima los logros, no parece ser su ejemplo:

De las dos partes que componen El caballo y su sombra, es evidentemente la segunda la mejor lograda. Vuelve a encontrarse ahí el dinamismo propio de la narración novelesca, que es característica especialísima de Amorim. En el libro hay hallazgos psicológicos, detalles finamente captados, paisajes dibujados con un equilibrado sentido de los matices. Pero hay también, en 
algunos momentos, especialmente en la primera parte, ciertos descuidos elementales que conspiran contra la economía de la composición. (80)

Es indudable, y ha sido recalcado, que un concepto de uso extendido en la crítica literaria y artística en general como lo es el de realismo, presenta muchas variantes teóricas. Alcanza un simple repaso de los grandes maestros occidentales que han atendido el asunto, desde Erich Auerbach a Georg Luckacs, desde Bertolt Brecht a Roland Barthes, para notar cómo el concepto varía no sólo de autor en autor — de modo que es difícil hablar de continuidadessino dentro de los mismos autores según las épocas, incluso dentro de un mismo libro, como el caso de Mimesis, adquiriendo modulaciones diferentes frente a cada nuevo caso. No sería incorrecto afirmar la filiación luckasiana del realismo de Héctor Agosti. Pero tampoco sería correcto, porque la mera idea de que sea propio del realismo dialogar con las experiencias estéticas de las vanguardias es la negación de Luckacs. El concepto de realismo adquiere en Agosti su propia rugosidad, sus propios campos de uso e, incluso, su propia vaguedad conceptual.

En un capítulo ignorado de Defensa de realismo, se esconde una de las proyecciones críticas más interesantes que hay sobre la relación entre poesía y política en todo el período. Se trata del capítulo IV del libro, titulado "La poesía y nuestro tiempo», que se divide a su vez en los siguientes apartados: «Una nueva generación de poetas», «La poesía de Juan L. Ortiz», «La poesía de Raúl González Tuñón».

Si llama la atención que haya un capítulo dedicado a la poesía en un libro llamado Defensa del realismo, escrito y editado en una época signada, como se ha dicho, por el problema de la novela, más extraña aún resulta la presencia de un apartado con un trabajo sobre Juan L. Ortiz, fechado en 1939. ¿Existe algo más alejado que la propuesta de Juan L. 
de una idea, cualquiera sea, de realismo? ¿Qué hace este poeta que conjuga de manera personalísima la herencia modernista de Darío con aquella otra del simbolismo francés, en un libro que se propone defender el realismo, escrito por un intelectual de gran peso dentro del PCA? ¿Por qué se favorece a esa poesía que ostenta una notoria ausencia de obreros, de fábricas, de ciudades, de peones rurales, de frigoríficos, de saladeros? Y en el colmo de la extrañeza -lo que rebela la potencia de la propuesta - ¿Qué hace apareciendo por delante de la de Raúl González Tuñón, poeta social por antonomasia?

El resultado que arroja la mirada de Agosti sobre el panorama de la poesía argentina de finales de 1930 y principios de 1940, reflejado en Defensa del realismo, descarta la idea de la existencia de una nueva generación de poetas, remarca sin afectaciones el fracaso parcial del sentido estético del Tuñón más combativo, en términos del realismo romántico que propone el poeta en su prólogo a La rosa blindada, alegando que «no siempre está cumplido en su obra», y, finalmente, coloca bajo el signo de Juan L. Ortiz la posibilidad de una nueva realidad en materia de poesía:

La poesía de Ortiz atiende igualmente a esta proyección mítica. Y la cumple redondeando su destino optimista, depositando poderosa fe en el porvenir. No puede desoírse semejante mensaje. Por encima de sus vibraciones temporales y de las discrepancias de temperamento - e incluso de predilección formal- debemos admirar en Ortiz la sinceridad de su enunciado poético, la profundidad ideológica de sus poemas, la sobriedad de sus imágenes y la alta calidad de su lenguaje. Estamos frente a un verdadero poeta. No cabe otra calificación más definidora. (113) 
No hay mayor halago, proviniendo de un crítico comunista, que el señalamiento de profundidad ideológica. Y en este caso, aparece junto a otro, central en el sistema de Agosti, como lo es la alta calidad del lenguaje. Se retorna de este modo a los círculos de la «literatura pura» y «la literatura militante». En este caso, a esa zona en la que ambas conviven. Ortiz ya no es, como Lugones, el gran poeta puro, sino «un verdadero poeta» a secas.

Lo que no le sucede a Agosti en la novela, eso de encontrar la realización ejemplar de su concepción de realismo, le sucede en la poesía. Pues el llamado, el vocativo, ese «debemos admirar más allá de las predilecciones formales» apunta definitivamente al «frente interno» del Partido. Entablar la discusión en ese terreno hubiese significado ceder a la idea del realismo como un estilo o una escuela. Agosti no está hablando de sus gustos personales, todo lo contrario. Él es un lector capaz de disfrutar de la forma poética incluso cuando se encuentra aislada del componente ideológico, como en el caso de Lugones. Es un llamado, como se decía, que parece propugnar una idea superadora del concepto de realismo literario al interior del propio PCA.

Sería erróneo pretender, por otra parte, que la poesía reviste para Agosti menor interés que la novela. «La poesía - escribió en 1959- es el lenguaje que canta, y el canto es siempre un instrumento de comunicación entre los hombres, porque nadie concebiría al cantor sin auditorios, al cantor sin ecos, al cantor despoblado de resonancias» (La milicia literaria 31) 


\section{El Martín Fierro de Amaro Villanueva}

Pocos mensajes tuvieron una gravitación tan significativa dentro de la intelectualidad de izquierda vinculada al Partido Comunista Argentino durante las décadas de 1930 y 1940, como el que pronunció Aníbal Ponce en su conferencia en la Facultad de Ciencias Económicas de Buenos Aires del 30 de junio de 1930, titulada «Los deberes de la inteligencia». Lo que Ponce expresaba allí, replicaría en forma de proclama, de artículo, de poema, de cuento, de ensayo, de libro, a lo largo de los años siguientes. Sería una fuente a la que los intelectuales acudirían para obtener los justificativos necesarios para orientar aquellas labores determinadas, ya sin reservas, por un doble interés erudito y militante. Ortiz, como se ha visto, no fue una excepción.

La represalia que Ponce debió soportar en 1936 a causa de su desempeño como presidente de la AIAPE, que involucró, en su grado máximo, la intervención directa de diputados y senadores alineados con Agustín P. Justo, quienes lograron despojarlo de sus cátedras pese a la aguerrida defensa que de él realizó Lisandro de la Torre; el escarnio público al que fue sometido y gracias al cual debió abandonar el país, otorgó a aquel discurso suyo de 1930 un sentido profético. El accidente y su prematura muerte en el exilio mexicano en 1938, terminaron de situar no sólo sus palabras, sino también su figura, como un emblema del intelectual militante. Juan Antonio Salceda, Álvaro Yunque y Héctor P. Agosti, entre otros, coincidirían con los años en el deseo, y por qué no en el deber, de escribir y publicar una biografía suya.

Ponce representa para ellos la figura del intelectual hecho a sí mismo, serio, aplicado, generoso y creativo, cuyos logros no le son externos, es decir, otorgados por el mero prestigio de las instituciones y los títulos, sino por el fruto de su labor y talento, cuya última medida la determina el grado de contribución, de aporte, que manifiesten con la historia y 
el desarrollo futuro del país. Un intelectual que, finalmente, y sólo como resultado de su reflexión crítica, se encamina hacia la lucha revolucionaria.

La clave que brinda Ponce seguiría gravitando todavía en 1945, año en que se publicó, en la ciudad de Santa Fe, Crítica y pico (Plana de Hernández) de Amaro Villanueva. Su amigo y colega periodístico, Luis Gudiño Kramer, a cargo de la Colección Nuevo Mundo de Ediciones Colmegna, fue quien lo presentó antes los lectores. Se transcribe a continuación parte de lo que se lee en las solapas del libro:

Amaro Villanueva, escritor de ceñida y fervorosa consagración a las letras, nació en Gualeguay, Entre Ríos, al comienzo de este siglo, y desde muy joven, después de recibirse de profesor secundario, actuó en el periodismo y ejercito una cátedra o magisterio libre y particular (porque no era rentado) aunque general por la difusión y alcance de sus propósitos...

No es ditirambo arrancado a la amistad el de estos acertos [sic], sino necesaria y justa proclamación debida a un hombre sencillo en sus actos, aunque orgulloso de su saber honrado y de su plenitud de conciencia; no jactancioso de ello pero sí arrogante; laborioso y descuidado de su propio reclame; amante del pueblo de su patria y al mismo tiempo del hombre en cualquiera de sus formas o apariencias.

Amaro Villanueva es un escritor del interior argentino que conoce y aprecia su país, ama su pasado y demuestra atenta preocupación por el porvenir de su pueblo.

Gudiño Kramer continúa en la misma tesitura hasta agotar la caja de la segunda solapa. Pero basta con lo expuesto para precisar algunos señalamientos iniciales. Las palabras que ha 
elegido usar, la forma peculiar, bastante extraordinaria en que ha decidido presentar a un autor de ensayos sobre el Martín Fierro ante los lectores; en definitiva, la perspectiva que ha asumido, se torna difícil de comprender si no se repone debidamente, como hemos hecho, la clave de Ponce. Desde la «cátedra libre» al «saber honrado», desde «el descuido de su propio reclame» a la «atenta preocupación por el porvenir de su pueblo», hay un eje que templa una moral intelectual. Para emprender una tarea crítica de tamaña dimensión, parece decir Gudiño Kramer, poco importa el título que se tenga, pues lo que esta exige, sobre todo, es entereza, coraje intelectual y una aguda inteligencia.

Pero la clave de Ponce señala, en este caso, algo más que una moral intelectual. De manera más específica, revela el grupo de pertenencia de Villanueva. Los rasgos que Gudiño Kramer concede al autor de Crítica y pico son análogos a aquellos que reclamaban como ejemplares los intelectuales del Partido Comunista Argentino. De lo cual se infiere, puestos en la plena contemporaneidad de los sucesos, que una presentación semejante apuntaba a dejar asentado ese lugar. A explicitarlo, entiéndase, sin ser abiertamente explícito. El vínculo con Ponce suponía, más que nunca, una clave.

Poco elocuentes para la posteridad, pero fácilmente discernibles en la época, tal es el sesgo que adquieren, analizados a la distancia, los discursos militantes comunistas de aquellos años, sobre todo tras la Revolución de Junio en 1943. En el sentido de que a una mayor una mayor presión policial, no sobrevino, como cabe esperar, un aumento paralelo de la violencia contestataria sino lo contrario, una dilatada estrategia para la difusión de ideas democráticas de alto alcance nacional. Se intenta explicitar que la estrategia de Frentes Populares, que suplantó en 1935 a la anterior de Lucha de Clases, tuvo un impacto sensacional en la forma en que el comunismo criollo evadió, en el terreno de la cultura, la censura de aquellos años. 
Transitando límites difusos en los que el gesto revolucionario se desvanecía tras el velo democrático, lograron, por prepotencia de militancia y trabajo, una productividad extraordinaria y perdurable. La AIAPE, sin ir más lejos, antes de ser clausurada en 1943, contaba en su haber, como ya se ha señalado en el capítulo anterior, con La rama hacia el este de Juan L. Ortiz, Un horizonte de cemento de Bernardo Kordon, y De la colonia a la revolución de Rodolfo Puiggrós, por nombrar sólo tres títulos importantes, diversos en género y factura.

No debe deducirse de esto que el gobierno de la Revolución fuese inocente frente a las estrategias comunistas. Basta revisar el inciso tercero del documento base de fundación del GOU (Grupo de Oficiales Unidos), quienes habían motorizado el golpe de estado, para caer en la cuenta de que por el contrario, era precisamente este peculiar cariz de la estrategia el que había encendido las alarmas, sembrando paranoia entre las filas: «La inseguridad política puede llevar, en un plazo más o menos corto, a una de las siguientes situaciones: [...] 3) Triunfo del "Frente Popular" disfrazado como Unión Democrática, que busque inmediatamente o en forma inmediata (sic), la revolución comunista de España o Chile» (Torre 55-56).

Para seguir con el ejemplo, la clausura de la AIAPE — agrupación en la que también actuaba Villanueva - es uno de los tantos hitos que marcaron un antes y un después en el proceso de un tipo de sociabilidad y en el grado de persecución que se instaló sobre las redes intelectuales de la izquierda a partir de 1943. A lo cual puede sumarse un dato coyuntural interesante para el tema particular de la gauchesca «militante»: la supervivencia y actualización de los controles sobre el contenido radiofónico, donde esgrimiendo el cuidado de la pureza del lenguaje, el gobierno censuraba «todo lo que revistiera un carácter netamente popular, ya sea en la música, el teatro, el recitado, etc.» (Horvath 136) . El nuevo 
montaje legal se daba por medio de una norma de la Dirección de Correos y Telégrafos, pero la censura operaba ya desde 1938, es decir, desde el gobierno de Roberto M. Ortiz, Lo cual termina por aproximar el cuadro en que se enmarca la aparición del libro de Villanueva. Hablar del Martín Fierro en 1945 no era, de por sí, un hecho incómodo ni contestatario. Lo que era incómodo y contestatario era la impronta que, aún antes de leer la primera página, dejaba adivinar Crítica y Pico.

Si bien el plan del libro es bastante anterior a su salida, este parece llegar, en términos polémicos, en un momento justo. Y Villanueva lo sabe. En la advertencia, titulada «Algunas palabras», puede leerse:

La unidad del presente volumen ha de verse en un interés vocacional, consecuente en sus capítulos, por conocer mejor las cosas nuestras, nombradas así, en términos de generalización, por el tributo parcial con que todas ellas concurren a la manifestación de una literatura, ya pertenezcan al orden material o a la órbita del espíritu, ya se hundan en el pasado, comporten el presente o transiten hacia el porvenir. A través de los temas aquí desarrollados se advertirá, asimismo, de un modo u otro, la indeclinable militancia intelectual con que algunos de los más eminentes obreros de nuestras letras dieron respuesta, en su tiempo, a la siempre renovada cuestión sobre la función específica del escritor y del artista en la estructuración de la sociedad, participando responsablemente en la orientación de la nuestra, para que fuese lo que la esperanza del hombre dio en llamar al continente americano: la concepción de un nuevo mundo; esperanza que hoy se restaura con sentido ecuménico por el 
esfuerzo doloroso y progresista de los pueblos que están aniquilando al despotismo. (9)

Más allá de reponer el contexto de la Segunda Guerra Mundial, interpretándolo como una lucha de los pueblos progresistas contra el despotismo, lo que se desprende como polémico de estos párrafos inaugurales es el sentido utilitario del abordaje de los textos: no es por mero regodeo crítico, sino para advertir la indeclinable militancia intelectual de sus autores con su tiempo y con la patria que se los estudia. Hay un uso en la medida en que existe una proyección: si la discusión sobre función del escritor en la estructuración de la sociedad se ve, como afirma Villanueva, continuamente renovada y actualizada, el conocimiento y estudio de los casos emblemáticos del pasado nacional es esencial para actuar frente a los dilemas de 1945.

Resulta curioso observar que los atributos de intelectual militante que Gudiño Kramer encuentra en Villanueva, vuelve este último a encontrarlos, palabras más, palabras menos, en los autores que estudia: principalmente en José Hernández, pero también en Juan María Gutiérrez y en Bartolomé Hidalgo, a quienes dedica sendos capítulos del libro. Es decir, el modo en que el editor presenta a su autor, se asemeja al modo en el autor presenta a sus escritores. Esta contigüidad entre las diferentes instancias del libro produce un resultado sugestivo: los atributos de Ponce, conducidos por el hilo sutil de esta serie de herencias, se vuelven ubicuos. Su figura irradia, en adelante, tanto a la de Amaro Villanueva como a la de José Hernández, a la Gutiérrez y a la del mismo Hidalgo.

En su aspecto formal Crítica y pico se divide en cuatro capítulos. Los dos iníciales, «Plana de Hernández» y «Preludios del Martín Fierro», están dedicados íntegramente al autor del poema. El primero discute con estudios anteriores cuestiones puntuales de 
fraseología o terminológicas del poema; el segundo aborda una interpretación del sentido general de los preludios. El tercero, «Don Juan María, Poeta» está dedicado a Juan María Gutiérrez y el cuarto, "El ingenioso Hidalgo», a Bartolomé Hidalgo; aunque en estos, menos incidentalmente de lo que pueda suponerse, vuelven a aparecer cuestiones relacionadas directamente con el Martín Fierro. Por último, presenta un suplemento documental vinculado al capítulo 2, que transcribe los juicios críticos que a la salida del Fausto de Estanislao del Campo escribieran José Mármol, Juan Carlos Gómez, Ricardo Gutiérrez y Carlos Guido y Spano.

«Hablo como me sale del pico» explica Villanueva, para dar cuenta del segundo término del título del libro (12). Pero la lectura no acaba nunca por mostrar la escritura desbocada, despareja, azarosa, que una declaración así haría suponer; sino más bien lo contrario: una prosa atenta, contenida, precisa.

Hay, sin embargo, al menos dos notas que distinguen y dan entidad al «pico». La primera es la presencia de una forma solapada del humor; la segunda, que se verá a continuación, tiene que ver con la utilización ad hoc de la fuente de la experiencia. La imagen es la de quien transita, pero no se detiene, en la pericia libresca, dando entidad a otros signos, poniéndolos en pie de igualdad llegado el caso.

Critica y pico pretende probar que Hernández fue un escritor y un intelectual militante de su tiempo. Para ello, Villanueva decide refrendar el conocimiento que el poeta tenía de las cosas del gaucho. Escoge una expresión criolla que ha sido trabajada detenidamente por otros estudiosos del Martín Fierro, en cuyos veredictos podría entreverse una virtual incompetencia del poeta, y la trabaja en un apartado del capítulo inicial que la lleva por título: «Bolear el anca». 
El concienzudo seguimiento de fuentes, entre las que figuran los predecibles Eleusterio Tiscornia, Santiago y Leopoldo Lugones, Ricardo Guiraldes, y los no tan predecibles Francisco Javier Muñiz — con un tratado sobre el ñandú - y Vicente Rossi —con sus «Folletos Lenguaraces»-, de los cuales Villanueva va extrayendo y consignando pareceres, se lleva casi trece páginas del libro. Pero no será sino al toparse con «Don Teófilo Chamorro, natural del Corrientes, hombre de edad con pátina, amigo de lecturas, notable conocedor de la añeja vida campestre y de las flores del habla gaucha» (53), que llega el autor a dar con la verdadera fuente que buscaba, aquella capaz de confirmarle el correcto uso dado a la expresión por Hernández. Pero la cita a Teófilo, el correntino, no se presenta sino como una ratificación de algo sabido: «Que es necesario ser toro para bolear el anca, es verdad recibida del conocimiento campesino. Lo aprendimos cuando muchachos, en nuestras andanzas por la campaña de Entre Ríos» (53).

Esta suerte de indagaciones y, sobre todo, esta clase de resoluciones - que remiten al "pico», del Crítica y pico-, atienden también, puede especularse, al interés de Villanueva por presentar a Hernández como un «obrero» del intelecto, plenamente consciente de sus herramientas de trabajo, al tiempo que se presenta a sí mismo en una notoria relación de continuidad.

Como corolario de la anécdota, para no perder registro del territorio mencionado, cabe indicar que la reivindicación de tinte regional no es ajena al libro. En la propia contratapa, puede el lector encontrar lo siguiente:

Editorial Colmegna de Santa Fe se propone contribuir al mejor conocimiento de la Argentina mediante la difusión de los principales hechos del pasado y del presente vivo y en constante progreso de integración, y de los hombres 
que dieron fisonomía propia a esta región de la República integrada por Santa Fe, Entre Ríos y Corrientes, provincias que de manera principal han contribuido a formar la nacionalidad y que han dado un temple particular al hombre litoralense, tal vez el más representativo de esta nueva nación y al mismo tiempo, el más próximo a este sueño de civilización y de progreso que cada vez identifica más a nuestro hombre con el europeo y el americano culto. (Crítica y pico)

La correspondencia que Amaro Villanueva mantuvo con Cesar Tiempo desde mediados de 1937 - conservada en el Archivo «Cesar Tiempo» de la Biblioteca Nacional - brinda una oportunidad estupenda para conocer el proceso de creación de este libro, no exento de anécdotas. Tiempo dirigía entonces la revista Columna, de considerable prestigio entre la intelectualidad de izquierda, donde publicó, desde el mismo número inicial los estudios que Villanueva realizara sobre el Martín Fierro. Es la misma revista, cabe recordar, donde Ortiz publicó su cuento Martín.

El 21 de octubre de 1937, desde Paraná, Villanueva despachó, junto a un nuevo artículo, una carta reveladora:

Querido Tiempo: Ahí va ese otro engendro "filológico", camino de la comprensión de nuestro "Martín Fierro", con todas las confusiones que le acarrea esta mala máquina de escribir [...] No es difícil que este artículo suscite alguna sonrisa. Pero lo importante será mantener esa sonrisa cuando se quiera rectificar lo que ahí se dice. En fin: usted verá. Verá también, por este artículo, que mi presunto libro no puede alimentar ninguna presunción sobre premios nacionales. Eso se deja para los 
correntinos, es decir, aquellos que siguen la corriente... (Alberdi diría: para los que se conforman con el presente, como los ladrones). Y ahí está lo modestamente heroico de mi "Denuncia de Martín Fierro", como ha de llamarse el libro para que sea testigo también de este tiempo y no solamente de los pasados. Por otra parte, comprendo que no podré terminarlo para un tiempo adecuado para su edición este año.

Ni para aquel año, ni para los siete siguientes estaría listo el libro. Pero es interesante advertir que su impronta, su función, se concibe desde el vamos como un acto de irrenunciable y declarada militancia intelectual.

Para llevarlo a cabo Villanueva erige, paso tras paso, artículo tras artículo, una sólida tarea de investigador literario. Cuando dice «lo importante será mantener esa sonrisa cuando se quiera rectificar lo que ahí se dice», lo que está exponiendo no es un extravagante orgullo de ensayista, sino el as en la manga de su estrategia como polemista: mostrarse, antes que nada, competente en el terreno objetivo y generosamente transitado de los comentarios literarios, para recién desde allí pegar el salto militante. Recorre ese camino, el que parte del rigor a prueba de toda duda, y no el inverso, para evitar, precisamente, que lo soslayen y no se lo tome en serio. Es el modo estratégico que escoge para fortalecer su mensaje.

Llegado al colmo de la escrupulosidad, toda su atención se concentrará obsesivamente alrededor de un acento. En la misma carta le relata a Cesar Tiempo:

Para seguir con Fierro me hace falta una precisión sobre un acento de la carta de Hernández a don Zoilo Miguens, pero no le pido esa manito porque habría que ir a la Biblioteca Nacional... y allí lo puede cascar el de la flor del durazno 
[se refiere a Hugo Wast]. Le escribiré a Mastronardi, quien —supongodispone de más tiempo libre que usted y hace mucho que le debo respuestas. Los amigos son para eso. ¡Parece mentira, che, lo que puede decirnos un simple acento! De "imaginaran" a "imaginarán". Tiscornia pone la palabra sin acento en su edición del Martín Fierro. Y me parece que así tiene que ser. Pero en todas las ediciones vulgares que he logrado obtener y que son posteriores aparece con acento. Me confiaría en Tiscornia si no le hubiera pescado numerosos errores. $Y$ entonces hay que ir a la fuente. $O$ irse al carajo.

Recién una vez que tuvo el dato, Villanueva se dispuso a intervenir en la polémica abierta por Leopoldo Lugones acerca de un virtual desconocimiento del campo literario por parte de Hernández. Y fue incluso más lejos, al plantear que no sólo lo conocía al dedillo, sino que lo intervino críticamente en esa carta, que mencionaba al Fausto de Estanislao del Campo, pero también, elípticamente, las composiciones realizadas sobre el motivo de las fiestas del 25 de mayo, ambientadas en la ciudad, donde el gaucho se encuentra desnaturalizado. Sobre el asunto del acento, promediando el Capítulo 2, se lee:

Pero lo más sugerente del transcripto párrafo de la carta a Miguens, porque confirma la presunción de que Hernández debió intervenir en las discusiones de ese momento, trabadas en torno al candente problema literario de la época, está en su parte final: “... y Ud. no desconoce que el asunto es más difícil de los que muchos se lo imaginaran". En las malas ediciones del poema, este último verbo anda futurizado, con acento: imaginarán. Pero don José Hernández lo escribió sin acento, en pretérito imperfecto de subjuntivo, con 
todo el embuchado que este modo verbal suele alojar en la frase. Y, por lo que se lee, fueron muchos los que subestimaron, literariamente sin duda, las premisas, argumentos y razones de Hernández referentes a la dignificación del género. ¿Quiénes fueron esos mucho? Tampoco lo sabemos, ni lo sabremos ya. Bástenos pues, saber que fueron muchos. (85)

Este modo estratégico de Villanueva, la claridad con que resuelve la cadena lógica que conduce al dato filológico hasta su destino militante, termina por arrojar un saldo favorable en uno y otro ámbito, posicionándolo como precursor de una renovación sobre la mirada que se extendía sobre el Martín Fierro argentina hasta aquellos años.

Para los comunistas, marcó un hito inicial de adopción del poema junto al clasista y explosivo capítulo que Álvaro Yunque dedicó a Hernández en La literatura social en la Argentina, publicado, como se ha indicado, en 1941. Villanueva no cita ese libro ni una vez en esta primera edición, pero si lo hará, de manera insistente, en las reediciones posteriores, tal como lo atestigua la versión de Crítica y pico que se recoge en el primer tomo de sus Obras Completas, publicado por la Universidad Nacional de Entre Ríos en 2010.

Este trabajo de Villanueva, que posicionan a Hernández en la cima de los precursores de la poesía social argentina, fue adoptado por Ortiz. En el momento de publicarse Crítica y Pico ambos vivían en Paraná. Cabe recordar las palabras de Ortiz en El Litoral, invitado junto a Villanueva por Gudiño Kramer, en ocasión del 25 de Mayo de 1942:

«La inteligencia argentina tiene así ahora una doble responsabilidad militante y creadora: la del resguardo y la ampliación de las conquistas logradas con tanta sangre y sacrificios y la de promover, con la acción, el pensamiento y la sensibilidad unidos, el nacimiento de nuestra alma hecho una sola cosa con 
nuestro paisaje y nuestras gentes. Sólo así seremos dignos de Moreno y de Echeverría, de Gutiérrez y de Hernández» (Obra Completa 1055)

El caso de Hernández permite ilustrar el modo colectivo en que se construyó la historia de la poesía social argentina dentro de la sociabilidad comunista. Hecho que incluyó un considerable intercambio entre los escritores e intelectuales del interior y sus colegas de Buenos Aires. El litoral argentino puede considerarse y estudiarse, en este sentido, no solo como un verdadero foco de producción poética (cuestión que se aborda en el apartado que sigue), sino también ensayística y crítica.

A modo de curiosidad, ya que escapa por unos pocos años del período estudiado, cabe consignar la existencia de poemas de Ortiz donde se produce un correlato casi directo con estos discursos: con la línea de Mayo que aparece en Agosti y Yunque, con el rol del intelectual militante de Ponce y la inclusión, en esa órbita, del José Hernández de Villanueva. Es lo que puede leerse en este pasaje del poema «Y el cielo será más que nunca Azul y Blanco», que se incluye en El junco y la corriente, de 1957:

Oh, la rosa asimismo viva de las sangres diversas, a los vientos del mundo siempre abierta, en el armonioso campamento, pero con un perfume "hondo" de "cielitos" desde el Mayo natal, un fluido de "Dogma" abierto sobre la visión de Moreno, con la inspiración de Echeverría, de Gutiérrez y de Hernández, para recrear su destino profundo en medio de las corrientes fecundas, la línea militante de su alma en el camino de su mensaje... Oh, la rosa argentina, al fin, en la estrella de la síntesis asumido ya Mayo hasta la comunión real. (Obra Completa 631-632) 
Villanueva, como se ha dicho, ocupa sin dudas un lugar importante en el contexto de la producción teórica y de historia literaria propia del comunismo criollo. En estos estudios sobre el Martín Fierro se conjuga la clave de literatura social con efectivos aportes de investigación literaria: un pie en la saga de estudios tradicionalistas sobre el Martín Fierro, el otro en la novedosa intención de incorporar al Martín Fierro al universo de la literatura comunista. Su caso interesa, además de por su peso propio, por la cercanía geográfica y la amistad que mantiene con Ortiz. Villanueva, a diferencia de Yunque y Agosti, construye su aporte desde Paraná.

\section{Poetas sociales del litoral argentino}

Atentos al año en que Villanueva comienza a publicar sus Versos gauchipolíticos, 1931, cabría indicar que fue la poesía su práctica inicial, que luego se desenvuelve de manera militante hacia el campo de la historia de la poesía argentina. Como sea, existe un efectivo vaso comunicante entre sus estudios y esos poemas publicados originalmente en El Diario y luego en Entre Ríos, ambos periódicos de Paraná, a comienzos de la década de 1930.

La Obra Completa de Villanueva editada por la UNER bajo la dirección, una vez más, de Sergio Delgado, aporta libros y papeles inhallables, y una serie de ensayos críticos indispensables para ubicar su producción. Entre ellos, la propia «Introducción» de Delgado; el trabajo de Claudia Rosa ya citado en el primer capítulo de esta tesis, «Entre Gualeguay y Paraná»; y el ensayo «El problema de la expresión nacional. Elementos para una primera lectura en conjunto de la poesía de Amaro Villanueva», de Daniel García Helder.

Este último traza, en un solo párrafo, una sugestiva semblanza de Villanueva: 
Lo cierto es que nació en el mismo pueblo que Juan L. Ortiz (1896) y Carlos Mastronardi (1900), la avanzada simbolista de la escuela entrerriana; pero a diferencia de éste no hizo bohemia juvenil en Buenos Aires, y a diferencia de aquél se fue del pueblo rápido, una vez recibido de maestro normal y bachiller. Tras unos años en "la populosa ciudad de Rosario", donde estudió medicina y se empleó en Vialidad Nacional, se radicó definitivamente en Paraná, ejerciendo la docencia, el periodismo y formando parte activa del grupo intelectual aglutinado alrededor de Carlos María Onetti (1894), cuya actuación en la capital mesopotámica significó “algo así como el advenimiento de una época", según Villanueva en una ojeada retrospectiva de 1943, "la época de la conciencia poética, de la severa disciplina crítica: la época del aula magistral, en el mejor sentido, y de la peña literaria pública y divulgadora, animada y simpática, chispeante y fraternal”. Esa época poco menos que dorada en la que Villanueva se dio a conocer como escritor, poeta, periodista, investigador artesanal, bohemio y agente cultural coincide con la década del 30 y tiene su epicentro en Paraná. (23)

Que la amplia actividad desarrollada por Villanueva haya tenido su centro en Paraná no impidió el contacto y el reconocimiento de su labor a nivel nacional. Las revistas porteñas en las que publicaba sus ensayos, y lo que se desprende de la correspondencia sostenida con Cesar Tiempo son buenas pruebas de ello. Pero nada rubrica tanto su pertenencia al universo de la poesía social como su inclusión en la antología Poetas sociales de la argentina, de Álvaro Yunque, en 1943. Su ingreso no se da como «Poeta comunista», como en el caso de Juan L. Ortiz, sino en una categoría diferente: «Poetas del descontento 
campesino». Yunque ubica allí, a su vez, a Emma Barrandeguy, al paranaense Marcelino Román y a los santafesinos Luis Gudiño Kramer y José Pedroni. La selección no contempla sólo el litoral argentino. Podemos encontrar también al santiagueño Bernardo Canal Feijóo y al salteño Manuel J. Castilla, entre otros veintitrés poetas que dan cuerpo a esa categoría, precedida por la siguiente introducción:

En 1896, la Unión Industrial Argentina presentó un petitorio al gobierno para que "destierre a los perturbadores del orden social". En 1902 se promulgó la "Ley de residencia" a fin de expulsar a los obreros exigentes. Los ideólogos burgueses no podían concebir a un argentino siendo anarquista o socialista. Tener ideas era ser extranjero. Algo semejante ocurrió después de la revolución soviética con los hombres de provincia: tener ideas para ellos, era ser comunista, o sea, porteño. Y sin embargo, la pauperización, el analfabetismo, la miseria orgánica; se asientan en el campo más terriblemente que en la capital abierta al Atlántico y a Europa. El descontento campesino tiene más poderosas razones de ser que el descontento obrero de las ciudades. Y la penetración ideológica, si más lenta por la mayor ignorancia, es efectiva también en los campos y colonias. Que ya ha comenzado a cobrar voz en el arte lo dicen fuertes narraciones, duros dramas y los claros poemas aquí recogidos. El campo corre ahora el riesgo de perder su "arcádica pureza", su "candidez eglógica", según la expresión de los ideólogos caros a los latifundistas. En realidad, lo que está perdiendo es su idiotismo - a estar [sic] con la definición del preciso Carlos Marx. Tal vez haya aquí quien eche de menos el nombre de Carlos Ortiz. Nacido en Chivilcoy, 
donde en 1910 fuera asesinado por las hordas del caudillismo local. Pero en sus "Poemas de las mieses", se limita a exaltar el campo y las labores campesinas, en un ambiente idealizado. No cabe, pues, en la categoría de poeta social. Es un romántico entintado de filosofía pránica. (7)

La antología de Yunque permite observar los diferentes registros en que la poesía social argentina aborda la cuestión campesina. Si se concentra la mirada en los poetas del litoral argentino incluidos en la misma, es posible apuntar de inmediato, a grandes rasgos, tres registros: el de la gauchesca, en Villanueva y Román; el del sencillismo, en Pedroni; y una veta de poesía militante más directa en Gudiño Kramer y Barrandeguy. Cierto que entre Villanueva y Román hay notables diferencias, al igual que entre Gudiño Kramer y Barrandeguy. Sin embargo, Yunque logra transmitir adecuadamente eso que todas estas apuestas tienen en común: la descripción de las costumbres del trabajador del campo o del pueblo chico. En varios casos acompañada por la denuncia de la explotación clasista (e incluso racista) a la que son sometidos por los propietarios de la tierra.

Por tratarse de una antología sin reediciones y de difícil acceso, se ha decidido trascribir en el Apéndice una serie de poemas, comenzando por «Peón de estancia» Marcelino M. Román, y «Don Escolástico Junco», más extenso, de Amaro Villanueva. La apuesta de Villanueva es más compleja y sugestiva que la de Román. En principio, porque «Don Escolástico Junco» se vuelca sobre la tradición de la gauchesca de manera reflexiva, es decir, no en lo que tiene de verosímil, en lo que toca a la lengua y los temas gauchos, sino en lo que este género tiene para dar a través del humor y la parodia. Román y Villanueva coinciden en ciertos temas - la pobreza del paisano y la crítica a la política de los conservadores con sus elecciones arregladas - y sobre todo en un horizonte de época, la 
década de 1930. Esquemáticamente, en «Peón de estancia» un peón de campo canta la lista de tareas que realiza en una estancia moderna, dando cuenta del rigor climático y la precariedad laboral, mientras que en su poema Villanueva lleva a cabo, a través de un diálogo, un repaso sobre la coyuntura política y sus raíces. Allí está el radicalismo irigoyenista y el comunismo, decidiendo entre la proscripción y el apoyo a fuerzas que los expresen en las elecciones de 1937. Elección que terminó siendo, a fin de cuentas, de las más fraudulentas y escandalosas de la historia Argentina.

Lo llamativo es que Villanueva coloca este panorama de actualidad casi partidaria en boca de un anciano sobreviviente de las batallas de Caseros y Cepeda. No es que el poeta no llegara a conocerlos, es un hecho que sí lo hizo, al igual que Ortiz. Pero su elección opera por fuera de ese dato documental, y en dos horizontes de manera simultánea: políticamente, al vincular paradigmáticamente aquellas batallas de los liberales con la actual del comunismo; y estéticamente, al inscribir ese discurso en la gauchesca, género que soporta (y requiere) ese personaje popular, el gaucho, como puntal para la trasmisión de un mensaje político específico. En la distancia que media entre la lengua del personaje y lo que el personaje dice, radica, quizás, esa torsión que Leónidas Lamborghini advierte en su ensayo «El gauchesco como arte bufo»:

Lo que en toda obra literaria trabaja en abierto misterio ante el lector poesía en acción- es el lenguaje. En el gauchesco, lo hace tensando el límite entre lo "serio" y lo "cómico": por boca de un gaucho ignorante, debe salir a ocupar los dominios de la poesía "pueblera", "culta". Esto genera el efecto gauchesco: lo bufonesco, producto de este sobreesfuerzo; lo bufonesco que ya aloja en sí mismo la torsión de la sobrecarga. Lo cierto es que el 
"espectáculo" nos convence, nos atrapa, nos domina como al rey Lear su bufón. Tanto, que hasta la lectura al pie de la letra no hace más que duplicar aquel efecto sobre nosotros. Por otra parte, el lenguaje gauchesco es un disfrazado a quien el disfraz nunca le quedará del todo ajustado: mitad hombre de la ciudad, sombrero de copa, levita; mitad chiripá, calzoncillos, bota de potro, boleadoras. Esto tiene, también, sus consecuencias. Porque la fascinación que este lenguaje ejerce se origina, asimismo, en aquel desajuste. Pasa como si por causa del mismo las palabras se pusieran a payasear y a piruetear, a disparatarse (aun en los momentos más "serios") dándose "manija", aprovechando cualquier ocasión para liberarse del encorsetamiento que deben observar en otros rediles. (Lamborghini)

Villanueva cita, en «Don Escolástico Junco», el célebre diálogo entre Jacinto Chano, capataz de una estancia en las Islas del Tordillo, y Ramón Contreras, gaucho de la Guardia del Monte. Ambos personajes emblemáticos del iniciador del género gauchesco, Bartolomé Hidalgo. Puntualmente, cita el «Diálogo patriótico interesante». Estos mismos personajes de Hidalgo realizan un contrapunto en otro de sus poemas, «Relación», sobre los festejos de las fiestas porteñas de Mayo de 1822. Pero el ápice del «desajuste» entre personajes y tema, que Lamborghini aprecia en términos de novedad estética de la gauchesca, se encuentra el contrapunto entre el paisano Laguna y el Pollo del Fausto de Estanislao del Campo, de 1866. El Pollo le refiere, en ese libro, sus impresiones de espectador ingenuo de la ópera de Gounod, que se había presentado efectivamente ese año en el Teatro Colón de Buenos Aires. 
La lectura atenta del poema de Villanueva permite apreciar, además, las continuidades ya señaladas entre su tarea de crítico y el poeta: «Bolear el anca» es, al mismo tiempo, un verso del poema y un apartado de un capítulo de su libro sobre el Martín Fierro. Ambos remiten al poema de Hernández al tiempo que sitúan a Villanueva como un investigador de la literatura y un hombre conocedor de la tradición.

Un examen en paralelo de «Peón de estancia» y «Don Escolástico Junco» permite consignar cuánto más claro resulta el mensaje del poema del primero. La protesta de Román, su enunciación, es simple y concluyente. Mientras el mensaje de Villanueva está interferido por la historiografía y por la historia de la literatura argentina. La tensión entre claridad y nivel de elaboración formal atraviesa de punta a punta la relación entre poesía y política. El paisaje del poema de Villanueva es, en esencia, y a diferencia del de Román que está situado en el ámbito de la estancia moderna, un paisaje de cultura. Tal como lo entiende Pedro Salinas (2005) en su estudio de la obra de Rubén Darío (La poesía de Rubén Darío). Solo que mientras Darío abrevó en las tradiciones griegas, romanas y del oriente, Villanueva lo hizo en la más reciente y cercana de la gauchesca.

Muy diferente es el caso del poeta santafesino José Pedroni, quien ensayó por esos mismos años un tipo singular de poesía social. Se ha mencionado, al pasar, su parentesco con el sencillismo, lo que equivale a decir con Baldomero Fernández Moreno. Carlos Mastronardi atiende a la relación entre ambos en su «Introducción» a los dos tomos de Poesía Completa de Pedroni, publicada por la Biblioteca Vigil de Rosario en 1969:

Su tono y su lenguaje no tienen parangón en nuestro medio. Con esfuerzo, con no poco artificio, podríamos mencionar a Fernández Moreno, pero esta similitud sólo aparece referida a la simplicidad de la herramienta que 
manejan. Por otra parte, Pedroni se nos revela más dotado de ternura, ya que el gran poeta ciudadano suele avenirse a la descripción del mundo físico y, por momentos, pone su intimidad entre paréntesis. Median grandes diferencias entre Fernández Moreno y el inolvidable santafesino, pero en la imposibilidad de encontrar un término de comparación acudimos al caso que nos parece más próximo. Ligamos sus nombres en razón de que ambos propenden a la sencillez, asumen un estilo libre de volutas barrocas y emplean un vocabulario cristalino que llega directamente al lector. (7)

Con su habitual sutileza crítico, Mastronardi comienza a desandar el camino que va de la analogía a la singularidad:

Asimismo, los motivos eventuales pero siempre dignos que corresponden a la llamada poesía de circunstancia se dan parejamente en uno y otro. El camionero, la iglesia nueva, el pájaro perdido que se refugia en la fábrica, el artesano a quien encuentra en la cantina, son temas ocasionales que Pedroni acoge con ánimo conmovido. Sin embargo, es fácil deslindar los predios de estos poetas: difieren en cuanto sujetos de experiencias irreductibles a un común denominador; se apartan en la medida en que viven mundos impares. Pedroni es parte de la urdimbre humana que alienta en su tierra, como si un firme proceso de integración lo hubiera unido al contexto social donde discurren sus días. Así naturalizado su espíritu, no debe sorprendernos el rápido poder de convicción que es cualidad permanente de su poesía. A poco de leerlo advertimos que se confunde y disuelve en lo suyo como el pájaro en la hondura del cielo. He aquí la causa que nos permite juzgarlo emblema y 
emanación de aquellas realidades que ganaron su intimidad melodiosa. Otro rasgo que lo muestra cabalmente es su sentimiento aprobatorio del mundo y de la vida su voluntad de reconocer y afirmar todo cuanto hay de confortador en los humanos. No escribe para deprimirnos mediante la exhibición de las zonas mezquinas del hombre, sino que hace confianza en su vocación solidaria y en los demás atributos que lo elevan. Justamente porque no adopta un punto de partida negativo, consigue lograrse como un gran poeta.

José Pedroni es oriundo de Gálvez, y pasó la mayor parte de su vida en Esperanza, ciudad que tuvo su origen en una de las primeras colonias agrarias del territorio argentino. Allí trabajó como empleado en la fundición y fábrica de maquinarias agrícolas Nicolás Schneider. En el momento en que Yunque lo incluye en su antología como otro de los poetas del descontento campesino, Pedroni ya había publicado cinco libros: La gota de agua (1923), Gracia plena (1925), Poemas y palabras (1935), Diez mujeres (1937) y El pan nuestro (1941). No resulta llamativo que los tres poemas que selecciona Yunque — «Sentido de la Iluvia», "Certificado de trabajo» y "Canto a Juan»- pertenezcan a El pan nuestro, cuyo tema, tratado de la manera en que lo definió Mastronardi, resultaba tan ceñido como novedoso: los personajes y sucesos de la fábrica de herramientas agrícolas en la que trabajó. Para los escritores de Boedo, Yunque entre ellos, la palabra del poeta-trabajador aventaja en interés - siempre en los términos de una poesía social- a la del poeta puro, pues añade, al arte, el testimonio. Sin embargo, los versos de Pedroni no apelan, como bien lo señala Mastronardi, a la piedad, menos aún a la pena, a la lástima: en síntesis, a ninguno de los elementos que caracterizan la moral de la escritura boedista. La lectura de los 
poemas seleccionados por Yunque transcriptos en el Apéndice, pueden ayudar a comprender esa eficaz mezcla que plantea Pedroni, quien realiza una poesía descriptiva, amable, pero de indudable impronta social. Se pueden leer completos los dos primeros «Sentido de la lluvia» y «Certificado de trabajo» y la estrofa inicial del extenso «Canto a Juan».

Pedroni ciñe su tema a la fábrica. Canta a los compañeros de trabajo en su rol de contador y poeta; canta la cotidianeidad de la vida de los trabajadores de Esperanza. Y su poesía se vuelve, en ese mismo acto de apegarse al recorte, cosmopolita. Pues lo singular del caso santafesino es que el acento modernizador no es exclusivo de sus dos grandes urbes. La ruralidad de la provincia es un espacio donde se encuentran y conviven múltiples culturas, tradiciones, lenguas y experiencias. Y este rasgo está magníficamente condensado en la ciudad de Esperanza. Al igual que la de Ortiz, la poesía social de Pedroni es sensible al entorno, y más apacible que combativa. Las patentes diferencias formales - la neta referencialidad de este último, el trabajo sobre la alusión de Ortiz - no empañan la posibilidad de visualizar lo que tienen en común sus búsquedas.

Si Villanueva y Román, con las sabidas diferencias, se vuelcan sobre el hombre de campo, y Pedroni hace lo suyo con el obrero inmigrante, será el también santafesino Luis Gudiño Kramer quien, por esos mismos años, se interese en los pueblos originarios del litoral argentino. En este caso los Mocovíes, pueblo diezmado por una persecución ya entonces centenaria, que sobrevivía al margen de la cultura criolla y de las culturas de los llamados «gringos». Gudiño Kramer convivió con ellos en la localidad de San Javier, que en su origen fue la antigua reducción jesuita que dirigió y retrató en acuarelas y en sus memorias Florian Paucke (2010), a mediados del s. XVIII (Hacia allá y para acá). De toda la antología de Yunque, el único poema cuyo título no está escrito en castellano, es «Labo 
Lekaike», de Gudiño Kramer, que puede leerse completo en la selección que figura en el Apéndice.

Lo que este poema tiene de esquemático en su planteo - el canto del pobre contra el rico, lo recupera con el original tratamiento del lenguaje, esa voz del mocoví de San Javier del siglo XX, mixturada con la voz criolla, que requiere, para figurarse en el imaginario del lector, de una traducción. De hecho, se incluye un vocabulario al final del poema:

Vocabulario del autor

sota guaripí: bailecito.

Labó lekaiké: casa linda.

Labó cuchuquic: casa chica.

Imec: toldo.

Loyak losók: lindo ladrillo.

Pagteghé palók: techo de paja. (30-31)

La voz del indio marginado termina exclamando en el último verso, una consigna, «sábalo asau, pa todos!». Una consigna ambigua, pues no se trata de la reivindicatoria y extendida "pan para todos», o «trabajo para todos», de los poemas sociales combativos, sino de una suerte de constatación inquietante, azorada. Sábalo es lo que hubo, hay, y habrá. Sábalo asado, el producto milenario de la pesca en el río San Javier. Pero, eso sí, no para algunos, sino para todos.

Fue Emma Barrandeguy, por su parte, quien mejor interpretó eso que arquetípicamente podría entenderse por poesía militante de corte comunista. Sin embargo, Álvaro Yunque la excluye del apartado de los «Poetas comunistas» y la ubica en el de los 
«Poetas del descontento campesino», lo cual viene a marcar, como contracara del caso de Ortiz, que la pertenencia, o más bien cabría decir la incorporación plena, no depende únicamente de las intenciones del autor, sino también de la rúbrica del aparato crítico vinculado al PCA. Sujeto, desde ya, a los avatares de las líneas políticas.

El debut literario de Barrandeguy, nada menos que en la revista Contra dirigida por Raúl González Tuñón, fue incendiario. Su extenso poema «Visión del campo argentino», plagado de autoreferencias, salió publicado en el $n^{\circ} 5$, en septiembre de 1933 . En rigor, ese fue el último número de Contra que salió a la calle antes de ser prohibida la revista y su director encarcelado. El poema completo se transcribe, para su consulta, en el Apéndice. El mensaje es directo, crudo, visceral, y el poema apela sin vueltas a la fórmula del final redentor y revolucionario. La estética está en la línea del Raúl González Tuñón de «Brigadas de choque». Poemas explosivos, antiburgueses, de largo aliento y vertiginosos al mismo tiempo. Pero la calidad de la realización no es pareja. Cosa esperable si se tiene en cuenta que Emma Barrandeguy contaba entonces con sólo diecinueve años de edad.

Barrandeguy responde, en el poema, a lo que se esperaba de un poeta militante comunista de una zona rural del litoral argentino. Al hacerlo, no es que no sea sincera. Sinceridad le sobra, si hasta es posible corroborar que ese «tibio discurso contra la guerra» del « 28 de julio» que menciona sucedió efectivamente en el salón de la Agrupación Claridad de Gualeguay, la tarde del de jueves 28 de julio de 1932, tal como se anuncia, un día antes, en el periódico Justicia de Gualeguay:

«Agrupación Claridad. Nunca más guerra! Mañana jueves a las 18:30 quedará librada al público la exposición de fotografías de la última gran guerra europea con que "Claridad" recordará el triste acontecimiento del 28 
de julio de 1914. En el acto inaugural la señorita Emma Barrandeguy hablará sobre "Aspectos del mismo tema". El salón de la exposición "Nunca jamás Guerra" está situado en calle Rivadavia y Urquiza» (Justicia sn)

Tampoco puede afirmarse que el poema carezca por completo de calidad y, por momentos, hasta de encanto. Tiene pasajes muy intensos. No se trata de una cosa ni de la otra, sino de comprobar que encaja perfectamente con la estética que reclama su lugar y su hora, y que no opera casi ningún desvío. Ataca de frente a la iglesia, a los burgueses, a la mentalidad pueblerina y conservadora. Un uso insistente de la primera persona acredita su lugar como testigo de la explotación. Pocos pasajes — salvo los dedicados a la discriminaciónrefrendan sin embargo una experiencia personal.

En cambio Tuñón sí se desvía de la norma que el mismo instaura en «Brigadas de choque». Y lo hace no una, sino reiteradas veces: "Lamento no haber sido lo que se dice "un subversivo auténtico"», o, «No importa que yo ame los puertos y los ríos», o, «El tango es una cobardía» (Las brigadas de choque 374). Son esos versos, no ya de este poema específico de Tuñón, sino como constante en su obra, los que llaman la atención de Martín Prieto (2011), quien formula esta atractiva hipótesis:

«Pero si los postmodernistas sostenían de manera un poco deforme la estructura original de los poemas clásicos, sobre todo la del soneto, González Tuñón se aleja firmemente de cualquier forma preestablecida, y el factor recordable de sus versos recordables, es decir, la nemotecnia del poema, esencial para su popularidad, se basa menos en su estructura general que en la construcción de versos sueltos que concentran la suficiente potencia como para sostener un poema entero. Esos versos-estampilla de Tuñón -“Decir, yo 
he conocido, es decir: Algo ha muerto"- que, como si fuesen clásicos desde siempre, el lector tiene la sensación de ya sabérselos cuando los lee por primera vez». (Prieto, Clarín sn)

El manejo de ese verso potente y ceñido, casi como un titular de diario (Tuñón era a su vez un notable periodista) ubica a este poeta en ese lugar "entre vanguardia y popularidad», según las palabras de Prieto. Claro que, frente a Boedo, ha operado un cambio sustancial. Se trataba, para Tuñón, de unir el camino de la vanguardia estética con la vanguardia política. Contra es, en ese sentido, una revista ejemplar para comprender las relaciones entre el PCA y la literatura argentina en la primera mitad de la década de 1930. El trabajo de Silvia Saitta (2005) «Polémicas ideológicas, debates literarios en Contra. La revista de los francotiradores» enmarca estos debates y complejiza está aventura de Tuñón como editor, poeta y ensayista, y su relación con el Partido:

González Tuñón busca ser comprendido, pero a través de la confrontación: es comunista, pero sin carnet de afiliación; es comunista pero no por eso pone su arte bajo las directivas del partido. Su desafío encuentra quien lo escuche: Carlos Moog, voz oficial del Partido Comunista en cuestiones vinculadas al arte y la literatura, si bien elogia "la valentía” de González Tuñón, considera que sus argumentos son "una confusión muy pequeño-burguesa" porque, en primer lugar, son los trabajadores y no los intelectuales los que han de crear esa conciencia revolucionaria; y en segundo lugar, porque esa conciencia revolucionaria que González Tuñón propone crear a través del libro, el diario y la revista sólo podrá ser creada a través de la acción y la propaganda de los partidos comunistas. (Saitta) 
Aún con estas idas y vueltas, Contra es uno de los emblemas culturales comunistas que mejor caracterizan la estrategia de Lucha de Clase. Es decir: pleno enfrentamiento con los demás partidos burgueses, no solo el conservador que tenía el poder, sino también el radicalismo y el socialismo. "Las brigadas de choque», un poema manifiesto, lo dice sin vueltas en la estrofa final:

Contra en la casa

Contra en el mar

Contra en la calle

Contra en el bar

Contra en el campo

Contra en la montaña

... Para abatir al imperialismo.

... Por una conciencia revolucionaria.

-y aquí nosotros contra la histeria fascista-

contra la confusión radical,

contra el socialismo tibio.

Contra

contra

estar en contra

sistemáticamente contra

contra

Yo arrojo este poema violento y quebrado

contra el rostro de la burguesía. (374-75) 
La defensa que Tuñón realiza en el último número de la revista Contra -el mismo en que aparece el poema transcripto de Emma Barrandeguy - frente a los ataques policiales de los que fueron blanco el propio poeta y los algunos lectores de la revista, sirve para situar, una vez más, sus aspiraciones, y la extrema aspereza del discurso esgrimido:

La policía — como se consigna en un suelto de "El Mundo" - detuvo a varios lectores de Contra, obreros chauffeurs y del frigorífico Anglo. Nada de eso pudo saberse al principio, hasta que los empleados de Orden Social cometieron la torpeza de detener a un periodista... y de "El mundo". ¡Bonita manera de interpretar las leyes! Hacen bien —como decía un cronista - al detener a los lectores, puesto que si la Constitución habla de libertad de imprenta, ningún artículo se refiere a la libertad de lectura... Pero ¿por qué la policía pretende acallar nuestra voz, mientras deja que todos los días un ex procesado por corrupción de menores, Leopoldo Lugones, hijo, chille pestes contra el presidente de la República en el pasquín del mediocre ex anarquista Carulla? Es que para nuestra policía, policía de clases, no son enemigos los legionarios, los fascistas, los ultra nacionalistas, EXPRESION AGRESIVA DE LA CLASE BURGUESA, y sí los que opinamos que este sistema es un sistema podrido, y sí los que soñamos con un mundo donde no haya ni opresores, ni oprimidos y sí los que defendemos a la URSS, porque la URSS es el primer país de los trabajadores, y la esperanza de todo el mundo. (420-421)

De manera esquemática, podría afirmarse que el programa estético de esta etapa de Emma Barrandeguy se sintetiza en un solo verso-consigna de Tuñón: «Contra en el campo». 
Barrandeguy está plenamente dispuesta a hacerse cargo de los temas vinculados a los campesinos y obreros de la región de Gualeguay desde una perspectiva combativa y clasista. A pocos kilómetros de esta ciudad, camino a Puerto Ruiz (puerto fluvial que conecta con el río Paraná y pueblo natal de Ortiz), se encuentra el frigorífico al que refiere, precisamente, el poema «Frigorífico» que se transcribe en el Apéndice.

Los dos poemas citados de Barrandeguy — «Visión del campo argentino» y «Frigorífico»— alcanzan para tener un panorama de cómo aborda la injusticia de la vida rural y obrera entrerriana bajo el gobierno del régimen conservador, específicamente el de Agustín P. Justo. Una coyuntura que, como se ha indicado ya, era verdaderamente desgarradora por los niveles de pobreza y desprotección de las clases trabajadoras. Podemos, a través de estos poemas, hacernos la idea del drama y la faena de los obreros de la carne; al igual que podemos reconstruir el de los obreros y colonos de Esperanza en Pedroni; el grado de desprotección de los mocovíes en Gudiño Kramer; el de los peones de estancia y los paisanos en Román y Villanueva. De alguna manera, y con las notorias variantes consignadas, todos ellos se sitúan en el corazón del drama de la clase trabajadora de la región, refiriendo sus condiciones de vida y trabajo. En la mayoría de los casos además de denunciar la injusticia dan el paso de acusar al régimen que la origina.

Lo cual permite poner en perspectiva el desvío que opera la escritura de Ortiz en esa misma época y en esa misma región. Una poesía social que no hace uso ni mención de los temas y protagonistas que, casi fatalmente, la componen. En otras palabras: ¿Cómo puede ser comunista una poesía que no tiene, salvo contadas excepciones, peones, ni campos arados, ni maquinas trillando? ¿Cómo puede ser comunista una poesía que habiendo sido producida en el centro mismo de la actividad de explotación de ganado no tenga vacas pastando, ni mataderos, ni obreros, ni frigoríficos, ni barcazas que partan por el río con las 
jaulas llenas de animales? Siendo, como es evidente, qué todo esto ocurría y aparece efectivamente reflejado en la obra de sus camaradas y compañeros de ruta.

El caso de José Portogalo

El recorrido literario del poeta José Portogalo no tuvo uno, sino dos comienzos. El primero, el que corresponde propiamente a su debut, fue en el año 1933 con Tregua, libro que apareció en la Colección «Los Poetas», de la Editorial Claridad. El dato de quiénes lo publicaron no es menor. La búsqueda inicial de Portogalo se concentraba en un estrecho ángulo que le permitía filtrar, a través del patrón formal y sentimental del posmodernismo, la temática social. En versos medidos, haciendo uso de un vocabulario amplio y por momentos exótico, el poeta cantó a los vendedores de diarios, a los pintores, a los trabajadores de la fundición. Se transcriben las primeras estrofas de «Albañiles»:

Albañiles

Vigoroso hemisferio de luz en los andamios.

Torsos que se revelan sobre la piel del aire en toda su potencia magnífica y creadora; anónimos perfiles que amedallan la altura avivando el incendio del sol en las ciudades y enfrentando la sórdida presencia de la lluvia. 
Con despaciosos giros de péndulo oscilante

sus flexibles cinturas recortan el espacio

como si al gesto torvo del día le arrancaran

calladas y maduras jornadas de trabajo.

Cuando bajan los soles a tatuarles los ojos

sus voces suman cantos al pentagrama rudo

del esfuerzo, que es música matinal y sonora,

como el repiqueteo de campanas festivas

arqueadas entre el puño y un dominio de sombras. (Poemas 22-23)

Hijo adoptivo de un inmigrante jornalero, ducho desde niño en los rubros más duros del trabajo, lo cual le había impedido terminar la escuela, Portogalo desplegó en Tregua, de manera ejemplar, la amalgama entre vida y obra que promovía como bandera el grupo de Boedo. Era un poeta obrero, un hombre redimido cuyos versos podían medirse con los de cualquier poeta de oficio; pues era en esa perspectiva, en el horizonte de la alta cultura, que habían sido facturados.

Distinto es el otro comienzo que ensayó Portogalo. Fue con Tumulto, publicado en Buenos Aires por la editorial anarquista Imán, en noviembre de 1935. El libro reunía un conjunto de veinticinco poemas, acompañados por ilustraciones y grabados del artista plástico Demetrio Urruchúa. Tumulto fue el segundo de los libros de José Portogalo, pero tan grande es la brecha que lo separa de Tregua, tan desmesurado el modo en que divergen sus formas y sus intenciones, que es difícil resaltar algún tipo de continuidad, por fuera de 
una nominal coincidencia de los temas de interés y algunos poemas medidos que sobreviven, según parece, sólo para marcar la excepción.

La imagen, ante este segundo libro de Portogalo es la de un autor que no solo ha barrido las piezas del tablero y la ha emprendido contra el tablero mismo. Una línea iconoclasta recorre Tumulto, lo tensa, lo lleva de continuo hacia las fronteras de lo que en su época se entendía por poesía. Aparece la urgente y clara prosa narrativa, la propaganda directa, la puteada, el discurso radiofónico, etc.

Se trata de indicar que Tumulto no fue un desvío de la ruta trazada por Tregua, sino un camino completamente nuevo e inexplorado. Son varios los factores que apuntalan la originalidad intrínseca del libro. Conociéndolos, podrá comprenderse con mayor claridad su posterior recorrido, que incluye el premio en el Concurso Municipal de Literatura de Buenos Aires de 1935, su inmediata y escandalosa prohibición, el secuestro de los ejemplares distribuidos por parte de los agentes del intendente de Buenos Aires, Mariano de Vedia y Mitre, las sentencias judiciales, y un prolongado silencio editorial que duró hasta el año 2012.

¿Qué pudo haber ocurrido en aquel año y medio que separa los dos libros como para que se produzca un cambio tan significativo? ¿Fue una reacción espontánea de Portogalo, o hay factores que permitan explicarlo? Tumulto, como libro, carece de antecedentes reconocibles en el país. Sin embargo, puede notarse alguna familiaridad con «Las Brigadas de Choque»: poema vanguardista, dinámico, en verso libre y sin rimas, desprejuiciadamente militante. En esa condición de posibilidad del poema, se cuenta un primer antecedente para Tumulto. La amistad, además de una innegable fraternidad poética y política vinculada a la sociabilidad que rodeaba al Partido Comunista Argentino, unía a estos poetas. 
El otro gran antecedente que propicia un nuevo comienzo desde cero en la poesía de Portogalo, es su lectura de poetas norteamericanos como Langston Hughes y Carl Sandburg. En sus Poemas de Chicago, de 1916, este último mostraba que todo podía ingresar en la poesía, sin necesidad de traicionar el universo obrero, ni el pulso de las grandes urbes. Walt Whitman flotaba en sus poemas, y en el camino del verso libre, en la búsqueda del ritmo propio, aparecía impreso el orgullo del self-made-man. Esto sí resultó modélico. Casi una fascinación para Portogalo, él mismo un self-made-man, tanto que dedica a Sandburg el séptimo poema de Tumulto, «: «Cómo me gustaría haberme hallado en tus años/ junto a tus manos pesadas, ásperas, violentas/ porque con ellas has hecho todos los oficios -como yo- y has escrito poemas» (Tumulto 33).

El sentimiento democrático, de orgullosa igualdad, que impregna esta poesía norteamericana, es en buena medida el basamento moral de Tumulto. Es un cambio de grandes dimensiones. Ya no se trataba de ser el obrero redimido que cantaba como cantan los poetas de oficio, ni de llegar a manejar el lenguaje culto de la alta poesía. No era necesario ningún salto, ni progreso, sino más bien lo contrario, mirar alrededor, a Villa Ortúzar, a la ciudad que dejaba atrás el paso del carro, cantar lo que se veía sin formulas ni pretensiones, y darse libertad para que las mismas cosas establezcan su ritmo.

Tumulto se publicó a principios de noviembre de 1935. La plena libertad de la poesía de Portogalo hallaba su correspondencia en el singular trabajo realizado para el libro por Demetrio Urruchúa. El pintor y muralista, que años más tarde fundaría junto con Antonio Berni, Lino Enea Spilimbergo y Manuel Colmeiro el Taller de Arte Mural, realizando los frescos que aún se pueden ver en las cúpulas de la Galería Pacífico de Buenos Aires, logró plasmar en quince pequeñas escenas, con el uso sintético de la línea, el espíritu de Tumulto. Sus burgueses gordos con bastón, sus prostitutas, sus soldados armados, el entierro 
desolador de un albañil, el baile de una pareja con los torsos desnudos, entre otros personajes, perfilan con potencia expresiva, plástica, el mundo en plena ebullición de Tumulto.

El formato amplio y apaisado de la edición original no es caprichoso. Cumple, al menos, dos funciones. Por un lado, admite esos versos extraordinariamente largos que abundan en los poemas. Por otro, sirve de soporte a los tres formidables grabados de Urruchúa que aparecen impresos a página completa. Permite admirarlos a un buen tamaño. El surgimiento sorpresivo y un tanto aleatorio de estos, genera una pausa, un rellano, un obligado descanso visual. Tumulto se abre entonces hacia una experiencia nueva, pasa de lo literario a lo pictórico. El lector ya no lee, sino que ve.

No está demás mencionar que el resultado de ese dialogo de lenguajes figura entre los méritos mayores del libro. Pues no se detiene allí. En un giro quijotesco, Urruchúa, el pintor, aparece como personajes de poemas que él mismo está ilustrando. En «Poema mural» y en este pasaje de «Un poema a las 6 de la mañana»

Mi ciudad: La de las grandes riquezas y las grandes miserias La de los grandes chantajistas de guante color patito:

Gerentes de banco. Presidentes de asociaciones patrióticas. Directores de grandes rotativos. Críticos de Arte. Periodistas.

Urruchúa los pintaría con una ganzúa en los labios o colgados de unos mechinales con una soga al cuello.

¿No es cierto Urruchúa? -Urruchúa es el más grande pintor de mi ciudad. 
Paralelamente a la publicación del libro, José Portogalo envía una copia al Concurso Municipal de Literatura, el mismo que habían ganado en su momento Tuñón y Jorge Luis Borges. Por aquel entonces, el primer premio era de 5000 pesos, el segundo de 3000 y el tercero de 2000. Para tener una medida, Tumulto lleva impreso el precio en la contratapa: \$1 por ejemplar. Se trataba, sin dudas, del premio más importante y prestigioso de la Argentina.

El 8 de noviembre de ese mismo año, aparece en el diario La Nación una breve nota mencionando que los autores participantes del certamen se habían reunido, y habían elegido a Cesar Tiempo para representarlos dentro del jurado. A esta singularidad del concurso, hay que sumarle otra, la presencia en calidad de jurado de un concejal oficialista, en caso el conservador Lizardo Molina Carranza, y un concejal socialista, Juan Unamuno. La lista de jurados se completaba con Leopoldo Marechal, el poeta Horacio Rega Molina, Arturo Giménez Pastor y Salvador Oría.

Once días más tarde, otra nota en el mismo matutino informa de una reunión en el despacho del Secretario de Hacienda porteño, en la cual el jurado constituido había designado como secretario a Cesar Tiempo, además de distribuirse las más de sesenta obras presentadas.

Naturalmente, cabe preguntarse qué chances tenía en ese concurso oficial un libro como Tumulto, con sus muchachas de barrio desnudas panza arriba a punto de ser poseídas por sus amantes furtivos, sus generales que miran angelitos invertidos con apetito sexual, sus insultos a los burgueses, sus monjas calientes, sus proletarios rebeldes y las valijas de los viajeros católicos cargadas de dinamita (el año anterior se había celebrado en Buenos Aires el multitudinario Congreso Internacional Eucarístico). Se necesitaba poco menos que un milagro para conseguir que triunfe. 
Allí es donde interviene Cesar Tiempo, a la sazón secretario del jurado y amigo personal de Portogalo. Había sido él quien cinco años antes lo presentara a Antonio Zamora, director de Editorial Claridad, de cuyo vínculo surgió la publicación de Tregua y las múltiples colaboraciones del poeta en la revista Claridad. La inagotable veta bromística de Tiempo, que ya había engendrado a la poetisa Clara Beter (operación que fuera deschabada, como se indicó, por Carlos Serfaty), retornaba una vez más para darle un giro imprevisto, novelesco, a los hechos.

Desde un principio, según relata Tiempo mismo en una nota de homenaje a Portogalo publicada el 2 de julio de 1972 en el diario La Opinión, sostuvo dentro del jurado que el tercer premio de poesía debía ser para Tumulto. Otros miembros se inclinaban por un libro de Jorge Obligado, hermano de Carlos, poeta de posición económica desahogada. El argumento de Tiempo, muy boedista por cierto, era que el Premio Municipal debía servir de estímulo a ciudadanos que, como Portogalo, se ganaban el pan con el sudor de su frente, además de escribir versos. Era un modo ejemplar de inducirlos a perseverar en el camino de la cultura. Consiguió el voto de Rega Molina y Unamuno. Un voto más, y el premio sería para Portogalo. La discusión parecía estancarse, enfrentando a Tiempo con quienes no les importaba en absoluto el origen del autor y fijaban en cambio su mirada en el valor intrínseco de la obra. En un momento - siempre siguiendo el relato de Tiempo-Molina Carranza, el concejal conservador, lo frena y le pregunta si había leído el libro. Rápido de reflejos, Tiempo advirtió que cabía la posibilidad de que su interlocutor no lo hubiese hecho. «¿Cómo no lo voy a leer? - asegura que le contestó- Es sensacional. Poesía auténtica». La respuesta, decisiva, selló el destino del premio: «Yo lo voy apoyar", dijo Molina Carranza. El jueves 23 de abril de 1936, La Nación publicó una extensa nota con los resultados del concurso, encabezada con el retrato fotográfico de los ganadores. Uno solo sonreía. Era 
José Portogalo. El joven «obrero y poeta», tal como se lo definía, había obtenido finalmente el tercer premio de poesía del Concurso Municipal de 1935. «El Sr. Portogalo — proseguía la noticia - canta con espíritu rebelde la ansiedad de los proletarios, en versos fogosos y a veces encendidos de fiebre revolucionaria».

En nota ya citada del diario La Opinión, Cesar Tiempo reconstruye lo que falta:

Al día siguiente la noticia del premio se publica en La Nación. De Vedia y Mitre (intendente de Buenos Aires) lo llama enseguida a Molina Carranza, que era concejal de su partido, y le dice:

Le voy a leer una poesía, ¿qué le parece?

Y le lee un poema de Tumulto donde Pepe se orinaba en las pilas de agua bendita, y otros exabruptos por el estilo.

¡Esto es un horror, caramba! - exclamó Molina Carranza.

No sólo es un horror - le respondió de Vedia y Mitre-, sino que, además, usted lo ha votado para uno de los premios municipales. ¿Cómo es eso, concejal? Lo ha estimulado con dineros de la Municipalidad ¿Cómo es eso? Retiro la firma iretiro la firma! (El Jabalí 37-38)

El alcance del chasco fue formidable, pero también sus consecuencias. El intendente, que aparece mencionado en el libro, pues tenía reputación de hombre de letras, hizo del caso una causa ejemplar. Ordenó a los agentes municipales secuestrar los ejemplares de las librerías y entabló un tenaz acoso judicial contra el autor. El motivo aducido era el de «ultraje al pudor». No iba a tolerar el erotismo obrero de Tumulto. Pero eso no era todo. Bajo el manto de esa acusación escandalosa, se escondían los otros ultrajes del libro. El ultraje a la imagen de la capital pujante en «Habitante de Buenos Aires»; a la Iglesia, a Cristo 
y a Dios en «Mitín»; a la poesía en «En poema escrito en el puño de mi camisa»; a la burguesía, al ejército, a los trust multinacionales, a los radicales, a la democracia y sus buenas costumbres en «Cartel» o en «Poema caminando». En el Apéndice puede leerse, íntegro, este último:

En noviembre de 1937 aparece una solicitada de apoyo a Portogalo en la revista Unidad, que dirigía Rodolfo Puiggrós. Llevaba la firma de Emilio Troise, secretario de la AIAPE. La declaración, de la que se transcribe un pasaje, repone, además de los datos de la acuciante situación de Portogalo, el verdadero motivo de la persecución que se hacía alusión en el párrafo anterior a la cita del poema:

Ignoramos si pertenece a Partido o credo determinado. Conocemos su libro y su talento, simplemente. Y es ese libro y ese talento, lo que se procesa y persigue enmarañando tendenciosamente los conceptos, podando esperanzas y nivelando mediocremente las ideas. Condenado por la justicia a sufrir un año de prisión, en forma condicional, aun no se termina ese trámite. Se abre un nuevo juicio para privarlo de su ciudadanía argentina. Y ahora ya no se trata de un poeta, ni de un libro. Se trata de un hombre, cuya cédula de identidad se resume en estos términos: José Portogalo, 33 años de edad; 29 de residencia; 15 de ciudadanía (Troise).

Portogalo debió abandonar Villa Ortúzar, el barrio porteño que está en el centro de Tumulto. Vivió un tiempo en Córdoba, otro en Rosario, y luego, cuando ocurrió La revolución de Junio de 1943, se exilió en el Uruguay, donde trabajó como periodista. No dejó de escribir, ni de publicar, pero su poesía, en un nuevo giro, retomó el rumbo de Tregua. No es difícil inferir que el escándalo y la persecución hayan hecho mella. De manera 
incidental, puede haber contribuido el cambio de estrategia del PCA, que obturaba, al interior de sus filas - a las que Portogalo ya para entonces pertenecía-, la insistencia en una estética de franco ataque a las fuerzas burguesas. El poeta retornó al verso medido, a un lenguaje más convencionalmente en línea con el postmodernismo.

En 1939, publica bajo el sello de la AIAPE su cuarto libro de poesía. Una suerte de cancionero infantil titulado Canción para el día sin miedo. Ya en la primera estrofa del poema «Para empezar», que abre el libro, puede percibirse el cambio estético operado:

Para empezar

Un país y una estrella desatada.

Oh, amigos y qué lluvia de canciones, de alegres, repartidas golondrinas, de muchachas, de risas y ternuras. Y qué ríos, qué insectos, qué ventanas, qué varonil empuje y musgo fresco. Y un país, un país de primavera, con unos cuantos niños callejeros y una estrella rodando en cada esquina (Canción para el día sin miedo 7)

Tumulto se posiciona, en vistas de la obra del poeta, como un libro aislado. Tan profundo cala esta conciencia de la diferencia que queda afuera de la antología Poemas (1933-1955), que reunía la «totalidad» de sus libros publicados hasta el momento. Si, tal como lo declara Emilio Soto en la introducción al volumen, se trata de una autoantología, es dable inferir en Portogalo alguna clase de arrepentimiento respecto de Tumulto, cuya marca sería la 
perpetuación en el tiempo - ante reiterados ofrecimientos - de la negación de volver a editarlo.

El hijo de Portogalo, el también poeta José Ananía, indicó en entrevistas personales realizadas en el marco de esta investigación, que ya a finales de los treinta había un acercamiento y una confesa admiración de Portogalo hacia Ortiz y su obra. Notoria incluso, siempre según él, en el rumbo de la búsqueda poética de Portogalo posterior a Tumulto. Ananía aportó, por otra parte, una valiosa carta de su archivo familiar, enviada por Ortiz a su padre el 16 de marzo de 1939:

Gualeguay, marzo 16 de 1939

Querido Portogalo:

Recién puedo contestar su carta. No tenía gallinas. Me las robaron. Encargué a un hombre me consiguiera un casal de legos. No sé si serán muy puros. Es la raza que más le conviene a sus viejos porque es la más ponedora. Deseo no queden del todo insatisfechos.

Me excusarán esta demora en cumplir con mis compromisos. La dicha persona ha andado muy lenta y yo ocupadísimo en menesteres militares ihorror! imprescindibles para mis escapadas a esa. Por Mastronardi sé de sus dificultades económicas y del pequeño alivio que ha logrado, causándonos esto último una íntima satisfacción. Lo del premio no me ha preocupado mayormente, pero agradezco a los amigos todo lo que han hecho por él. Ud. comprenderá que algunos viajes más no pueden se[r] decisivos en nuestra necesidad más profunda: la expresión lírica, fuente de nuestras alegrías y dolores más vivos, y forma 
también, no tan intrascendente como se cree, de nuestra participación en la lucha por un mundo mejor. Esto último es lo que más me preocupa, dentro de los límites, se entiende, de la más estricta fidelidad a mí mismo, o a lo que yo siento como más mío. Excúseme este tono quizás demasiado individualista en esta época que exige nuestra entrega total a cosas más sencillas y grandes que una mera realización personal por menos egoísta que ésta sea. $\mathrm{D}$ [é] mis abrazos a todos y mis afectos especiales a su compañera y a sus padres.

Hasta semana santa en que tendré la alegría de verle, he de resignarme al mensaje cariñosísimo de la presente:

\section{J.L.Ortiz}

PD: Va la guía.

Esta carta cuenta como documento de la relación entre Ortiz y Portogalo hacia finales de la década de 1930. Pero sobre todo permite conocer de la propia pluma de Ortiz su postura acerca del valor militante de la expresión lírica: «una forma también, no tan intrascendente como se cree, de nuestra participación en la lucha por un mundo mejor».

\section{La poesía comunista internacional: Cesar Vallejo y Raúl González Tuñón}

La Guerra Civil Española tuvo lugar entre julio de 1936 y abril de 1939. Se trató de un conflicto social, político y bélico de enorme trascendencia dentro de la historia mundial del siglo XX, con un impacto particularmente fuerte en América Latina. El grado de desarrollo tecnológico que habían alcanzado algunos medios masivos de comunicación como la radio y 
los diarios lo convirtieron en el foco de interés de una enorme masa de público de todo occidente, incluida, por supuesto, América del Sur. La Guerra Civil provocó una inmediata división. Los bandos en pugna, es decir, los republicanos por un lado y el ejército del General Francisco Franco por otro, aglutinaron las diversas fuerzas o poderes que ya venían dando batalla. Para los republicanos, liberales, anarquistas y comunistas de todas las latitudes, la guerra de España se convirtió en un símbolo de la lucha para detener el evidente avance del fascismo. La política de «no intervención» en el conflicto adoptada por Francia, Inglaterra y los Estados Unidos, pesaban menos, en la evaluación del conflicto, que el efectivo apoyo que brindaron a las fuerzas de Franco dos poderosos estados totalitarios, como la Italia de Benito Mussolini y la Alemania de Adolf Hitler. Para los conservadores, liberales protofascistas y buena parte de los sectores vinculados a la Iglesia Católica, se trató de una verdadera lucha por recuperar el poder y las tradiciones que el gobierno republicano había desterrado en pocos años. Como trasfondo circulaba, de ese lado de la barricada, el fantasma de la internacionalización del anarquismo y el comunismo. Esgrimían como prueba el apoyo que la Unión Soviética brindó a la Segunda República, más allá de las consabidas idas y vueltas.

El conflicto de España trajo una serie de novedades respecto de su antecedente inmediato, la Gran Guerra de 1914. El enorme desarrollo que se dio entre aquel año y 1936 en la aviación, en la artillería, en la tecnología de los tanques, coincidió con un avanzadísimo grado de radicalización ideológica. No se peleaba por una nación, se peleaba por una forma de vida. Por las cosas que se amaban, por las cosas que se deseaban, en contra de las personas que se odiaban. Ese cóctel conformó un trágico panorama, pues la guerra no se dio entre ejércitos regulares. Los civiles alistados voluntariamente al Ejército Popular de la Segunda República se enfrentaron con las fuerzas militares, los sicarios y la «quinta 
columna» del General Franco, esta última formada por los civiles españoles que estando en territorio de la Segunda República apoyaban a las fuerzas invasoras. El campo de batalla se desplazó a las ciudades. El bombardeo de Guernica es un caso de las atrocidades cometidas contra blancos civiles. La retaguardia, allí donde se suponía que los niños, los ancianos y las mujeres de los soldados debían aguardar, distaba de ser un lugar seguro. Nadie quedaba a salvo y las imágenes de aquel horror dieron la vuelta al mundo. Las posiciones a favor de uno y otro bando no tardaron en volverse, como la misma guerra, extremas.

Casi sesenta mil voluntarios comunistas, anarquistas y republicanos de cincuenta y cuatro países partieron a España para conformar las Brigadas Internacionales. Aquellos que se quedaron, tuvieron una participación activa a través de la organización de comités de apoyo y amplias redes de sociabilidad. Pero tal como señala Niall Binns (2004), quien ha estudiado minuciosamente y en toda su extensión el impacto de la Guerra Civil sobre la literatura de Occidente:

Se trataba no sólo de una lucha entre la civilización occidental y el comunismo o entre la democracia y el fascismo, sino de una lucha muy hispánica, y muy familiar para todos los países hispanoamericanos: una lucha a favor o en contra de la reforma agraria, de la reforma educativa y de la limitación del papel de la Iglesia y el Ejercito en la sociedad. La gran mayoría de los países [de Hispanoamérica] tenían gobiernos autoritarios de derecha: es el caso, por ejemplo, del general argentino Agustín P. Justo, del uruguayo Gabriel Terra, del chileno Arturo Alessandri, del general peruano Oscar Benavides, del ecuatoriano Federico Páez y del general guatemalteco Jorge Ubico. (La llamada de España 16) 
El único estado de nuestro continente que intervino decididamente a favor de la Republica fue México. El presidente Lázaro Cárdenas dio apoyo militar, económico y diplomático a España, enfrentándose, en este último aspecto, al Comité de No intervención al comando de las grandes potencias democráticas occidentales.

La Guerra Civil Española tuvo un inmenso impacto cultural. La literatura de las distintas latitudes se vio necesariamente afectada por el conflicto. Pero ninguna alcanzó el grado de conmoción sufrido por la poesía escrita en lengua española. Tal como asegura Pablo Neruda: «No ha habido en la historia intelectual una esencia tan fértil para los poetas como la Guerra Civil Española. La sangre española ejerció un magnetismo que hizo temblar la poesía de una gran época» (42). Y agrega Binns al respecto:

Otra clasificación pertinente corresponde a los géneros literarios. Stephen Spender definió la guerra civil como una "guerra de poetas". Lo fue en cierto sentido. La muerte de Lorca, el poeta español de mayor proyección internacional, permitía entender - simbólicamente- que Franco y sus aliados fascistas representaban el repudio y el silenciamiento de la poesía. En este sentido, escribir sobre la guerra significaba, para un poeta, luchar contra el fascismo, y hubo una intensa e inmensa producción poética sobre la guerra civil no solo en España sino en todos los países de Occidente. Por otra parte, la recuperación de la forma del romance -ya popularizada por Lorca con su Romancero gitano - tanto por poetas cultos como por anónimos milicianos en el frente, tuvo gran impacto en América y conectaba con los esfuerzos "popularizadores" de poetas como Raúl González Tuñón y el estadounidense Langston Hughes. Si la poesía fue el género literario más importante de la 
guerra, es porque seguía conservando un prestigio que resulta en nuestros días inconcebible: Vicente Huidobro, como Rafael Alberti y Miguel Hernández, leyeron sus poemas, y casi todos los poetas de lengua española buscaban para sus versos una contundencia y una claridad aptas para la comunicación y la declaración. (21)

Siguiendo a las clasificaciones que el mismo Binns realiza en sus dos libros escritos sobre el tema, el citado volumen de ensayos La llamada de España. Escritores extranjeros en la Guerra Civil, de 2004, y su antología de 2009, Voluntarios con gafas. Escritores extranjeros en la Guerra Civil, se pueden agrupar a los escritores extranjeros que reaccionaron frente al conflicto en cinco grandes grupos. El primero está formado por aquellos que se sumaron y combatieron en las ciudades y los campos:

El húngaro Mate Zalka, los alemanes Gustav Regler, Ludwig Renn y Alfres Kantorowics, el holandés Jef Lasto, el irlandés Charles Donelly, los británicos John Cornford, Christopher Caudwell, John Sommerfield, Ralph Bates, Humphrey Slater, Ralph Fox y Laurie Lee, y los norteamericanos Edwin Rolfe y Alvah Bessie, todos participaron en las Brigadas Internacionales. André Malraux organizó la Escuadrilla España; Pablo de la Torriente Brau luchó en el batallón del Campesino; George Orwell con las milicias del POUM; Benjamin Péret y Simone Weil con los anarquistas. (Voluntarios 31-32)

Una frase de Ludwig Renn en el Congreso de Escritores de 1937 resume perfectamente el espíritu que animaba a este grupo: «nosotros, escritores del frente, hemos venido dejando la pluma parada; no queríamos más escribir historia, sino hacer historia» (32). 
El segundo grupo está formado por los congresistas, o, como los bautizó Mikhail Kolstov, los voluntarios con gafas. Agrega Nills:

Al Segundo Congreso Internacional de Escritores para la Defensa de la Cultura —el Ilamado "Congreso de Escritores Antifascistas", coordinado por Rafael Alberti y José Bergamín con la colaboración rusa de Kolstov e Ilya Ehrenburg y celebrado en julio de 1937 en Valencia, Madrid, Barcelona y Parísacudieron más de cien intelectuales en una manifestación antifascista única en la historia. Se ha cuestionado la categoría de muchos extranjeros invitados, pero vinieron escritores tan importantes como Malraux, Spender, la alemana Anna Seghers y el norteamericano Langston Hughes, y brillaba sobre todo la cantidad y calidad de los hispanoamericanos. Pablo Neruda, que había dejado su puesto de cónsul chileno en Madrid por involucrarse activamente en la lucha de la República, trabajó en París en la organización del Congreso, encargándose de las invitaciones a escritores de "nuestra América", a algunos ya consagrados y otros todavía muy jóvenes. Vinieron, entre otros, los mexicanos Carlos Pellicier y Octavio Paz, lo cubanos Nicolás Guillén, Juan Marinello y Alejo Carpentier, el argentino Raúl González Tuñón, el peruano Cesar Vallejo, y de Chile (aparte de Neruda) Vicente Huidobro y Alberto Romero. Todos ellos suscribieron el documento "Apelación desde Madrid a los escritores hispanoamericanos", donde hablaban de su experiencia en España, denunciando los ataques fascistas a la cultura e insistiendo en su deber humano como intelectuales: "España es el futuro de Hispanoamérica. Trabajando por el triunfo de España trabaja el escritor 
nuestro por el triunfo de Hispanoamérica, al mismo tiempo que realiza una obra de la más amplia y pura superación humana. Que la realice cada día con más entusiasmo y conciencia. Lo pedimos desde Madrid la heróica, asombro de la tierra y honor del linaje humano". (31-32)

Un tercer grupo reúne a los testigos involuntarios, que se encontraban eventualmente o vivían en España y participaron activamente. Neruda es el caso emblemático, pero algo similar ocurrió con sudafricano Roy Campbell; el inglés Laurie Lee; el francés George Bernanos y el novelista ecuatoriano Demetrio Aguilera-Malta, entre otros.

El cuarto grupo lo conforman los periodistas. Escritores que actuaron como corresponsales de Guerra para diarios y revistas de sus países de origen. Entre ellos se encuentran los norteamericanos Ernst Hemingway y John Dos Passos, que trabajaron en el documental The Spanish Earth, y a su compatriota Lanston Hugues, que llegó con la misión de escribir sobre los participantes negros de la guerra. También Antoine de Saint-Exupéry, los rusos Koltsov y Ehrenburg y el que, según asegura Nills, resultó ser el periodista más célebre de la guerra, el húngaro Arthur Koestler, que trabajaba para el londinense News Chronicle.

El último grupo de escritores se encontraba fuera de España, disperso en el resto de Occidente. La definición de Nills es precisa:

Existían en todos los países otro importante grupo de escritores que podríamos llamar los de la Lejana Retaguardia, que tomaban partido, muchas veces apasionado, en esta guerra civil que se había transformado en una guerra internacional. Paul Claudel, Jaques Maritain y Françoise Mauriac debatían desde Francia sobre la postura de la Iglesia en España; Upton 
Sinclair desde Caliornia publicaba No pasaran!; los alemanes Bertolt Brech y Hermann Kesten escribían desde el exilio, sintiendo en España un reflejo de lo que había vivido ellos en Alemania. (Voluntarios 34)

A esta lista de Nills habría que sumarle, para el caso de la Argentina, buena parte de los poetas e intelectuales de la cultura vinculados a la AIAPE, y también aquellos que rodean la redacción de la revista Claridad. De hecho, la mencionada antología Voluntarios con gafas. Escritores extranjeros en la Guerra Civil, incluye dos poetas de la «Lejana Retaguardia» Argentina: Conrado Nalé Roxlo y Juan L. Ortiz. El primero con un homenaje a Federico García Lorca publicado en la revista Sur; el segundo con "A los poetas españoles», aquel poema incluido en la antología del uruguayo Ildefonso Pereda Valdés, Cancionero de la Guerra Civil Española , editado por el Comité Pro-Defensa de la República Española, en 1937.

Ese mismo año, Álvaro Yunque publicó, en Buenos Aires, España: 1936. Se trata de un poemario de lenguaje llano y clara intención militante, tal como puede leerse en las primeras estrofas de «U. H. P.».

U.H.P.

U. H. P. : "Uníos, Hermanos Proletarios", unidos, proletarios, unidos, siempre unidos, como contra el incendio os uniríais, como contra la peste, proletarios, juníos!

No hay más que una palabra de orden, proletarios, no hay más que una consigna, proletarios: ¡Uníos!, 
que todos seáis uno,

porque es uno también el enemigo.

Nadie pregunta a nadie lo que piensa

cuando llega el peligro:

junta su esfuerzo con el del más próximo

y su coraje con el del vecino.

Llega el incendio, llega la peste, proletarios,

Coraje, esfuerzo y iea, todos contra el fascismo! (España: 1936 sn)

La consigna «Uníos Hermanos Proletarios», referida por Yunque, había sido adoptada por los revolucionarios de Asturias en 1934 para representar la unión de los proletarios de distintas facciones comunistas y anarquistas, lo que a su vez representaba una apropiación de las siglas presentes en las placas técnicas de las máquinas inglesas con las que trabajaban: U.H.P. es la unidad de medida de fuerza de los motores en caballos de fuerza, es decir, «Union Horse Power».

Más allá de esta incursión de Yunque, no cabe duda que fue Raúl González Tuñón el poeta argentino con mayor protagonismo en relación a la Guerra Civil Española. Primero, porque abandonó la «retaguardia» y fue parte de los «voluntarios con gafas» que estuvieron en España. Tuvo un paso en 1935, y más tarde volvió para representar a la Argentina en el Congreso de Escritores Antifascistas de 1937, invitado por Pablo Neruda, al mismo tiempo que trabajaba como corresponsal de guerra para La Nueva España, de Argentina. Segundo, por la cantidad y calidad de su producción poética y escrituraria en respuesta al conflicto. Publicó cuatro libros: La rosa blindada, La muerte en Madrid, Las 
puertas de fuego y 8 documentos de hoy entre 1936 y 1938. Y en último término, por su decisiva gravitación en el curso de la poesía social ya no únicamente en la Argentina, sino en lengua española.

Así lo recuerda Octavio Paz, otro de los poetas que estuvieron presentes en España:

Aún está viva en mi memoria la tarde en que lo conocí, en julio de 1937, en Madrid. Me lo presentó mi compatriota Siqueiros, en las vísperas del Congreso de Escritores para la Defensa de la Cultura. Él ya era un consagrado y me impresionó ese hombre suave y firme, que había escrito los más encendidos poemas sobre el pueblo español. Recuerdo haberlo oído leer "La libertaria", ese poema en el cual todos los oficios de España confluyen como en un rezo. Para esa generación escribir poesía combativa era escribir a la sombra de Raúl González Tuñón, es el Rubén Darío de la poesía social y no cometo una herejía si afirmo que España en el Corazón de Neruda y España aparta de mi este cáliz, de Vallejo no hubieran podido ser sin La Rosa blindada. Neruda lo reconoció con todas las letras y Vallejo hubiese hecho otro tanto si la muerte no lo hubiese sorprendido en París, en 1938. Desconozco su restante producción pero recuerdo que Luis Cernuda me dijo que era también un importante poeta lírico. Todo me aleja de aquellos años, pero en mi biblioteca guardo "La Rosa Blindada” porque es un hito. (Binns, Voluntarios 193)

Acierto o herejía de Paz, es indudable el peso de Tuñón dentro de aquella generación. Y, efectivamente, de su libro La rosa blindada. El libro sale a principios de 1936, antes del comienzo de la Guerra Civil. Es un homenaje, como el «U.H.P.» de Yunque, a los mineros y el 
pueblo de Asturias que protagonizaron el levantamiento de 1934. Sin embargo, es posible leer el prólogo de la primera edición como un verdadero pliego de intenciones al que buena parte de los grandes poetas hispanoamericanos comprometidos con la Republica durante la Guerra Civil suscribieron de hecho. Y también como un mapa de los cambios estéticos suscitados entre la vanguardia artística de la década de 1920, de la que Tuñón formó parte, y aquel nuevo escenario de fuerte compromiso ideológico con la causa de la revolución comunista. Tuñón parte, en primer término, de la imposibilidad de existencia de un arte neutro:

Si alguien me preguntara ¿qué es la poesía? no tendría más remedio que contestar: La poesía es la poesía, más el mundo, más el hombre, más el poeta, más la poesía. Si alguien me preguntara qué es un poema, contestaría: hasta el líder de la llamada "neutralidad" ha dicho que un poema que no contenga nada más que poesía no es un poema. He citado una frase de Valery.

Luego, acepta y reivindica la experiencia vanguardista:

Participé en los movimientos literarios de vanguardia y, sobre todo, el surrealismo contó con mi entusiasmo firme. Fue una manera de evadirse y volver a la multitud, de ganar la calle, de ejercitar valentía, de confesarse, de equivocarse, de reivindicar valores olvidados por la burguesía, de volver a imponer el gesto poético sobre lo prohibido, de ejercitar valentía, repito, para entrar luego de lleno -los que supimos hacerlo- en el drama del hombre y su esperanza, en los anhelos del hombre, en su destino "sobre la tierra". 
Por eso puedo decir ahora con Day Lewis que la revolución en la literatura comenzó pero sin una revolución social será fácil y sin trascendencia.

Este razonamiento de Lewis converge hacia la idea central del prólogo-manifiesto, que es la propuesta de una poesía revolucionaria o, al menos, la adopción de una actitud claramente antifascista por parte de los escritores:

Me parece que ahora hay que hacer poesía revolucionaria. Esto no quiere decir que los demás poetas, si son poetas, dejen de serlo al no sentir la necesidad de expresarse revolucionariamente, en el sentido de la propaganda. Lo que exigimos de ellos es una actitud antifascista concreta, porque el fascismo es el enemigo de la cultura y el arte, tanto como de la dignidad humana.

Tuñón avanza, a su vez, en un deslinde conceptual al interior de los poetas no revolucionarios:

Me parece también que hay que aclarar cuando se habla del llamado artepurismo. Hay dos grupos en esta tendencia: por un lado están los "puros", los deshumanizados, los nuevos retóricos, cuya obra, abundante en amorcillos, metáfora por la metáfora, discos conocidos, cursilería al revés, tragedias personales sin hondo valor humano, no interesa, no es arte; es subarte, apenas, y por otro lado aquellos que barajan en sus poemas elementos calientes, que hacen no una obra revolucionaria, pero una obra viva, llena de tierra y llanto, cubierta de raíces y de sangre. La posición de 
estos últimos será discutible desde el punto de vista nuestro, pero es humana y seria. Por otra parte los escritores que no sientan el tema revolucionario serán arrastrados a él tarde o temprano por imperativo de su conciencia misma de artistas.

Sobre el final, vuelve sobre el recurso experiencial y biográfico, para culminar, de acuerdo con Rimbaud, arrojando una eficaz consigna política:

Me gusta charlar en cualquier mesa -si delante de una copa de vino, mejorsobre temas, secretos, hallazgos, desdichas, felicidades, cosas de la poesía y de los poetas. Pero también me gusta estar listo para cuando haya que disparar sobre alguien con un poema o con lo que sea. Arthur Rimbaud fue la poesía, la gran aventura poética, pero en cierto momento gritó: “iCambiad la vida!”. (La rosa blindada 13-14)

Conciliar las experiencias vanguardistas con la necesidad de una poesía para las masas fue un apremiante desafío que marcó a buena parte de esta generación de poetas. La célebre frase de Rubén Darío, «Yo no escribí para las masas pero indefectiblemente tendré que llegar a ellas», se convierte en un imperativo que no acepta titubeos: «El poeta se dirige a la masa». Con esa frase abre Tuñón el segundo párrafo del prólogo a La rosa blindada.

A la tensión entre lo vanguardista y lo popular hay que añadirle, para el caso de los escritores que provenían de las ex-colonias españolas, otro elemento de peso. Se trataba, para ellos, de lidiar con el desprestigio en que había caído lo español como tema y como tradición tras las luchas de la independencia. Sobre todo en los ámbitos de la intelectualidad, y más aún entre aquellos que adscribían a la tradición liberal, que en 
Argentina representaba un variopinto espectro político que partía desde el radicalismo más conservador, atravesaba el socialismo hasta llegar al comunismo. Estos grupos eran los que apoyaban la causa de la Segunda República. Vale consignar, al respecto de los comunistas, cómo es que aparece España - casi como un tópico - en la interpretación historiográfica de Rodolfo Puiggrós. En una serie de conferencias que pronunció en 1939, reunidas al año siguiente en De la colonia a la revolución, libro publicado por la AIAPE, afirma:

En un mundo entrecruzado de relaciones capitalistas en desarrollo, donde el comercio y la navegación abrían círculos cada vez más amplios a la manufactura y al mercado mundial, España y sus colonias constituían una ínsula feudal sin otras perspectivas que el disgregamiento o la entrega. Las ideas de los políticos progresistas no encontraron en España el elemento receptivo, la base material indispensable para llevar adelante la revolución democrático-burguesa. Los parásitos feudales pudieron más que ellas, España continuó aferrada al siglo de la conquista, olvidando que los conquistadores hacía rato que habían muerto y que de sus tumbas sólo se alzaba la triste figura de don Quijote, cuyas empresas mil veces se estrellarían contra la cruda realidad de un mundo que la burguesía estaba forjando a su imagen y semejanza. (161)

Hay un salto meridiano de imagen entre esta España feudal, emblema del retraso, y la España de la Segunda República, repleta de anarquistas y comunistas, símbolo del futuro revolucionario, de un potente salto hacia adelante en lo social y político. Álvaro Yunque abre España, 1936 con un poema encaminado a esclarecer el equívoco. Se titula «España de 
Hoy». Se cita a continuación la tercera estrofa, pero puede consultarse completo en el Apéndice.

La de ayer, la España negra

Sus huestes insurrecciona,

Tira el fraile el crucifijo,

Coge la ametralladora,

Se arremanga la sotana

Y nos deja ver la cola,

(cavernícola con miedo,

con miedo y con hidrofobia),

sus pesetas fratricidas

gasta Ignacio de Loyola,

maúlla su escepticismo

de anciano Pío Baroja,

ríe el Borbón putrefacto

presintiendo una corona

y la Legión Extranjera

mata, incendia, estupra, roba...

España, la de hoy, cantarte

quiero con aire de copla. (España: 1936 sn)

Fue González Tuñón quien marcó este rumbo de «aire de copla». El primero en hurgar en el pasado hispánico, en la huella ya no solo formal, sino social y política. Y el primero, 
sobre todo, en explorar desde la poesía la relación entre ese pasado y el presente argentino, al vincularse afectivamente con las raíces hispánicas. La vuelta de tuerca de Tuñón es atractiva, porque no busca entroncarse con la España colonial, ni tampoco con la actual revolucionaria, sino que lo hace con la España obrera y campesina, la España de la persecución política y sindical de fines del siglo XIX y principios del XX. Aquella que, como Italia, nutrió a la Argentina de una enorme cantidad de ciudadanos - cerca de setecientos mil españoles emigraron a nuestro país entre 1880 y 1920-, y entre ellos, su abuelo Manuel Tuñón. Con un poema dedicado a este, «Recuerdo de Manuel Tuñón», comienza La rosa blindada. Se citan, a continuación, las primeras tres estrofas:

Recuerdo de Manuel Tuñón

Era un obrero del bronce aquel que en Mieres nació. Fuese a América con barba pero allá se la quitó.

Tenía yo nueve años cuando un día me llevó por entre los sobresaltos de una manifestación.

Así nací al socialismo, así comunista soy, 
así sería si viviera

mi abuelo Manuel Tuñón. (La rosa blindada sn)

El impacto poético y político de este poema de Tuñón es formidable. Resuelve, a un tiempo, el dilema de las dos Españas - la colonial y la actual revolucionaria - al escapar por la tangente hacia una realidad sensible, internacionalista en términos obreros, y también personal, vinculada a su historia familiar. El yo testimonial es una clave que coloca a Tuñón, en 1936, a la cabeza de las decisiones poéticas que reclamaba la hora. Mientras el poema que abre el libro de Yunque es un ejercicio retórico destinado a aclarar un equívoco, este poema de Tuñón es un contundente manifiesto en el plano estético y político. No le hace falta hablar del «aire de coplas». No hay nada que justificar. El nieto de un obrero socialista español puede rimar sin culpas a la revolución en España. La «España negra», aquella que Puiggrós define como «feudal», desaparece. Tuñón borra ese término de la ecuación del poema. Y esa supresión lo carga de una enorme potencia política. Se trata de una revancha de clase y también de una revancha familiar. España se lleva adentro. Está en la sangre obrera de Tuñón, como luego lo estará, por caso, en el corazón de Neruda.

Héctor Agosti advirtió contemporáneamente el valor de estos poemas de Tuñón, en un libro escrito desde una celda en la cárcel de Villa Devoto. El ensayo se titula «Variaciones sobre La rosa blindada» y fue incluido dentro de El hombre prisionero, que publicó en 1938 la Editorial Claridad. Se transcribe el inicio:

Bien hace Raúl González Tuñón al afirmar que la poesía revolucionaria no debe rebajarse al nivel de la masa, sino elevarse la masa a la altura de aquella. Nos habían acostumbrado —-más precisamente habíanse habituado- a pregonar lo contrario. Nos daban, así, un arte rebajado, 
escarnecido. Instrumento de propaganda, cuando más. Y mal instrumento, por añadidura. Olvidaban que la literatura no es propaganda, aunque pueda servir para ella. Y que la sirve sólo de manera indirecta, por el clima, el espíritu y el problema captados. Que la literatura sirve a la propaganda en el sentido elevado en que mueve las masas al amor por la revolución. Y que confiere de esta manera, al adjetivo servil, un contenido dignificante: servilismo en favor de la humanidad y del arte, nunca en desmedro de la una ni del otro.

Y unos párrafos más adelante, prosigue:

Y son los poetas auténticos quienes realizan ese ciclo que pudiera llamarse de retorno poético, una vez pasada la explosión superrealista. El antiacademismo - ifuera el ritmo, fuera el canto! - cumplió su faena, perdurable faena de volver al poeta su libertad poética. La travesura gramatical, la oscuridad metafórica — formulismos de técnica ostensible, a veces desprovistos de contenido medular - corren el riesgo de volverse, ellas también, "poesía pura", poesía deshumanizada que quiere decir poesía rebajada. La poesía nueva es un problema de técnica; pero es, ante todo, un problema de contenido. Véase a Rafael Alberti —el de Consignas, el de Un fantasma recorre Europa - mostrando cómo las formas más puras de la lírica española pueden colmarse de un contenido de esencialidad revolucionaria.

Y finalmente Agosti, este Agosti de 1938, inscribe Tuñón en ese derrotero en el que descolla Alberti. Un punto de partida para nada menos que una poesía de masas: 
Ahora, Raúl González Tuñón —-todavía no evadido definitivamente de un pasado que culmino en La calle del agujero en la media- enseña idéntico retorno en los romances iniciales de La rosa blindada. En la actividad poética de González Tuñón — siempre fervorosa - La rosa blindada señala un punto de partida. El punto de partida de una poesía de masas. Porque si el poeta no se rebaja al nivel de la masa, se dirige a la masa y aspira a ser comprendido por ella, y a ese fin encamina sus esfuerzos. La poesía revolucionaria debe ser, esencialmente, una poesía de masas. Por su contenido y por su significación formal y conceptual. Debe tener ritmo de canto, ritmo de himno, ritmo de pelea. No puede ser poesía hecha en clave - criptograma para el gozo de la feliz minoría de iniciados - he ahí, entonces, que el anuncio de esta nueva forma en la poética de González Tuñón este representado por los poemas de Asturias, dichos en tono y alma de romance, donde la emoción revolucionaria vibra en la sincera sencillez del verso. (El hombre prisionero 61-62)

Pero al mismo tiempo, Agosti encuentra en este «punto de partida» de Tuñón, La rosa blindada, la posibilidad de polemizar sobre la amenaza que representa la propaganda política en el contexto de una poesía revolucionaria de masas. Detecta desvíos que Tuñón realiza - una vez más, podría decirse- frente a las propias premisas que establece en el prólogo. Desvíos que tensan la frontera entre la poesía revolucionaria y la simple propaganda de consignas comunistas. Escribe Agosti en 1938: «Lamento que González Tuñón se haya dejado llevar en ocasiones por el deseo de introducir elementos extraños corchetes de tesis - en sus versos» (El hombre prisionero 62). 
Efectivamente, estos poemas iniciales no salvan a La rosa blindada de caer en los lugares comunes de la poesía social de neto corte propagandístico. Incluso en este sentido es precursora la obra de Tuñón. A modo ilustrativo se transcribe en el Apéndice el poema «La copla al servicio de la Revolución».

Agosti descubre en estos conflictos al interior de La rosa blindada la posibilidad de sentar posición frente a la poesía revolucionaria, sus aspiraciones, pero también sus límites. Argumento que puede figurarse, tal como luego lo amplió en Defensa del realismo, como una importante línea dentro del universo cultural del PCA:

La acción es el núcleo vital de la poesía revolucionaria. La acción y el optimismo. Si debiera buscar un paradigma espiritual del artista nuevo, pensaría en Cola Breugnon, pantagruélico y libre, que creaba cantando. Arte hecho carne, hecho sangre, hecho acción. Y acción vivificada de optimismo, de optimismo histórico. Porque no se admite una poesía revolucionaria desprovista del sentido optimista del mejoramiento histórico como fondo social de la creación poética. Y una poesía que no impulse a la acción no es poesía revolucionaria. En este sentido puede hablarse de la poesía política, o de la política de la poesía.

Agosti se apresura en distinguir poesía de propaganda, basado en textos clásicos del marxismo sobre el tema, haciendo hincapié en la cuestión del valor artístico:

No precisamos versos como afiches ni novelas como tesis. Eso podrá ser de excelente significación para la propaganda, pero carece en absoluto de valor artístico. Cuando hace algunos años dije cosas parecidas, los recién nacidos 
proletarizantes a todo trapo salieron al cruce. Nadie conocía, por ejemplo, el discurso de Lenín a los jóvenes comunistas, que publicamos por primera vez en 1929 y debimos reproducir más tarde por su perenne utilidad. Nadie conocía tampoco los textos de Marx y Engels, recientemente reunidos por Fréville, y pocos habíanse molestado en leer el libro de Plejanov y el breve y denso ensayo de Lunatcharsky. Ahora muchas opiniones se han modificado. Ahora ya no se cree, con tanta simpleza, que el arte revolucionario consista en un par de gritos a la sobra de un puño crispado.

En este polémico punto reaparece la poesía de Raúl González Tuñón:

Por ello opino que los poemas de González Tuñón - el único que, bien o mal, hace poesía revolucionaria en nuestro país - proporcionan la ocasión de debatir estos temas. Yo pienso que la posición práctica asumida por Tuñón se aproxima por mucho a la solución estética que debe darse a este problema de la poesía revolucionaria - fondo y forma - y pienso, también, que es una importante solución aproximada sobre la que debieran meditarse las necesarias conclusiones. La poesía nueva debe ser acción, impulso de las masas hacia la acción. Su política es ésa: política de la acción en favor de una humanidad libre y redimida. Que ante la avalancha del fascismo - avalancha de silencios y opresiones y destrucción de la cultura - la poesía no puede permanecer neutral, ahí está para probarlo la propia evolución del superrealismo, ahí está Bretón, ahí está Aragón. Poesía de la acción, necesitamos. Pera agradar a los preceptistas podríamos hablar de una "lírica 
épica". No creo en una resurrección del dadaísmo, en una vivificación del superrealismo.

Y finalmente, entabla un dialogo con la línea principal del Partido:

Algún día podrá decirse lo que esa inquieta búsqueda de la verdad poética significó en el caos angustiado de la trasguerra. Yo no creo que el problema de la poesía sea hoy cuestión de clanes literarios. "Realismo socialista" se ha dicho. Bueno: realismo socialista. Pero que sea una poesía de acción, de optimismo y de multitud. Una poesía que eleve a las masas hacia la dignidad de la poesía y de la libertad. (El hombre prisionero 63-64)

A esta intervención de Agosti en la batalla contra el arte de propaganda en las propias filas de los escritores y ensayistas comunistas, puede sumarse otro punto de máxima intensidad en la figura de Cesar Vallejo. Al igual que Tuñón, el poeta peruano reflejó su pensamiento en forma de ensayos sobre política y estética al tiempo que lo hizo en su poesía. Es decir, en una doble vía del pensamiento teórico y de puesta a punto en la escritura. Es interesante el contrapunto que ofrece la posición de Vallejo respecto de la de Tuñón, o, en todo caso, la perspectiva que entre ambos se conforma, pues ofrece un posible horizonte de intenciones para ir ubicando la poesía producida por Juan L. Ortiz en relación al conflicto de España.

Vallejo realizó tres visitas a la Unión Soviética a fines de la década del veinte. No viajó en misión oficial, ni en representación de un grupo o de un partido político, sino como un simple y curioso ciudadano, poeta por oficio. Al regreso del último de aquellos viajes, se instaló en Madrid y publicó sus crónicas bajo el título de Rusia 1931, reflexiones al pie del Kremlin. El libro, que comporta la novedad de ser el primer reporte de magnitud sobre la 
situación de Rusia bajo la revolución escrito originalmente en lengua española, se convirtió en un éxito editorial. Era la España de la Segunda República, y el interés por aquella experiencia estaba a la orden del día. Ese mismo año, Vallejo publicó El tungsteno, una novela breve en sintonía, precisamente, con el realismo socialista.

No obstante las buenas condiciones del período para la recepción de esa veta de su escritura, varias obras suyas quedaron en el tintero. Entre ellas se cuentan Rusia ante el segundo plan quinquenal; dos obras de teatro, Lock-out y Moscú contra Moscú; y los ensayos de El arte y la revolución. Este último libro, que Vallejo ya tenía listo en 1931 y que fue reelaborando hasta su publicación en 1934, resulta de mucho interés para la materia de esta tesis. Se trata de reflexiones, anécdotas e impresiones sobre la relación que se establece, precisamente, entre arte y revolución, un asunto central para la literatura en la primera mitad del siglo XX. A pesar del tono y la calidad despareja de sus ensayos, Vallejo logra transmitir allí una visión original, con muchos matices, de la manera en que es posible pensar una literatura de izquierda que no reduzca el socialismo a los temas ni a la técnica del poema.

Se puede especular que la falta de interés en la publicación del libro haya derivado del modo corrosivo con que allí se retrata a los intelectuales revolucionarios fanáticos del arte al servicio de la causa social (Vallejo, El arte y la revolución 36). Enfrentándose a estos, el poeta afirma la existencia de una poesía socialista por fuera de las simplificaciones estéticas del realismo en su vertiente de denuncia, entendiéndola como la manifestación de una sensibilidad orgánica y tácitamente socialista, sin ver en ello una disminución del carácter social y revolucionario de la misma, sino por el contrario, un enriquecimiento.

Para comenzar a delinear o poblar ese posible horizonte de intenciones que resulta de contraponer la visión de Vallejo a la de Tuñón, puede partirse de una secuencia extraída de 
Rusia 1931, reflexiones al pie del Kremlin. Sucede en Moscú, en algunos sus viajes entre 1928 y 1930. No aparece precisada la fecha. Vallejo relata, en forma de crónica, el día entero de un obrero albañil. El poeta decidió acompañarlo durante una jornada y así tener una impresión a escala doméstica de la revolución bolchevique. Como no manejaba el idioma, contrató a una intérprete. Esta tarea recayó en manos de una sobreviviente de la antigua burguesía zarista, previsiblemente reaccionaria al régimen. A las siete y media de la mañana, acompañado por ella, Vallejo se presenta — siempre según su relato- en la vivienda del albañil. La describe como una pieza estrecha dentro de una casona reacondicionada como pensión. De allí en más, pasan el resto del día juntos. Las actividades del obrero, más allá de las ocho horas de trabajo, parecen no tener fin. Una reunión en el club obrero lo entretiene hasta la noche, y luego, cuando se encuentran en la cena, le anuncia a Vallejo sus intenciones de asistir al teatro. Siguiendo el plan inicial, el poeta y su intérprete lo acompañan. La pieza teatral que presencian tiene por protagonista a un obrero. En la primera escena se lo muestra trabajando, lleno de vigor. En la segunda, en cambio, el tono es otro. Se relata el momento en que regresa a su hogar, donde efectivamente va a acontecer la tragedia. Afectado por el panorama que observa al entrar —su hijo de doce años duerme solo, en la habitación oscura y vacía, pues su mujer trabaja en ese turno-, el obrero no logra conciliar el sueño. Se debate, piensa y sufre porque no puede adaptarse a la idea de que el hogar ya no esté en su casa sino afuera, en las fábricas, en los comités, en las cooperativas:

Culmina en un arranque desesperado. Toma un frasco y va a apurar su contenido[...] El suicidio en la sociedad soviética es uno de los tantos residuos intermitentes y reacios de la psicología reaccionaria. Reaparece súbitamente 
y a mansalva. Pero el obrero vacila. Lucha todavía. Es la hora del sudor de sangre y del "Aparta de mí este cáliz". Al levantar el frasco, una mano se lo impide repentinamente. Es la mano del hijo, que no dormía. El movimiento de éste es de un sentimiento social trascendental. (Rusia en 1931, reflexiones al pie del kremlin 111)

Seis años más tarde, Vallejo publicó su último libro de poemas en el contexto de la Guerra Civil Española . Su título, ya célebre, fue España, aparta de mí este cáliz.

Frente a la anécdota, una dialéctica asombrosa convierte a España en el hijo, encarnando el sentimiento social trascendente que tiende su mano, y a él, al poeta sensible, lleno de residuos intermitentes y reacios, en el obrero rescatado por aquella. De esta manera, en el horizonte aparece la revolución, y al lado suyo, alimentando y siendo alimentada, la propia sensibilidad del poeta.

Puede leerse ya en los primeros versos del poema que abre España, aparta de mí este cáliz, «Himno a los voluntarios de la república»:

Himno a los voluntarios de la república

Voluntario de España, miliciano de huesos fidedignos, cuando marcha a morir tu corazón, cuando marcha a matar con su agonía mundial, no sé verdaderamente qué hacer, dónde ponerme; corro, escribo, aplaudo, Iloro, atisbo, destrozo, apagan, digo a mi pecho que acabe, al bien, que venga, 
y quiero desgraciarme ... (127)

España, aparta de mí este cáliz fue un libro urgente, no cabe duda, pero fue un libro urgente de una línea poética madura. No se resintió ni se tipificó con la incorporación de la veta política y revolucionaria; logró transmitir esa lucha, esa tragedia, como una experiencia. Los poemas toman su forma del diálogo entre revolución y sensibilidad, desechando los moldes preestablecidos. En Vallejo, el himno no se agota en el canto a las batallas ganadas o perdidas por los héroes, sino que es, sobre todo, el relato de una sensibilidad, la del poeta, que es la medida de los sentimientos nacidos a la sombra de la Guerra Civil.

A este enfoque refiere el relato que vuelca Raúl González Tuñón en un pasaje de su crónica sobre Vallejo, publicada en La literatura resplandeciente: «Diremos a quienes pretenden tomar a Vallejo como bandera, paradigma de combatiente, que se equivocan. Estaba desorientado, vacilante, amargado, hasta que el resplandor de España en armas lo iluminó. Este y otros hechos surgen de mis recuerdos personales» (63). Tuñón reviste de un signo negativo el carácter vacilante de Vallejo, suficiente para apartarlo del paradigma de poeta combatiente.

Hay, como es notorio, una brecha. Consignarla es acercarse al corazón del debate dentro de las estéticas revolucionarias en poesía. No se trata de valorarlo en términos de un enfrentamiento personal, ni mucho menos, sino en el de dos modos de concebir la poesía revolucionaria, que pujan por establecerse como modelos.

Como ya se ha dicho, en el tránsito que va de las vanguardias de la década del veinte a esta situación politizada de la década del treinta — que se va a extender hasta mediados de los cuarenta-, los que se conocen hoy como los principales poetas sociales de América 
Latina realizan un repliegue hacia las formas tradicionales de la poesía. Podría objetarse, y con razón, que en poetas como Tuñón y Neruda abunda la utilización del metro fijo, incluso de ciertos esquemas rítmicos tradicionales en poemas anteriores a este momento. Lo que se intenta, en todo caso, no es negar esa realidad sino poner en relieve la brusquedad y determinación del cambio operado, que será consciente y afectará al conjunto de sus obras. La correcta transmisión del mensaje revolucionario parece encontrar - a partir de mediados de la década de 1930- un límite en las formas vanguardistas que estos cultivaban. Tampoco funcionaba junto a los temas que poblaban sus poemas. Lo dice de manera clara Pablo Neruda (1947) en esta prolija estrofa de endecasílabos rimados, de su poema «Nuevo canto a Stalingrado»: «Yo escribí sobre el tiempo y sobre el agua,/ describí el luto y su metal morado,/yo escribí sobre el cielo y la manzana, ahora escribo sobre Stalingrado» (Tercera residencia 77$)$.

Marcos Golfarb (1985), en un estudio sobre la relación de Neruda con el comunismo, afirma: «Desde la experiencia de la Guerra Civil Española , su proyección poética se aferra con palabras que proclaman y postulan el dolor del oprimido. No era posible para Neruda escribir sobre los volcanes de su país cuando en ese mismo instante la sangre de los niños “corría simplemente" por los campos de batalla» (Goldfarb 103).

Dos libros de Juan L. Ortiz, El alba sube (1937) y El ángel inclinado (1938), representan su reacción inmediata -en términos temporales - al suceso de la Guerra Civil Española. Del mismo modo que en Vallejo, la poesía de Ortiz no se resiente ni se enajena al incorporar lo político, lo revolucionario, ausente hasta entonces como tema en su única obra publicada, El agua y la noche (1933). En el discurrir de los poemas puede notarse cómo el drama va trastocando la sensibilidad, interfiriendo la percepción del paisaje. María Teresa Gramuglio (2004) explica el fenómeno de la siguiente manera: 
[la política] Se inscribe en la forma, configurando en los poemas una estructura recurrente que se despliega en tres momentos, o movimientos: un primer movimiento, el momento de dicha, el estado de plenitud y sobre todo de armonía que produce la contemplación del paisaje; en el segundo movimiento, generalmente introducido por un giro adversativo (el pero que inicia tantas estrofas), la irrupción de algo que hiere esa armonía: el escándalo de la desigualdad, la crueldad de la pobreza, el horror de la guerra, el desamparo de las criaturas; en el tercero, esa tensión, a veces generadora de culpas, convoca una visión que se modula en los tonos de la profecía o del anhelo: la utopía de un futuro radiante donde serían abolidas todas las divisiones y la dicha podría ser compartida por todos los hombres. (Gramuglio 64)

Por el sencillo hecho de que no se propone agotar el impacto de la política sobre la forma de los poemas de Ortiz, sino servir de modelo para contrastarlo con las propuestas dominantes en ese terreno y así destacar su singularidad, esta esquematización de Gramuglio tiene un alcance parcial. Más de la mitad de los poemas políticos de los dos libros referidos, El alba sube y El ángel inclinado, están por fuera de esa estructura recurrente. Y es precisamente en estos poemas que están por fuera donde la resolución de esta tensión alcanza su grado máximo de singularidad, al desprenderse del obligado final optimista, con esa utopía de un futuro radiante que la estructura descripta por Gramuglio supone. Porque en definitiva, a nivel de función, ese final es equiparable a los finales siempre optimistas y redentores de los poemas revolucionarios vinculados directamente a la propaganda comunista. Ortiz, por otra parte, es absolutamente consiente de su posición, de su lugar y 
de lo que propone. Esa conciencia se deja ver —-tal como lo señaló Agosti en su ensayocon toda claridad en «Sí, yo sé», de El alba sube:

Sí, yo sé

Sí, yo sé que un hilo de flauta

es despreciable para vosotros.

Que las canciones de marcha son las a vosotros debidas, ahora en que es necesario ir, bajo ráfagas de fuego, acaso, a ayudar a nacer el mundo nuestro y vuestro.

Pero es tan sereno y delicado este crepúsculo

de fines de Agosto

que pienso en una frente ilusionada de adolescente esparciendo una frágil fiebre de sueños secretos y fragantes.

La frente de los adolescentes, qué adorable! qué adorable!

La misma palidez ilusionada de este cielo.

Y estos tímidos brotes, son sueños aflorados?

Hay un tierno azoramiento de sueños evaporados, y muy tenue, que da un valor ya floral a las casitas blancas, una suavidad de rosas a la arena de la calle... (El alba sube 56)

El poema está fechado en 1936, y el «vosotros» hace referencia a las milicias de la lucha republicana de la Guerra Civil Española , que recién comenzaba. El motivo, que aparece ya definido en los cuatro primeros versos, termina de comprenderse si se vuelve sobre el 
pedido de Raúl González Tuñón en el prólogo-manifiesto a La rosa blindada, de darle al poema «ritmo de marcha, condición de que pueda ser cantado» (13). Ortiz está pensando en su poesía un problema que años después señaló David Viñas en la obra de Tuñón. Desde mediados de la década del treinta, según el crítico, se produce en la poesía de Tuñón un deslinde de territorios, los viejos gustos del poeta no logran convivir con la visión revolucionaria, que genera dentro de su obra un espacio poético propio cercano en su forma a la prosodia tradicional de la poesía didáctica y heroica en castellano (Viñas, Literatura argentina y política. Tomo II. De Lugones a Walsh). Ortiz parece advertir que en el cambio de calibre de las intenciones se pierde buena parte del universo sensible del poeta. Al mismo tiempo que reconoce que ese cambio tiene la función histórica y concreta de apoyar una lucha de la que depende la posibilidad de existencia de la poesía, tal cual lo dice en el quinto verso, con eso de «ayudar a nacer el mundo nuestro y vuestro». En Ortiz se da todo junto. Conjuga la advertencia con la urgencia revolucionaria. Y si no hay deslinde de territorios, es porque precisamente su poesía se nutre del diálogo, se establece, o busca establecerse, como la huella sensible del choque.

Al igual que Vallejo, lo poético no se resiente con el ingreso de lo político sino más bien lo contrario, se enriquece, gana en matices y en tensión. Lo político es un horizonte que enriquece el poema porque nunca aparece sólo. Ortiz desarrolla su reflexión en la poesía: instaura al poema, no al prólogo o al ensayo, como el lugar donde la poesía se piensa a sí misma, donde piensa su función, donde dialogan sus territorios y se deslizan sus aspiraciones. Pero no lo hace en cualquier momento, lo hace precisamente cuando la misma está siendo llamada de manera drástica al combate. Una poesía reflexiva en medio de lo que Halperin Donghi (2004) llamó «la tormenta del mundo» (La argentina y la tormenta del mundo). Hay un ansia de compensación en el plan poético de Ortiz. En el sentido en que 
conoce y ayuda a difundir los poemas de combate, pero adjudica, a su vez, a la poesía, la función de mantener a resguardo de las inclemencias aquello por lo que se lucha. Es lo les dice a los combatientes republicanos en un pasaje del poema «No podéis, no, prestar atención» de El ángel inclinado: «Sujetar, no cortar, las alas del alma/ aunque éstas sean finas y sensibles/ para que los vuelos futuros sean más altos/ Es ésta, hermanos míos, "una prueba de alas"»(Obra Completa 236-37).

La notación del paisaje fluvial entrerriano, e incluso de un cierto paisaje de cultura siguiendo siempre el concepto que vierte Pedro Salinas (2005) en su libro La poesía de Rubén Darío - vinculado al modernismo y al simbolismo, son los órdenes que se oponen al drama. En esa tensión desmesurada que se establece entre las «ráfagas de fuego» y el «tierno azoramiento de sueños evaporados», en esa imposibilidad de dejar de ser lo que se es, se vislumbra el tenor de la tragedia. Esto representa, desde el punto de vista estrictamente literario, una resolución más entre otras posibles. Lo que es relevante es el desviamiento que acontece en el nivel de la función: si la poesía de Ortiz comparte con la poesía convencionalmente revolucionaria la ideología, el tema y las intenciones, se aleja en cambio de su función didáctica. Se aleja, incluso, de aquello que reclama Agosti en 1937, la finalidad de apuntalar directamente la lucha por un mundo mejor. Pero ¿hacia dónde se dirige?

Se ha hecho referencia a un libro de ensayos de Vallejo, de suerte esquiva, llamado EI arte y la revolución. Allí, el poeta peruano distingue entre el arte de propaganda y agitación, que llama bolchevique, y el arte socialista:

El poeta socialista no reduce su socialismo a los temas ni a la técnica del poema. No lo reduce a introducir palabras a la moda sobre economía, 
dialéctica o derecho marxista, a movilizar ideas y requisitorias políticas de factura u origen comunista, ni a adjetivar los hechos del espíritu y de la naturaleza, con epítetos tomados de la revolución proletaria. El poeta socialista supone, de preferencia, una sensibilidad orgánica y tácitamente socialista. Sólo un hombre temperamentalmente socialista, aquel cuya conducta pública y privada, cuya manera de ver una estrella, de comprender la rotación de un carro, de sentir un dolor, de hacer una operación aritmética, de levantar una piedra, de guardar silencio o de ajustar una amistad, son orgánicamente socialistas, sólo ese hombre puede crear un poema auténticamente socialista. Sólo ése creará un poema socialista, en el que la preocupación esencial no radica precisamente en servir a un interés de partido o a una contingencia clasista de la historia, sino en el que vive una vida personal y cotidianamente socialista (digo personal y no individual).

Al igual que Agostí, Vallejo busca deslindar arte de propaganda:

En el poeta socialista, el poema no es, pues, un trance espectacular, provocado a voluntad y al servicio preconcebido de un credo o propaganda política, sino que es una función natural y simplemente humana de la sensibilidad. El poeta socialista no ha de ser tal únicamente en el momento de escribir un poema, sino en todos sus actos, grandes y pequeños, internos y externos, conscientes y subconscientes y hasta cuando duerme y cuando se equivoca y cuando se traiciona voluntaria o involuntariamente y cuando se rectifica y cuando fracasa. (El arte y la revolución 28-29) 
Y avanzando sobre el terreno del lenguaje y de sus reglas, escribe Vallejo en ese libro de 1934:

La gramática, como norma colectiva en poesía, carece de razón de ser. Cada poeta forja su gramática personal e intransferible, su sintaxis, su ortografía, su analogía, su prosodia, su semántica. Le basta no salir de los fueros básicos del idioma. El poeta puede hasta cambiar, en cierto modo, la estructura literal y fonética de una misma palabra, según los casos. Y esto, en vez de restringir el alcance socialista y universal de la poesía, como pudiera creerse, lo dilata al infinito. Sabido es que cuanto más personal (repito, no digo individual) es la sensibilidad del artista, su obra es más universal y colectiva. (El arte y la revolución 29)

Desplegar la poesía de Ortiz en este paisaje de intenciones que se fue constituyendo tiene en principio dos consecuencias: la primera, y fundamental, es que ayuda a comprender de un modo concreto las relaciones que vinculan en su interior al arte, la revolución y la sensibilidad. En este sentido, Vallejo nos devuelve un Ortiz potente, nos permite situar mejor el desafío que supone la construcción de una obra orgánicamente socialista, con un modo, una estructura y una fonética personalísima. Por otro lado, a nivel de la historia de la poesía, permite leerlo como poeta social por fuera de las coordenadas de ese «poeta social» por antonomasia de la literatura argentina que es Raúl González Tuñón. No se intenta decir con esto que Tuñón no esté en el centro de la poesía social argentina, cosa indiscutible desde cualquier punto de vista, sino que su obra recorre uno de los horizontes, mientras que la de Ortiz recorre otro. La poesía que escriben como respuesta al conflicto español 
refleja con mucha precisión la plena conciencia, por parte de ambos, de las herramientas y sobre todo del lugar que ocupaban sus figuras y sus producciones poéticas.

\section{La respuesta de Ortiz}

La hipótesis de que la poesía de Ortiz, su respuesta, brinda una resolución sugestiva a la siempre tensa relación entre poesía y política en el período 1936-1946, impone un análisis detallado de las características de su obra y, de modo progresivo, del modo en que el poeta trabajó esa materia para implicarla de manera efectiva y original en el terreno de la poesía social. Para ello, nada mejor que empezar por los leitmotiv que la acompañan, precisamente, desde sus comienzos y, en buena medida, la definen: «una poesía del río», «una poesía musical».

\section{Una poesía del río}

El río, en tanto tema, es decir, en tanto materia de la experiencia poética, ha sido quizás el que mayor atención le demandó a Ortiz. Es previsible que a lo largo de años de escritura, haya este ensayado diversas resoluciones. Lo que destaca, frente al panorama, es una sorprendente organicidad en sus búsquedas. Como sí Ortiz estuviera acechando, una y otra vez, a lo largo del tiempo, un único territorio.

Sin embargo, es factible disponer en diversas series sus escrituras del río, siguiendo un orden en relación al simbolismo. Un primer grupo de poemas cae o se ordena bajo el manto de una sorprendente decisión inicial, que nace con su primer libro, El agua y la noche, de 
1933: no nombrar jamás el río al que se está refiriendo. Esta decisión estética dota a su poesía de una inmediata novedad. El río es el río. Ese menoscabo de la ambición toponímica tiene, en su reverso, la efectiva consignación de los matices que ha adquieren las orillas, las islas, la corriente. Tal como puede leerse, entre otros, en el poema «El río tiene esta mañana», de El ángel inclinado, su tercer libro, de 1938, escrito mientras vivía en Gualeguay. Se citan las dos últimas estrofas:

El río tiene esta mañana

Una mujer que va hacia una canoa.

Hombres del lado opuesto que cargan la suya.

Los gestos de los hombres y el paso de la mujer

y el canto de los pájaros se acuerdan

con el agua y el cielo en un secreto ritmo.

Un momento de olvido musical, un momento.

Un momento de olvido para nosotros, claro. (Obra Completa 232)

Cuando se visita Gualeguay, y tropezando un poco con la ignorancia de los actuales vecinos se llega al kiosco en que devino la casa del poeta, se atraviesa el parque que queda justo enfrente, se cruza el canal y se caminan otros pocos metros, cuando se tiene delante el río Gualeguay, es inevitable que el lector de Ortiz tenga la impresión de estar ante aquello que, sin conocer, ya conocía.

El hecho de que Ortiz no mencione, en los poemas de sus primeros cuatro libros, y en otros tanto posteriores, al río Gualeguay ni a sus arroyos afluentes, no implica que ese río 
no sea el soporte de esas experiencias fluviales. La eficacia radica en un delicado equilibrio entre la precisión de un ojo y un oído agudo y entrenado en captar el detalle, la nota esencial del momento del río, y el hecho de no nombrarlo.

La índole de las sucesivas observaciones fluviales que registra Ortiz develan un contacto atento: están los colores, los matices, la cualidad de los sonidos, y todo esto en combinación con las estaciones del año, incluso con los diferentes horarios del día y hasta con las temperaturas. A tal extremo dona su experiencia de la contemplación, que sus versos se tornan objetivos a fuerza de quebrar las convenciones: «Río rosado aún en la noche», titula a uno de sus poemas de El alba sube; «Invierno. Tarde tibia» a otro, que comienza con la siguiente estrofa: «Invierno. Tarde tibia/Como en una dicha diamantina todo./ Aéreos, casi, la hierba y el agua.» (Obra Completa 239).

Lo que no implica que Ortiz haya cantado al río Gualeguay tal cual era. En toda operación de escritura hay selección, recorte, transformación. Podría hacerse una lista de elementos del Gualeguay que no están en su poesía. Sin ir más lejos, las barcazas que trasportan hacienda con animales desde el puerto de Puerto Ruiz hacia el Paraná. No figura en su obra ese aspecto del río, el Gualeguay como vía de salida del ganado y los cereales de esa región entrerriana. Algo existente, con una gravitación cotidiana, desde mediados del siglo XIX en adelante, llegando incluso a modificar físicamente del río, con el canal dragado para ganar profundidad en los cuarenta kilómetros que separan a Puerto Ruiz de la desembocadura del Gualeguay en el Paraná.

Pero el razonamiento, o la mirada, se vuelve atractiva cuando se la invierte: no todo el río Gualeguay aparece en estos poemas de Ortiz, es cierto, pero ante el río, inmerso en su contemplación, se tiene la impresión de estar ante una totalidad orticiana. 
Esta serie de poemas sobre el río donde opera la sustracción del nombre es la que mayor trascendencia ha tenido dentro de su obra. La razón es compleja, pero interesa detenerse en un aspecto: la ausencia como principio motor. Ausencia que figura en el célebre «Fui al río», de El ángel inclinado. Se transcribe la primera estrofa:

Fui al río

Fui al río, y lo sentía cerca de mí, enfrente de mí. Las ramas tenían voces que no llegaban hasta mí. La corriente decía cosas que no entendía. Me angustiaba casi. Quería comprenderlo, sentir qué decía el cielo vago y pálido en él con sus primeras sílabas alargadas, pero no podía. (Obra Completa 229)

¿Qué río? Podría preguntarse. El contexto nunca se repone y el lector accede, por la gravitación encantadora de sucesivas veladuras, al corazón de la experiencia poética.

Paralelamente, mientras estos poemas siguen su curso, empiezan a aparecer algunos ríos mencionados hacia las décadas de 1940 y —ya por fuera del período de estudio- a principios de 1950. Dos ejemplos, el río Paraná en «Los mundos unidos (El hospital Palma)», que fue publicado en mayo de 1942, en el no 14 de la revista Nueva Gaceta dirigida por 
Héctor P. Agosti, y el río Gualeguay en el poema «Las Colinas». A los que podrían agregarse otros poemas «Gualeguay» y «La casa de los pájaros» (este último refiere a la casa que habitó en 1941, como punto intermedio en su mudanza de Gualeguay a Paraná), donde también aparece el río Gualeguay. Aunque claro, son piezas que decididamente no cuadran con lo expuesto hasta aquí. Conforman un segundo grupo separado del anterior, una serie excepcional por tres motivos. Primero, se trata de poemas donde la finalidad aparece en la superficie: la celebración civil, el tema autobiográfico, la militancia por la igualdad. Segundo: un uso particular del topónimo. Puesto a nombrar las cosas que lo rodean, se tiene la impresión que Ortiz no puede detenerse: «camino hacia "La Carmencita"», «el bajo», «la "escuela vieja"» «la chacra en que estaba Don Juan», «las vecindades del "Prado"», «el "Barrio de las ranas"», «la pieza de Agustín», "el arroyito de la crecida», «un banco perdido en la parte este del Parque», son algunas de las muchas referencias que aparecen desperdigadas en estos poemas.

Ortiz emplea en esta segunda serie una escala diminuta de nombres que anulan todo vestigio de fomento de la región. Las señas carecen, notoriamente, de las cualidades mínimas para tolerar esa mirada, orientándose más bien hacia un lector-cómplice de la propia zona. Una operación de veladura no marcada esta vez por la ausencia del nombre sino por su escala mínima. Y, para finalizar con el tercer motivo que determina la serie: se trata de poemas donde asoma la acción. Aquel título de Salvadora Medina Onrubia (1914) cuando recibe al joven Ortiz en Buenos Aires, «A caballo, a pie, a nado, en bote», encuentra continuidad, se despliega en la propia obra del poeta. Solo que, como se verá a continuación, el recorrido es inverso, es él quien recibe las visitas de los ávidos porteños en «Gualeguay»: 
[...] A Carlos, el tercer Carlos, lo traía el estío, más blanco aún de/ gran ciudad, con los últimos "frissons" y una sonrisa afilada para todas las "arrugas"... Venía con él el Negro Luis, impaciente de tropos y de faldas, pero con / sed de agua sola...

-Oh, detallábamos juntos, sobre el "biciclo", muchas fugaces dulzuras / del camino, y en la canoa "celosa", por la isla, muchas intimidades del reflejo. (Obra Completa 467)

Existe, para concluir esta clasificación ad hoc de los poemas del río, una última serie a la que cabe prestarle una atención especial aunque, se advierte, su desarrollo es posterior al período de interés. Comparte, con la anterior, el atributo de la nominalidad extremada, y también, ciertamente, el de la intencionalidad. Solo que esta vez, el centro de la atención estará puesto en el río. En realidad casi que no llega a serie, pues solo la conforman dos poemas: «Al Paraná» y «El Gualeguay», piezas que Juan L. Ortiz comienza a escribir a partir de la década de 1950, y se publican en libro entre 1970 y 1971, en la edición de En el aura del sauce, por la Editorial Biblioteca de la Vigil, en Rosario.

Estos poemas a los ríos Gualeguay y Paraná comparten una clave que, a falta de una mejor expresión, podría denominarse «histórica». Aún en su delicado desenvolvimiento, dicha clave perturba la asimilación del paisaje en tiempo presente e impone, por su propia impronta, otro ritmo, otro tiempo, otra duración a la mirada que el poeta extiende sobre el río. Ciertamente, será en «El Gualeguay», el poema-libro, donde esto adquiera una dimensión verdaderamente colosal. Si el río ha sido el centro de la vida de los hombres, de 
los animales y de las plantas de la región desde los tiempos remotos, para contarlos y mantener viva la memoria, nada mejor, parece decir Ortiz, que contarlo.

En este sentido, "El Gualeguay», en mayor medida que "Al Paraná», se presenta como uno de los principales poemas civiles de Ortiz. Incluso en términos de militancia. Luego de la Revolución de Junio de 1943, bajo el peronismo histórico y tras la caída de Perón en 1955, el tópico de «los deberes de la inteligencia», acuñado por Aníbal Ponce en la década de 1930, fue, como se ha indicado, moneda corriente entre la sociabilidad comunista a la que perteneció el poeta. En otro pasaje del ya citado artículo "Mayo y la inteligencia argentina», publicado en Ortiz (1942) escribió: «En este proceso de ahondamiento de nuestra individualidad, nuestra conciencia histórica, nuestra sensibilidad histórica, pueden jugar jugarán- un papel de importancia. El sentimiento de nuestra tradición revolucionaria y de los ideales que nos dieron vida como nación, está estrechamente ligado a la conquista de nuestra alma individual y colectiva y al arte, por lo tanto, que pueda surgir de ella» (J. L. Ortiz, El Litoral sn).

Pero «El Gualeguay», además de un poema-libro es un poema-problema. Hace unos años, Sergio Delgado (2005) tuvo la atinada idea de editarlo suelto, en un único volumen, respondiendo al proyecto original de Ortiz. El resultado fueron 49 páginas de prólogo, 120 páginas de notas y, en el medio, las 95 páginas del poema con sus versos plagados de asteriscos (J. L. Ortiz, El Gualeguay). El problema ya lo había planteado agudamente Carlos Mastronardi en una carta que le enviara al propio Ortiz a mediados de la década del 1950, a propósito de otro poema, «Gualeguay»: «Las personas y los hechos que finamente convocas vienen a ser, ya reunidos, como un secreto carnet del alma, como una vasta ternura retrospectiva que no aspira a lograr autonomía "exterior". Pienso en el lector -no de 
nuestro medio y nuestra época-y me pregunto si los nombres que les propones son canjeables para él» (Veiravé 163)

Efectivamente, el esfuerzo de reconstrucción que requiere un poema como «EI Gualeguay» para «canjear» cada una de las referencias históricas y geográficas difícilmente se condiga con aquellas otras coordenadas que son, por decirlo de alguna manera, distintivas de la poesía de Ortiz: el ritmo, la musicalidad, la necesaria ligereza. Incluso, en el aspecto visual del poema -intervenido por la edición - la contradicción entre la sutileza de los caracteres pequeñísimos combinados con el generoso interlineado y la llamativa presencia de asteriscos y notas.

\section{Una poesía musical}

La musicalidad de la poesía de Ortiz, su tránsito, se articula en diversos niveles del texto, donde nada parece quedar al azar: desde la intencional reiteración de una letra, el uso de los diminutivos, hasta la predilección por las acentuaciones esdrújulas o la elección de un determinado léxico en base a su sonoridad. Su búsqueda se realiza en el territorio del verso libre sin rima, es decir, desechando desde el vamos las herramientas tradicionales de la poesía para plasmar una intención musical.

En este sentido es el ritmo, nacido de una intención dialéctica que está en la base de su poética, el instrumento central de la musicalidad de Ortiz. Y ese ritmo puede rastrearse como huella de un diálogo. ¿Pero de qué clase de diálogo? Evidentemente, por el tipo de construcciones y por los signos que deja impresos en el poema, no se trata de un diálogo asertivo, sino de una construcción progresiva que posterga y suspende las conclusiones. Este modo se manifiesta en las interrogaciones, ya sean cerradas o abiertas (un solo signo 
cerrando al final del último verso); también en los puntos suspensivos, y en la reiteración de una palabra en distintos contextos (asertivo/interrogativo) para que resuenen otros sonidos y sentidos.

A su vez, la música ingresa en la poesía de Ortiz como tema. Sin abandonar su sentido originario, los conceptos de armonía y de silencio se vuelven claves de su mundo poético. La relación entre música y poesía en la obra de Ortiz es compleja, consciente, y opera en todos los niveles al mismo tiempo.

Las palabras con que el boedista Carlos Serfaty define su lenguaje en la revista Unidad en 1937, al hablar de ese «tono que hace diáfanas las palabras y nos envía el sonido de cada sílaba, milagrosamente atenuado» (Unidad 16), remiten de forma directa a los ejes de la musicalidad, de esa exploración peculiar de Ortiz. Pero fue Héctor Agosti quien mejor comprendió, de manera contemporánea a la salida de los libros, la clave que proponía en este aspecto la poesía social de Ortiz. El pasaje ya se ha citado en el cierre del capítulo primero, pero vale la pena reiterarlo:

Aludo repetidamente a este lenguaje de Ortiz porque su valor procede directamente de él mismo, de su desnudez no empañada por ninguna trampa de oficio. No hay en Ortiz ni los viejos juegos retóricos ni el brillante oropel técnico, frecuentes ocultaciones de la flacura del pensamiento. Su lenguaje es dolorosamente sobrio y severo. Sus metáforas aléjanse del fuego del artificio. En el lento descarnar de sus versos, hasta dejarlos en ese cuerpo delgado y macizo, Ortiz marcha hacia la obtención de un lenguaje depurado, delicadamente conmovedor. No es la suya poesía para recitativos. No es el 
verso para cantar, que alguna vez nos anunciara Raúl González Tuñón. Ya lo sabe el poeta, antes que se lo digamos:

Sí, yo sé que un hilo de flauta es despreciable para vosotros.

Que las canciones de marcha son las a vosotros debidas ahora que es necesario ir, bajo ráfagas de fuego, acaso a ayudar a nacer el mundo nuestro y vuestro, confiesa en El alba sube... Ortiz es un lírico de temperamento casi elegíaco. Su lirismo, sin embargo, no es evasión. Siente profundamente el misterio de la noche y de la mujer, el misterio doble que motiva uno de los poemas más bellamente concebidos de El alba sube..., su segundo volumen (1937). Dicho misterio, empero, no le impide preocuparse con dignidad de otros misterios que atañen directamente a la condición humana. (112-113)

Ahora bien ¿a qué tradición responde ese «hilo de flauta» con que Ortiz define su voz? ¿En qué línea puede inscribirse su poesía, y, más concretamente, su poesía social? Hay un modelo con el que es factible emparentarlo $-y$ con el cual Ortiz entra en contacto en su estadía porteña a partir de 1914- que suma el imaginario anarquista y socialista y el ascendente modernista en poesía: los poetas del simbolismo belga que escriben en lengua francesa. Principalmente Maurice Maëterlinck y Emile Verhaeren. Ortiz lo confirma en una entrevista realizada por José Tcherkaski (1999): 
En ellos confluían las dos preocupaciones mías de entonces. Es decir, la preocupación ya más allá de la cosa política que tenía entonces el movimiento radical aquí, la cuestión social de liberación. En una palabra, las cosas que aquí difundieron las doctrinas anárquicas[...] La poesía belga es riquísima, en un sentido que a mí entonces me interesaba. En el sentido de paisaje y el sentido por otro lado social, cosa que parece contradictoria pero que en cierta gente, no digamos ya poetas, se daba sin choque, o sencillamente en forma dialéctica, aun chocándose. (Tcherkaski)

La difusión de esta poesía de los belgas no se restringía a los círculos anarquistas. También aparecía en el diario La Nación. Leída en clave, repuesto su contexto de producción y sus intenciones, la resolución de los belgas resulta un modelo para Ortiz, pues vincula su interés por el paisaje, sin desligarlo del drama social, e incluso de los anhelos políticos.

El historiador Eric J. Hobsbawm (1980) trazó en un pasaje de su artículo «Socialism and the Avantgarde in the Period of the Second International» un bosquejo de la relación entre aquellos simbolistas y la izquierda revolucionaria, que interesa transcribir en toda su extensión. La traducción es propia:

Menos obvios fueron los vínculos que unieron a los marxistas con el otro grupo principal de vanguardistas de las décadas de 1880 y 1890, a quienes un tanto imprecisamente podemos denominar como los simbolistas. Sin embargo, es un hecho que la mayoría de los poetas simbolistas tuvieron simpatías revolucionarias o socialistas. En Francia, al igual que la mayoría de los nuevos pintores del período - los viejos impresionistas fueron, salvo raras excepciones como la de Pisarro, más bien apolíticos - se sintieron, a 
comienzos de 1890, principalmente atraídos por el anarquismo.

Presumiblemente, esto no se debió en principio a que tuviesen alguna

objeción a Marx - “la mayoría de los jóvenes poetas" que fueron convertidos

"a las doctrinas de la revuelta, ya sea aquella de Bakunin o la de Karl Marx"

(las citas pertenecen a Stuart Merrill) es probable que hubiesen adoptado

cualquier bandera lo suficientemente rebelde - sino a que los líderes

socialistas franceses (hasta el ascenso de Jaurès) no los inspiraron.

Difícilmente podía atraerlos, en particular, el filiteismo escolar de los

guesdistas, al tiempo que los anarquistas no solo demostraron un interés

mucho mayor en las artes, sino que contaban, entre sus primeros militantes, con pintores y críticos de renombre, como el caso de Félix Fénéon.

A la inversa, en Bélgica fue el Partido Obrero Belga quien atrajo a los simbolistas, no solo porque incluía a los rebeldes anarquistas, sino también porque su grupo de líderes y portavoces, provenientes de la clase media culta, se interesaron de manera visible y activa en las artes. Jules Destrée escribió largamente sobre socialismo y arte y publicó un catálogo de litografías de Odilon Redon. Vandervelde frecuentaba a los poetas. Maëterlinck permaneció asociado al partido al menos hasta 1914, Verhaeren devino casi en su poeta oficial, los pintores Eekhoud y Khnopff participaron activamente en la Casa del Pueblo. (Hobsbawm)

El modelo de los simbolistas Belgas le proponía a Ortiz un modo de relacionar la escritura con la política, un modo de vincularlas. Porque es una poesía que se detiene, como la suya, en el paisaje. En el Apéndice se incluye, a manera ilustrativa, una traducción de «Les 
Plaines», de Emile Verhaeren, poema que abre el libro Les Campagnes hallucinées, de 1893 (Verhaeren), realizada por Lucrecia Radyk, con la colaboración de Gustavo Fernández.

En su libro Les Écrivains belges et le socialisme (1880-1913), el profesor Paul Aron (1995) realiza un estudio pormenorizado de la relación entre los principales poetas simbolistas de Bélgica y el socialismo. Da una definición sugestiva al referirse a Emile Verhaeren, en el sentido de que si bien a través de la investigación pudo constatar que sus opiniones, en coincidencia con la de otros grupos radicalizados, eran favorables al arte social ( $y$, tal como lo indica Hobsbawm, puede incluso tomarse como poeta del Partido Obrero Belga) su obra, por el contrario, no proclamaba abiertamente pretensiones sociales o directamente socialistas. Esta relación particular entre experiencia militante y obra poética es absolutamente pertinente para apreciar el punto en que se para Ortiz.

Pero existe aún otro modelo, quizás tan significativo como este que le brindaron los belgas, rastreable en el movimiento modernista. Fue Martín Prieto (2005) quien dio por primera vez esta clave de lectura, al explicitar el modo en que la poesía de Ortiz dialoga con la esa herencia poética e intelectual. Más que con Lugones, a quien Ortiz respeta pero de quien también sospecha, Prieto lo vincula directamente a la figura de Rubén Darío:

«Sí Darío, para devolver musicalidad al verso y a poema trabajó sobre formas fijas — remozando algunas, rescatando otras, resignificando otras más-, Ortiz aprovechó toda la experiencia modernista agregándole la utilización de un instrumento para trabajar la musicalidad de versos y poemas: los signos de puntuación» (J.L. Ortiz, Obra Completa 117).

El diálogo entre Ortiz y Darío puede llevarse hasta un nivel profundo, que involucra la propia concepción de una poesía social, con sus anhelos y posibilidades. Son notorias, en este 
sentido, las similitudes entre las conclusiones del extenso capítulo que Pedro Salinas dedica a «La poesía social» en su libro La poesía de Rubén Darío, cuya primera edición es de 1948, y ciertas precisiones que brinda Daniel García Helder sobre la «elegía combatiente» de Ortiz en 2005.

Para ello es necesario, en primer término, reponer los términos en que Salinas concibe la poesía social:

La poesía social es la originada por una experiencia que afecte al poeta no en aquello que su ser tiene de propio y singular, de inalienable vida individual, sino en ese modo de su existencia por el cual se siente perteneciendo a una comunidad organizada, a una sociedad, donde sus actos se aparecen siempre como relativos a los demás.

La pertenencia a un grupo humano se puede sentir en varias maneras. En una de ellas, el individuo se proyecta hacia el pasado de una colectividad humana de gentes desaparecidas, de muertos, que él continúa y representa en su voz. Es el modo histórico.

En otro, el poeta se vive como miembro de una comunidad cuyas características las fija el hecho de habitar secularmente un mismo lugar de la tierra, en convivencia de usos, lengua, etc. Es el modo nacional, que puede reducirse hasta el regionalismo, o ensancharse hasta la continentalidad. También puede definirse la sección de sociedad en la que se ve inserto el poeta por la participación de los que la integran en un credo social o político idéntico. Es el modo político. Dicho sea de paso, la costumbre de reservar para este tipo de poesía tan sólo el nombre de poesía social se me antoja 
abusiva e impropia. Las obras nacidas de cualquiera de los modos de sentir la sociedad son todas propiamente sociales. $Y$ a las de este apartado les corresponde, en propiedad, el nombre de poesía política, con su secuela de poesía de propaganda.

Y cabe, por último, el caso de que el sentimiento de comunidad sea vivido por el poeta, sin limitación alguna; no por referencia a tal o cual sector de la sociedad de los hombres, sino a toda ella, a los hombres del universo. Es el modo humanitario. (185-86)

Salinas se vale de estos «modos» para penetrar las diferentes etapas del variadísimo itinerario de la poesía social de Rubén Darío. Pero encuentra como sustrato de todos ellos una idea: la relación entre la poesía y la paz. El anhelo de paz al que arriban, una y otra vez a lo largo de los años, los poemas sociales de Rubén Darío. Independientemente, podría decirse, del «modo». Salinas va incluso más lejos y cierra su capítulo dando una maravillosa enumeración del futuro con que sueñan los poemas de Darío:

Contra esa trágica modulación negativa de la vida social que es, aún, la triste realidad moderna, está el sueño del futuro, la confraternidad, la vida en común de todos los humanos en concordancia y armonía. Lo que se les ha negado a las gentes en el pasado, y sobre todas las naciones de la faz de la tierra, la paz, se les promete ahora —o se lo quiere prometer él ahora - en el Canto. Generosidad humana, amor desbordado por todos los prójimos, libertad para la creación de las obras del hombre, disfrute de ellas en común, imperio de la fraternidad, esos son los materiales con los que Rubén Darío labraba, en su imaginación y su deseo, la ciudad futura. Y ese ideal universal 
de amor y paz es el que no deja de sonar de poema en poema, como la nota más inmaculada de su lírica social, que así viene a ganar un hermosísimo aspecto de monumental unidad. (220-21)

Por su parte, Daniel García Helder culmina su ensayo «Juan L. Ortiz: un léxico, un sistema, una clave», que acompaña la Obra Completa de Ortiz, presentando el sustrato de la «elegía combatiente» de Ortiz:

El sujeto contempla la belleza natural, entre cuyos accidentes de forma y movimiento todavía se perciben, como un remanente de la analogía profunda que debió haber brillado en la superficie durante la edad dorada, ciertas relaciones o correspondencias; la nostalgia de este pasado mítico, sin embargo, no es tan enérgica ni sostenida como la esperanza de un futuro en que se dará "la gran relación" o "comunión total”, utopía que a veces parece coincidir con el socialismo, pero que por lo general se presenta de un modo abstracto, difuso, cósmico. En el espacio abierto entre ese pasado y ese futuro míticos, el drama del presente contrasta con la belleza natural, interfiriendo su contemplación. Esta coincidencia subjetiva de la adversación es el dedo en la llaga de la poesía de Ortiz, cuyo peculiar concepto de la elegía y aún del género lírico se cifra todo en ese pero. (J.L. Ortiz, Obra Completa 144)

Las miradas de estos críticos obran como sumarios y organizan un significativo punto coincidente entre la poesía social de Ortiz y la de Rubén Darío: aquel que proyecta el pasado 
mítico, la edad dorada, hacia un futuro utópico de comunión total entre los hombres, con plenas libertades para producir y acoger el arte.

\section{Una poesía comunista no partidaria}

En un pasaje de las Memorias de un provinciano (transcripto en el Apéndice) Carlos Mastronardi traza una preciosa estampa de la figura y la vida de Ortiz en Gualeguay de la cual se desprenden atributos del poeta condensados en una serie de expresiones: Excéntrico, hereje social de hábitos singulares, vida que no se deja atrapar, vida que no se centra en la avidez ni en los bienes concretos, disposición extraordinaria para la amistad, sensibilidad para inclinarse y recoger animales heridos, cuidarlos, integración con la naturaleza. Más allá de la mención de los retratos de Tolstoy y de Barret que colgaban en su casa, más allá de los nombres, es la propia experiencia de Ortiz la que, tal como la muestra Mastronardi, está llena de restos libertarios. Restos vitales que, he aquí lo que interesa, filtran y decantan en su obra.

El paisaje que escoge para su poesía no es el productivo, sino los montes y bajos que se extienden detrás de la ribera del río Gualeguay. Inundables, de tierra poco fértil, no fueron transformados por la mano del hombre. O la selva montielera de su infancia en Villaguay. Un entorno de selva que paulatinamente se perdía en manos de las chacras. Allí se encuentra el poeta, entre las plantas, las flores, los animales, el agua y el cielo. Se abandona al éxtasis de una cierta comunión, sin necesidad de un hacer. Como ya propone, en 1844, Max Stirner en El único y su propiedad: "Un hombre no es "Ilamado" a nada; no tiene más "deber" y “vocación" que lo tienen una planta o un animal» (Stirner 332). 
El frigorífico camino a Puerto Ruiz, las barcazas cargadas de cereales partiendo llenas de hacienda, las estancias (en las que su padre había trabajado), eso no entra en su obra. Los trabajadores no entran en su obra. Es una decisión riesgosa para la clave «comunista». El pedido de Dujovne (la novela de los frigoríficos) puede sonar exagerado, pero es lo que se espera de un escritor comunista: que escriba sobre el mundo del trabajo, de la producción, de la explotación y, por supuesto, de la revolución. Salvo esto último, el desdén de Ortiz hacia esos tópicos es completo. Mientras que su adhesión a los propios es inmutable: el cielo, el río, la luz, los árboles, los insectos, los animales domésticos, los pájaros, algunos pescadores, las flores silvestres. Sin embargo, no deja de haber allí, en ese paisaje, una clave política. Clave que se compendia de manera cristalina en «Para que los hombres», poema que pertenece a La rama hacia el este, el libro que en 1940 le publicó la AIAPE:

Para que los hombres

Para que los hombres no tengan vergüenza de la belleza de las flores, para que las cosas sean ellas mismas: formas sensibles o profundas de la unidad o espejos de nuestro esfuerzo por penetrar el mundo, con el semblante emocionado y pasajero de nuestros sueños, o la armonía de nuestra paz en la soledad de nuestro pensamiento, para que podamos mirar y tocar sin pudor las flores, sí, todas las flores, y seamos iguales a nosotros mismos en la hermandad delicada, para que las cosas no sean mercancías, 
y se abra como una flor toda la nobleza del hombre:

iremos todos hasta nuestro extremo límite, nos perderemos en la hora del don con la sonrisa

anónima y segura de una simiente en la noche de la tierra. (La rama hacia el este 31)

A esa altura, Juan L. Ortiz había dejado en claro que no aspiraba a ser el poeta de los trabajadores, ni del pueblo. Pero la falta de aspiración, la falta de interés por representar a otro, no revierte en falta de compromiso de su poesía para con la realidad, sino que convierte a la poesía misma, de manera programática, en depositaria de una tarea: la preservación de la sensibilidad. ¿Para qué? Para tener siempre, bajo cualquier condición, incluido el triunfo revolucionario, haya un reservorio dónde abrevar.

En el Apéndice se transcribe, completo, el poema «No podéis, no, prestar atención...», de El ángel inclinado, cuya resolución es clara: «la numerosa comunión callada». Este poema plantea una exigencia, una «prueba», una advertencia, donde debería sólo haber palabras de aliento. El poeta no se identifica ni se adjudica un papel revolucionario. Actúa desde una singularidad que pone en tensión la simpleza y eficacia que - se supone- definen al poema militante. Hay una marcada oscilación. Peros. Idas y vueltas. Duda. Oscar del Barco (1996) advierte, en un pasaje de su libro Juan L. Ortiz. Poesía y ética, la implicancia de una enunciación semejante:

La poesía enuncia entonces, balbuceante, su ética: iremos todos hasta nuestro extremo límite, para poder ver, vale decir recibir, con la humildad y dignidad que siempre presagian lo divino, el don, el don del don y no el don de cosa. En este nivel cualquier mandato clausuraría la gracia paradisíaca de 
la libertad absoluta, impidiendo de esta manera el cumplimiento de lo que se da como destino: la "armonía". Esta indefensión de la poesía constituye lo imposible de la política, o es lo que toda política debe desplazar para poder realizarse como política. A la política le repugna lo otro singular que sustenta la vida poética (lo otro es la revelación cósmica y misteriosa del gato, del perro, de los árboles, de todas y de cualquier "criatura"). (108)

La poesía social de Ortiz constituye, desde esta perspectiva que aporta del Barco, lo imposible de la política. A la política le repugna lo singular ( $y$, se agrega, no estratificado) que la constituye: la singularidad de todas las criaturas de la tierra. Esta concepción, esta ética, es en esencia libertaria. En palabras de Christian Ferrer (2006): «El anarquismo, pensamiento anómalo, representa "la sombra" de la política, lo inasimilable» (Cabezas de tormenta sn).

Así, puede decirse que la poesía de Ortiz toma la forma de una contorsión imposible: es utópica, pero jamás inocente. Pues admite, sin ser partidaria, un uso partidario.

\section{Paisaje y política}

Si bien puede afirmarse, con toda justicia, que Ortiz es el poeta del río, de los arroyos, de las colinas suaves, de los pájaros y de las diminutas flores silvestres, se ha advertido ya que la relación con el paisaje que construye no es lineal. No siempre el poeta estará dispuesto a escuchar sus voces sutiles, ni a entrar en comunión con ellas. La irrupción de la injusticia social, de los dramas del hombre se interpone entre ambos, y el diálogo se complejiza. El poeta disfruta de una armonía que le pertenece, pero que no es de todos los hombres. La 
armonía, la anhelada armonía, dirá Ortiz, no verá su realización hasta no ser de todos, hasta que no haya penetrado la intimidad de todos los hombres.

Se ha indicado también, en reiteradas oportunidades, que el paisaje de Ortiz no tiene una correspondencia directa con el medio que lo inspira, y es sencillo probar: allí está la historia de las estancias, de las colonias, de los frigoríficos, del transporte fluvial y del transporte ferroviario de su zona. Para ser más precisos, habría que invertir los términos: sorprende la escasa preeminencia que tiene el paisaje de la poesía de Ortiz en la propia comarca del poeta.

Hacia 1933, Carlos Mastronardi, por entonces de vuelta en Gualeguay luego de un período porteño, impulsó la publicación del primer libro de poemas de Ortiz, El agua y la noche, cuya salida acompañó con una nota de su autoría en El Diario, de Paraná, ese mismo año. Allí dedica un párrafo al asunto del paisaje, dispuesto a despejar desde el vamos un equívoco que juzgaría, al parecer, ineludible. Dice Mastronardi:

Los poemas de Ortiz rebasan lo meramente descriptivo. Antes que inventarios de lo cercano, son paisajes intemporales, carentes de ubicación geográfica y despojados de todo color local. Ha rehusado la botánica y la zoología litoraleñas. Guarda moderación con los ceibos, talas y espinillos; y se muestra discreto con los pelajes, ijares y las caronas. Su poesía desdeña estas facilidades, estos circulantes y poderosos lugares comunes. (Obra completa 442)

No hay en Ortiz la puesta en relieve del color local con un fin reivindicativo. No lo había en el Agua y la noche (1933), ni tampoco lo hubo en los libros que siguieron mientras duró su estancia en Gualeguay, es decir, El alba sube (1937), El ángel inclinado (1938) y La rama 
hacia el este (1940). La diferencia entre estos y aquel libro inicial, es el paulatino ingreso de la política, de los temas revolucionarios en su poesía. En su primer libro, la relación entre el poeta y el paisaje goza de una plenitud sin que medien mayores distracciones. En el siguiente, irrumpe la injusticia, y de la mano de ella, el anhelo del cambio. Se transcribe la estrofa final del poema «Estas primeras tardes», de El alba sube:

Si en todos estuviera esta dicha como una gracia transparente que diera ritmo a los cuerpos, melodía a la voz, amor vivo, vivo, a las almas, sensibilidad a todos bajo los dedos de la música, yo no estuviera triste.

La belleza de la tarde no sería recogida sólo por los árboles, por los pájaros, por el río que la lleva, hacia dónde? por un refinado nostálgico y ultrasensible, sino que tendría también una más amplia, inmediata, y por qué no? más completa expresión humana.

La tarde para todos, compañeros. (53-54)

El golpe de efecto que provoca semejante consigna política, no debe hacer perder de vista un hecho notable que se evidencia en estos versos. El ingreso de lo político en su literatura no comporta un cambio de las matrices constitutivas del paisaje: los árboles, los pájaros, el 
río, en este caso. No hace falta, o quizás no convenga, parece decir Ortiz, apartarse de las propias motivaciones para dar ingreso a la política. Como el péndulo del sismógrafo, sus poemas miden la gravitación de esos asuntos por el modo en que irrumpen, en que hacen temblar el mundo acostumbrado.

Interesa volver sobre un punto, la relación entre el paisaje que aparece en la obra de este período de Ortiz y, por nombrarlo de algún modo, el contorno de Gualeguay y su zona, para indicar que no sólo la historiografía y la experiencia del viaje aportan lo suyo en este asunto, sino, sobre todo, la propia historia de la literatura. No hace falta más que recorrer el paisaje que traza Carlos Mastronardi en su célebre poema «Luz de provincia» (1937) y contrastarlo con recorte que ha realizado Ortiz.

Metódico, Mastronardi (2010) ha reflejado en un ensayo titulado «Nota analítica» las intenciones de la escritura del poema, deteniéndose en los diferentes paisajes de Entre Ríos que lo integran:

Como es evidente, el campo sometido al trabajo agrícola nada tiene en común con las tierras donde priman los viejos hábitos pastoriles. Asimismo, en el área donde la ganadería prolonga el pasado, abundan las regiones solitarias y bravías (campos de islas, las llaman los nativos) que son dominio de la alimaña y el pájaro; su vastedad parece ahondarse en una suerte de abandono ensimismado y salvaje. Así, nos impusimos la tarea de exponer, por lo menos, cuatro aspectos o fases de la tierra alabada: el pequeño pueblo, el campo que es materia de cultivo y generador de mieses, las zonas que tienen por signos el jinete y la estancia y, finalmente, las que ajenas a 
toda evolución (tierras bajas), lucen una olvidada gracia y perduran en una suerte de pureza inmemorial. (Obra completa 565)

De este último aspecto, Ortiz realiza una totalidad. Solo de manera excepcional aparecen en sus poemas el ganado, las estancias, los campos sembrados, la maquinaria moderna. En el ámbito fluvial, puede argüirse lo mismo: las canoas, los sencillos pescadores se imponen sobre la realidad patente que convive con ellos sobre la misma traza, las barcazas que parten desde Puerto Ruiz a través del río dragado hasta la desembocadura en Ibicuy, transportando el ganado y de los productos agropecuarios.

Dentro de los límites de su poesía, nada hay de extraño en su elección, en el recorte, en la construcción de ese paisaje. La delicadeza y la liviandad de su lenguaje le son afines. Sirven para remedar esa fracción intocada, que ha permanecido y luce la cara anciana del territorio. El poeta del paisaje parece haber buscado la constante del paisaje, lo que no ha mudado por la mano del hombre. Lo que se resiste, por sus condiciones, a la producción extensiva que busca generar bienes exportables.

Los casos de Villanueva y Barrandeguy permiten visualizar con mucha claridad el desvío que opera Ortiz respecto de la norma. Se trata de dos poetas sociales nacidos en Gualeguay, que comparten con él, además del origen, la sociabilidad ligada al PCA. En ellos, esa condición de poetas comunistas combinada con el medio, el interior rural, da un resultado estéticamente diverso pero dentro de lo esperable. El desdén manifiesto por las transformaciones que la división internacional del trabajo iba imponiendo sobre el medio y la gente que lo rodeaba, no impidió, y he aquí la cuestión, que la poesía de Ortiz conectase con las principales ideas de izquierda de la época. El poeta optó, por una decisión estética de modo alguno reñida con lo político, establecer su diálogo poético con ese paisaje 
improductivo. En ese marco es que fue dando progresiva entrada al anhelo revolucionario.

Sobre los juncos, entre las ramas morosas de los montes, sopla la tormenta del mundo.

Ortiz enlaza en sus poemas, de manera orgánica, el destino de las lejanas batallas con la cercana comunión con el paisaje. Se transcribe el pasaje final del poema «Una luz tibia...» de El alba sube:

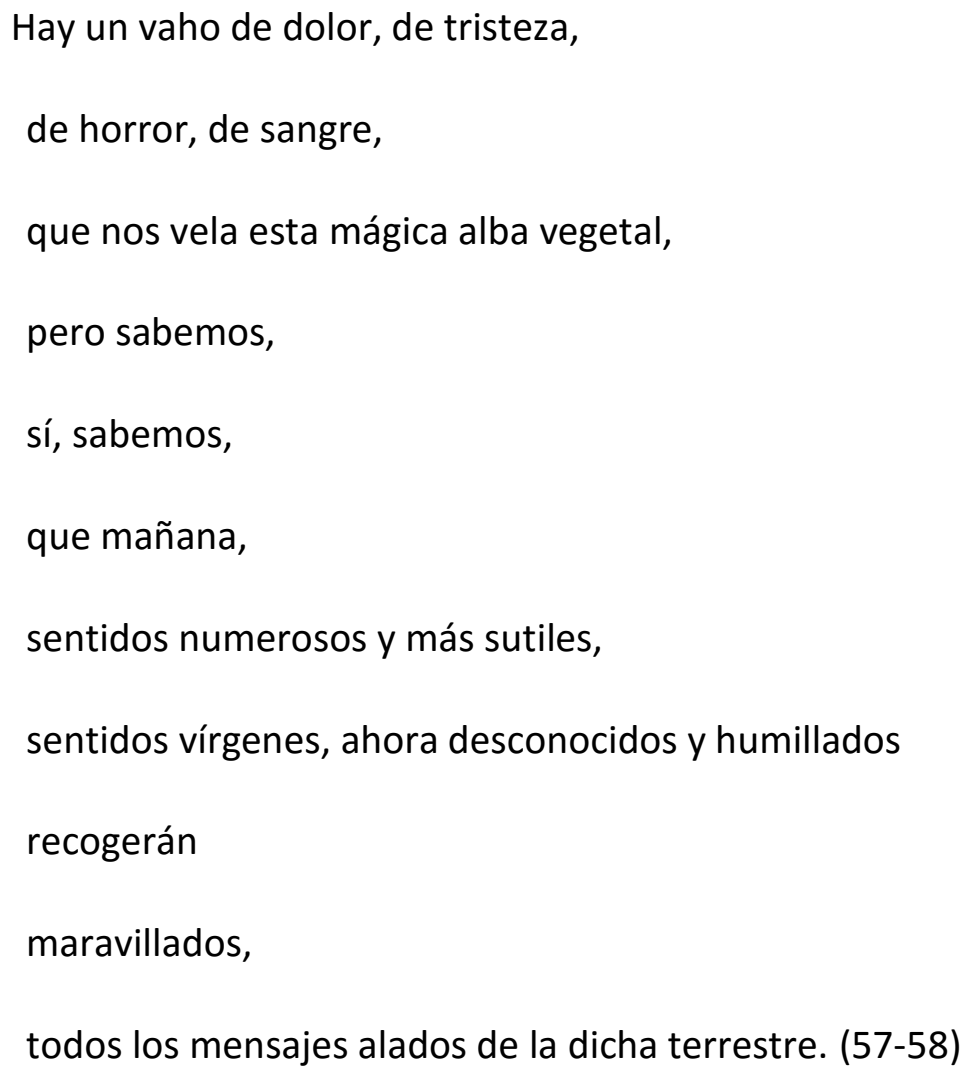

Una poesía dialéctica

A mediados de 1971, Francisco Urondo publicó en el diario La Opinión, una reseña sobre En el aura del sauce, los tres tomos editados por la Editorial Biblioteca que reunían la obra que Juan L. Ortiz había publicado hasta ese momento, más tres libros inéditos. En uno de los párrafos de esa reseña, escribe Urondo: « [la política] no necesita aquí las vestiduras del 
naturalismo a lo Zola, a la que parecía condenada toda escritura comprometida: los hombres no pueden sonreír porque están en el aire, es cierto, la enfermedad y la muerte: el hospital cercano -¿Cómo iban a sonreír? Es el dolor, la patria que troca su sol en libra, sometida al imperio» (Una poesía del futuro. Conversaciones con Juan L. Ortiz. 75).

Urondo pone en diálogo a Ortiz con las corrientes artísticas de una época que planteaba al escritor, al artista, al intelectual, una definición clara. Y esa definición muchas veces implicaba no sólo un compromiso temático, sino fundamentalmente un compromiso formal, en definitiva, la adecuación a una cierta estética. Aporta Gramuglio (2002): «En un sentido estricto Castelnuovo no se ocupa del realismo, pero su manera de entender la relación entre arte y sociedad dependen absolutamente de una idea simplificada de la mimesis: como la burguesía es una clase refinada, supone, el arte burgués es también refinado; como el proletario es una clase rústica, su arte también debe serlo» (Historia crítica 31).

Refiriéndose a la evolución de su primera poesía, Ortiz declaró: «Ahora, mientras permanecía en Gualeguay, era poesía de imprecación rebelde, como se le decía entonces, pero en Buenos Aires me encontré con muchas cosas que me hicieron envainar la espada. No dejé de admirar ese tipo de poesía social que leía con mucho gusto, pero me interesaba la cosa de sugestión, de misterio, la cosa que dice Pavese de descubrimiento que va abriendo zonas» (Juanele.Poemas 127).

La imagen no puede ser más elocuente: envainar la espada frente al a los resultados estéticos de la poesía social de neto corte militante. Es interesante sumar, en este contexto, el saldo que Graciela Montaldo (2006) adjudica a la literatura de Boedo: «una literatura sin utopías [...] Una literatura de la miseria, de los marcados sin redención posible» (Yrigoyen entre Borges y Arlt 325). Ortiz la admira, la lee, la difunde. Pero al mismo tiempo, para su 
obra, «envaina la espada». En ese acto de reflexión, que se conjuga con una experimentación formal intensa, se encuentra la clave original de su poesía política. El conjunto de esos procesos se da con anterioridad a la edición de su primer libro, El agua y la noche, que publica recién en 1933, a los 37 años de edad.

Luego del golpe de Uriburu, la relación entre poesía y política se coloca en el centro de las discusiones. Isabel Stratta (2006) define la discusión que se plantea desde la revista Contra, que marca esa primera irrupción revolucionaria:

No es ya de "nuevos contra viejos" ni de "estética arcaica contra estética moderna" sino de artepurismo frente a arte comprometido, de posibilidad o imposibilidad de la poesía de transformar la vida, de legitimidad o ilegitimidad de las pretensiones revolucionarias del arte. Frente a las preocupaciones estéticas e ideológicas del movimiento vanguardista de los veinte, el debate esbozado en las páginas de Contra ya parece pertenecer a otro ciclo. Lo recrearan, en un nuevo contexto, otros escritores, los de las décadas del sesenta y setenta. (Yrigoyen entre Borges y Arlt 162)

Este arte «comprometido» supone una serie de arbitrariedades que apuntan a destacar, una vez más, el carácter utilitario de la poesía. No descuidar la técnica, advierte sin embargo Tuñón, marcando territorio. Y distingue, en el prólogo-manifiesto a La rosa blindada, de 1936, al poeta proletario (sujeto aún no presente, ni siquiera en la Unión Soviética, es decir: individualidad resultante de la revolución futura) del poeta revolucionario (el poeta del período pre-revolucionario), que vincula la sensibilidad y el conocimiento de la técnica a los hechos que sacuden al mundo «sin que lo político menoscabe a lo artístico o viceversa, confundiendo más bien ambas realidades en una» (La rosa blindada. Homenaje a la 
insurrección de Asturias y otros poemas revolucionarios). Ambas postulaciones, la petición de rigurosidad técnica y la distinción entre poeta proletario y poeta revolucionario, apuntan a desterrar esos lugares comunes en que el boedismo había situado a la literatura social.

En el tránsito del dicho al hecho, esta nueva concepción de la poesía y de la función del poeta en Tuñón, según Stratta, «remodela también el estilo de los textos. En su función de bandera de lucha e instrumento de agitación el poema requiere [...] una vibración oral, un modo de poder ser recitado además de leído» (Yrigoyen entre Borges y Arlt 161)

En los años comprendidos en el período de esta investigación, la escritura de Ortiz ya está formalmente madura. Puede parecer un error hablar de obra madura con una producción tan incipiente, siendo que los que se estudian aquí son su segundo, tercer y cuarto libro, y las apariciones de otros poemas que se dan en paralelo a la edición de los mismos en las revistas de izquierda. Pero es una impresión verificable en los rasgos que definen su línea poética: el léxico ligado al paisaje entrerriano, la musicalidad, el metro libre sin rima, la tendencia a alusividad, la suspensión del sentido, el uso repetitivo y original de la interrogación y el diálogo, la tipografía diminuta; todo esto ya está presente, y se mantendrá a lo largo de sus trece libros, desde el primero al último, sin interrupciones.

El ritmo de la poesía de Ortiz proviene de un movimiento, de una intención que podemos definir como dialéctica. Y esta intención dialéctica tiene en su obra dos sentidos: el primero, que refiere a su acepción más obvia del arte de dialogar, del diálogo; el segundo, más complejo, refleja un pensamiento que se despliega en tesis y antítesis sin conclusividad, un proceso que el poema no concluye. Se transcribe la estrofa final del poema «Con una perfección...», de El alba sube:

Gracias a vosotros, 
al oscuro trabajo de vosotros,

puedo estar yo aquí sentado

mirando cómo el cielo último al morir

vuelve su faz hacia el jardín,

y éste quiere subir y da dos o tres notas luminosas

antes de exhalarse todo para la noche.

Cómo se corresponden estas muertes

—¿iverdad, hermanos míos?

Yo oigo el final suspiro de estas frágiles vidas

y me estremezco.

¿Pero qué os doy, hermanos míos,

qué os doy por vuestro oscuro trabajo?

¿Qué os daré?

¿Armas para vuestras guerrillas?

¿Cantos que os prendan alas de fuego a vuestros pasos?

¿Luces sensitivas para las cosas

que rodearán vuestros lejanos hijos

de numerosas y delicadas presencias?

Ah, sólo quizás

simples, torpes reflejos animistas o mágicos. (43-44)

Ese «vosotros», ese referente tan claro y como extinto, son los defensores de la república contra el fascismo. Ortiz construye el poema (cada poema, debería decirse) con un ritmo, un tono y un léxico personalísimos. Lo que lo corre del lugar común de la poesía social es, 
entonces, por un lado la libertad formal, y por otro, la capacidad de incorporar elementos a su propio universo mediante el uso de una retórica dialéctica, que está en la base de su concepción poética. La política no incomoda a Ortiz, no compromete su estética, ingresa a su mundo como ingresan el río, el cielo o las colinas, de manera dialogada.

Si la idea de la revolución tiene algún correlato en la poesía de Ortiz, este puede ubicarse en relación a la noción de la armonía. La armonía percibida de manera individual (por un «refinado nostálgico y ultrasensible», podría reponerse), y no percibida de manera colectiva, representa una falta. Falta que Ortiz enuncia, de manera discreta, como tristeza. La «tristeza de la posesión» de un bien que debería ser colectivo y por el contrario es percibido de manera exclusiva por un «refinado nostálgico y ultrasensible». Ambas definiciones, la del poeta y la de su estado, se extraen de ese poema central de la poesía social del Ortiz, el ya citado «Estas primeras tardes...» (El alba sube 54).

En una entrevista que le realiza el periodista Jorge Conti (2008), Ortiz confesó: La poesía en ese sentido toca o comprende las mismas zonas de las fuerzas necesitadas de expresión y despliegue que, en lo social, a veces están como amordazadas... Siempre que en el poeta se haya hecho visión, que no sea ya una propuesta en lo que tiene de programa o de conceptualización pura, sino que se haya transformado en un hecho íntimo. En ese sentido, todo pensamiento puede dar lugar a una gran poesía. Puede ocurrir, por ejemplo, durante las grandes crisis históricas, como en el caso de los coreanos: cuando invadió el Japón, una poesía que hasta ese momento no hablaba más que del paisaje, de las flores, idiablos!, se hizo drama colectivo y el poeta -tan sensible ante ese hecho como ante cualquier otro- llegó a hacer una poesía 
nacional y política en el mejor sentido de la palabra. Todo lo que es humano puede integrar una poesía, no como ideología sino de una manera que... le atañe, diríamos, o sea, arde, se quema en la combustión esa que es el poeta por razones de su sensibilidad. (Una poesía del futuro. Conversaciones con Juan L. Ortiz. 71)

Al final de su prólogo-manifiesto de La rosa blindada, escribe Tuñón: «Arturo Rimbaud fue la poesía, la gran aventura poética, pero en cierto momento gritó: ¡Cambiad la vida!» (La rosa blindada. Homenaje a la insurrección de Asturias y otros poemas revolucionarios). Fechado también en 1936, este poema de Ortiz, titulado «Perdón joh noches!...», rescata esa última frase:

Perdón joh noches!...

Perdón, ioh tardes de las 3!

ligeras, ligeras, todavía,

frescas aún como acuarelas celestes.

Un hombre que va a pescar.

Una mujer vestida de blanco.

Las orillas del río, amarillas de flores.

Una nube en el cielo y otra nube en el río.

Una sobrevida temblorosa de espejo...

Perdón, oh tardes,

que apenas os haya mirado. 
Y a vosotros, atardeceres de octubre, tan sensibles,

"suite" silenciosa de qué extraños espíritus?

cuyo más mínimo movimiento

me penetraba todo,

perdón!

os he sido casi indiferente.

Noches, casas, mañanas, tardes,

crepúsculos:

cómo sustraerme al drama del hombre,

al drama del hombre que quiere crearse,

modificar el mundo,

cambiar la vida,

sí, cambiar la vida? (El alba sube 39-40)

Puede notarse que no sólo la rescata, sino que al reiterarla en el último verso la somete a un procedimiento típico de su poesía, original y muy efectivo, que consiste en colocar solamente el signo de cierre de la interrogación. Sin la marca de apertura, tal como afirman Héctor Piccoli y Roberto Retamoso en el ensayo escrito en conjunto «Juan L. Ortiz» (Capítulo 105. La historia de la literatura argentina 173-84), la frase queda suspendida en un lugar intermedio entre lo asertivo y lo interrogativo. A esto se suma el efecto ascendente que provoca, sorpresivamente, en el tono de lectura. Mediante este procedimiento, Ortiz suaviza el efecto de los últimos versos, muy directos, de impronta revolucionaria: «cómo sustraerme al drama del hombre, / al drama del hombre que quiere crearse,/ modificar el mundo,/ cambiar la vida,», y con la elevación de la altura del tono de ese último verso, «sí, 
cambiar la vida?», elude la sensación de conclusión, la gravedad del punto final. Aquella síntesis que parecía representar la frase Rimbaud, en relación a la revolución y la poesía, por la sencilla presencia de ese signo parece abrirse hacia otros rumbos.

Un verso que convoca a Rimbaud y a Tuñón, al simbolismo y a la poesía combativa. Un gesto poético que condensa, de manera singular, las aspiraciones de la poesía social de Ortiz. La misma frase que ese mismo año adquiere en Tuñón impronta de combate, de llamada de guerra de la poesía al final de un prólogo que funciona claramente como manifiesto, emerge en el imaginario de Ortiz primero como afirmación, y luego a mitad de camino, en suspenso.

La cita final pertenece a Francisco Urondo, quien en 1971 ubicó de manera certera, y al mismo tiempo desafiante, la respuesta de Ortiz a nivel del continente y de la lengua:

Vallejo abrió una brecha hasta el centro mismo de la materia poética. Del mismo modo, Ortiz ha concertado, ha totalizado una experiencia donde la cultura del continente, de la lengua -con todos sus pasados y hasta sus influencias de mundo colonizado- encuentra una sintonía que Neruda -a pesar de la extensión de su obra- dispersa.

Es casi sobrehumano ese trabajo, un lujo se diría, para hombres tan jóvenes como los que habitan estos países. Es difícil concebir que toda la naturaleza (la cultura: la naturaleza no existe, decía Pascal) se haya filtrado en este hombre sabio y prematuro, tierno como un niño y hábil como un sobrevivientes de catástrofes» (Una poesía del futuro. Conversaciones con Juan L. Ortiz. 76-77). 


\section{Conclusión}

Las diversas hipótesis que se trazan a lo largo de esta tesis en relación a la obra de Ortiz, al ámbito donde circuló, a su relación con las otras propuestas de poesía social contemporáneas, con la historia del país y puntualmente del PCA, responden a la intención de reintegrarlo a su red de sociabilidad, al diálogo entre ideas y líneas poéticas que ocurrió entre 1936 y 1946. En esa trama se luce mejor. Pues si su respuesta poética es individual y singularísima, su sustanciación es colectiva. Es decir, existía la condición de posibilidad de circulación y legitimación para ese tipo tan particular de poesía social dentro del PCA.

La investigación se sumerge de este modo en una escena de gran dinamismo, que incluye a uno de los principales partidos políticos argentinos de la época, múltiples revistas, editoriales, líneas de pensamiento, obras narrativas, etc. De Amaro Villanueva a Raúl González Tuñón; de Emma Barrandeguy a José Portogalo; de Álvaro Yunque a Héctor Agosti, estas búsquedas intentan reponer ese «otro» del dialogo de los poemas de Ortiz. Esos a los que llamaba, sin ningún prurito, «camaradas».

El examen de Tumulto, el libro de Portogalo publicado en 1935, fue una licencia respecto al recorte temporal que apuntó a subrayar, frente a Ortiz, el giro del PCA entre la estrategia de Lucha de Clases y Frentes Populares. Y el modo en que esto se relacionó con las estéticas que se ponían a circular o, mejor dicho, las que pasaron a legitimarse con el apoyo explícito de intelectuales orgánicos como el caso de Yunque y Agosti.

Lo que insinúa Mastronardi acerca del paisaje en la poesía de Ortiz, aquello de «ha renunciado a la zoología y la botánica», puede ampliarse a su aspecto político: ha 
renunciado a los obreros, a los peones, a los frigoríficos, a las estancias y las chacras. Trazar posibles paralelos - a un partido que paulatinamente va desprendiéndose de su base le corresponde una poesía social sin obreros, ni trabajo, que se constituye en el puro anheloes la primera tentación. Sobre todo a la luz del desenlace: el destino fatal conjunto de un partido, el PCA, que sucumbe frente al peronismo; y el de una poesía, la de Ortiz, por años soslayada en su aspecto social, político y en sus vínculos partidarios. Pero basta repasar los trabajos ya clásicos de historiadores del período como Hiroshi Matsushita, Alberto Ciria y Oscar Arévalo, para matizar de inmediato este tipo de hipótesis: El PCA no fue de ningún modo un partido sin obreros, ni mantuvo, como se ha comprobado, una sola línea estética. Tampoco es unívoco el olvido del aspecto social de la poesía de Ortiz. Allí está Urondo y otros tantos poetas que militaron en la década de 1970 y lo recuperan como emblema, en toda su potencia. El frenesí de desplegar una escena no muy frecuentada suele venir escoltado por la tentación de clausurarla. Pero nada más letal para la paradoja que plantea la poesía social de Ortiz en el contexto del comunismo criollo que un relato simplificador. Se trata, en definitiva, de admitir que una poesía de ascendencia simbolista como la suya propone serias dificultades para abordajes como el realizado en esta tesis.

Las posibles líneas que se abren hacia el futuro, por caso el estudio de la AIAPE, de su editorial y sus revistas, como parte de la fábrica cultural del PCA, apuntan precisamente a contemplar con mayor detenimiento la enorme variedad de respuestas que se concibieron en ese período. La de Ortiz tuvo ciertamente un lugar de relevancia. Pero la eficacia poética se vislumbra, como se ha dicho, precisamente en esa trama: un poema no explícitamente político de un escritor comunista, en 1937, es un poema que derrumba el lugar común.

La conclusión a la que se arriba es que Ortiz fue un poeta social, un poeta comunista con plena consciencia de su lugar, un intelectual instruido, sensible y laborioso que resolvió 
elaborar una respuesta personal y dialógica antes que apoyarse en las estéticas imperantes en la sociabilidad en la que estuvo inmerso.

Como ya se ha dicho, este construye sus poemas con un ritmo, un tono y un léxico personalísimos, ligado de manera sustancial al paisaje que recrea, y que no se ve afectado por la irrupción de lo político. Esto que se infiere es, en verdad, aquello que ya divisó Agosti en su ensayo sobre él en 1939: «La esencia de su poesía está en el paisaje. Pero su trayectoria queda determinada por la conciencia del servicio social de la poesía» (Defensa del realismo 112).

Esto último, el «servicio social de la poesía», puede resultar llamativo o, mejor dicho, excesivo. Pero no lo es. Allí están, para probarlo, los poemas publicados en Claridad y en los órganos de la AIAPE (Nueva Gaceta y Unidad); su poema «A los poetas españoles» incluido en el Cancionero de la Guerra Civil Española, en 1936; y su cuarto libro de poesía, La rama hacia el este, publicado por el sello editorial de la AIAPE, en 1940. Además, sus palabras de puño y letra en la carta a José Portogalo, fechada el 16 de marzo de 1939: «Ud. comprenderá que algunos viajes más no pueden se[r] decisivos en nuestra necesidad más profunda: la expresión lírica, fuente de nuestras alegrías y dolores más vivos, y forma también, no tan intrascendente como se cree, de nuestra participación en la lucha por un mundo mejor.

Agosti confiere a la tarea de Ortiz, de ese «lírico de temperamento casi elegíaco», un status combativo en el plano de la disputa ideológica: «Manifiéstase, pues, el servicio social que corresponde al poeta. Ortiz ha descubierto en sus poemas esa lacerante contradicción de nuestro mundo contemporáneo. No hay espacio para los versos en esta sociedad convulsionada que asiste al fin de un ciclo civilizador. La civilización capitalista, por otra parte, ha sido fundamentalmente una civilización antipoética». El sentido militante de esta 
interpretación es insoslayable, como también son insoslayables las razones que lo sustentan. En esta tesis se ha afirmado que Ortiz instaura al poema, no al prólogo, ni al manifiesto, ni al ensayo, como el lugar donde la poesía se piensa a sí misma, donde piensa su función, donde dialogan sus territorios y se deslizan sus aspiraciones. Pero, y en este sentido interesa la mirada de Agosti, no lo hace en cualquier momento, lo hace precisamente cuando está siendo llamado de manera drástica al combate. Consuma una poesía reflexiva en medio de lo que Halperin Dongui llamó «la tormenta del mundo». Y adjudica a la poesía, a su vez, la función de mantener a resguardo de las inclemencias del combate aquello por lo que se lucha. Sin ir más lejos, la dicha de la comunión entre el hombre y el paisaje.

El ingreso de lo político en su literatura no comporta un cambio de las matrices constitutivas del paisaje: los árboles, los pájaros, el río, en este caso. Con agudo sentido estético, Ortiz altera lo que parece ser el derrotero inevitable de buena parte de los poetas sociales a partir de la década de 1930, en cuyos poemas, junto con la política, con el anhelo revolucionario, ingresan los temas revolucionarios, los motivos de la lucha.

Sobre el paisaje, se ha insistido en que no escoge el productivo, sino los montes y bajos que se extienden detrás de la ribera del río Gualeguay. Tierras inundables, poco fértiles, que no fueron transformadas por la mano del hombre. También la selva montielera de su infancia en Villaguay. Un entorno que paulatinamente se perdía a manos de las chacras. Allí se encuentra el poeta, entre las plantas, las flores, los animales, el agua y el cielo. Se abandona al éxtasis de una cierta comunión, sin necesidad de un «hacer». Como en aquel pasaje de El único y su propiedad, de Max Stirner: «Un hombre no es "Ilamado" a nada; no tiene más "deber" y "vocación" que lo tienen una planta o un animal.» (332) Es el resto libertario en el poeta comunista. 
El ajuste en la imagen de Ortiz, basado en múltiples testimonios, bien puede resumirse en la inédita estampa de Mastronardi: «Por lo demás, el comunismo, por estos pagos, no pasa de una corazonada que aún no asume formas concretas. El ambiente hostil y la excesiva fiscalización propia de las colectividades pequeñas traban su acción. Además, falta capacidad de sacrificio y no existe ese desprendimiento heroico y total que las posiciones ideológicas extremas suelen reclamar. Excepción hecha de Ortiz -cuya fácil y natural adecuación a todas las formas de la santidad no me cansaré de alabar- no existen fervores totales dentro del bermejo movimiento local» (Carta a Cesar Tiempo. 16 de junio 1935). Esta novedad que supone la imagen de Ortiz como militante comunista, sobre los niveles de circulación de su obra en ese circuito entre 1936 y 1946, representa quizás el aporte más significativo y original de esta investigación. Sobre todo en la alteración que supone frente a la imagen habitual y más extendida que se tiene hasta hoy sobre el poeta. El hecho de que Ortiz haya sido a su vez colocado por los propios comunistas - como el caso de Agosti, pero también Álvaro Yunque- en la cumbre de la historia de la poesía social argentina, multiplica saludablemente esa perplejidad. 
Apéndice 
«A caballo, a pie, a nado, en bote»

Salvadora Medina Onrubia, Fray Mocho, 6 de marzo de 1914.

He aquí un muchacho criollo, valeroso y temerario, que sintiéndose artista y queriendo triunfar, abandona Entre Ríos, su provincia natal, y sin más patrimonio que una delirante fe en sí mismo, se viene a Buenos Aires a vivir... ¿A vivir de qué? A vivir, iqué ironía!, de sus dibujos y de sus poesías. No teniendo dinero, sale del Paraná. Primero, a caballo; en seguida a pie; luego a nado, y por fin, en bote... Y así pudo llegar a Buenos Aires. Se llama Juan Ortiz. Es un muchacho triste, está solo, pero es de los que llegan.

¿Su historia? Es una historia sin aventuras. Es la historia vacía de todos los chicos que pueden llegar a tenerla.

Hijo de la aldea, vivió allá siempre. Dibujaba. En la escuela del Paraná sus compañeros nos peleábamos por guardar sus dibujos. Retrataba a sus condiscípulos, y en las tapas de los libros hacía las caricaturas de los maestros.

Cesáreo Quirós vio los dibujos de Ortiz. Y bien sabía Quirós que cualquier pibe de cara sucia que en la escuela traza cinco rayas, puede llevar escondido un artista futuro. Y en Ortiz lo vio perfectamente. En aquel tiempo Quirós, rodeado de todos los chicos del barrio, en un barracón del Paraná, lleno de luz, trabajaba para obtener su primer premio en la Exposición del Centenario.

Quirós y Ortiz se hicieron amigos. Quirós dejó al muchacho rayar y pintar... Y cuando regresó a Roma quiso llevárselo. “En este chico hay un artista, un bravo y verdadero artista... Estudiará bajo mi dirección y le conseguiré una beca del gobierno", se dijo Quirós. 
Y la madre de Ortiz, una gruesa señora muy buena, se opuso. Ella lo quería mucho; no quería, no podía separarse de él. Obstinada, la pobre madre muy buena, lloraba, y Quirós se fue solo. Se quedó triste el chico como un pájaro salvaje al que, queriéndolo mucho, le hubieran cortado las alas para evitar que se fuera. Y siguió su vida de siempre, un poco más triste y un poco más loco...

Después empezó a hacer versos... Yo no los leía. Un chico flaco, loco, que dibujaba, que se ponía corbatas grandes, negras, y hablaba atropellándose... ibah!...

Sin embargo, una amiga díjome un día: “¿Cómo es posible que se publiquen los versos de Ortiz?... Son horribles, sin pies ni cabeza, llenos de disparates, hasta indecentes, impropios de leerlos señoritas..."

Y mi amiga, que lee mucho, que se sabe de memoria las obras de "Carlota y de Carolina" y se peina muy bien, se escandalizaba. Entonces, idebían tener algo de bello los versos del muchacho! ... Una siesta, aburrida, abrí los diarios y quise leerlos.

¡Algo de bello!... Ortiz es más artista con la pluma que con el lápiz. Sin embargo, son versos malos, a veces tienen ripios, chocan... Con ideas hermosas que llegan a los nervios. Versos llenos de rugidos. A veces una palabra rebuscada... “Pero, eso no importa. Llegará. Vencerá", decía yo. ¡Qué rabia!... se reían. ¿Por qué no podía él tener talento? ¿Por qué? ¿Por haber nacido pobre en una aldea? “Por eso, por eso mismo había que creer en él."

Un día Ortiz resolvió venirse a Buenos Aires. Estaba aburrido. Estaba decidido y se iba "mañana". No tenía dinero; llegaría allí con unas monedas... pero llegaría, a caballo, a pie, a nado y en bote... 
Y salió sin más equipaje que su cerebro, llenos de ensueños los bolsillos, y sin novia que, Ilorando, agitara el pañuelo blanco "bajo un cerezo en flor"... (En la vida pasan las cosas al revés que en la literatura.)

Y esa mañana, con su melena rizada y su corbata negra y flotante, tan anárquico, tan bohemio, tan lírico, desapareció de su casa. Se fue solo. Y él, que pudo haber ido marchando seguro por su ruta de porvenir trazada por uno que venció, sé fue solo, pobre, triste, a tirarse de cabeza en medio de la vida para que ésta, imala!, le matara sus sueños... ¡Pobre chico! Es hermosa la bohemia; muy hermosa para leerla y para mirarla. Ahora, en Buenos Aires todos le prometen. Pero el pobre chico tiene hambre... iSufre! Sin embargo, no decae su fe. iQué bello es eso!

Salvadora MEDINA ONRUBIA. 
Reseña de El alba sube, de Juan L. Ortiz (Carlos Serfaty)

Unidad, año 2, n 1, p. 16, agosto de 1937.

Un cuaderno de formato grande, de carátula levemente marfil, con letras muy finas, en tinta azul bronce: Juan L. Ortiz — "El Alba Sube"- 1933-36.

Dentro 64 páginas de legítimo papel pluma, blanco, muy liviano, con 35 poemas impresos en letra pequeñísima.

Se alegra uno, describiendo este libro. Pocas y veces una edición responde así, al espíritu de su contenido. Y esto, más importante: pocas veces un volumen de poemas es, tanto, el poeta mismo.

Cuando Juan Laurentino Ortiz nos entrega un libro suyo, - y ya (o habíamos observado Cuándo "El Agua y La Noche", aunque menos precisamente- nos quedamos pensando como él permanece, impasible e intacto, con su larga boquilla en los labios y el ademán inconfundible rasgando apenas él aire. Sin embargo, es así, Ortiz realiza el milagro de dársenos íntegramente y quedar, empero, intacto para las próximas entregas. "El Alba Sube", es una superación de "El Agua y La Noche", sin eclipsar, sin embargo, aquel bello resplandor.

Acaso nos desconcierte un poco a los hombres de 1937 ese tono que hace diáfanas las palabras y nos envía el sonido de cada sílaba, milagrosamente atenuado. En época de tremendos problemas sociales nos sacude la serenidad de este hombre -que personalmente y zangoloteado por esos mismos problemas - sé atreve a salvar, incólume, su verso. ¿’Pero significa esto un aislamiento, una sordera voluntaria a los problemas de los hombres? 
Juan L. Ortiz es demasiado sincero, su verso demasiado desnudo para traicionar a su época y a su clase, y el estremecimiento de la angustia colectiva pasa por sus mejores poemas, noblemente, sin desfigurar el tono y sin falsos huracanes que transformen el clima "Ráfaga del vacío" o "Estos hombres.,.." pueden ser nuestros. El final de "Estos hombres..." es de un lirismo humano, profundo y trágico.

Solo siente

que a la inseguridad terrible de su vida

se une la tierra negra, que en su casa deshecha no la

espera la rodeada de risas, . sino un montón oscuro de infantiles figuras contraídas y la desesperada femenina, pregunta cotidiana".

Y tras esas pinceladas, que parecen mostrar un carbón de Fació Hebequer, las dos últimas líneas, como un resplandor:

Pero yo sé que un día, verás, oh hermano mío, en el horizonte temblar, bajo el roció, para tí, limpios jardines"... Y en estos poemas, o en los otros, más personales/ desborda su personalidad y nos hace sentir y respirar la atmósfera diáfana de su mundo. Y comprendemos sus enigmas, ante "La noche y la mujer".

¿Dónde empieza la una y termina la otra?

Frente a la belleza del mundo:

¿Pero el vacío negro, el escalofrío intermitente del abismo?

o en el pueblo azul y quieto 
¿viven aquí los hombres, 'viven aquí los hombres?"

Juan L. Ortiz es un poeta maduro. Su voz llena, es algo de excepción en esta parte de América.

Carlos Serfaty. 
Poetas sociales de la Argentina. 1810-1943. (Selección) (Álvaro Yunque)

Editorial Futuro, Buenos Aires, 1943.

Peón de estancia, de Marcelino M. Román

Aunque muy poco les hago

al canto y al guitarreo,

canto ya que me lo piden:

disculpen si chamboneo.

De vacunos y lanares

y yeguarizos hablemos;

de curar los abichados

y de componer los cercos.

De señalar las ovejas

y de capar los terneros,

de vigilar las aguadas

y recorrer los potreros.

Hablemos de los caballos

y hablemos de los aperos;

del fuerte sol del verano,

de la escarcha del invierno. 
Hablemos de lo que quieren

pero sin tocar el sueldo;

si quiero tener muer

no sé cómo la mantengo.

Hablemos de las carreras,

de la taba y de los juegos;

de los tiempos de elecciones

y del asado con cuero.

Hablemos de las haciendas,

de los chanchos y los perros,

mas no de las injusticias

que los pobres padecemos.

Me pidieron que cantara

y traté de complacerlos.

Me tendrán que disculpar

si es que en algo los molesto. (44-45)

Don Escolástico Junco, de Amaro Villanueva

“Ojalá cantara un gallo 
Pa saber dónde me hallo."

(Dicho de don Escolástico).

Se me ha terminado el sueño.

La noche ya se da vuelta.

Un silencio sin alambres

se estira en el campo afuera,

mientras encrespa el lucero

su porfía de alma en pena,

y la luz anda queriendo

como enagua de soltera.

Un fuego recién despierto

por la cocina bosteza:

Don Escolástico Junco

con el cimarrón solea,

revisándose, callado,

las ternuras que le quedan.

Porque es de aquellos antiguos

que se hablaban con la yerba

sola su alma con el mate

para saludar la fresca.

Como aguaribay del monte,

tronco, barbas y melena,

se crecido de tiempo 
y hasta con ramitas secas.

En esa luz del fogón,

que los rasgos le subleva.

-Si no imprudencio, don Junco...

-Pase, que un amigo alegra.

Y después de los modales

de la urbanidad campera,

con el gusto de los mates

desentumimos la lengua.

La voz de don Escolástico,

reposada, limpia, gruesa,

tiene el respeto ganado

desde que sale a la puerta,

y unos nombres de otro tiempo

que la bombilla calienta.

De Punta Gorda y Caseros

nos vamos hasta Cepeda,

y al Don Gonzalo crecido...

-Con López Jordán a cuestas,

que fue, como militar,

bastante huevo de yegua.

Nos enchiqueró en tres aguas,

con los otros de tranquera. 
Sarmiento probó los rémingtons

en la gente montielera,

que era de lanzas y sables

y fusiles sin cartera.

Con los de repetición

nos pegaron una buena.

Pero más nos mató el agua

que las moras extranjeras...

Y con sabor a otros días

larga la verdad completa:

-De tanto mirar la muerte

le perdimos la vergüenza.

—iQué tiempo, don Escolástico!

¡Pucha! Si aquello volviera...

- Los que tienen que volver

son los hombres que lo entiendan.

Porque el tiempo es uno solo,

por más que le saquen cuentas...

“El tiempo sólo es tardanza,

dijo Fierro, en otras épocas,

de lo que está por venir."

Y así estamos, con la espera...

¡Si este tiempo es el de siempre, 
pero perdido en sonseras!

Que si el caso se da así...

Que si de la otra manera...

Que si nos darán un alce,

que si nos darán más leña...

Que qué pensará el ejército...

Que qué los que nos aprietan...

que sin nos dejan votar, vamos a emplear la libreta...

Que si hay que elegir un hombre, que si hay que elegir una hembra.

Que si estamos en el mundo, que si estamos en América.

Que si nos acomodamos,

se va a acomodar la tierra.

Que si vendrá bien unirnos,

O hacernos la... intransigencia.

Que si no será un peligro

tal o cual hombre que piensa.

De tanto dejarse estar

estamos donde nos llevan.

Pero ninguno se dice

si es por maulas o trompetas. 
Mientras por toda la patria,

le dijo Chano a Contreras,

"Una tropilla de pobres

canta al son de su miseria".

—“ ¡No es la miseria mal son!”...

—iQué ha de serlo, Villanueva!

Si a "lo que está por venir"

hay que ayudarlo a que venga,

como que hay que echar la vida

por delante y sin pereza.

Ya es tiempo de hallarle el filo

al cuchillo y la vergüenza;

de no andar mirando arrugas

ni tentando por las buenas;

de ensillar el malacara

y acortar las estriberas,

y galoparse una noche

para quedar donde quiera.

Tiempo de llevar bombachas

pero tenerlas bien puestas;

de sacar la voz del pecho

y no de entre las polleras.

Tiempo de bolear el anca

donde la ocasión se ofrezca. 
De campear la libertas,

por el camino que venga.

Y de no dejarse andar

con el miedo entre las piernas.
A "lo que está por venir"
hay que ayudarlo que venga.

Saltan las barras del día

gallos, pájaros y ovejas.

Y en un relincho limpito

todo el campo se presenta.

Alumbra, desde un rincón,

medio frasco de ginebra.

Me convida con un beso

y cuando, a su vez, lo besa,

murmura don Escolástico:

_ ¡Pa desparramar la yerba!... (32-36)

Sentido de la lluvia, de José Pedroni

Llueve.

Llueve por todas partes:

sobre el trigal sediento;

sobre las largas calles. . . 
Las palomas se esconden

y la tierra se abre.

Sólo aquí, en la herrería,

no llueve para nadie.

Tapándonos el cielo

están los techos grandes,

y abajo está el estruendo

y el caluroso aire.

Pero la lluvia es buena.

Tiene algo de madre.

Escondida entre los pájaros

me esperará en los sauces.

De los trabajadores

es la lluvia en los árboles.

¡No ahuyentar a la lluvia

que espera en el follaje!

Certificado de trabajo, de José Pedroni

Papá Tuñín: Hoy te dieron de baja. 
Es lo peor que pueden haberte hecho.

De regreso a tu casa,

llevas un tiro en el pecho.

¡Qué dirá tu mujer;

qué tu hija, acostumbraba a ver

en tu persona al jornalero impar!

Dejarán de barrer.

Se pondrán a llorar.

Papá Tuñín, el capataz activo

que valía por diez:

desde hoy eres el hombre

que "fue jefe una vez",

con una pensión en diminutivo,

como tu sobrenombre.

En mi función de contador,

por última vez escribo tu nombre

-Antonio Bonocuore-

en el libro mayor

y lo encierro en un trazo

envolvente, de abrazo,

que para mí tiene un símil: el lazo,

y una equivalencia: la flor.

Mañana 
-si es que esta noche puedes dormir-,

al primer grito

salvaje del pito

saltaras de la cama

y te empezaras a vestir.

Será un segundo nada más,

un terrible segundo

"en una apartada región del mundo".

Luego te dirás,

mirándote al espejo,

avergonzado:

-iQué horror, Papá Tuñín!

No es para ti el llamado.

Tú lo ves, eres un viejo.

Sirves para un jardín.

Canto a Juan, de José Pedroni (primera estrofa)

No eres no un general, ni un sabio, ni un artista;

eres el maquinista

de la fábrica, oh Juan! (Yo soy el contador,

aunque también poeta, que no todos, lector...)

Tu función, pues, no es otra que hacer el primer fuego,

tocar a tiempo el pito, mascullarle un reniego 
paternal al manómetro y sentarte a fumar.

¡Ah! también madrugar,

cosa mucho importante como sabes decir,

y con razón, por cierto, que a tu poco dormir

le debes el honor de ser el primer hombre

del pueblo que en el cielo vio el cometa sin nombre,

aquel que Martín Gil... Pero éste no es el cuento.

Lo que quiero cantar es tu sometimiento,

y eso que hay en tus ojos, y en tu paciencia ancha,

y en el temblor de hoja de tu mano sin mancha,

y en tu andar no común de can que sigue al amo,

y en tu buena palabra dicha en mal castellano,

y en el pan de tu alma, y en tu color de pan,

(¿iel de la muerte?) oh, Juan [...] (11-15)

Labo Lekaike, de Luis Gudiño Kramer

El rico tiene casa grande,

nojotro labó cuchuquic,

imec, apenita, agata...

Apretaitos... amontonaitoj,

y el suelo 
pa dormir.

Imec apenita, agata.

Lo plantamo un yuyo,

viniendo la comisión

con el desalojo...

Indio haragan, ni un árbo

plantan...!

Loyak lósok

carriando nojotro

pal rico.

Pagteghé palók

agata, nojotro.

Y hermanos invidiando,

peliando chupaus,

cabandos.

Blancos se teniendo odio.

Nojotro pobres, sucios.

Humo jediondos,

sábalo asau, pa todos! (30-31) 
«Visión del campo argentino» (Emma Barrandeguy)

Contra. La revista de los francotiradores, UNQ, Bernal, 2005, p. 454-57.

Visión del campo argentino

Vengo del campo con mi voz,

no traigo más que eso y mi juventud.

Mis seis primeros años los emborraché de cielo,

los que siguieron de incienso en las iglesias católicas

y de interrogantes.

Tengo diez y nueve años

y me adiestré las manos para desgarrarme de todas las cáscaras.

Una vez en una tribuna tibia

dije un tibio discurso contra la guerra,

fue un 28 de julio

y fue mi iniciación,

Me repudiaron

las amigas "Hijas de María"

porque había cambiado la cinta celeste

y había enderezado mi rebeldía:

me repudiaron 
en el pueblo mío de las "casas chatas"

y de las chatas almas.

Yo he recorrido los campos en ancho y largo

y he visto los alambrados insultantes

y las covachas miserables de los campesinos,

y he sabido

de los que hacen carbón entre los montes

y esconden sus mujeres cuando viene gente

porque no tienen ropa con que vestirlas,

y he visto las leguas y leguas de las compañías extranjeras

y estancias con luz eléctrica y piezas empapeladas,

y gauchos resignados arañando la tierra

que no da pan,

y "lingheras" por los caminos con una bolsa al hombro,

y chiquilines miserables.

Yo sé de los capitalistas que se quedan

con el pedacito de campo

que los esclavos han trabajado y valorizado,

y han regado con sangre:

yo lo he visto.

Yo sé de las extensiones infecundas y de las otras pobres gentes

enredadas con hipotecas 
y telaraña de leyes

cuyo cuadradito de tierra se reparten los abogados y los ricos.

Yo sé de la angustia

de mirar día a día la cosecha,

de avisorar la langosta

o la lluvia inoportuna

o la inoportuna sequía

o la helada

o el granizo,

y de ver que después de trillado el campo

se va todo en pagar el arrendamiento!

Sé de los ranchos de barro y paja

endulzados por dentro con recortes de revistas

y minados por todos los soles,

surgiendo en la llanura gigantesca

con su miseria

con su suciedad,

con las goteras por donde se entra el viento y la lluvia,

con su "argentinismo".

Yo he cruzado ríos con mi caballo

$\mathrm{y}$ he galopado en los caminos polvorientos 
-que abovedan empresas extranjeras

a costa de hambre de obreros-

y he andado sobre las trilladoras

trillando lino,

y he desgranado espigas coloradas en

las desgranadoras,

y he parado rodeo,

y he visto esquilar ovejas y marcar vacas y domar potros,

y he apretado las manos nudosas de los trabajadores,

y sé cómo está adulterado

el vino que les venden los gringos en los boliches,

y el azúcar, y la yerba, y los fideos,

y cómo les roban a los campesinos

en el peso y en el precio,

y como les pagan los patrones con vales

-aunque esté prohibido por la "Constitución" - .

Yo he ido hasta el río Paraná.

Siempre llanura ante mi vista.

Siempre miseria ante mis ojos.

He visto a los caudillos de la política

repartir carne para conseguir votos,

he visto las escuelas del campo, 
de madera, de zinc, y sin un árbol,

- maestros gana sueldos de mi tierra-

sé de ese i"señor"! y ese respeto

que desgraciadamente

no se les cae de la boca a los explotados

y que está hecho de inercia

y sé de otros que han venido

hasta un compañero mío

a pedirle un revolver

con que matar una vaca para comer,

y aprender después a matar burgueses para vivir.

Traigo solamente la voz del campo

hecha grito y alarido

al servicio de mi juventud.

Porque antes me envejecí en las iglesias.

Y me parecía gloriosa la asfixiante condición provinciana

y la encontraba tranquila

como la encuentran las viejas beatas

y los poetas de antes.

Después me colgaron calificativos insultantes

mis compoblanos,

cuando ya no creí en la diana cuartelera

ni en las campanas parroquiales; 
¡Gracias! Los he llevado con holgura,

tengo erguida mi convicción

y canto.

Algún día, pronto, cuando las leguas

de los capitalistas

estén colectivizadas,

yo me iré a trabajar con los campesinos,

me reintegraré a la tierra.

Ahora,

vengo del campo,

y quiero decir

por sobre las "casas chatas" y las almas chatas,

y a la faz de los rascacielos

y de los obreros

y de los intelectuales libres,

que aquí están sus hermanos esclavos

esperándolos, ansiando despertar

y buscando el momento de estrechar las manos

— castigadas por un mismo dolor-

y listas para destruir los amos.

Dan, 
tierras para el que las trabaja,

máquinas para quien las maneja,

arte para todos los ojos

y paz.

Gualeguay Agosto 5/933. 
«Frigorífico» (Emma Barrandeguy)

Poesía Completa, Córdoba, Alción, 2005, p. 55-60.

Frigorífico

Es día de matanza: me han llevado a mirar el frigorífico.

Cámaras frías, calor de infierno, ruido, olores y obreros.

En la playa de matanza cada trabajador está en su

puesto, - sin charlar, ni pensar, ni descuidarse - frente

a los cientos de reses que desfilan delante colgadas de

roldanas.

El piso de cemento es un solo charco de sangre, agua,

desperdicios donde resbalan mis botines de goma.

Donde los obreros están horas y horas parados.

Un olor terrible infectándolo todo, acre, penetrante, que nos sigue por todos los rincones.

Y las reses se mueven.

Y es intensa la racionalización.

Rápido, rápido: usted mata los animales, usted saca los

cueros - cada corte que le haga es un punto que anota

el capataz y es un descuento en el jornal- usted saca

las entrañas calientes y sucias, usted lava la carne con

cepillos y agua, usted la seca, obrero. Rápido, rápido: 
van y vienen las reses en los rieles del techo.

Y los obreros fijos, fijos, en los puestos de siempre.

Sin hablar, sin cambiarse por toda la jornada.

Ascensores, ruidos, máquinas, hombres, curiosean por

todo mis ojos. Y andaba de paseo, y no sentía vuestra

carne sufrida, camaradas. ¿Por qué no me dijisteis una

mala palabra?

Hierve la grasa en los tachos, se derrite el sebo en las

calderas.

Los hombres sudorosos en un calor de infierno.

Cámaras frías, nieve en los caños.

Los hombres tiritando a dieciséis grados bajo cero.

Cientos de reses diarias alineadas en las cámaras frías.

Carne que va hasta Europa, carne que va a Japón, carne

para soldados, para la guerra, para el que tiene plata.

¿Cuándo carne para 50 millones de desocupados?

El frigorífico ruge con su entraña de máquinas.

Los hombres rugen aunque estén agotados por el

standard.

Resbalaban las suelas de mis zapatos en el agua sucia

de los pisos; me seguía por todos los rincones el olor

penetrante de la matanza; y yo no los veía bien a

ustedes, camaradas, aunque mis ojos curioseaban en

todo. 
Sentía una confusa vergüenza de mis ropas planchadas,

pero no pensaba en los cuerpos agobiados;

los pies mojados; los niños que empujaban carretillas, descalzos;

el reuma que acecha en las piezas heladas; el sudor de los

hombres infames. Quizá sintiera compasión...

¡Maldita compasión, camaradas!

¿Por qué no me dijisteis una mala palabra?

Pero ahora aprendí a verlo todo.

Antes decía: ¡Qué gran empresa!

Hoy digo: ¡Qué gran empresa para las manos vuestras!

Cuando las fábricas sean de los proletarios, cuando los

campos sean de los campesinos, cuando digamos nuestra

palabra, camaradas.

El frigorífico ruge con su entraña de máquinas.

Los hombres rugen aunque estén agotados por el

standard.

Mayo 28, 1935. 
«Poema caminando» (José Portogalo)

Tumulto, Imán, Buenos Aires, 1935, p. 69-76.

Poema caminando

¡Qué lindo, amigos! Éste es un título magnífico para encabezar un poema: Palomas rojas y palomas pardas.

Palomas negras y palomas blancas.

Como estoy conforme lo escribo en las puntas de una estrella y me voy por el mundo bajo el cielo de la mañana.

—¿Se acuerda Vd., señorita Shultz, de mi amor por sus piernas? ¿De mi amor de muchacho de la calle, zumbón, amor alegre, salvaje, y lleno de sueños como sus ojos de señorita que lee novelas?

¿Se acuerda de los cuentos de Calleja, que yo le pasaba bajo el banco, y Vd., de sus muñecos de porcelana, que me regalaba mientras la maestra dictaba una composición de la primavera?

Y, pensando en los Apóstoles de la Poesía -en los poetas barbudos y en los poetas lampiños - digo un montón de malas palabras, silbo un tango de malevo enviudado y me acuerdo de Vds. De vos, Rosita. De vos, Isabel. De vos, Berta. Todas en un solo sexo y en un solo sueño para mi hombría de ciudadano de Buenos Aires.

¿Quién levanta las polleras de las muchachas, amigos? Ellas me dicen adiós desde un puerto - desde las fábricas, desde los talleres, desde las oficinas, tal vez desde los prostíbulos -, y yo estoy solo en la calle, solo - ahora - con mi alma y mis puños. 
¿Quién sostiene los pezones de las lindas dactilógrafas tuberculosas, que ganan $\$ 60$ mensuales, visten como mantenidas y sueñan con un viaje a Hollywood?

Eras tan linda, mi pequeña señorita Shultz, tan linda como la armónica que te regalé una tarde en que el Otoño hacía remolinar sus hojas amarillas en las veredas de la calle Sucre y perros sin dueños orinaban las paredes y husmeaban las piernas de las colegialas guiñándonos los ojos. Ahora te recuerdo, envuelta entre virutas musicales, gritos de canillita descalzo y besos fugándose de las puntas de los dedos. Desde mi raíz de barro subes en espiral hasta mis ojos y me agarras como una trampa, me pinchas como una estrella vacante que gira sola en el aire.

Pero tú eras la hija de un general alemán y yo el hijo de un vendedor de pescados.

Por ti me echaron de la escuela Marcos Sastre. Desde entonces odio a los generales y a las directoras de escuela que leen a Vargas Vila y mueren sin conocer un hombre mirándose en los espejos de la tarde.

Entre mis pies volteo la desocupación, pedidos de La Prensa y el viento, que trae noticias de todo el mundo, se cuelga de mis orejas.

La China arde en un sueño revolucionario.

Los guardias civiles son amigos de García Lorca.

Muchos poetas de Buenos Aires plagian a García Lorca y son amigos de los vigilantes. Los rebeldes de Asturia inventan una historia nueva de España.

Hay otra luna, otro cielo, otro sol en la tierra.

Crecen las ciudades, los ríos, las montañas, los árboles, los hombres y los insectos. También crecen las hierbas, las diminutas hierbas que nos alegran los ojos y nos refrescan la piel.

Alemania se retira de La Liga de las Naciones. 
No sé por qué, pienso en las ligas de las prostitutas y en las ligas patrióticas.

Mi corazón es una entraña joven, en él nace el sueño del mundo.

Hoy debut de la famosa jazz de negros Los Filipinos.

Los nueve negros de Scottsboro sueñan con la estatua de la Libertad.

Laugston Hughes escribe un poema sobre los hambrientos de Harlem.

En el país de los rascacielos y de la doctrina de Monroe se organiza un mitin de desocupados.

Ana Sten aprende inglés y, lo que es más lógico, se acuesta con un director de películas, se pinta las uñas y pasea en voiturette.

En todo Centro y Sud América hay voces filosas que apuntan contra Wall Street. Hay generalitos de chocolate que hacen revoluciones nacionales con oro de Wall Street y soldaditos de carne y hueso.

Pero también hay puños contra Wall Street, y eso es reconfortante, camaradas, reconfortante como una bebida tónica.

Vea Vd. las películas nacionales: Ídolos de la Radio, El Alma del Bandoneón. Gran dirección artística. L. S. T. Radio del Pueblo.

Ah, si te encontrara, hablaría contigo - como en las películas - de muchas cosas. Por ejemplo: ¿Eres ya enfermera? Mira, ahora los capitalistas están preparando otra guerra. Ya no tendrás por qué ir a la tumba de Di Giovanni. Ni por qué hablar de libros. Ni escuchar conciertos. Te bastará con el silbido de los obuses, el ruido de los tanques, el tamborileo de 
las ametralladoras, el aullido de los millones de hombres en los hospitales, en las trincheras, en los campos de batalla.

Esta noche a las 22 horas por S. L. O. escuche al doctor Casalavega. Su palabra autorizada nos dirá del litigio de las dos naciones amigas que en el Chaco boreal se desangran por un palmo de tierra. Para su automóvil use nafta Energina, es la mejor.

Ya sé que eres manicura, Berta. Gastas tapado de piel, medias de $\$ 30$ el par, bailas en una boite y fumas cigarrillos turcos.

A las 23 gran audición ofrecida a la Virgen del Valle con los mejores elementos de esta estación. El mejor laxante San Pellegrino.

¿En qué fábrica te estarás pudriendo los pulmones, te estarás comiendo las manos, el vientre, los ojos?

$¿ \mathrm{O}$, eres una trotacalles de Talcahuano y Lavalle?

Mañana gran acto público en la plaza Independencia organizado contra el monopolio del transporte.

Compre casimires ingleses, son los mejores.

Una noticia: Ha desaparecido el ingeniero Guillermo Marconi y los planes de su último invento.

Otra: Dios está aburrido. Le duele la inmovilidad de sus labios de piedra y el olor a sacristía de su pene enclaustrado.

Un angelito vestido de blanco le ofrece una rama de olivo. Pero él manda cuatro tiradores, dos camisas pardas y dos camisas negras para que lo fusilen contra las nubes por imbécil. 
Un affiche: Prepare su conciencia cívica. Vote nuestros candidatos en las próximas elecciones.

Otro: Sea patriota. Vote en blanco.

Primicia de nuestra broadcasting: Ha muerto el general Pilsudski.

Recuerdo tu muerte, camarada albañil. Te llamabas Pascual y caíste desde un séptimo piso. Nadie dijo tu muerte. Es natural. Hay muchos Pascuales en el mundo y hay muchas muertes como la tuya, amigo.

-Comprendo que el nombre Pascual no es poético, camaradas. A los snobs se les torcerá el culo como la boca de una solterona. Le falta musicalidad. Es grosero. Grosero como el tabaco que solía fumar en su pipa de barro. Pero, tenía dos puños, dos brazos, un corazón: Era un hombre y ahora no lo es.

Pienso que puedo fabricar un soneto para ganarme unos pesos. Un soneto sobre la muerte del general polaco que le agrade al Director de la Biblioteca Nacional, o al Intendente de Buenos Aires.

Fume cigarrillos Condal. Son los mejores.

Ellos suelen dar palmaditas en los hombros y decir: ¡Muy bien, muy bien, amiguito! Luego le firman un nombramiento para alguna administración pública.

Enciendo un pucho de cigarrillo que encuentro en la calle y el viento continúa golpeándome las orejas. 
La mañana es hermosa, hermosa como una mujer recién casada. Fresca, de rodillas redondas, de cintura ensanchada donde germina un mundo. Me pica en las narices el frescor de esta mujer que pasa rozándome la piel.

-Vd. tendrá un empleo bien remunerado, por supuesto, y no ha de papar más que moscas 6 horas diarias.

A Gabriel Miró le duele la humedad de los rincones, suele ver fantasmas en los rincones de su oficina.

Fantasmas que le mean los manuscritos. Por eso no lo admiten en la Real Academia Española.

Pero Ramón Sender da la vuelta al mundo y su voz apunta al alba de la revolución y suelta palomas rojas en las narices del primer ministro republicano.

A Pío Baroja lo asesinaron los académicos.

Jacinto Benavente es un Premio Nobel.

Pero el Máximo Gorki es el avión más grande del mundo.

-No ha de hablar de política ni menos de partidos. Eso sí, conversará de football, de turf, de mujeres; leerá las crónicas rojas de los diarios y hasta si el jefe tolera, comentará las charlas de los tantos farsantes radiotelefónicos que abundan en este país.

Claro que Vd. se cuidará de decir que estos benditos señores son agentes propagandistas del imperialismo yanqui o del imperialismo inglés. Que son escritores mediocres y que sus plumas se mojan tanto en el trasero de un Príncipe que se casa como en el de un pobre diablo condenado a muerte.

No diga, por ejemplo: Dios no existe. $\mathrm{O}$, la guerra la hacen los grandes capitalistas para engordar sus bolsillos. 
Pero iqué diablos!, camaradas. Entiendo que ésta es la pura verdad y me miro los puños.

Alguien me dice que el angelito vestido de blanco asesinado por la orden de Dios tenía un corazón. Pero las balas se lo destrozaron y su sangre era roja.

¿Entienden Vds.? La sangre de todos los hombres es roja y la nuestra también es roja, camaradas. Y esto es hermoso. Por eso me miro las manos y me arranco el alma.

Le hago un nudo como a una corbata de niño. Una de esas corbatas que nunca tuve, y la cuelgo de un árbol.

Fume cigarrillos Condal. Son los mejores.

El viento de tanto frotarme las orejas me afila la voz. Sacude mi alma que cuelga del árbol como un planeta rojo, y se va por las calles, cantando.

No tengo cigarrillos. Pero tengo unos puños firmes como los espolones del gallo de las madrugadas.

De esas madrugadas que empiezan donde nace el cielo. Quiero decir: El mejor resplandor.

Asegure su porvenir. Ahorre. El Banco Popular es el que más ventajas ofrece. L. R. B. Radio Progreso.

Escuchen ahora como último número de la audición matutina Romanza sentimental.

De tanto mover las puntas de las estrellas, camaradas, me sangran las manos.

Pero mi alma es un planeta rojo y yo estoy en las puertas del cielo para servir a la vida. 
«España de Hoy» (Álvaro Yunque)

España: 1936, Buenos Aires, Grabo, 1937.

España, la de hoy, cantarte

Quiero con aire de copla.

España de hoy, la que vive,

más que nunca luchadora,

la del minero asturiano,

resurrecta España roja,

la que le arrancó las uñas

al águila napoleónica,

la que encendió de rebeldes

nuestras multitudes criollas...

España, la de hoy,

cantarte quiero con aire de copla.

La de ayer, la España negra

Sus huestes insurrecciona,

Tira el fraile el crucifijo,

Coge la ametralladora,

Se arremanga la sotana

Y nos deja ver la cola,

(cavernícola con miedo, 
con miedo y con hidrofobia),

sus pesetas fratricidas

gasta Ignacio de Loyola,

maúlla su escepticismo

de anciano Pío Baroja,

ríe el Borbón putrefacto

presintiendo una corona

y la Legión Extranjera

mata, incendia, estupra, roba...

España, la de hoy, cantarte

quiero con aire de copla.

España, la de hoy, España

de sí misma acusadora,

la del puño levantado,

la de alpargata y de boina

la que habla en la Pasionaria,

erguida musa española,

la valiente como un toro

que embiste, pero razona,

la España de hoy, la que anhela

ser una España de Europa,

la que con épico brío

dolor y sangre derrocha 
contra la España del feudo

contra la España gazmoña

del convento y del palacio,

cuevas pobladas de sombras,

de sombras que bien se nutren,

de sombras que se retozan...

España la de hoy, cantarte

quiero con aire de copla.

¿Muere un mundo?: ¡Nace un mundo!

De esta llameante discordia, más brava, más heroína,

más bella, más generosa;

secular y renovada,

joven y aleccionadora;

has de surgir para ejemplo

de proletarias victorias.

España de hoy, compañera

que te enrojeces de aurora,

España de hoy, la que vive,

España maestra y moza...

España la de hoy, cantarte

quiero con aire de copla. 
«La copla al servicio de la Revolución» (Raúl González Tuñón)

La rosa blindada. Homenaje a la insurrección de Asturias y otros poemas revolucionarios,

Buenos Aires, Federación Gráfica Bonaerense, 1936, p. 59-60

La copla al servicio de la Revolución

A Miguel Hernández.

Los toreros son monárquicos,

los frailes también lo son.

¿Y los mineros de Asturias?

¡Viva la revolución!

En Mieres nació mi abuelo,

mi abuela en Pola de Siero.

La capital de mi sangre

se debe llamar Oviedo.

Los moros llegan a Oviedo

-la que siempre estuvo verde-

matan a los españoles

y violan a sus mujeres.

Camarada, cómo arde 
la ceniza de los muertos.

De los muertos de la cuenca

que la del Tercio no vale.

En aguas e Covadonga

se bañan los Regulares.

Los señores en Mallorca

y los mineros en sangre

No cantes ni cante jondo

ni copla de Romancero.

Canta "La internacional"

que ya cambiaron los tiempos

Al vasco y al catalán,

al gallego y al murciano

dadle también un fusil.

El también es asturiano.

En Octubre no hay verbenas

que no son de la estación

Octubre quiere decir

¡viva la revolución! 
«Los Llanos» (Emile Verharen)

Traducción de Lucrecia Radyk, con la colaboración de Gustavo Fernández, a partir de «Les

Plaines», Les Campagnes hallucinées. Les Villes tentaculaires, Paris, Gallimard, 2010.

Los llanos

Bajo la tristeza y la angustia de los cielos

Las leguas

Se alejan hacia los llanos;

Bajo los cielos bajos

Cuyas nubes se arrastran,

Inmensamente, las leguas

Avanzan, allá.

Derechas sobre los rastrojos, las torres;

Y personas cansadas, a montones,

Que van de pueblo en pueblo.

Las personas errantes

Como el camino, tienen cien años;

Van de llano en llano,

Desde siempre, a través del tiempo;

Las preceden o las siguen

Carretas cuyos cortejos se desvían 
Hacia aldeas y callejones,

Carretas incesantes,

Gritando el lamentable grito,

De noche y de día,

De sus ejes hacia el infinito.

Es el llano, el llano

Inmensamente, hasta perder el aliento.

Pobres terrenos orlados con setos

Dividen su suelo cubierto de penas;

Pobres terrenos, pobres granjas,

Las puertas desvencijadas

Y los rastrojos, como mantos

Que el viento perfora a golpes de hacha.

En los alrededores, ni el trébol verde, ni la alfalfa enrojecida,

Ni lino, ni trigo, ni matas frondosas, ni brotes,

Desde hace tiempo, el árbol, partido por el rayo,

Se ciñe, en el umbral gastado,

Como una desgracia en efigie.

Es el llano, el Ilano pálido,

Interminablemente, siempre el mismo. 
Por encima, a menudo,

Ruge tan fuerte el viento

Que el cielo pareciera agrietarse

A golpes de puño

Del equinoccio.

Noviembre aúlla como un lobo,

Lamentable, por la noche loca.

Ramizas y hojas heladas

Pasan azotadas

Sobre los charcos, por las alamedas;

Y los grandes brazos de Cristos fúnebres,

En las esquinas, por las tinieblas,

Parecen crecer y de pronto partir.

En grito de horror, hacia el sol perdido.

Es el llano, el llano

Donde sólo vagan el miedo y la pena.

Los ríos se estancan o se secan

El oleaje sólo llega hasta las praderas,

Los enormes diques de turba,

Inútiles, arquean su curva.

Como el suelo, las aguas están muertas;

Entre las islas, en escolta 
Hacia el mar, donde las ensenadas aún se contemplan.

Hachas y martillos voraces

Descuartizan las osamentas

Putrefactas de viejos navíos.

Es el llano, el llano

Inmensamente, hasta perder el aliento,

Donde circulan por los caminos,

Entre la identidad

Los campos de duelo y de la pobreza,

Desesperanzas y miserias;

Es el llano, el llano

Que surcan bandadas inmensas

De pájaros gritando la muerte

En oleadas del cielo al Norte;

Es el llano, el llano

Opaco y largo como el odio,

El llano y el terruño sin fin

De un sol blanco como el hambre,

Donde, sobre el río solitario,

Gira en remolino todo el dolor de la tierra. 
«No podéis, no, prestar atención...» (Juan L. Ortiz)

Obra Completa, Santa Fe, UNL, 2010, p. 236-38

No podéis, no, prestar atención...

No podéis, no, prestar atención

a las bellezas, a las gracias que os rodean.

¿Las gracias?

Bajo la lluvia y el frío habréis de marchar, fuertes.

La lluvia sobre los jardines,

será una ironía, acaso, para vuestra hambre,

para vuestra impotencia actual de la gran dignidad

humana?

Las gasas móviles — ¿quién danza? — serán agujas finas

sobre la dura piel, aún sensible,

o una humedad toda vencedora

de lo más íntimo vuestro?

Una inundación gris sobre vuestras mujeres y vuestros hijos?

¿La tierra cruel sin lámpara y sin techo?

Y el sol, el sol, y la mañana

pura de rocío y de rosas,

y el mediodía perfecto y alto como un canto?

Y la tarde, la tarde,

meditación madura destacada 
del pensamiento activo del día,

o gracia descendiente como un vuelo que ordena

las frases locas de los pájaros

y las encendidas danzas de las horas,

hasta la paz final con la brisa oscura:

poder, dulce poder que armoniza todos los gestos!

No podéis, no, prestar atención,

ni menos comulgar con las bellezas

que os acompañan, sin embargo.

Apenas si el presentimiento

de un resplandor efímero

cuando la belleza os hiere.

Menos ahora, hermanos míos,

menos ahora.

La llamarada trágica de España

os llega

con un calor de angustia y de esperanza.

Duros estáis vosotros y es bueno que así sea ahora

en que el enemigo está activo por todo,

en que la lejana metralla despedaza

a las mujeres y los niños de vuestros compañeros.

Es tiempo de marchar todos unidos, fuertemente unidos, 
al ritmo de las canciones de vuestros poetas.

Fuertemente unidos, la mirada alerta,

aunque la mañana sea la primer mañana

y la tarde la estampa más vieja, más misteriosa del recuerdo

repentinamente surgida de las nieblas de la sangre.

Es tiempo de marchar fuertemente unidos

aunque seáis sensibles a los poderes desconocidos y encantadores.

“Dura la pupila que ve lejos", sí.

"Sujetar, no cortar, las alas del alma,

aunque éstas sean finas y sensibles,

para que los vuelos futuros sean más altos".

Es ésta, hermanos míos, "una prueba de alas".

“Las fuertes sólo serán capaces

de las travesías inauditas que exigirán los días".

Yo os iba, sin embargo, a invitar a mirar este cielo.

¡Qué cielo, hermanos míos, de anochecer de Abril!

El mundo vuelto todo hacia el puro resplandor

extraño, espiritual, místico, casi.

-iQué torpes las palabras para las presencias misteriosas y ardidas! —

El mundo vuelto todo hacia el milagro amarillo

en una tensión toda religiosa. 
Os iba a invitar por un minuto solo.

Pero recordé que vais acerados y ágiles hacia el porvenir

donde duermen bellezas nuevas y frescas que ya nos hacen signos

en la gravedad sonriente y flexible de vuestro sacrificio

de todos los minutos del día y de la noche,

en la fuerza creadora de vuestro anhelo disciplinado

que configurará la tierra y los cielos.

Pero recordé que vuestros pasos deben aplastar las violetas,

si ellos conducen a la comunión final,

desde la cual las tardes serán las fiestas máximas,

el delicado, silencioso espectáculo, la numerosa comunión callada

que ennoblecerá las noches de todos,

el pensamiento íntimo de todos,

los sueños más secretos, más secretos, de todos. 
Memorias de un provinciano (Fragmento) (Carlos Mastronardi)

Buenos Aires, Ediciones Culurales, 1967, p. 93-96

Creo que en la biblioteca vi por primera vez al poeta Juan L. Ortiz, que habría de ser uno de mis grandes amigos. Me superaba algo en edad y mucho en versación y acierto selectivo, pues tenía ya el gusto formado, de modo que podía leer con provecho a Taine, a Guyau y a Paul de Sain-Víctor cuando yo apenas salía de las novelas de capa y espada. Muchas noches abandonamos juntos ese ámbito apacible (me gustaba el olor a madera barnizada que tantas veces respiré en él), donde habíamos iniciado una conversación que, al cerrar la casa sus puertas, proseguíamos en la calle. A veces lo acompañaba hasta la suya, situada en un extremo del pueblo, a pocos pasos del río. Aún no había formado su hogar, de modo que vivía sólo, en una casa esquinera que parecía una atalaya y en la cual congregaba gatos y amigos. Su piedad franciscana excedía - y excede-, el estrecho ámbito humano, y ya en aquel tiempo recogía los pequeños animales abandonados o perdidos en los espinosos cercos de los suburbios. En esos años, sólo entregado a la naturaleza que lo rodeaba y a los libros que podía obtener, no pensaba publicar sus poemas, pero ya había escrito algunos con humilde y escondida delectación. Cedía muchas horas libres a la lectura y al río; de modo eventual, sin embargo, la pluma y el pincel lo atraían con parejo encanto. Fue retratista recio y excelente paisajista, pero la poesía acabó por identificarse con su vida. Desprovisto de colores y telas, con improvisados elementos de trabajo solía reproducir un rostro o detener en términos de arte una puesta de sol. En sus habitaciones de paredes rugosas y puertas con antiguos pasadores de hierro que nunca utilizó - confiaba en la honestidad de sus vecinos - vi algunos retratos que eran obra suya y que comportaban otros tantos homenajes a escritores de su dilección. Allí estaban Tolstoy, Gorki, Romain 
Rolland, Rafael Barret y creo que Barbusse. Si no recuerdo mal, eran retratos al carbón. El sol intruso - sobre aquella casa insular más imperioso- y los desniveles de la rudimentaria pared habían arqueado los cartones que presentaban esos rostros ilustres. Por otra parte, dichos trabajos respondían a una exigencia de su intimidad y de ningún modo forzaban el sentimiento admirativo de los otros. Nunca lo movió el afán de convertir sus emociones en las provechosas etapas de una carrera artística o literaria.

Sucinto como un junco, suave la voz, propenso a la contemplación y al silencio, desentendido de las rencillas locales y perdida la mirada en la lejanía, tanto su aspecto como sus hábitos causaban una especie de amable extrañeza. Sencillo en la palabra y en la ropa -su única coquetería era un sombrero de artista, un sombrero de ala tan ancha que debía quitárselo para trasponer algunas puertas - y totalmente incapacitado para la codicia, estos insólitos atributos impedían clasificarlo o definirlo según las pautas corrientes. En vez de salir en busca de otro empleo - tenía uno muy modesto- buscaba el recogimiento y pedía el éxtasis a las aguas del río vecino y a los atardeceres silvestres. No escrutaba sino que se integraba en la naturaleza: era un gajo más de aquellos árboles ribereños. Los cielos y los campos que para los demás son lluvia y pasto, generaban en él estados mágicos. Frecuentaba la costa frondosa, donde muchas veces lo sorprendí como embelesado y ausente, los ojos agradecidos en el horizonte. Esos hábitos singulares, y la fuerte impresión de irrealidad que dejaba en la gente normalmente ávida, no lo privaban de amigos. En mis ya numerosos años no he conocido hombre más bueno ni más comprensivo. Mantenía trato afectuoso con sus vecinos, casi todos ellos "boteros" y pescadores. En ese medio, donde el porvenir no podía ser sino idéntico al ayer, pues todo se reducía a seguir tirando, no causaba perplejidad ni extrañeza, pero las personas acomodadas o por acomodarse, sólo atentas a los bienes concretos, lo apreciaban sin entenderlo. Como nunca lo vieron arrojarse 
sobre las cosas con voluntad posesiva, su carencia de avidez les traía asombro. Quizás lo juzgaban un excéntrico o un hereje social, ya que sólo podían medirlo con sus habituales esquemas. 


\section{Bibliografía}

AAVV. Capítulo 105. La historia de la literatura argentina. Buenos Aires: Centro Editor de América Latina, 1981.

—. Contra. La revista de los francotiradores. Bernal: Universidad Nacional de Quilmes, 2005.

—. Contra. La revista de los francotiradores. Buenos Aires: Universidad Nacional de Quilmes, 2005.

-. Crisis económica, avance del Estado e incentidumbre política (1930-1943). Tomo VIII de la Nueva Historia Argentina. Ed. Alejandro Cattaruzza. Buenos Aires: Sudamericana, 2001.

—. Diccionario Biográfico de la Izquierda Argentina, de los anarquistas a la "nueva izquierda" (18701976). Buenos Aires: Emecé, 2007.

—. «Dossier Juanele.» Diario de poesía (1986): 11-23.

-. El antifascismo argentino. Antología y documentos. Ed. Andrés Bisso y Horacio Tarcus. Buenos Aires: Buenos Libros y CEDINCI, 2007.

- El pensamiento alternativo en la Argentina del siglo XX. Tomo II. Obrerismo, vanguardia, justicia social (1930-1960). Ed. Hugo E. Biagini y Arturo A. Roig. Buenos Aires: Biblos, 2006.

—. Islote municipal. Parana : EDUNER, 2015.

—. Los poetas del 40. Ed. Alfredo Veiravé. Buenos Aires: CEAL, 1968.

—. Los que fueron a España. Buenos Aires: Editorial Jorge Álvarez, 1966.

—. Polémica sobre el realismo. Ed. Ricardo Piglia. Buenos Aires: Tiempo contemporáneo, 1972.

—. Por Tuñón. . Buenos Aires: Ediciones del Centro Cultural de la Cooperación Floreal Gorini, s.f.

—. Prensa y Guerra Civil Española. Periódicos de España e Iberoamerica. Madrid: AECI, 2006.

—. Términos críticos de la sociología de la cultura. Ed. Carlos Altamirano. Buenos Aires: Paidos, 2008.

—. Testigos de China. Ed. Juana Bignozzi. Buenos Aires: Carlos Pérez Editor, 1968.

—. Una poesía del futuro. Conversaciones con Juan L. Ortiz. Ed. Osvaldo Aguirre. Buenos Aires: Mansalva, 2008.

—. Yrigoyen entre Borges y Arlt (1916-1930): literatura argentina siglo XX. Ed. Graciela Montaldo y David Viñas. Buenos Aires: Paradiso, 2006.

Abelardo Ramos, Jorge. Crisis y resurrección de la literatura argentina. Buenos Aires: Editorial Indoamericana, 1954.

Adorno, T. Notas sobre literatura. Madrid: Akal, 2006.

—. Teoría estética. Madrid: Akal, 2004. 
Agosti, Héctor P. Anibal Ponce. Memoria y presencia. Buenos Aires: Editorial Cartago, 1974.

-. Defensa del realismo. Montevideo: Ediciones Pueblos Unidos Ltda., 1945.

-. El hombre prisionero. Buenos Aires: Claridad, 1938.

—. La milicia literaria. Buenos Aires: Sílaba, 1969.

—. «La misión del escritor.» Nueva Gaceta (1942).

—. Para una política de la cultura. Buenos Aires: Sílaba, 1969.

—. Para una política de la cultura. Buenos Aires: Sílaba, 1969.

«Agrupación Claridad.» Justicia 27 de Julio de 1932: sn. Papel.

Altamirano, Carlos. Peronismo y cultura de izquierda. Buenos Aires: Siglo XXI, 2011.

Alzari, Agustín. La internacional entrerriana. Rosario : Editorial Municipal de Rosario, 2012.

Anonimo. «Recepción de La rama hacia el este.» Claridad 344 (1940): 447.

Ansolabehere, Pablo. Literatura y anarquismo en Argentina (1879-1919). Rosario: Beatriz Viterbo, 2011.

Arévalo, Oscar. El partido comunista argentino. Buenos Aires: Centro Editori de América Latina, 1983.

Aricó, José M. La cola del diablo. Buenos Aires: Siglo XXI Editores, 2005.

Aron, Paul. Les Écrivain Belges et le Socialisme (1880-1913). Bruselas: Éditions Labor, 1995.

Barrandeguy, Emma. Habitaciones. Buenos Aires: Catálogos, 2002.

-. Poesía Completa. Córdoba: Alción, 2006.

-. «Testimonio.» Xul (1997): 42-43.

Bayley, Edgar. Realidad interna y funcion de la poesía. Rosario: Editorial Biblioteca Popular Constancio C. Vigil, 1966.

Binns, Niall. La llamada de España. Escritores extranjeros en la guerra civil. Madrid: Montesinos, 2004.

-. Voluntarios con gafas. Escritores extranjeros en la Guerra Civil. Madrid: Mare Nostrum, 2009.

Bourdieu, P. Campo del poder y campo intelectual. Buenos Aires: Folio Ediciones, 1971.

Brenan, Gerald. El laberinto español. Antecedentes sociales y políticos de la Guerra Civil. Madrid: Biblioteca de la República, 2011.

Cane, James. «"Unity for the Defense of Culture": The AIAPE and the Cultural Politics of Argentine.» The Hispanic American Historical Review 77.3 (1977): 443-482. 
Cattaruzza, Alejandro. «Visiones del pasado y tradiciones nacionales en el Partido Comunista Argentino (ca. 1925-1950).» A contracorriente 5.2 (2008): 169-195.

Cheresky, Isidoro. "Sindicatos y fuerzas políticas en la Argentina preperonista (1930-1943).» Boletín de Estudios Latinoamericanos y del Caribe (1981): 5-42.

Christophe, Lucien. Émile Verhaeren. Paris: Editions Universitaires, 1955.

Ciria, Alberto. Partidos y poder en la Argentina Moderna (1930-1960). Buenos Aires: Hyspamérica, 1986.

Dalmaroni, Miguel. La investigación literaria. Problemas iniciales de una práctica. Santa Fe: Universidad Nacional del Litoral, 2009.

Darío, Rubén. Obras Completas. Buenos Aires: Anaconda, 1952.

del Barco, Oscar. Juan L. Ortiz. Poesía y Ética. Córdoba: Alción Editora, 1996.

Di Tella, Torcuato S. «La Unión Obrera Textil, 1930-1945.» Desarrollo Economico 33.129 (1993): 109136.

Dujovne Ortiz, Alicia. «Juanele Ortiz revisitado.» 04 de Junio de 2006. 11 de 10 de 2015. <http://www.lanacion.com.ar/811200-juanele-ortiz-revisitado>.

Ferrer, Christian. Cabezas de tormenta. Buenos Aires: Utopía Libertaria, 2006.

Freidemberg, Daniel. «Reververaciones, llamados, misterios: Juan L. Ortiz.» Inti (2001): 79-98.

García Helder, Daniel. «Juan L. Ortiz: un léxico, un sistema, una clave.» Ortiz, Juan L. Obra completa. Santa Fe: Universidad Nacional del Litoral, 2005. 144.

Gilbert, Isidoro. La Fede, alistándose para la revolución. La federación juvenil comunista 1921-2005. Buenos Aires: Sudamericana, 2009.

Gilbert, Jorge O. y Elisa D. Balsechi. Voces del Sindicalismo Enterriano. Memorias de la Unión Obrera Departamental de Concepción del Uruguay (1918-1943) . Buenos Aires: Ediciones del Zorrito, 2008.

Giordano, Carlos R. «El caso Juan L. Ortiz.» Giordano, Carlos R. Capítulo, la historia de la literatura argentina № 50, La poesía social después de Boedo. Buenos Aires: Centro Editor de América Latina, 1967. 1193.

Gola, Hugo. «Introducción.» Ortiz, Juan L. En el aura del sauce. Rosario: Editorial Biblioteca, 1970. 11.

Goldfarb, Marcos. «Neruda: El poeta comunista.» Revista de Critica Literaria Latinoamericana (1985): 101-107.

González Tuñón, Raúl. «Agosti.» Claridad 312 (1937): sn.

-. La literatura resplandeciente. Buenos Aires: Editorial Boedo-Silbalba, 1976. 
-. La muerte en Madrid. Las puertas del fuego. 8 documentos de hoy. Rosario: Beatriz Viterbo Editora, 2011.

-. La rosa blindada. Homenaje a la insurrección de Asturias y otros poemas revolucionarios. Buenos Aires: Federación Gráfica Bonaerense, 1936.

-. «Las brigadas de choque.» Contra 4 (1933).

Gramuglio, María Teresa. «El realismo y sus destiempos en la literatura argentina.» Jitrik, Noé. Historia crítica de la literatura argentina. Vol. VI. Buenos Aires: Emece, 2002.

-. «Juan L. Ortiz, maestro secreto de la poesía argentina.» Cuadernos Hispanoamericanos (2004): 45-65.

-. Nacionalismo y cosmopolitismo en la literatura argentina. Rosario: Editorial Municipal de Rosario, 2013.

Halperin Donghi, Tulio. La argentina y la tormenta del mundo. Ideas e ideologías entre 1930 y 1945. Buenos Aires: Siglo XXI Editores, 2004.

—. La república imposible (1930-1945). Buenos Aires: Ariel, 2004.

Hobsbawm, Eric J. "Socialism and the Avantgarde in the Period of the Second International.» Le Moumevent social 111 (1980).

Horvath, Ricardo. La trama secreta de la radiofonía argentina. Buenos Aires: Ediciones Unidad, 1986. Hugh, Thomas. La guerra civil española. París: Ruedo Ibérico, 1973.

Ibañez, Francisco M. Toponímia de Entre Ríos. La tierra, el hombre y los hechos. Santa Fe: Ediciones Colmegna, 1971.

Ingenieros, José. La evolución de las ideas argentinas. Vol. I. Buenos Aires: El ateneo, 1951.

Juárez, Laura. "Arlt y la polémica sobre la novela.» Revista Iberoamericana LXXIV.222 (2008).

Kamenszain, Tamara. «Juan L Ortiz: las arrugas son los ríos.» Clarín 7 de junio de 1972.

Kohan, Néstor. «Héctor P. Agosti, introductor de Gramsci en américa latina.» Le monde diplomatic (2004).

Kordon, Bernardo. Un horizonte de cemento. Buenos Aires: Ediciones AIAPE, 1940.

Lafleur, René, Sergio Provenzano y Fernando Alonso. Las revistas literarias argentinas (1896-1967). Buenos Aires: CEAL, 1962.

Lamborghini, Leónidas. «El gauchesco como arte bufo.» (comp.), Julio Schvartzman. Historia crítica de la literatura argentina. La lucha de los lenguajes. Volumen II. Vol. II. Buenos Aires: Emece, 2003.

Larra, Raúl. Con pelos y señales. Buenos Aires: Editorial Futuro, 1986. 
-. Etcetera. Buenos Aires: Ánfora, 1982.

Lifschitz, Laura. «Realismo y crítica. La función del arte en la propuesta de Héctor P. Agosti.» (comp), Guillermo Korn. El peronismo clásico (1945-1955) Descamisados, gorilas y contreras, Literatura argentina siglo XX. Tomo 4. Buenos Aires: Paradiso, 2007.

López de Molina. «Barrio de la boca.» Claridad (1930): sn.

Manauta, Juan José. «Testimonio.» Xul (1997): 44-46.

Martínez, David. Poesía Argentina Actual (1930-1960). Buenos Aires: Ediciones Culturales Argentinas, 1961.

Marx, K. y Engels, F. Escritos sobre literatura. Buenos Aires: Colihue, 2003.

Mastronardi, Carlos. "Carta a Cesar Tiempo. 15 de Septiembre de 1932.» Gualeguay: Biblioteca Nacional - Archivo «Cesar Tiempo». CT 807, 15 de Septiembre de 1932.

-. «Carta a Cesar Tiempo. 16 de junio 1935.» Gualeguay: Biblioteca Nacional - Archivo «Cesar Tiempo» - CT 242, 19 de Junio de 1935.

-. "Carta a Cesar Tiempo. 24 de febrero de 1932.» Gualeguay: Biblioteca Nacional - Archivo "Cesar Tiempo». (CT 1898), 24 de febrero de 1932.

Mastronardi, Carlos. «Introducción.» Pedroni, José. Poesía Completa. Rosario: Editorial Biblioteca, 1969.

-. Memorias de un provinciano. Buenos Aires: Ediciones Culturales Argentinas, 1967.

-. Memorias de un provinciano. Buenos Aires: Ediciones Culturales, 1967.

-. Obra completa. Vol. II. Santa Fe: Universidad Nacional del Litoral, 2010.

Medina Onrubia, Salvadora. «A caballo, a pie, a nado y en bote.» Fray Mocho (1914).

Navarro Tomás, Tomás. Manual de pronunciación española. Madrid: Publicación de la revista de Filología, 1950.

-. Métrica española. Barcelona: Editorial Labor, 1995.

Neruda, Pablo. Tercera residencia (1935-1945). Buenos Aires: Losada, 1947.

Oldrich, Belic. Verso español y verso europeo. Introducción a la teoría del verso españolen el contexto europeo. Santafé de Bogotá: Publicaciones del Instituto Caro y Cuervo, 1999.

Ortiz, Evar. «Testimonio.» Xul 12 (1997): 41.

Ortiz, Juan L. «22 de Junio (A los poetas de la rosa y de la mariposa).» Nueva Gaceta (1942): 7.

Ortiz, Juan L. «A los poetas españoles.» Valdés., Ildefonso Pereda. Cancionero de la Guerra civil española. Montevideo: Comité Pro-Defensa de la República Española, 1937. 
—. «Autobiografía.» Paraná (1941).

-. «Carta a Cesar Tiempo (CT807).» Gualeguay, s.f.

-. «Carta a Cesar Tiempo. 14 de abril de 1930.» Gualeguay: Biblioteca Nacional - Archivo «Cesar Tiempo». CT 605, 14 de Abril de 1930.

-. «Carta a Cesar Tiempo. 30 de octubre de 1937.» Gualeguay: Biblioteca Nacional - Archivo «Cesar Tiempo». СT 4500, 30 de octubre de 1937.

—. "Carta a José Potogalo. 16 de marzo de 1939.» Gualeguay: Archivo familiar José Ananía, 16 de marzo de 1939.

-. El alba sube. Buenos Aires: Ediciones Rumbo, 1937.

-. El Gualeguay. Rosario: Beatriz Viterbo, 2005.

-. El junco y la corriente. Ed. Francisco Bitar. Paraná;Santa Fe: UNL y EDUNER, 2013.

—. «El paisaje en los últimos poetas entrerrianos.» Davar (1948): sn.

-. En el aura del sauce. Vol. 1. Rosario: Editorial Biblioteca, 1970. 2 vols.

-. Estas primeras tardes y otros poemas para la revolución. Ed. Agustín Alzari. Rosario: Serapis, 2012.

—. Juanele.Poemas. Buenos Aires: Carlos Pérez Editor, 1969.

—. «La noche pálida tiembla.» Nueva Gaceta 1 (1941): 2.

-. La rama hacia el este. Buenos Aires: Ediciones AIAPE, 1940.

—. «Los mundos unidos (El hospital Palma).» Nueva Gaceta 14 (1942): 2.

—. «Mayo y la inteligencia argentina.» El Litoral 1 de mayo de 1942.

-. Obra Completa. Santa Fe: Universidad Nacional del Litoral, 2005.

—. «Poemas.» Claridad 205 (1930): SN.

Pasolini, Ricardo. Antifascismo y comunismo. Avatares de la intelectualidad de izquierda en la Argentina, 1945-1955. En prensa, s.f.

-. La utopía de Prometeo. Juan Antonio Salceda, del antifascismo al comunismo. Tandil: Universidad Nacional del Centro de la Provincia de Buenos Aires., 2007.

Paucke, Florian. Hacia allá y para acá. Santa Fe: Espacio Santafesino Ediciones, 2010.

Paz, Octavio. El arco y la lira. México: Fondo de Cultura Económica, 1956.

-. Octavio Paz en España, 1937. Antología y prólogo de Dnubio Torres Fierro. México: Fondo de Cultura Económica, 2007. 
Pedroni, José. Obra Poética. Rosario: Editorial Biblioteca, 1969.

Piemonte, Víctor Augusto. «El realismo socialista, la Tercera Internacional y el giro político y cultural en el comunismo argentino.» VII Jornadas de Sociología de la UNLP, 5 al 7 de diciembre de 2012, La Plata, Argentina. En Memoria Académica. La Plata: UNLP, 07 de 12 de 12. En linea. 15 de 10 de 2015.

<http://www.memoria.fahce.unlp.edu.ar/trab_eventos/ev.2189/ev.2189.pdf>.

Piemonte, Víctor Augusto. «La política cultural del Partido Comunista de la Argentina durante el tercer período y el problema de su autonomía respecto del Partido Comunista de la Unión Soviética.» Revista Izquierdas 15 (2013): 1-33.

Pisarello, Gerardo. En el recuerdo de los años. Buenos Aires: Editorial Ánfora, 1983.

Ponce, Anibal. Apuntes de viaje y Diario íntimo de una adolescente. Buenos Aires: J. Héctor Matera Editor, 1956.

-. El viento del mundo. . Buenos Aires: Futuro, 1963.

Portogalo, José. Canción para el día sin miedo. Buenos Aires: AIAPE, 1939.

-. Poemas (1933-1955). Buenos Aires: D’Accurzio Impresor, 1961.

-. Tumulto. Rosario: Serapis, 2012 [1935].

-. Tumulto. Buenos Aires: Imán, 1935.

Prieto, Martín. Breve historia de la literatura argentina. Buenos Aires: Aguilar, Altea, Taurus, Alfaguara, 2006.

Prieto, Martín. «En el aura de sauce en el centro de una historia de la poesía Argentina.» Ortiz, Juan L. Obra completa. Santa Fe: Universidad Nacional del Litoral, 2005. 117.

—. «Raúl González Tuñón, la vanguardia popular.» 21 de 10 de 2011. Revista Ñ. 29 de Septiembre de 2015. <http://www.revistaenie.clarin.com/literatura/poesia/Raul_Gonzalez_Tunon_la_vanguardia_popular_0_577142289.html>.

Puiggros, Rodolfo. De la colonia a la revolución. Buenos Aires: AIAPE, 1940.

-. Historia crítica de los partidos políticos argentinos. Buenos Aires: Argumentos, 1956.

Rama, Ángel. La ciudad letrada. Hanover: Ediciones del Norte, 1984.

—. La crítica de la Cultura en América Latina. Caracas: Biblioteca Ayacucho, 1985.

—. Las máscaras democráticas del Modernismo. Montevideo: Fundación Ángel Rama, 1985.

-. Literatura y clase social. México: Folios Ediciones, 1984.

-. Rubén Darío y el modernismo: circunstancias socio-económicas de un arte americano. Caracas: Ediciones de la Universidad Central de Venezuela, 1970. 
-. Transculturación narrativa en América Latina. México: Siglo XXI, 1984.

Ramos, Jorge Abelardo. Breve historia de las izquierdas en la argentina. Vol. II. Buenos Aires: Claridad, 1990. II vols.

Rojas, Ricardo. Historia de la Literatura Argentina, ensayo filosófico sobre la evolución de la cultura en el Plata. Buenos Aires: Editorial Guillermo Kraft., 1960.

Romano, E. «Qué es eso de una generación del 40.» Cuadernos de poesía (1966).

Rosa, Claudia. «Entre Gualeguay y Paraná.» Villanueva, Amaro. Obras completas. Parana: UNER, 2010.

Rosa, José María. «El gobierno de E. Ríos engaña al país diciendo que hay libertad de trabajo y no existen agrupaciones extremistas.» La voz de Entre Ríos 27 de febrero de 1937.

Saer, Juan José. El río sin orillas. Buenos Aires: Alianza Singular, 1991.

Saer, Juan José. «Juan.» Ortiz, Juan L. En el aura del sauce. Antología. Santa Fe: Universidad Nacional del Litoral, 1989. 7-12.

Saitta, Silvia. «Polémicas ideológicas, debates literarios en Contra. La revista de los francotiradores.» AAVV. Contra. La revista de los francotiradores. Bernal: Universidad Nacional de Quilmes, 2005.

Salceda, Juan Antonio. Anibal Ponce y el pensamiento de Mayo. Buenos Aires: Editorial Lautaro, 1957.

Salinas, Pedro. La poesía de Rubén Darío. Barcelona: Pedro Salinas, 2005.

Sanchez Sorondo, Matías G. Represión del comunismo. Proyecto de ley, informe y antecedentes. Buenos Aires: Imprenta del congreso nacional, 1940.

Sarlo, Beatriz y Carlos Altamirano. Conceptos de sociología literaria. Buenos Aires: Ceal, 1990.

Serfaty, Carlos. «Reseña de El alba sube.» Unidad 2.1 (1937): 16.

Serra, Edelweis. El cosmos de la palabra. Mensaje poético y estilo de Juan L. Ortiz. Buenos Aires: Noe, 1976.

Steiner, George. Lenguaje y silencio. México: Gedisa Editorial, 1990.

Stirner, Max. El Único y su propiedad. Buenos Aires: Libros de Anarres, 2003.

Tcherkaski, José. Un pensamiento luminoso. Conversaciones con Juan L. Ortiz. Buenos Aires: Galerna, 1999.

Tiempo, César. «José Portogalo, el poeta de la luz.» El Jabalí (2001): 37-38.

-. Manos de obra. Buenos Aires: Corregidor, 1980.

Todorov, Tzvetan. Teoria de la literatura de los formalistas rusos. Buenos Aires: Siglo XXI, 2004. 
Torre, Juan Carlos. La vieja guardia sindical y Perón. Sobre los orígenes del peronismo. Buenos Aires: RyR, 2011.

Troise, Emilio. «Solicitada en apoyo a José Portogalo.» Unidad (1937).

Unidad. «Frentes Populares.» Unidad 1 (1936): 15.

Urondo, Francisco. «Juan L. Ortiz. El poeta que ignoraron.» La opinión 4 de Julio de 1971.

Vairavé, Alfredo. «Estudio Preliminar para una antología de la Obra Poética de Juan Ortiz.» Universidad 63 (1965).

Valery, Paul. Teoría poética y estética. Madrid: Editora Nacional, 2002.

Vallejo, César. El arte y la revolución. Lima: Mosca Azul Editores, 1973.

—. Poesía completa. Buenos Aires: La Página, 2006.

—. Rusia en 1931, reflexiones al pie del kremlin. Lima: Editora Perú Nuevo, 1959.

Veiravé, Alfredo. Juan L. Ortiz. La experiencia poética. Buenos Aires: Carlos Lohlé, 1984.

Verhaeren, Emile. Les Campagnes hallucinées. Les Villes tentaculaires. Paris: Gallimard, 2010.

Vico, Humberto P. Historia de Gualeguay. 1910-1940. Santa Fe: Ediciones Colmegna, 1976.

—. Historia de Gualeguay. 1940-1955. Gualeguay: Ediciones Entre Ríos, 2004.

-. Historia de Gualeguay. Desde sus origenes a 1910. Vol. I. Santa Fe: Librería y editorial Colmegna S.A., 1976. III vols.

Villanueva, Amaro. «Carta a Cesar Tiempo. 12 de noviembre de 1937.» Paraná: Biblioteca Nacional Archivo «Cesar Tiempo». CT 4968, 12 de noviembre de 1937.

—. «Carta a Cesar Tiempo. 21 de octubre de 1937.» Paraná: Biblioteca Nacional - Archivo «Cesar Tiempo». CT 4600, 21 de Octubre de 1937.

—. «Carta a Cesar Tiempo. 21 de octubre de 1937.» Paraná: Biblioteca Naciona - Archivo «Cesar Tiempo». CT 4600, 21 de octubre de 1937.

—. Crítica y pico (Plana de Hernández) . Santa Fe: Ediciones Colmegna, 1945.

—. Obras Completas. Paraná: EDUNER, 2010.

Viñas, David. Literatura argentina y política. Tomo I. De los jacobinos porteños a la bohemia anarquista. Buenos Aires: Santiago Arcos, 2005.

-. Literatura argentina y política. Tomo II. De Lugones a Walsh. Buenos Aires: Santiago Arcos editor, 2005.

Williams, R. Marxismo y literatura. Barcelona: Península, 2000.

Yanover, H. Raúl González Tuñón. Buenos Aires: Ediciones Culturales Argentinas, 1962. 
Yunque, Álvaro. Anibal Ponce o los deberes de la inteligencia. Buenos Aires: Editorial Futuro, 1958.

—. España: 1936. Buenos Aires: Grabo, 1937.

-. La literatura social en la Argentina . Buenos Aires: Claridad, 1941.

-. Poetas sociales de la Argentina (1810-1943). Vol. II. Buenos Aires: Editorial Futuro, 1943.

—. Síntesis histórica de la Literatura Argentina. Buenos Aires: Claridad, 1957. 